
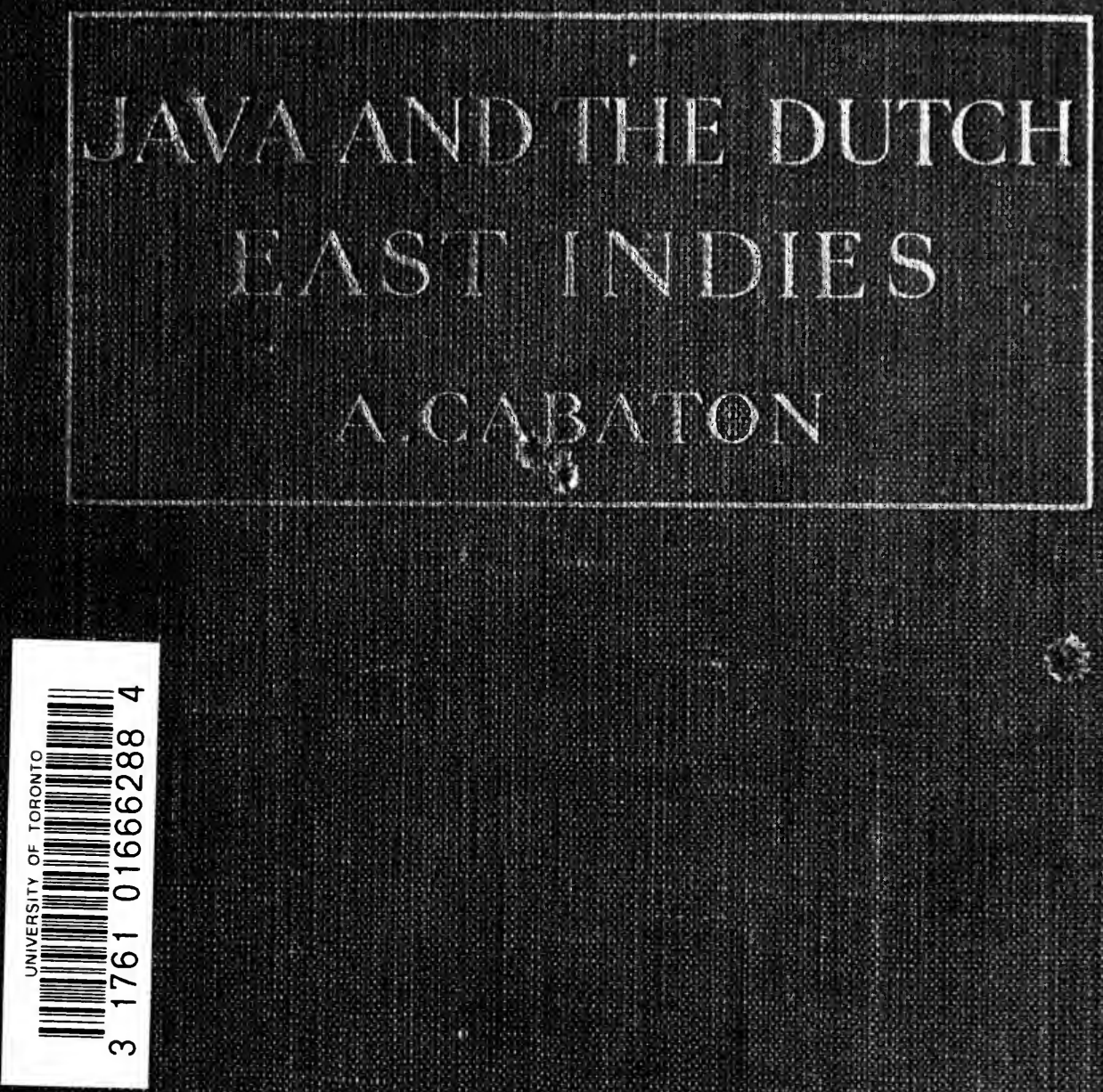


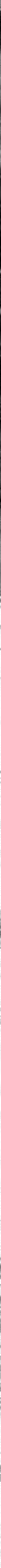




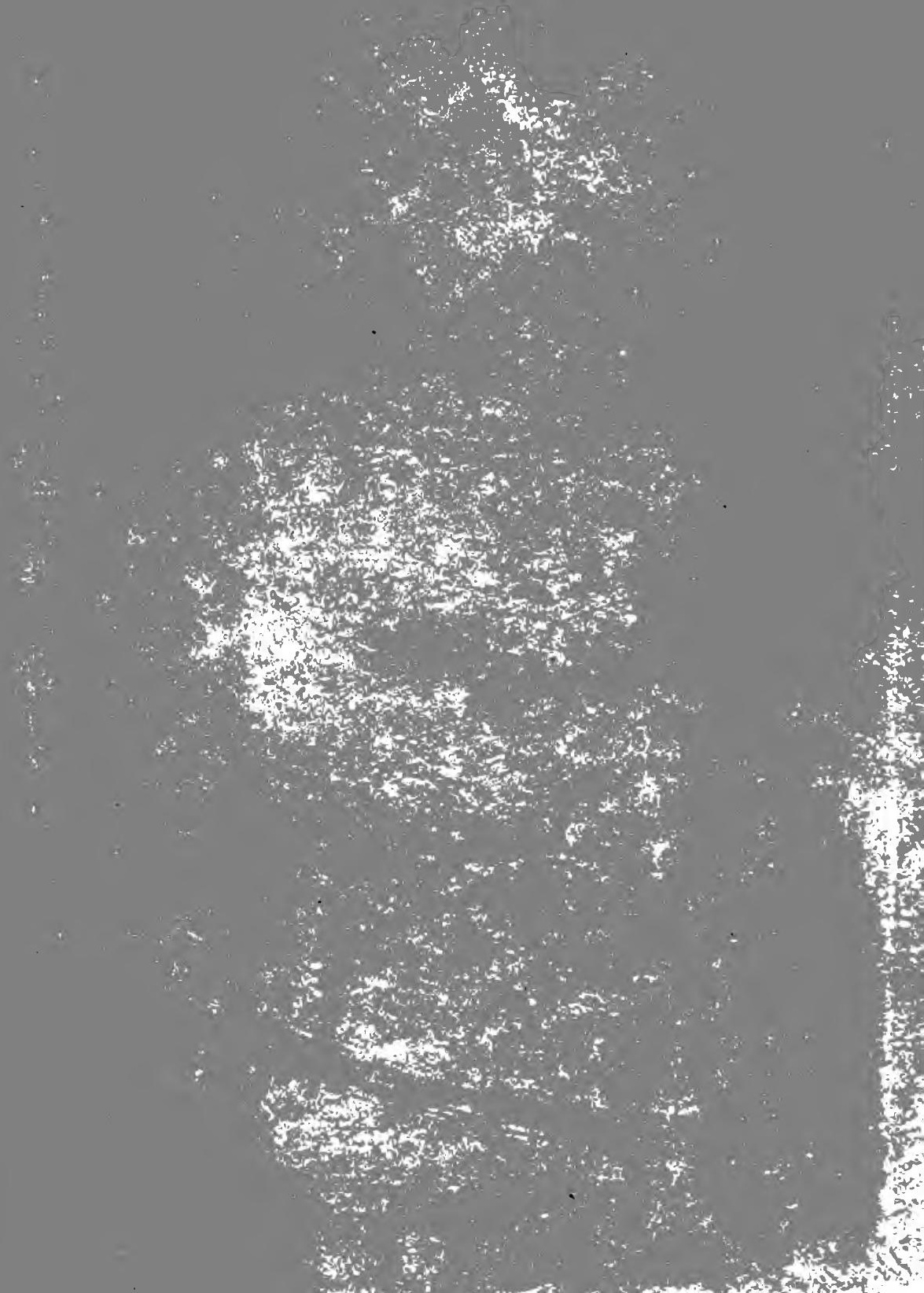




JAVA, SUMATRA, AND THE OTHER ISLANDS OF THE DUTCH EAST INDIES 

HAS.

GII36j

\section{JAVA, SUMATRA, AND THE OTHER ISLANDS of the DUTCH EAST INDIES}

By A. CABATON

TRANSLATED AND WITH A

PREFACE BY BERNARD MIALL

WITH A MAP AND 47 ILLUSTRATIONS

T. FISHER UNW IN

LONDON : ADELPHI TERRACE

LEIPSIC : INSELSTRASSE 20 
(All rights reserved.) 


\title{
CON'TEN'TS
}

\author{
CHAPTER I
}

\section{Historical Sketch}

I. The lost continent of the Pacific.-The significance of coral. - The old theory of the Asiatic irruption.-The new theory of the Polynesian migration.-Both anthropology and philology unreliable.-Probable origin of the Malays. - Traces of their passage in India.-Two languages. - The Hindu or Buddhist invasion.-Adjih Saka.-The nomadic legend.-Its probable interpretation.-Buddhist missions.-Immigration in bulk.Javanese chronicles.-Lack of political cohesion.-Was the Javanese civilisation a high one ?-Monuments.-The Hindu dynasties. - The Arab missionaries. - Demak. - The Arab warrior priests, and the fall of the Hindu Empire.-II. Arrival of the Europeans.-The Portuguese, Dutch, French, and English.-III. Sir Stamford Raffles and English rule.Recent developments.-Education and future prospects.

\section{CHAPTER II}

\section{Generalities}

I. The importance, area, and population of the Dutch East Indies.-II. Administrative divisions of the Dutch East Indies, and the best method of studying them.-III. European, and, in particular, Dutch intervention, in the East Indies.-IV. Physical characteristics of the Archipelago.-V. The races which inhabit it.-VI. The principal languages spoken; and which must be learned by the European settling in the Indies.

\section{CHAPTER III}

\section{Java and Madura: Physical Geography}

I. Their shape.-II. Their geological constitution and orographical aspect.-III. Streams and rivers of Java and Madura ; 
their qualities as alluvial agents, and their insufficiency as waterways ; their influence upon the coast-line and the harbours.IV. The climate: its stability.-V. The Javanese flora.-VI. The Javanese fauna.

\section{CHAPTER IV}

\section{Administrative Divisions of Java}

I.-The seventeen Residencies.-The western Residencies: Bantam, Batavia, Cheribon, the Preangers.-II. The central Residencies: Pekalongan, Samarang, Banjumas, Kedu.-III. Kedu and Boro-Budur.-IV. The Vorstenlanden or Principalities, Surakarta and Djokjakarta.-V. Rembang, Madiun. -VI. The Residencies of the East : Surabaja, Kediri, Pasuruan, Besuki, and Madura.

\section{CHAPTER V}

\section{The Natives of Java}

I. Distribution of the native element in Java : the Sundanese and Madurese compared with the Javanese.-II. The Javanese. -III. The Javanese house and village.-IV. The family and marriage.-V. Daily occupations : agricultural labour, hunting, and fishing.-VI. The batik industry: Javanese clothing.VII. The love of pleasure, and the means of satisfying it : betelnut, tobacco, opium, and hemp ; cock-fighting and gambling.VIII. Failings with which Europeans reproach the Javanese, nearly all of which have some historic excuse.

\section{CHAPTER VI}

\section{The Javanese Mind}

I. The religious question in Java is involved in the historic evolution of the masses.-The religion of Java is a sincere Islamism, modified by the survivals of earlier cults; tolerant and kindly, like the character of the nation.-II. How the Dutch Indies escaped Christianity. - III. The problem of education in Java; its various phases since the Dutch occupation.-IV. The awakening of the Javanese people and their leaders ; their claims. 


\section{CHAPTER VII}

\section{The Oriental Foreign Element}

I. The Oriental foreign element in Java and Madura: the Japanese, Arabs, and Chinese.-The Japanese are the latest arrivals, and the least numerous, but also the best treated.-II. The Arabs : the religious and economic danger represented by the Arab element in the Dutch Indies.-III. The Chinese : their numbers, their activity, their wealth.-Why they are considered detrimental to the political and economic power of the rulers, and the morality and prosperity of the native.-IV. The various solutions of the problem.-Their injustice, or insufficiency, or the impossibility of applying them.-The only remedy is to educate the Javanese so that they may take their place as loyal collaborators and agents of the administration and the European industries.

\section{CHAPTER VIII}

Europeans in Java

I. The three aspects of the European element in the Dutch Indies : army, colonisation, bureaucracy.-The army.-II. The colonists : foreigners, and why so few settle in Java.-The French colony.-III. The Dutch colony.-Its relation with the State and the natives: despite the vast area of the plantations, there are few private freeholds; the planter is the tenant of the State or of the natives; sometimes of both together.-IV. His life ; his house, furniture, and costume ; his food, servants, and amusements. $-V$. The instability of European families in Java ; why they do not settle there without thought of return.-VI. The half-breeds.

\section{CHAPTER IX}

\section{The Administration in Java}

I. The important position of the European officials in Java.Their restricted numbers are due to the form of government which obtains in the Dutch East Indies : the Dutch govern the natives through their own chiefs.--II. Relations between the native and European administrations. - III. The hierarchy, privileges, and importance of the European officials.-IV. Complaints against the officials made by colonists and natives. 


\section{CHAPTER $\mathrm{X}$}

\section{The Products of Java}

I. The various phases of the economic history of Java under Dutch rule.-II. The Van den Bosch or "forced cultivation" system.-III. The help given by the State to free labour. The Botanical Institute at Buitenzorg.-IV. Native property in land. V. Native crops : rice, coco-palms, areca- and betel-nuts.-VI. Bamboo ; bamboo huts.

\section{CHAPTER XI}

Agriculture : Various Crops.

I. Coffee. - II. Sugar-cane. - III. Tobacco. - IV. Tea. - V. Quinine.-VI. Indigo.-VII. Lesser crops : pepper, cinnamon, cotton, \&c.

\section{CHAPTER XII}

\section{Forests and Mines. Industry. Commerce .}

I. The forests of djati and of "natural woods."-II. The mines of Java; the mining system; petroleum. - III. Salt. - IV. Industries : their character; the industrial future of Java.-V. Institutions of credit and thrift.-VI. Internal trade and the means of transport and communication : roads, railways, rivers; steamer services between the various islands of the Archipelago.-The merchant marine of the Archipelago.-VII. Post and telegraphs. - VIII. Weights and measures.-The monetary system.-IX. The export trade ; customs ; transport.

\section{CHAPTER XIII}

The Outer Possessions (Buitenbezittingen). Sumatra AND the Archipelago of Riouw Lingga.

I. The various divisions of the "Outer Possessions," and the importance of Sumatra.-II. The dimensions, physical aspect, and coast-line of Sumatra.-III. The rivers and the sea-coast of Sumatra.-IV. The climate, flora, and fauna.- V. The native races : their origin, beliefs, and manners.-VI. The principal languages; the most useful language for the visitor to or inhabitant of Sumatra. 


\section{CHAPTER XIV}

\section{The Political and Economic Condition of Sumatra} AND the ARchipelago of Riouw Lingga • • 283

I. The Dutch have been hampered by certain European Powers and certain of the races of Sumatra in their endeavour to establish the power of Holland in Sumatra.-II. The present administrative divisions of Sumatra.-The principal towns and their future.-III. Economic value of Sumatra: the wealth of its natural resources.-IV. How far the natives have exploited the natural resources. $-V$. How far the Europeans have done so: the mines.-VI. Coffee and tobacco; spices.-VII. The means of communication with Sumatra : railways, packetboats.-The means of communication must be greatly enlarged before the island can be pacified and its wealth developed.

\section{CHAPTER XV}

\section{BORNEO}

I. Dimensions of Borneo : how divided among the Powers.II. Orography and hydrography. - III. Climate, flora, and fauna.-IV. The inhabitants : their manners and their civilisation.-V. The establishment of Dutch supremacy in Borneo. -VI. Administrative divisions and principal towns.-VII. The economic situation; what it may one day become.

\section{CHAPTER XVI}

Celebes and its Dependencies .

I. The situation and aspect of Celebes.-II. The physical geography of the island ; its climate, fauna, and flora.-III. The inhabitants : Bugis, Macassars, Alfours, Toradjas.-IV. The establishment of the Dutch in Celebes.-V. Administrative divisions : I. Residency of Celebes and dependencies; 2. Residency of Menado.-VI. The economic outlook and the future of Celebes.

\section{CHAPTER XVII}

\section{The Moluccas and New Guinea}

I. Physical geography of the Moluccas.-II. Their inhabitants.III. The Dutch in the Moluccas.-IV. Administrative divisions ; (a) the Residency of Ternate and dependencies; (b) The Residency of Amboin.- $V$. The Residency of the West of New Guinea.-VI. The economic future of the Moluccas. 


\section{CONTEN'TS}

\section{CHAPTER XVIII}

Timor and its Dependencies-Bali and Lombok

I. The physical aspect of Timor and the character of its inhabitants.-II. The dependencies of Timor: Flores, Solor, Alor, Sawu, Sumba.-III. Administrative divisions of Timor and its dependencies.-IV. Bali : the island and its people.-V. Lombok : the island and its people.-VI. The establishment of the Dutch power in Bali and Lombok; the administrative divisions, and the future of the Residency.

Conclusion

INDEX 


\section{LIST OF ILLUSTRATIONS}

Bromo and the Sea of Sand .

Frontispiece

PAGE

A Wayside Fountain, Java $\quad$. $\quad$. $\quad$. 20

Avenue of Banyans, Buitenzorg • . . . 38

Temple of Boro Budur . . . . . . 4.48

Tiger-baiting, Java $\quad$ • $\quad$. $\quad$. 56

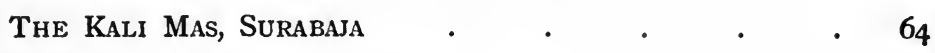

Grimm's Restaurant, Surabaja $\quad$ - $\quad$. $\quad$ • $\quad 68$

The Old Simpang Club, Surabaja . . . . 68

Native Boats, Willemskerke, Surabaja • . $\quad 72$

Chinese Kampong, Surabaja . . . . . $\quad 72$

Arab Mosque, Surabaja $\quad . \quad$. $\quad . \quad$. $\quad$. 78

Chinese Temple, Surabaja . . . . . 78

A Tenggri Village, Tosari . . . . . . 82

The Hill Station, Tosari . . . . . . 94

The Sanatorium, Tosari $\quad . \quad$. $\quad . \quad$. $\quad$. 94

A Javanese Bridegroom . . . . . . i i

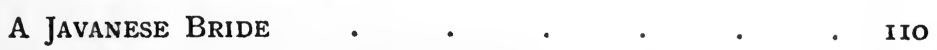

A Gamelan, or Native Orchestra . . . . 127

A "Wayang": Javanese Players . . . . . ${ }^{32}$

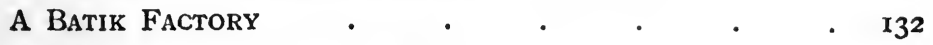

AN Arab Trader, Surabaja . $\quad . \quad$. $\quad$. 156

AN ARab Trader's Wife . . . . . . 158

A Sundanese Peddler selling "Batavia Goods" . ${ }^{1} 8$

A Chinese Merchant and Family . . . . 162 


\section{xiv \\ LIST OF ILLUSTRATIONS}

Chivese New Year's Festival

Native Policemen . . . . . . . . 166

Chinese Kampong, Batavia . . . . . . 170

Back of the Chinese Kampong, Batavia • • . I70

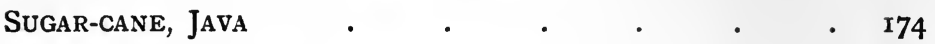

Rice and Coffee Lands, Java $\quad . \quad$. $\quad . \quad$ I74

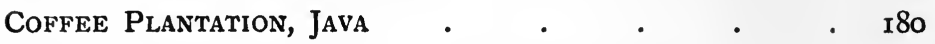

Making a Garden in the Virgin Forest, Java . . 180

NATIVE IRRIGATION WheELS • • • • 220

Native Engineering: A Bamboo Cantilever Bridge . 220

A Javanese Tea Plantation $\quad$ - $\quad$ • $\quad$ • 232

Malays of Menangkabau, Kota Gedang • • $\quad 268$

Dwelling-house and Rice Granary, Batipu, Sumatra . 270

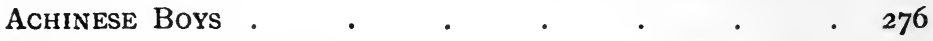

Native Loom, Acheen . . . . . . . 276

A Malay Dwelling-house, Kota Gedang, Sumatra $\quad 288$

A Kanari Kampong, Solok, Sumatra. • . . 296

Government Official's House, Borneo • • • 308

A Rope FERry, Borneo . . . . . . 308

Dyaks at Kutuung, Sarawak . $\quad . \quad$. $\quad . \quad 314$

Sumatrese Girls at Work • • • • • • $\quad 324$

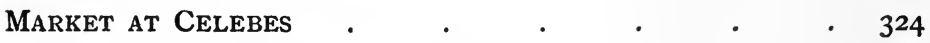

"Wayang" Actors, Singaradja, Bali . . . 360 


\section{NOTE}

THE official Dutch orthography, with one or two slight modifications, has been preserved throughout the book. The Dutch oe has been represented by $u$; the exact sound inclines to that of the German $\ddot{u} ; d j$ and $t j$ should be pronounced $d c h y$, tchy, but with a very slight insistence on the $y ; n j$ is like the Spanish $\tilde{n}$, or the $n i$ in onion; $g$ is always hard. In the atlases those names commencing with $t j$ which are most familiar to the traveller are spelt commencing with $\mathrm{ch}$; but for the sake of uniformity the translator has, hardly without exception, kept to the correct spelling, only substituting $u$ for the Dutch oe.

In addition to the works cited in the footnotes, the author's principal sources of reference have been: the Encyclopadie van Nederlansch-Indië . . S Samengesteld door P. A. Van der Lith, A. J. Spaan, F. Fokkens, J. F. Snelleman (Leyden, I896-I905, 4 vols., large 8vo); a vast compilation of everything relating to the Dutch Indies, of which the Dutch are justly proud ; the masterly work by P. T. Veth, Fava, geographisch, ethnologisch, historisch, and edition, by J. F. Snelleman and J. F. Niermeyer (Leyden, 1896-1907, 4 vols., 8vo); the sincere and picturesque study by the deputy $\mathrm{H}$. van Kol, Uit onze koloniën. Uitvoerig reisverhaal (Leyden, 1903, large 8vo), and a lucid, methodical work by the same author on Dutch and European colonial systems, the Regeerings Almanak voor Nederlandsch-Indië 1909 (Batavia, Landsdrukkerij, 2 vols. 8vo), and the Kolonial verslag van 1908. Zitting 1908-9 (The Hague) gedrukt ver Algemeene Landsdrukkerij, 1909, folio. In the maps, Ajerr, Batang, Kali, Kroeëng, Soengai, Sungai $=$ river. Těloek, Dano $=$ lake. Noesa, Poeloe (Nusa, Pulu) $=$ island. Oedjoeng, udjung $=$ point. $\quad$ Tandjong $=$ cape . 
Boer, Bur, Boekit, Bukit, Dolok, Goenoeng, Gunung, Tor, Glei = mountain.

The best atlas of the Dutch Indies is that by J. W. Steemfoort and J. J. Ten Siethoff : Atlas der Nederlandsche bezittingen in Oost-Indië (The Hague, Smulders); but the Atlas van Nederlandsch Oost-Indië, by W. Van Gelder (Groningen, Wolters), a convenient and classical publication, issued at a moderate price, will answer all practical purposes.

The translator has to thank Mrs. George Watson for the use of a number of photographs ; and the publisher's thanks are due to $\mathrm{M}$. Cabaton for the use of a series of photographs issued by the Dutch Colonial Institute. 


\section{J A V A}

CHAPTER I

\section{HISTORICAL SKETCH}

\section{By the Translator}

I. The lost continent of the Pacific.-The significance of coral.The old theory of the Asiatic irruption.-The new theory of the Polynesian migration.-Both anthropology and philology unreliable.-Probable origin of the Malays.-Traces of their passage in India.-Two languages.-The Hindu or Buddhist invasion.-Adjih Saka.-The nomadic legend.-Its probable interpretation.-Buddhist missions.-Immigration in bulk.-Javanese chronicles.-Lack of political cohesion.-Was the Javanese civilisation a high one?-Monuments.-The Hindu dynasties. -The Arab missionaries.-Demak.-The Arab warrior priests, and the fall of the Hindu Empire.-II. Arrival of the Europeans, - The Portuguese, Dutch, French, and English.III. Sir Stamford Raffles and English rule--Recent developments, -Education and future prospects,

I.

A GLANCE at the map of the Pacific will show us that the innumerable small islands lying between the Malay Archipelago, Australia, and America, fall roughly into five or six groups: in other words, they are the peaks of as many vast ranges of submarine mountains. Each of these groups represents such an archipelago of small mountainous islets as would take the place, let us say, of Java and Sumatra, were a stupendous volcanic catastrophe or a gradual subsidence to sink them some thousands of 
feet below the surface of the sea. It is therefore reasonable to suppose that they represent a sunken continent, which was traversed by many mountain ranges; or if not a continent, several islands of gigantic area.

That the islands of the Pacific were not thrown up as they now stand, and are not now rising, is proved by the existence, round nearly all of them, of coral reefs; while in many cases the peak has disappeared altogether, leaving only an atoll, or a vast circular reef of coral. Moreover, there are long lines of such reefs enclosing large areas of shallow sea. The coral polyp cannot live below a very moderate depth of water, and builds with extreme slowness : conclusively proving these islands to be the summits of large bodies of land, which have been slowly sinking during a period of incalculable duration.

A few years ago the theory was generally accepted that the whole of Polynesia, the Malay Archipelago, and Madagascar, were populated by a Mongolian irruption from Asia, which passed from the Peninsula to Java before the Straits existed, and, finally becoming a maritime nation, spread east and west over the entire Pacific and Indian Oceans. This theory was accepted in spite of the very obvious differences between the best type of Maori and the ordinary Malay; between the coast and the inland Malay; between the black Polynesian and the fairskinned Polynesian; and the distinct cleavage of languages. The presence of negroid or Negrito peoples was explained by an immigration from India, and perhaps from Africa alșo.

Lately the opposite theory has been favoured: that the sunken Pacific continent was the home of a Pacific race, perhaps of considerable civilisation, which emigrated northward and westward as the continent sank, while also retiring to the mountains, which finally became islands. It is also suggested that various races of South-Eastern Asia which show affinity with the Malays had the same origin. ${ }^{x}$

- Anthropologists are apt to lose sight of the fact that all problems of ethnology cannot be settled by measurements of the skull. 
Were either the Polynesian or the Mongolian theory true, we should expect to find a homogeneous race and language from New Zealand to Madagascar. Setting aside such minor problems as certain fair-haired races who may represent remnants of some Celtic movement, or of the migration of Arabs with a Gothic strain, and black races who may be aborigines of Australia, Africa, or Hindustan, the unprejudiced observer is inclined to see two principal races: a true Polynesian race, of which the finest and most highly specialised type is the Maori, and a true Malay or Mongolian race. The Polynesian languages have little in common with Sanscrit : the Malay tongue has much in common with it. There are Malays speaking the Malay tongue upon the Malay Peninsula, the natural highway from Asia. The true Polynesian is peculiar to the Pacific; and the Polynesian language has as many dialects as the Polynesian skin has shades of brown. Moreover, the Malays, although bold navigators, have not pervaded the whole of Polynesia, and their vessels, houses, and

Round-headedness and long-headedness, wherever two races mingle, are presumably Mendelian characteristics, one of which is dominant, so that in the process of natural selection we may reasonably expect to see one type of skull predominate, or pass from one race to another, which would preserve, in an unmixed state, the opposite type of skull.

Philologists, again, do not always remember that while a conquering and civilising race may either stamp out or adopt the tongue of its inferiors, or produce a hybrid language as the result, it is also true that when a highly organised and simplified language with a rich practical vocabulary comes into even casual contact with a lower, and in some senses a more complex tongue, devoid of generalisations and of qualifying terms, there is likely to be an absorption of the more highly organised tongue which need not be accompanied by any racial admixture, or more than a slight racial contact. The reader must remember that theories are changing every year, and that the specialist in one science contradicts the specialist in another. The present writer, in attempting to give some account of the peoples of Indonesia, can but endeavour to keep the middle line and to avoid improbable extremes, while adducing certain facts in support of the theory of dual origin. 
art in general show more Chinese and Arabian than Polynesian influence. This suggests a recent arrival; while the varieties of the Polynesian suggest long specialised evolution.

There is no race in Asia resembling the Polynesian of the south: whereas there are races in South-Eastern Asia having affinities with the mixed Indonesians and Malays.

The inhabitants of Java were called Rasaksa by the first Hindu invaders. In many parts of India, on the borders of the forests, the natives to this day believe in and fear a demon known as the Raksha. ${ }^{\mathbf{I}}$ They describe it as having eyes set obliquely in the head; it is ugly, broad, bulky, mis-shapen, and has terrible teeth. It haunts only the forest and the tops of hills, and is given to decoying children or solitary women. It also has a terrible cry: an important point, of which more anon.

A race of Mongols or Huns was for a long period kept out of China only by the Great Wall. This would seem to show that they for some reason desired to migrate, to extend their nomadic empire; probably because the plains of Asia were overpopulated, for a nomadic people requires a large country for its support.

Now the Malays themselves had a legend that they came from the East, crossing to Java and Sumatra when the Straits were solid land. Any great migration across India or the slopes of the Himalayas would have driven the then inhabitants of the concealing forests

I See, for particulars of this very significant superstition as found among the eastern hills of India, "Old Deccan Days, or Hindoo Fairy Legends," collected by Mary Frere. Her mention of this superstition as existing in Scinde (where the demon is known not as a Raksha, but as a Djinn) seems to lend support to the legend as related by Raffles, to the effect that the invading nomads came from the neighbourhood of the Red Sea (Persian Gulf ?). Their route would then lead them through Baluchistan to Scinde, whence they would presumably have crossed India by keeping to the hills and forests. Even did they come from Central Asia (as seems most probable) they may well have entered India viâ Persia, Baluchistan, and Scinde. 
to seek safety in flight. But now let us consider the tail-end of such a migration, when the normal population would have returned to their homes. Dangerous, furtive savages would continue, perhaps for years, to slink through the Himalayan passes, cross India by means of the hills and forests, and so make their way southward. They might well, being a people of the plains, employ a mustering call or shriek in the forests, or employ a ritual marching-cry. They would not encourage stray children or women. They disappeared untold centuries ago; they are not met with, now, as human passengers through the woods. What could the Hindu make of them, when once they had passed, but slant-eyed demons who shrieked in the woods?

Again, the nomads of Central Asia were horsemen. This we know from the writings of classic and early mediæval writers. But they could not ride their horses through the Himalayas or the forests. The hordes which invaded Europe-Tartars, Huns, and Vandalswere chiefly or entirely a pastoral people. Only their custom of driving with them the herds of cattle upon which they lived could give them the mobility which rendered raiding possible. That there were agricultural nomads in Central Asia, who sowed and reaped and migrated yearly, we know from the Vedic writings : the Aryans who settled India were such.

Bearing all these facts in mind, let us now go forward to the commencement of the historical era in the Malay Archipelago.

According to Raffles, the tradition concerning the race whom the first Hindus found established in Java was as follows: they were nomadic, travelling in hordes, but they lived by agriculture and migrated afoot. Only the elder of the tribe, who was its chief and high-priest, was carried with his family in a litter or borne upon an elephant. The year's crop being gathered, the fresh migration was directed by an omen-the flight of a bird. Apparently the sun and moon were worshipped; but a certain amount of general animism appears to have pre- 
vailed. At times of augury or sacrifice, or to express homage to the chief while travelling, or to frighten away wild beasts, the young men set up loud shouts and screams; "as do the Dayas of Borneo to this day on like occasions." I These people were known as Rasaksa.

These Rasaksa, or Malays, have remained almost unmixed in Sumatra, except upon the coast, where there has been a considerable interfusion of Chinese and also of Arab blood. The civilisation of the Sumatrese is largely Arab with traces of Chinese influence; their religion was brought by the Arabs. In Java there has been a very considerable interfusion of Hindu blood, which is betrayed by the darker tint of the Javanese natives and by their finer features. Animists, or sunworshippers, in prehistoric times, they were rapidly converted to Buddhism, which in time merged into the Shivaite cult; and until the Mahomedan conquest of Madjapahit their civilisation was of the Hindu feudal type.

Of the outlying islands some are still Hindu; others are largely animistic. The religion of the Polynesians may be roughly described as a mixture of fetishism, idolworship, animism, taboo, and in some cases, apparently, ritualistic or sacramental cannibalism.

We must remember that this early legend may have been "telescoped" by the Hindu or Javanese historians, who may have inserted echoes of the Vedic hymns. But regarding it as authentic, and bearing in mind all the preceding facts, and in especial the partly Asiatic character of the Malay ships and houses and the limits of Malay colonisation, is not the conclusion almost irresistible that a tribe of Mongolian nomads, driven from Central Asia by fiercer or more mobile enemies, or by some unknown catastrophe, such as a disease, a

I Raffles states that the princes of the eastern part of Java used to favour a dance performed by men with tangled hair, clad in leaves, who shouted and leaped and shook the angklung, a rude instrument which is mentioned in the early legend : these dancers represented the supposed aborigines. 
blight, a cattle pest, or by a prophecy or a superstition, found their way across or around the Himalayas, through the forests and the uplands of India, down the Burmese border, finally reaching the Malay Archipelago, and perhaps the regions to the east thereof? Whether they remained there, as appears probable, until they learned navigation from the settled inhabitants of the country, ${ }^{x}$ or whether they were able to march into Java by land, is not a matter of great importance; but the fact that the Peninsula contains a large Malay population inferior in civilisation to the Malays of the Indies seems to favour the theory of a temporary halt. Then, it seems, they spread through the Archipelago, sometimes exterminating but more often absorbing the aborigines, or driving them to the mountains; finally colonising the borders of Polynesia and superimposing themselves upon that ancient oceanic race, whose peculiar conditions had perhaps caused a relapse from a higher and more ancient continental civilisation, while they had prevented any physical degeneration. We may regard the true coast Malay as the Asiatic nomad with Chinese and Arabian blood in his veins, and the various peoples of mixed Malay blood who are known as Indonesians as a hybrid between the Mongolian and Polynesian elements, though here and there the Malays or Indonesians may have mingled with the black races of African or Indian origin.

Proceeding now from tradition to the chronicles, we find ourselves in a maze of contradictions, inconsistencies, miraculous anecdotes, and legends, compiled in all probability (since the adventurers who settled Java are not likely to have brought court records with them) from the boastful oral traditions and narratives of warriors, priests, and female elders of the palace. From these chronicles it is not possible to judge which princes may be supposed to have reigned in Java and which were actually Indian rulers.

It is apparently agreed, however, that the first Hindu

- These may have been Chinese or black aborigines from India ; probably both were present, the Chinese as maritime settlers. 
to send or to bring an expedition to Java was Adi Saka, or Adjih Saka. His advent, or expedition, is by some attributed to the year 75 A.D. While he may have been merely a nameless ruler (Adi) or a prince who afterwards took his name from Atjeh (Achin), it is not altogether improbable that we have here a mention of the great Buddhist ruler Asoka, King of Behar, who in 244 B.c. commenced that wonderful Buddhist propaganda which established Buddhism in India and gave it a settled hierarchy. His policy, which resembled that of the Jesuits in that road-making and preaching, well-sinking and education went hand in hand, resulted in a vast missionary organisation which is known to have spread as far as Ceylon. His son carried on his work. The great Buddhist ruler of the first century of our era was Kunishka, whose name cannot by any corruption have come to resemble Adi Saka. ${ }^{\text {I }}$

When we remember that Saka means the founder of an era, therefore a prince, and also Buddha himself, it is evident that the first chapter of Javanese history does not carry us very far.

Some chroniclers attribute the introduction of Buddhism, or rather of Brahminism, to one Tritestra, a priest; others regard him as identical with Adi Saka. His descendants are supposed to have ruled Java.

It seems certain that further Buddhist invasions took place in the fifth and seventh centuries. There are mentions of rulers coming from abroad and of expeditions of as many as twenty thousand priests, warriors, and craftsmen. For centuries, we may suppose, Java was regarded as an Eldorado where any refractory vassal or adventurous refugee or superfluous prince might win a kingdom; standing in relation to India as Brazil did to Portugal.

Powerful states must have arisen early in the history of Java, as is attested by the remains of gigantic temples,

- The constant mention of Asoka as the great patron of Buddhism may have led remote chroniclers to believe that he was alive centuries after his death. Adi Saka is perhaps Adi Asoka. 
primitive in respect of construction, but superb in decoration and finish. Whether these wonderful monuments are proof of a very cultured state of society is doubtful. There was more movement in Asia a thousand years ago than now; craftsmen of all countries may have been attracted to the new, fertile, wealthy land, which was full of royal courts and powerful feudal chiefs. Of the condition of their employers we know little. Hindu art, however, touched its zenith in Java, though, as we have seen, the architecture was primitive in plan, having usually an earthen core.

It is difficult to judge how soon Java became, even nominally, a single kingdom. We are told, however, that in the year II57 the kingdom of the second $\mathrm{Aji}$ Saka was divided into four kingdoms, which then became incorporated into the empire of Pajajaran, which was afterwards known as the empire of Madjapahit. This lasted from 1376 or 1396 to 1476 , when it fell before the assault of the Mahomedans. The empire being a feudal State, there still remained Hindu kingdoms, most of which were rapidly broken up or converted. The first Mahomedan State of Demak became the empire of Mataram. Gradually the States were absorbed by the Dutch, with the exception of the empire, which was divided into the two Principalities which are still extant. But the feudal framework of society has remained and is to-day employed as the means of government and administration.

The fall of Madjapahit is a long and intricate romance - too long for insertion here. It was attacked by the recently formed Mahomedan States of the seaboard, which were largely the result of Arab missionary effort. Java was converted to Islam almost as readily as to Buddhism, the truth being that the Javanese is at heart an animist. He utters the invocation "There is no God but God and Mahomed is His prophet," but he does so facing a stone altar which stands beneath a tree: the primitive village altar of India. To-day, despite Islam, that stone is the abode of the patron spirit of the village. 
Every field, every garden, every hill and valley has its emanation, its spirit, capable of good or evil, to be offended or propitiated ; every disease its demon. Some of the greater spirits, who are dignified by names, hold almost the position of demigods, such as Rata Loro Kedul, the princess of the Indian Ocean. Not only the genius loci is to be feared, but every seeming inanimate object has its indwelling spirit. The better-class Malays and the Javanese nobles are often reasonably orthodox; but the teaching of Islam has never disturbed the fundamental beliefs of the people. As in parts of Italy, the old pagan beliefs remain; but Islam has not absorbed the indigenous gods as the Catholic Church has done. It was probably a revulsion against feudal tyranny, a weariness of the caste system, the jealousy of a superior race, and a human desire for loot that led to the sudden conversion of the Javanese arrd the extensive substitution of the Malay civilisation, partly Arab, partly Chinese, partly native or Indonesian, for the rigid rule of the Brahministic hierarchy. Led by the genuinely fanatical Arabs and the jealous Malays of the coast, the converts formed a force which the less primitive Hindus were unable to oppose.

An effort to convert the princes of Sunda to Islam was made by the Arab traders and priests about I250 A.D. It was unsuccessful. Before this date a brother of a prince of Pajajaram returned from India as a convert, accompanied by an Arab, and attempted to proselytise his brother. A few years later an attempt was made to convert the Rajah of Madjapahit, the Rajah of Cherman putting forward his daughter as an inducement. The death of the princess and her suite by an epidemic disease set a term to this propaganda; but the progress of Islam in India and among the Malays of the coast, who were in constant contact with Arab traders and residents, was rapidly increasing.

History states that the Rajah of Madjapahit was defeated by his own son; his son by a Chinese wife, whom he gave to a vassal to please a later wife. Vassal and 
son were converted to Islam, and in the course of years the son was given a fief, which he erected into the State of Demak, by his father, against whom he finally headed a powerful federation of Mahomedan leaders, his grievance being the treatment which his mother had received. $\mathrm{He}$ was opposed by his half-brother, the emperor's commander, but eventually captured the city. During his adolescence the empire absorbed nearly all the islands now known as the Outer Possessions.

The destruction of the great city was followed by the dispersal of all the craftsmen of Madjapahit, including the famous workers in steel. Many of them settled throughout the islands; one result being the general adoption of the krees. Many bodies of Hindu worshippers fled, refusing to change their religion, which is still extant in certain parts of Java and the isles.

\section{II.}

Spices came from the unknown, gorgeous East: untrodden, since the downfall of the Bactrian States, by any Europeans but the Polos. Gold also and precious jewels, silks, carpets, ivories and embroideries, and many another precious merchandise beckoned the adventurers Eastward. Partly to obtain such goods at first hand, so saving the enormous cost of transport by sea, caravan, and once more by water, of the dues of many ports, and the profits of many middlemen, and partly to make territorial conquest and to spread the Christian faith, the Portuguese, at the end of the fifteenth century, when the power of feudalism was broken and Portugal was full of landless, masterless, or ambitious men, began to search for the kingdom of Cathay.

Columbus, bearing a letter to the Khan of Tartary, had sailed in 1492 under the Spanish flag in search of Asia westward; discovering the West Indies. Five years later Vasco de Gama set out from Lisbon, rounded the Cape of Good Hope, and reached the city of Calicut in India. The "Moors," or Arab traders of the west, 
were hostile to his enterprise; but the Zemindar of Calicut gave him a letter to the King of Portugal, asking for "gold, silver, and scarlet," and offering in return cinnamon, cloves, ginger, pepper, and precious stones. The safe return of da Gama stimulated the greed of the Portuguese. The king commissioned his admirals to acquire territory and to spread the Christian faith.

The second expedition, of thirteen ships, set out in the winter of I499. Cabral, the leader, losing his bearings, discovered the coast of Brazil, but eventually arrived at Calicut, founding factories there and at Cochin.

In 1502 Pope Alexander VI. proclaimed the King of Portugal lord of the lands and seas and commerce of Africa, Persia, and India. In that year da Gama made his second voyage, his fleet numbering twenty vessels. Next year Alfonso de Albuquerque-the only Portuguese to leave a savoury reputation in the East-commanded one of three fleets. In $\mathrm{I}_{505}$ Almeida set sail with no less than fifteen thousand troops. ${ }^{x}$ In 1509 Albuquerque succeeded him as second Viceroy of India. Failing to reduce Calicut, which Vasco da Gama had bombarded in 1502 , he fell upon Goa.

Henceforth the admirals had sought to trade only with India. Now, in I5 I0, Albuquerque visited Sumatra. Capturing Malacca in the following year, he sent envoys to all parts of the Archipelago, announcing his desire to trade. To Java and the Moluccas he sent one Antonio de Abrew, who formally took possession of Amboin, opened up the Molucca trade, and on returning called at many Javanese ports.

Albuquerque, after a voyage to Arabia, returned to Goa, only to die there in $\mathrm{I}^{\mathrm{I}} 5$. He had won the friendship of many Hindu princes, and was so just a ruler and $a$ friend that his tomb was long venerated both by Hindus and Mahomedans.

I Most of these fleets touched at Bahia, on the Brazilian coast; the Brazilian trade was in fact developed by the Indian fleets, while the possibility of refitting and provisioning in Brazil and Madagascar greatly facilitated the Indian trade. 
The King of Malacca, who had been expelled by the Portuguese, was cruising vengefully, with piratical intentions, in the Straits of Singapore, so that vessels sailing to the Spice Islands (the Moluccas) were forced to go by way of the Straits of Baban.

In 1522 one de Lerne was sent to Bantam, which was still a Hindu kingdom, to establish commercial relations. The king was then being pressed by the Mahomedans, and inclined to make terms with the Portuguese. $\mathrm{He}$ promised a site for a factory, freedom of trade, and an annual payment of one thousand bags of pepper, if the Portuguese would build a fort to defend the port. In due course, permission having been obtained from the King of Portugal, Francisco de Sá arrived to build the desired fort; only to find that the exiled and Mahomedan King of Malacca had just seized the city, and was master of the State. For the time being all hope of settlement on Javanese soil was abandoned.

The cruelties of Albuquerque's successors caused the princes of Western India to revolt, in concert with the King of Achin. They were severely defeated; nor was the King of Achin more successful when in 1578 he besieged Malacca ; the tiny Portuguese garrison inflicting upon him a loss of ten thousand men. In $1_{6} \mathrm{I}_{5}$ and in I628 the Achinese again attacked Malacca, again to be repulsed.

Towards the end of the sixteenth century the Indian trade had assumed immense proportions, and Lisbon was the richest port of Europe. Portugal was empress of the seas. As many as 250 vessels would leave Goa in a single convoy.

Hitherto the Portuguese had made no extensive territorial conquests, but had seized and garrisoned many cities, had built many factories, and had acquired a few strips of land. A few of the smaller islands were actually or nominally Portuguese, and commercial treaties were concluded with many friendly States. The number, size, and armament of their vessels enabled them to beat off pirates and to drive many of the Malay and Arab traders 
from the narrow seas; thus their monopoly was absolute, as far as Europe was concerned, from Japan to Arabia, and from India to Madagascar; while the Atlantic coasts of Africa and Brazil were largely in their hands.

In 1580 , however, Dom Sebastião was killed in battle, and Philip II. of Spain was not long in annexing Portugal.

Spain needed all her money and all her men to further her European policy. For a time, however, the trade from Lisbon held its own, and even increased; but it was ill-defended, so that the Dutch and English quickly became formidable rivals.

While Lisbon had been the emporium of the Eastern trade, the Dutch ports had become the chief distributing centres. Both Holland and England were eager to break the monopoly; but for more than seventy years the Portuguese kept the secret of the Cape route.

As early as 1496 the four Cabots had attempted the north-west passage ; their voyage ending in the discovery, not of India, but of Virginia. In ${ }_{553}$ Willoughby attempted the north-east passage, but was frozen in and died. Chancellor, his lieutenant, found his way into the White Sea, and, marching south to Moscow, laid the foundations of the Russian Company, which was formed to carry on the overland trade with Persia and India. Other explorers vainly attempted the Arctic routes. At length Drake, in I573, on his voyage round the world, put in at Ternate, one of the Moluccas, whose king agreed to supply England with all the cloves which his island yielded. In I579 Stephens, an Oxford graduate and a Jesuit, landed in India; his letters home caused a great sensation among the City merchants. In ${ }^{583}$ three English traders sailed to India as private adventurers. One, after being imprisoned by the Portuguese, entered the service of the Great Mogul; another, after travelling through Burmah, Pegu, Siam, Ceylon, and the Malay Peninsula, returned to England; one settled at Goa as a trader. In 1599 the Dutch, who had at last appeared on the scene, and had already gained a footing 
in spite of the Portuguese monopoly, raised the price of pepper from 3s. to 8s. per $1 \mathrm{~b}$. The English now knew the way to the East, and promptly formed the English East India Company, in order to obtain the spices of the East directly. This Company, absorbing all its rivals, endured until I823.

The first voyage was undertaken in 1602 ; relations were established with the King of Achin, the Moluccas, and Bantam, where a factory was erected. Further voyages resulted in extended relations, and the Company prospered rapidly; but in 1623 , as a result of the massacre of Amboin, when the British settlement was destroyed by the Dutch, who had taken the island from the Portuguese in 1605, it withdrew from most of its East Indian posts, and quickly became absorbed in operations on the mainland of India. Compensation for this infamous massacre was exacted by Cromwell some thirty years later.

To return to the Dutch: the secret route to the Indies being at last discovered, Cornelius Houtman had rounded the Cape in 1595. The Portuguese were still endeavouring to reduce Bantam; Houtman agreed to assist them provided that he might erect a factory when the port was captured.

The Portuguese fleets and ports being ill-defended by Spain, the Dutch became not merely successful competitors, but seized the Portuguese possessions in the East, as they did on the coast of Brazil. Trading companies began to spring up in the Netherlands; in 1602 the Dutch East Indies Company was formed, which absorbed all its rivals, as did the English Company. Within a few years the Dutch were established on every hand: in India, Ceylon, Sumatra, Java, the Moluccas, and elsewhere.

Reviewing the century's progress, we find that at the outset the Company obtained only sites of factories and forts. There were still emperors of Java; the house of Demak gave place to the empire of Mataram, whose capital, Kartasura, was near the site of the modern 
Surakarta. In I6 Io the first Dutch Governor-General was appointed. Finding the Dutch position in Bantam indifferent, he removed in I6I8 to Djakatra. In I62I the new settlement was called Batavia, and became the capital of the Company's government. The choice of site was disastrous : at one time a million Dutch soldiers and officials perished of fever within twenty years; a fact hardly surprising, since the town was built in the European fashion upon the pestilential swamps of the coast.

Then followed the interminable war between Holland and England, which ended only in I688. By 1683 the English had withdrawn from Bantam. Peace once concluded, they became deeply engaged in India. The Portuguese had almost vanished from the East; except in India the Dutch were supreme. In 1705 they obtained the Preangers by treaty; in I745 they gained possession of the northern seaboard; and in I755 the empire of Mataram was divided into the states of Djokjakarta and Surakarta.

The history of the Dutch Company is unsavoury. It was an armed instrument for extracting wealth; that it might have a freer hand even soldiers and minor officials were confined, as far as possible, to Batavia. It demanded fixed quantities of produce or money from the native rulers ; but at first it left the dirty work of collecting such produce to the rulers themselves, asking no inconvenient questions. Afterwards it took hand in the work itself to a limited extent. Even in the days of the Crown administration this system was again put in force; an iniquity (much as it finally profited the native race) exposed by Douwes Dekker in his novel Max Havelaar, the work of an official who had lived his life as a Dutch official in Java.

Cruelty and lack of conscience was the first of the Company's mistakes. The second mistake was that it based its expectations, not upon the general wealth and development of the country, but simply upon the monopoly in spices. Both monopoly and supremacy were 
broken by Clive in 1758 , when he inflicted upon the Dutch the ignominious defeat of Chinsurah.

When the Franco-English War of $178 \mathrm{I}$ broke out the Company was already failing. In that same year Thomas Stamford Raffles was born at sea, off the coast of Jamaica. In these two events lay the seed of a new order of things.

In 1780 the States, by a majority of one, had decided to adopt the policy of "armed neutrality"; in other words, to side with France and Russia as against England. War broke out at once, although the Stadtholder and the Court were opposed to the popular party. Peace was concluded in 1783 , but the Dutch were forced to admit the English to free trade throughout the Indies.

In 1795 the Stadtholder fled to England before the forces of the French Revolution, and the Batavian Republic came into being; to be followed, in 1806 , by the Bonaparte monarchy. In 18ro the honest Louis, unable to protect his people against his brother, retired, and Holland became part of France.

Already England had absorbed many of the Dutch possessions in the East; but Java still remained in the grip of the terrible Daendels. In I8II, however, the French flag was run up at Batavia. In the same year the British flag replaced it, after a decisive battle at Weltevreden, delivered by Auchtermuty at the head of seven thousand troops. The remnant of the colonial army, led by the French General Jumelle, escaped to Samarang, where it capitulated on September I8th. Raffles was Lieutenant-Governor of the new British colony, being subject to Lord Minto, the Company's Governor in India.

\section{III.}

Raffles was admitted to the India House, as an extra clerk, at the age of fourteen. Ten years later, thanks to his unremitting industry, his supple intelligence, and the friendship of the secretary to the Company, he was 
appointed assistant secretary to the Governor of Penang, his salary being increased from $\oint_{1} 100$ to $£_{1}, 500$. He married, before sailing, the widow of a Company surgeon, learned Malay upon the voyage, and upon landing was already a fair scholar.

A man of supreme capacity and flexibility, who had never mingled in society, was untouched by convention or tradition, and was therefore able to reap the full advantage of his unusual good sense; an ardent patriot, a keen man of business, and a far-seeing statesman; he must, under ordinary conditions, have eaten his heart out among dull and incompetent colleagues and lamentable seniors. The fact that Lord Minto was GovernorGeneral, while that erratic genius John Leyden held a post of influence, enabled him to do lasting and imperial work, though the tentacles of mediocrity dragged him down in the end.

It is impossible here to consider his work for England; we must consider his career in respect of Java only: Java, which he always maintained should be retained by England as a jewel in her crown of empire. It is enough to say that after doing most valuable work in spite of dull or timid superiors and disloyal colleagues, he was appointed by Lord Minto to be Agent with the Malay States and Lieutenant-Governor of Java.

Daendels, a pitiless Jacobin, sent out to Java to reorganise the colonial forces, had utterly exhausted the resources of the country. His legacy to England consisted of a military road built at the cost of countless lives, and a bankrupt and terrorised people.

Raffles was actuated by the feeling that it was the plain duty of England to give this people a just, humane, and suitable government; to restore it to wealth ; and finally, to make it a source of imperial strength and profit. $\mathrm{He}$ considered that retirement on the part of his country would be a betrayal, a cruel desertion.

$\mathrm{He}$ immediately gained the confidence and gratitude of the Dutch population. The Sultan and Susuhunan were restive, seeing an opportunity of revolt : Raffles handled 
them with consummate skill, promising both protection. Minto had already abolished torture : Raffles revolutionised the entire legal system. The original system of village or communal government was revived; the island was ruled through its natural hierarchy, the native aristocracy, advised by European colleagues. The country was redivided. The old forced deliveries of crops, by which the Company had lived, were abolished.

Raffles then proceeded to reform the land tenure. The Dutch had forced the natives to deliver all their crops, had bought them for a song, and resold what the natives actually required for subsistence at iniquitously high prices. Daendels had salaried the receiving officials, who had previously lived by percentage and peculation, but had left the system untouched.

After a long and exhaustive tour of inquiry, and innumerable interviews with natives of every rank, Raffles decided to let the land to the natives upon long leases, abolishing forced deliveries. At the outset the village headman let the land; but this arrangement was provisional, the tenant at last holding his land by lease directly from the Government. The rent was paid in kind, but was fixed; it was collected, under supervision, by the chief, or headman. This revolution destroyed the evils of the feudal system; the former regents were granted pensions and estates in compensation, and in return for administrative duties.

Within two years of the introduction of the new system the land rental yielded nearly half the revenue of Java. Unfortunately the enforced use of paper money resulted in an exchange rate of twelve to thirteen. This condition of affairs was largely due to Daendels. To remedy or at least to alleviate this depreciation Raffles decided to sell a portion of the public domain: a measure for which he was savagely criticised, but which none the less did much to increase the exploitation of the soil. As a result of jealousy and the hasty charges of a former friend, Raffles was requested in 1815 to withdraw from his position in Java; a piece of injustice which was felt 
the more bitterly because his work had not as yet been given time to justify itself by results. It was stated, as a complaint, that at the end of four years of administration his budget showed a deficit. That is true; but it is also true that in spite of the fact that these were years of revolution and reconstruction the deficit was less than it had been for more than twelve years; moreover, it was less each year, and had the rate of decrease continued constant (but it would undoubtedly have improved) two years longer would have shown a surplus, after which the island would have been not merely self-supporting but an asset of imperial wealth.

Already it had been decided that Java was to be returned to Holland. Raffles was appointed Resident in Bencoolen, Sumatra ; but almost at the moment of his retirement a curious conspiracy was unmasked at the court of the Susuhunan. This monarch, at whose court was a guard of sepoys, had attended their Hindu services, and had given them, for purposes of worship, some antique Hindu idols preserved in the palace. The sepoys thereupon sought to persuade themselves and him that he was a descendent of $\mathrm{Ra}$, destined by the gods to restore the Hindu empire. Had he declared himself his people would probably have followed, and a terrible upheaval might have convulsed the islands. Raffles quickly subdued the rising, without severity and without a display of force.

Java was actually taken over by the Government of Holland in 1818 . The Dutch had the wisdom to recognise the excellence of Raffles' work, and continued to govern according to the system he had created.

Of the return to the bad old methods known as the "system of forced cultures" there is only one good word to say. It resulted in the reclamation of yet more virgin soil; so that the effect of this system, together with the reforms instituted by Raffles, was an increase in the population from $4,500,000$ to $30,000,000$ in less than a century.

The last serious hostilities in Java broke out in 1825 , 


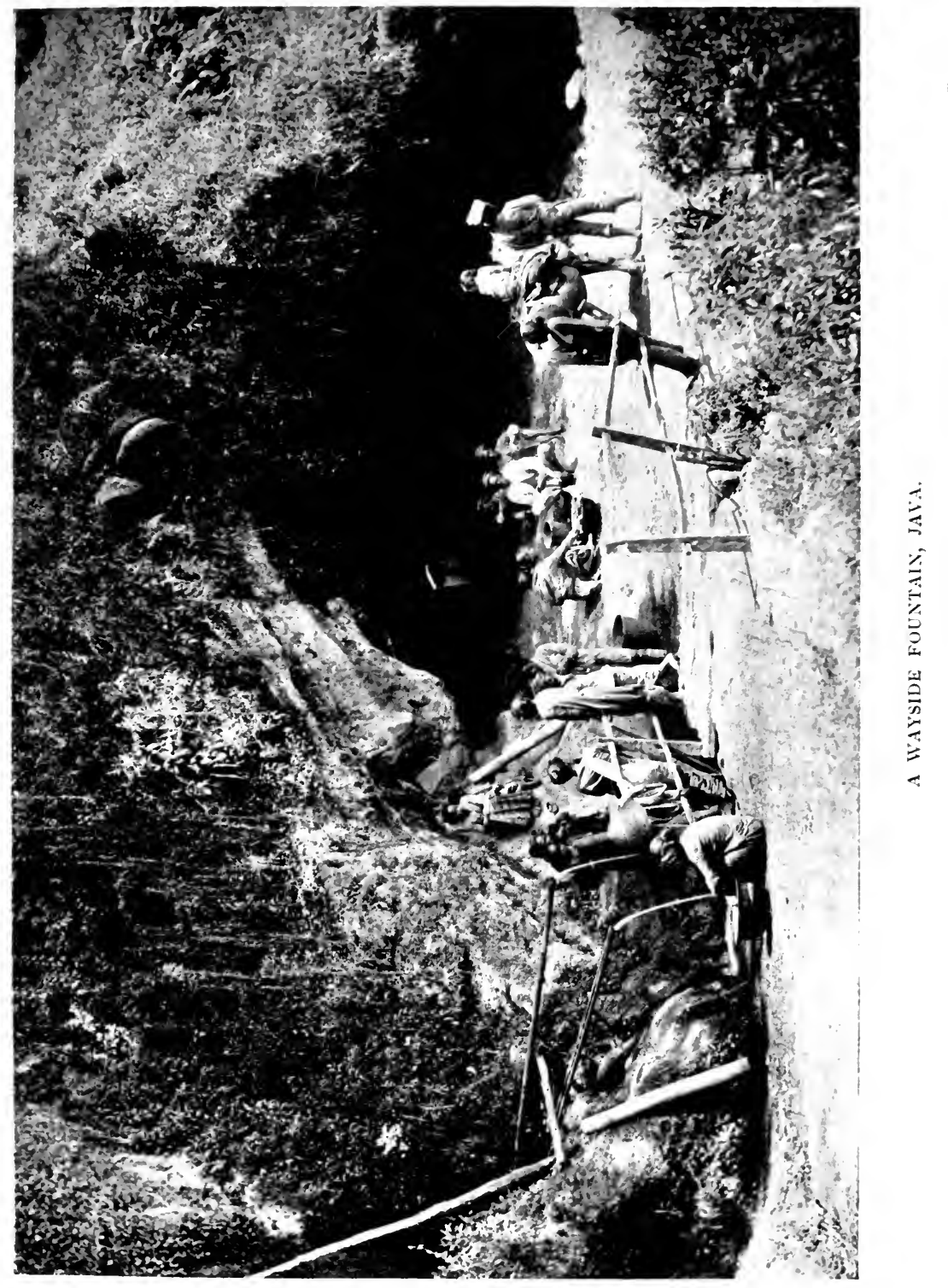



when Dipo Negoro claimed the entire island. The rebellion was subdued at the cost of five years of warfare and the loss of fifteen thousand men. When at length the island was pacified the hold of the Dutch was firmer than ever. There were further attempts at revolt, when the Mahomedan priests sought to persuade the people that Dipo Negoro had returned, or was still alive. The most serious attempt was in 1849 , when the exile was in Macassar. He died in 1855 , and the last rebellion was in I888. These revolts have resulted in the entire loss of local independence. In 1848 sweeping reforms were introduced by the Grondwet, or Fundamental Law ; and during the last sixty years the Government has grown more and more paternal, humane, and enlightened, until it is now an example to other nations. The increasing immigration of private colonists has had an excellent effect, and has fulfilled the colony's natural destiny.

Hostilities still continue in Sumatra, in the jungles of Achin, but only on a small scale, as all the towns are in the hands of the Dutch. This Achinese War has been well-nigh interminable, and the cost in lives and money has been deplorable. The pacification of the country is at last at hand.

The chief problem of the present day is that of native education. Until recently a knowledge of Dutch or of Occidental learning was denied to the Javanese, lest they should consider themselves the equals or superiors of their masters. We may suppose the Dutch to have taken warning by the results of education in other parts of the East.

But the Javanese (the Malay is a poor scholar) is eager for Western learning; yet not so much for its own sake as for what he hopes it will give him: power, consideration, social promotion, a career, and ultimately. perhaps, national self-government as a federated colony. $\mathrm{He}$ has seen the Japanese change from a secluded feudal people to a civilised power in the space of forty years, and forgets that even in their seclusion (which was a comparatively recent matter) they were, as they had been 
for centuries, a powerful and highly civilised nation under a stable government.

Java has always been a congeries of little states; sometimes temporarily federated, sometimes hostile; unaffected by caste, but aristocratic by principle. It is, and will always be, a land of agricultural wealth. Owing to the docile nature of the people, the prevalence of agriculture, and the aristocratic framework of society, there is no need in Java for an enormous bureaucracy. Yet that, one may suppose, is what its youth would expect if educated in the rash yet timid manner usual in the East. In India university graduates, instructed rather than educated, crammed with traditional facts, but unable to handle new ones, or to co-ordinate or deduct, are forced to work at the loom for a living. What work could be found for the Javanese youth if similarly trained? The number of Dutch officials is already small, and cannot be decreased with profit to rulers or to ruled. There is no room and no occasion for any large degree of further self-government; and at present the Javanese, not being fanatical Mahomedans, and having no system of caste, trust and respect the Europeans. The problem of general education has accordingly hung fire; although the sons or successors of regents have for some time received adequate instruction of a suitable type.

It is to be hoped that the situation will find a natural solution. The Javanese will probably perceive that his future lies in the exploitation of the soil. If he desires to live as the Europeans do, to meet them on reasonably equal terms, and to assume identical interests, he has but to cultivate the land as do the planters, or to enter upon the upper walks of commerce, where a special education might enable him to oust the Chinaman.

The Javanese as things are has to learn three tonguesthe High and the Low Javanese, and Malay; literary Malay may make a fourth. If he learn Dutch as well, a limit is set at once to what else he can learn in a curriculum of ordinary duration. Agriculture he must study, with 
its underlying sciences. If, as is probable, his education finally assumes this form, he will hardly be able to learn alien philosophies and political theories which are only likely to be harmful to an ordinary Oriental, unless he be of exceptional intelligence and have leisure to travel in the West. A practical scientific training, moreover, seldom fails to teach the recipient that system of method, that power of co-ordination and constructive thought, which are usually so dismally lacking in the modernised Oriental.

The East Indies stand to-day, like Brazil, on the edge of a new era. They form a land of plenty, but their full development is a matter of the future. In that future the natives, if only because of the rate at which they increase, must play an ever-increasing part; the Malay more especially as sailor, fisherman, plantation-hand, labourer ; the Javanese as planter, cultivator, and artisan. At present the native aristocracy, who used to rule as feudal chiefs, and now rule for and with the Dutch, are paid heavy salaries and own large estates. As all their descendants cannot become regents or bureaucrats, it is obviously in their interest to learn the management of estates, with all that is thereby entailed. As the Outer Possessions become more fully developed and settled there may be a limited official scope for the youth of Java; but only, as a general thing, where the local rulers are inefficient. A time must come when the soil of the Indies will present itself to the native, as to the colonist, as the natural source of wealth; and in Sumatra the coal measures point to the probability of future industrial development. It is to be hoped that in course of time the professions of agriculture and industry will afford the upper-class native competence and an honourable calling. If there are prejudices to be overcome, it is to be hoped that a wise education will naturally break them down. The nationalist cry is only dangerous when it is a demand that a helpless and ignorant people shall be handed over to a horde of semi-Westernised lawyers, agitators, bureaucrats, and contractors. It is to be 
hoped that the Indies have once and for all passed the period of spoliation; and there is every indication that the wise and paternal rule of the Dutch, and the lack of enormous urban populations, will for ever be a safeguard against the poisonous growth of a spurious nationalism. But we cannot be surprised if the Dutch, with India and Egypt before their eyes, prefer to proceed with the utmost caution.

BERNARD MIALL. 


\section{CHAPTER II}

\section{GENERALITIES}

I. The importance, area, and population of the Dutch East Indies.II. Administrative divisions of the Dutch East Indies, and the best method of studying them.-III. European, and, in particular, Dutch intervention, in the East Indies.-IV. Physical characteristics of the Archipelago.-V. The races which inhabit them.-VI. The principal languages spoken; and which must be learned by the European settling in the Indies.

I.

THE Dutch East Indies are well worth knowing; they are favoured by nature above most other lands; their present rulers afford a rare example of a political intelligence which is equally tenacious and sagacious, and their system of administration is full of valuable lessons for the other Colonial Powers of Europe.

The kingdom of Holland, or the Netherlands, has an area of 12,700 square miles, and a population of about 5,000,000. Her Asiatic possessions, which lie between $95^{\circ}$ and $\mathrm{r} 4 \mathrm{I}^{\circ}$ east longitude, and $6^{\circ}$ rorth and $\mathrm{I} \mathrm{I}^{\circ}$ south latitude, are known as the Dutch East Indies (Nederlandsch-Oost-Indië in Dutch, or simply NederlandschIndië-Dutch India). These vast colonies are washed on the east by the great Pacific Ocean; on the north by the China Sea; on the south and west by the Indian Ocean. ${ }^{\mathrm{x}}$

- The groups of islands, great or small, which lie between the south-eastern extremity of Asia and the north-western portion of Australia, and of which the Dutch East Indies form a part, are 
These possessions, known sometimes as the Indian or Malayan Archipelago, but more commonly as the East Indies, comprise an approximate area of 698,000 square miles; or fifty-eight times the area of Holland, and nearly three and a half times that of France. Their population is estimated at $37,402,500$ inhabitants, or seven times that of Holland. $x$

These figures have no absolute value, however carefully they may have been determined. The very immensity of the colonial domain, the scattered positions of its various members, obstacles of a geographical nature, and the hostility of certain indigenous tribes in some of the islands, have necessarily resulted in the incomplete or superficial exploration of many regions. Particularly is this the case with the great island of Borneo, of which the Dutch portion alone has an estimated area of 2 12,600 square miles, or seventeen times that of Holland. A more detailed and more scientific examination of the country during the last twenty years has revealed it in quite a new light. The area of Sumatra, which is nearly as large as Borneo, and far more intimately known, is still estimated by some travellers at $\mathrm{I} 79,880$ square miles, and by others at 167,470 .

We must not look for rigorous exactitude in the figures relating to the population; once more, such figures have only an approximate value. We can imagine the difficulty, the impossibility even, of effecting a methodical census of these enormous tracts of land, which are but

usually known in Holland as the Indian Archipelago ; in England, as the Malay Archipelago. In Germany also they are known as the Malay Archipelago (Malayische Archipel); or, following the example of Bastian, as Indonesia, the "Isles of India." In France they are known as the Asiatic Archipelago (Archipel Asiatique), and Elisée Reclus has introduced the graceful title of Insulinde, employed for the first time in the romance Max Havelaar, by Multatuli (E. Douwes Dekker), the famous Dutch author. See Blink, Nederlandsch Oosten West-Indië, p. I9.

30,098,000 for Java and Madura and 7,304,500 for the other Dutch possessions. See Regeerings Almanak voor Nederlandsch Indië, I909, pp. 4-5; census of Dec. 31, 1905. 
imperfectly known, and are often inhabited by peoples whose submission to Holland is purely official. The chief pitfall in such cases is the tendency to deduce the number of inhabitants from the area of the territory; an error which the former explorers were, as a rule, only too ready to commit. Later, by a sort of reaction, the density of the population was estimated at a figure far below the reality. The census, in short, is accurate only in the case of Java; the first island of the Archipelago to achieve civilisation, as it remains the most civilised to-day, as well as the richest and the most densely peopled. In Java, moreover, the Dutch domination is accepted without protest. Java, with its neighbour Madura, has an area of 50,600 square miles, and a population of $30,098,000$; that is, it suntains four-fifths of the total population of the Dutch East Indies.

II.

On account of the various inequalities between the different portions of their colonial empire-inequalities of area, population, and value, both intellectual and economic, as well as inequalities of civilisation-the Dutch have divided their East Indian possessions, from the administrative point of view, into two large departments. The first includes Java and Madura; the second the Outer Possessions, as they are called (Buitenbezittingen), with Sumatra, Borneo, and the other islands; a division far superior to Java in the matter of area, but inferior in population and also in natural wealth, which is often considerable, but as yet is hardly known or badly exploited.

In a book whose object is not only to describe the Dutch Indies from the physical and political point of view, but also to prove their economic importance, it will therefore be best, at the cost of a few repetitions, to study each of these two departments separately, lest we arrive at erroneous generalities. 


\section{III.}

The conquest of so great an empire, and its continued possession for a space of nearly four centuries, is a proof of the admirable racial qualities of the Dutch; qualities which owe something, perhaps, to good fortune. When, in the sixteenth century, they came into contact with Europe, the populations of the East Indies had already been subjected to the influence of two great civilisations: that of the Hindus and that of the Arabs.

The Hindus, about the first century of the Christian era, being doubtless driven from their country by religious persecution, brought to Java and Sumatra their arts, their beliefs, and their social organisation : all greatly superior to those which they found in the islands. They founded several powerful States: Menangkabau and Palembang in Sumatra, and Madjapahit in Java. First Brahmanism, and between the fifth and the sixth century Buddhism, flourished with a vigour which is still attested by the wonderful ruins of Prambanan and Boro-Budur. Towards the thirteenth century (but this date is still uncertain) these faiths were replaced by Islam; brought first of all by Arab and Persian merchants to the eastern coast of Sumatra, and thereafter overrunning the whole Malay Peninsula and the entire Malayan Archipelago, either by means of pacific proselytism or through the warlike fervour of the early Mahomedan states. To this day five-sixths of the population of the Dutch East Indies profess the faith of Islam, in name if not always in fact.

In the sixteenth century the Europeans, known hitherto only in the shape of the Venetians, to whom the Arabs and Persians transmitted the precious spices which were grown in the Indian Archipelago, came at last as a conquering power. First of all came the Portuguese, who, in I 5 II, took possession of Malacca, whence they proceeded to Sumatra, Java, Borneo, and Celebes; and then to the Moluccas, upon which they imposed their suzerainty, with an eye especially to monopolising their 


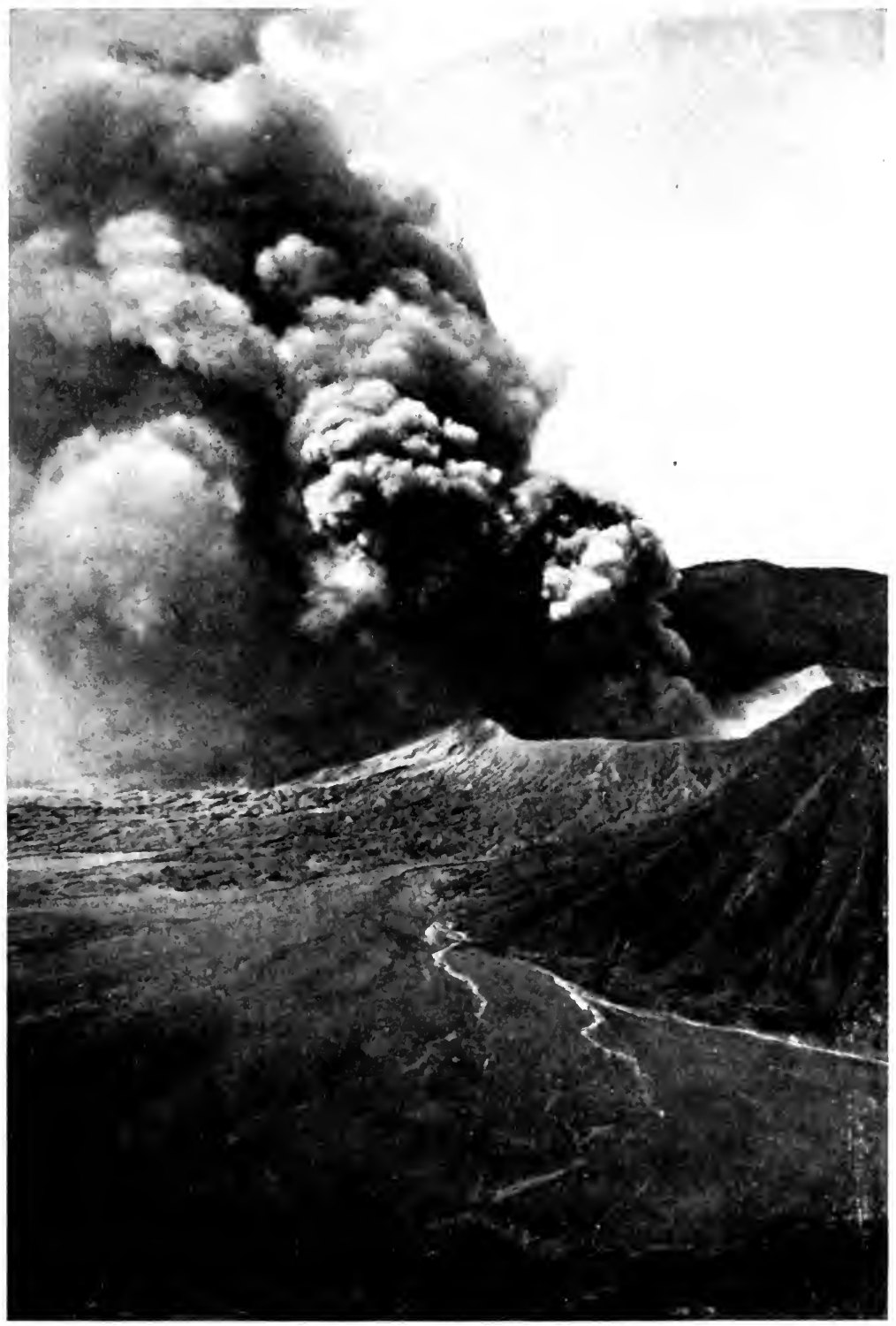

BR(IM() ANI) THE SEA (IF SANI). 

trade. The Spaniards had a footing in the Philippines from 1520 onwards. In $15^{80}$ the union under Philip II. of the crowns of Spain and Portugal resulted in the possession by Spain of all the Portuguese colonies in India and the Indies.

The first act of Philip, once master of Lisbon, was to forbid that port to the Dutch, his sometime subjects, who had revolted in 1572 . The Dutch, the " waggoners of the sea," at this period depended absolutely upon Lisbon, whence they carried the spices of the Indies to all parts of Europe. Stifled in their growing commercial power, they were condemned by this very fact either to disappear from the seas or to go themselves in search of the wealth of the Indies. But the two Iberian nations, who alone possessed the secret of the route, $\mathbf{x}$ guarded it with jealous care. The extremest penalties, even that of death, were decreed against those who should betray the secret. The Dutch resolved to solve it despite all obstacles. Two expeditions, which sought the Indies by way of the Antarctic Ocean, came to a disastrous end, which, in after years, was apotheosised in poetry; but at length Cornelius Houtman of Gonda, who was trading secretly in Lisbon, succeeded while there in obtaining valuable information. Thrown into prison as the penalty, he succeeded in sending to Amsterdam the news of his discovery and his hopes, and of the heavy ransom which alone could set him free. The Dutch merchants immediately clubbed together to deliver him, and, in possession of his secret, founded, with him and his brother, a commercial undertaking known as the Company of Distant Countries (Compagnie van verre); a title as vague and as splendid as their hopes. An expedition left the Texel in 1595, consisting of four vessels and $25^{\circ}$ well-armed men, including Jan Molenaer

${ }^{3}$ Portugal discovered the route by rounding the Cape of Good Hope; Spain by threading the Straits of Magellan. The charts showing the route were given each voyage to the captain of the vessel, and were taken from him upon his return, and had to be kept secret from every eye but his. 
and C. and F. Houtman. It recruited off Madagascar, I and in 1596 landed first in Sumatra, and then at Bantan 2the Bantam of the ancient Dutch and Portuguese traders.

From that time forward expeditions from Holland succeeded one another in the Indian Ocean, with a tenacity equal to their boldness; and Batavia, which was formerly known as Jakatra or Djakatra, was founded in I6I9. Shortly afterwards Holland took advantage of the insufficient defence on the part of Spain of the former Portuguese colonies, and of the violent rupture between the two countries in 1660 , by appropriating the Portuguese possessions which were no longer properly defended; and this in the West Indies and South America as well as in the Malay Peninsula and the Archipelago. Her progress was arrested only by the competition of England, a far more powerful rival. During the whole of the eighteenth century England was disputing these vast possessions with Holland; first in India, then in the Malay Peninsula and the Indian Archipelago. For a time Holland was almost completely dispossessed by her, when the Batavian Republic, later the Kingdom of Holland of Louis-Napoleon Bonaparte, was willy-nilly compelled by Napoleon the First to take a hand in his politics. 3

I F. Houtman compiled the first known Malagasy vocabulary.

2 Houtman was not opposed by the Portuguese; they rather welcomed him as an ally, being then at war with the king of Bantam. In return for their services the Dutch obtained permission to build a factory, which they eventually had to abandon, as their arrogance and brutality provoked the natives, and in the ensuing hostilities they shot down a large number of the latter. Raffles was under the impression that Houtman had been employed by the Portuguese in the East Indian trade. On the way to Bantam the Dutch anchored off Madeira, where the prince wished to pay his respects : but they fell into a panic upon observing the size of his escort, and massacred nearly all. Raffles remarks that even thus early the Dutch exhibited the mixture of haughty superiority and extraordinary timidity and suspicion which characterised all their subsequent proceedings.-[TRANs.]

3 Concerning this period, see O. Collet, L'île de Fava sous la domination française (Paris, 1909, large 8vo). 
The treaties of 1814 and 1815 re-established the House of Nassau on the Dutch throne, and compelled England to restore the Indies. England even renounced her pretensions to Banka in return for the cession of Cochin and its dependencies on the Malabar coast. An understanding was then arrived at between the two nations, India and the Malay Peninsula being completely surrendered to England, and the Indies to ithe Dutch, who in 1824 , according to the treaties of London, abandoned their remaining settlements in India and the Malacca Peninsula, including the island of Singapore, while England abandoned all claims to Sumatra and Billiton. ${ }^{\mathrm{x}}$

In order to become absolute mistress in her sphere of empire, Holland even endeavoured, but without success, to obtain, by sale or exchange, that portion of Timor which was still in the hands of the Portuguese. She did not succeed; but the treaty of 1859 did at least very precisely delimit the frontier between the Dutch and Portuguese portions of the island.

To-day, in the eyes of Europe, Holland is the undisputed mistress of the Indian Archipelago, excepting only the Portuguese portion of Timor and the north-western portion of the great island of Borneo, where the formerly independent Sultanates of Brunei and of Sarawak (the latter founded by the English adventurer famous as Rajah Brooke), and the British North Borneo Company, still occupy wide territories. ${ }^{2}$

IV.

Unity of possession seemed almost a logical consequence of the remarkable geological and physical unity of all the portions of this great empire.

×An island between Banka and Borneo, called also Bilitong, or Blitung.

2 These two Sultanates are to-day under the protection of the English Crown, which recognised the services of James Brooke in the cause of colonial expansion by creating him a baronet. A volume of great interest is "The Private Letters of Sir James Brooke, Rajah of Sarawak, narrating the events of his life, from 1838 to the present time," edited by J. C. Templer, London, 1853,3 vols. 8 vo. 
Despite the disparate sizes of the various islands, and the vast dimensions of some, the Dutch East Indies, from Sumatra to New Guinea, are all of the same geological structure. From east to west is a rampart of volcanoes, far-flung in the arc of a gigantic circle, which crosses the shallow waters of many straits. The various islands are based upon the north on the same submarine tableland, above which lies an enclosed, peaceful sea; while the outward shores are separated from the nearest land by vast abysses of ocean; even from those countries which seem, as do the Philippines, to be closely akin to the islands of the Archipelago. The islands of Sumatra and Java, sloping almost directly from their heights into the profound depths of the southern sea, show to the north a lower seaboard, a coast-line more idented, cut into many bays; but the volcanic soil, brought down by rivers and drifted by the coastwise currents, is slowly filling the harbours and adding to the area of the land.

Nearly all the rivers of importance, moreover, flow into that inner sea, by which Sumatra, Java, Borneo, Celebes, and their innumerable satellites, are united rather than divided.

The rainy seasons and the climate are almost the same in all the islands of the Archipelago; there are, of course, inevitable modifications, but the climate is tropical without excessive variation, and in general may be called equable. The flora and fauna, despite their wealth and astonishing variety, have in all parts a similarity, and at the same time a peculiarity of their own, which does not permit of their attribution to any of the neighbouring countries. Situated between India and Australia, the Malay Archipelago forms a harmonious transition between these two countries. To the west its magnificent fauna and flora possess distinct characteristics which yet recall India; to the east they prophesy Australia, by forms no less varied, often equally strange, and always richer and more abundant. 


\section{V.}

In the matter of the races which inhabit the East Indies, we find a variety of types apparently as great as the variety of the flora and fauna-a variety which has often confounded the ethnologists, and has given rise to many theories. We shall confine ourselves to recalling, in its broader aspects, the theory which appears to us to correspond most closely to the actual facts. We find, in the Indian or Malay Archipelago, of which the Dutch East Indies form a part, four great ethnical groups, of very unequal intellectual capacity and numerical value. These four groups are the Malays, the Indonesians, the Negritos, and the Papuans. The Malays and the Indonesians, by far the more numerous, form the basis of the population of the Dutch East Indies. It is believed that there are Negritos in the archipelago of Rhio and Lingga; but even were they not to be found in the Dutch possessions we ought not to pass them by, since they do exist in the Malay Peninsula, and also in the Philippines, which islands the Dutch East Indies resemble at so many points.

The Papuans (from the Malay puwa-purwa, "who have crinkled hair") are found in New Guinea, and also, to a limited extent, on the islands of Waigeu, Salvatti, and Aru; while groups related to the Papuans inhabit the islands of Buru, Ceram, Kei, and Tenimber, ${ }^{\mathbf{x}}$ and are possibly descended from Papuan slaves. Natives of Papuan origin are also to be found in the Moluccas, Timor, and Flores. It has been suggested that the Kalangs of Java-a race in customs comparable to the gipsies of Europe-might be of Negrito origin; but the suggestion is of no value.

The principal ethnic groups of the Dutch Indies, which do not differ very greatly from one another, consist of the Malays and the Indonesians. The term Indonesian denotes the comparatively pure races which

x Or the Tenimber Islands, or Timor Laut : a group of sixty-six little islands in the Molucca Archipelago. 
inhabit the interior of the large islands, such as the Dyaks of Borneo, the Bataks of Sumatra, and the Alfurs or Alfours of Celebes and the Moluccas. Unlike the Polynesians, who are tall and brachycephalic, the Indonesians are seldom above $5 \mathrm{ft}$. 2 in. in height, and are mesocephalic or dolichocephalic. Both races are yellowskinned : their hair is straight or slightly curling; only the form of the nose, lips, \&c., is slightly different.

The Malays, on the contrary, although slightly taller than the Indonesians (the average height being $5 \mathrm{ft} .3^{\circ} 4 \mathrm{in}$.), and brachycephalic, resemble the latter very closely, but the Malays are a mixed race and in consequence present a much greater variety of types than the Indonesians. If, as is believed, the Malays-by which we mean the Malays proper (of Menangkabau, the Malay Peninsula, and the coasts of many islands), as well as the Javanese, the Madurese, and the Sundanese-are born of the mingling of Indonesian with Hindu, Arab, Chinese, Burman, Negrito, and Papuan elements, then the Indonesians should be the type of pure Malays-the Protomalays, in a word; and this theory appears to be very close to the truth. In Java the Indonesians are deeply crossed with Chinese blood ; the Hindu element is easily recognisable in Bali, Sumatra, and certain portions of Java; and the Arab element is dominant among the Malays of Padang and in Atjeh. In the north of the Archipelago the influence of Negrito I blood is visible, although the signs of Papuan blood are found only in the south-east.

The appearance of the inhabitant of the Dutch East Indies varies according to the ethnic group to which he belongs and his social position. The farmer, merchant, fisherman, artisan, and pirate are not likely to possess the same exterior, the same bearing.

Speaking generally, the Malay or the Indonesian is

× See T. Deniker, Les races et les peuples de la terre (Paris, I900, 8vo), p. 554 et seq. See also the article on Rassen ("Races") in the Encycl. v. Ned. Indië, which contains an excellent exposition and bibliography of the question of the races of the Dutch Indies. 
shorter than the European; he is nearly always thin, but well-built and respectably muscular, with the chest well developed; the joints, hands, and feet are small, giving an impression of strength and suppleness. His skin, of a colour varying from a light ruddy brown to an olive yellow, is usually smooth and hairless; his head is flat and wide, the cheek-bones are salient, and the nose of the "pudding" or "pug" variety; the eyes are slightly oblique, and the large, thick-lipped mouth is ill-concealed by a thin moustache. The hair is very black, and harsh to the touch. All these characteristics, together with a mask of all but impenetrable impassivity, constitute a physiognomy which the unaccustomed European finds disquieting rather than attractive, and of which the finished type is found in the true Malay. It has a certain touch of savagery, of strangeness-a quality which is lacking or attenuated in the Javanese, whose more slender physique attains at times a positive degree of graceful elegance and reveals in every movement their gentler breeding. The Madurese, Sundanese, and Bugis, of more mingled race and more powerful physique, are more like the Malays.

All these various races have a keen intelligence, capable of improvement, retaining the traces of a high civilisation; and under their reticent aspect they are almost always polite and well-disposed towards the stranger.

Although they have never risen to the conception of a great political union, or even the idea of an immense federation of the States of the Indian Archipelago-a state of affairs which would assuredly, in view of the large and warlike populations of many of these States, have closed the Archipelago to Europeans-yet the memory of their past, and their refined susceptibilities, have often rendered the management of certain of these peoples by the Dutch a matter of considerable difficulty.

The most submissive were always the Javanese; the Malays, prouder and more energetic, submit to the yoke with more impatience, and in certain districts (for 
example, Atjeh, or Achin, in Sumatra) they are still desperately struggling to avoid it.

The pride of the Malay seems to derive wholly from his character and beliefs. $\mathrm{He}$ is violent and vindictive; as eager to feel and avenge an injury to his self-respect as is the Japanese, who, according to a recent theory, is a relative of the Malay; ${ }^{\mathbf{x}}$ and his loyalty is reputed uncertain. Moreover, he is a Mussulman, with so ardent and so ancient a faith that throughout the Indian Archipelago Malay and Mahomedan are synonymous terms. $\mathrm{He}$ is conscious of a bitter pride in belonging to a religious community which is, in another fashion, as mighty as the political power under whose domination he lives. A farmer in many places, but more often a sailor, he is famous for his knowledge of the seas of the Archipelago. A trader, and on occasion a pirate, the Malay owes his reputation of extraordinary courage and audacity to his long history of fierce conflicts, and owing to his recklessness and lack of scruples the importance of his position is out of all proportion to his numerical strength.

Extremely courageous, the Malays are also better workers than the Javanese; but, like the Chinese, whose commercial talent they share, though in a less degree, they will often squander the savings of a year on cock-fighting, gambling, women, opium, and haschish. ${ }^{2}$

' See chapter ii. of L'Empire japonais et sa vie économique, by J. Dautremer (Librairie Orientale et Américaine : E. Guilmoto).

2 Our author makes no mention of hemp, attributing the state of amok to opium. This, as is well known, is incorrect; a long period of abstinence from opium causes a peculiar form of poisoning, accompanied by excruciating pains and an unendurable nervous distress of the kind known as "massive"-i.e., felt in every nerve of the body, and especially in the pneumogastric system-a system of nerves of which we are, as a rule, unconscious. This abominable torture is, however, unaccompanied by any delirium or illusions; nor are such caused by opium, despite the vulgar belief, the mind being, as a rule, unusually calm and clear. Indian hemp, or cannabis indica, or the preparation which is used for smoking, is a very different drug. Besides its characteristic reaction upon the nervous system after excess, it produces profuse visions and 
Hemp (haschish), or opium, is smoked by the majority of the natives of the Dutch East Indies, and by the Malays in particular. The smoking of Indian hemp in particular renders the habitué subject to crises of maniacal fury, known by the term amok. This peculiar access of fury is preceded by the most violent depression ; it attacks the smoker suddenly, when he rushes through the streets, armed with his krees, slashing and killing all whom he meets.

The vice of "running amok," which seems to have existed from a quite indeterminate period in the Malayan Peninsula and Archipelago, became so prevalent after the European occupation that the Dutch in the Indies and the English in Malacca finally passed sentence of death upon all natives captured in this condition. The singular diminution of cases of amok which followed leads one to believe that many acts of political or private vengeance were performed under the disguise of this peculiar form of mania.

\section{VI.}

The question of language in the East Indies is almost as complex as the question of races. On account of the multiplicity of tongues, augmented still further by the insular character of the Dutch colonial possessions, which has resulted in the birth of a considerable number of dialects ; we must not prematurely classify them in a genealogical system, or attempt to declare precisely the degree of natural relationship which connects them. Although the time has hardly come for this, the labours of the Dutch linguists have at least enabled us to state that the languages of the East Indies belong to the great

illusions. Readers of the biographies of Omar Khayyám will remember that it was employed by Hassan, the schoolfellow of the poet; to give the novices of his extraordinary sect a foretaste of the Paradise to which their absolute obedience would admit them upon death. The followers of this remarkable religious and political murderer became known as assassins, the term being derived from the name Hassan; hence the word haschish.-[TRANs.] 
Malayo-Polynesian family, or at all events with rare exceptions.

By general agreement they are divided into certain large groups which comprise a series of sub-divisions in the form of dialects.

(a) Group of the Languages of Sumatra.-This comprises Achinese (Atjeesch, the tongue of Atjeh), Gayo, Batak and its dialects (Mandailing, Toba, Daïri, Karo, \&c.), Retjang, Lampong, Simalour, Nias, Mentawei, Engano, and especially the most important of all, Malay and its dialects (the Malay of Minangkabau, or Menangkabau, of Riouw Lingga, Middle Malay, and Mamak).

(b) Group of the Languages of Fava.-This group includes Javanese, Sundanese, Madurese, and their dialects.

(c) Group of the Languages of Celebes and the neighbouring islands.-This group contains many idioms, often confined to a limited district: Sangirese, the languages of Minahasa (Tompahewa, Tondano, Tumbulu, Tonsawang, Tonsea); Bolang, Mongodow, Ponosakan, Holontalo, Mandarese and Kajeli Tomini, Pagouat, Luinan, Kaidipan, Bonol, Tontoli, Malasa, Tara, Barei ; the various Toradjas dialects, Boutonese, Laiwu; Tobungku, Tomsit or Tomini, Banggaja or Peling; and finally Macassar and Bugi, which are far more important than the others.

In order to convey any true idea of the astonishing linguistic variety of the East Indies, we must not fail to mention, in connection with the small islands of the Sunda group, Balinese, Sarsak-Balinese, and Sarsak, spoken on Bali and Lombok; Sumbawarese and Bimanese, spoken in Sumbawa; Endele and Liou, the Mangerese dialects, Paga and Solarais, spoken in Flores; Kupang, spoken in Timor, and Sumbanese in Sumba. In the Moluccas Galelarese, Tarnatese, and various other dialects are spoken; and in New Guinea, Nafor, or Mafor and Jotofese, or the dialect of Jotafa, \&c.I

${ }^{x}$ For further details see H. Blink, Nederlandsch Oost-en WestIndië (vol. i. p. 276 et seq.). K. F. Holle has drawn up a linguistic chart of the Dutch Indies, reproduced in the work cited, vol. i. p. 278. 


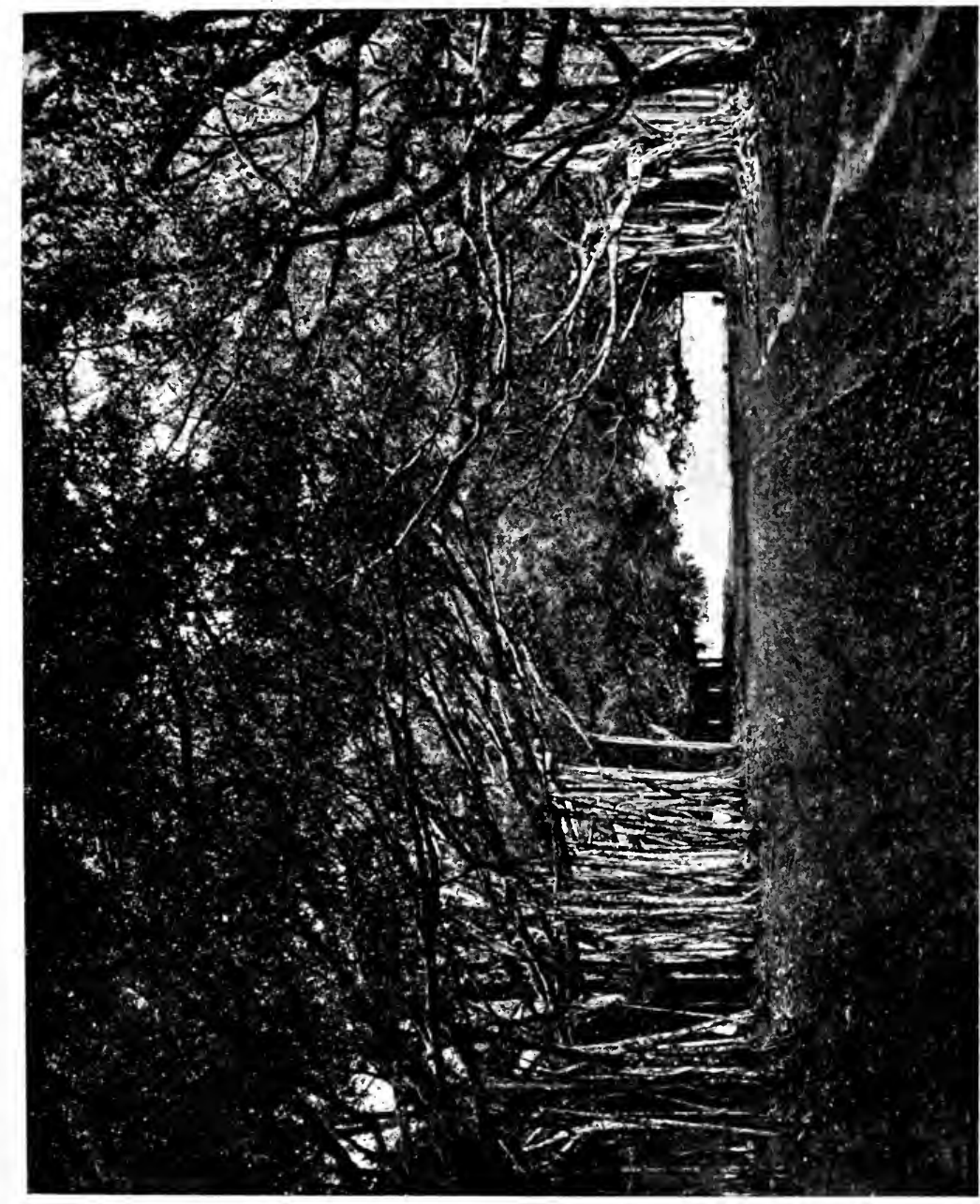




$$
\text { . }
$$


Before this incredible wealth of tongues, which facilitated their conquest of the Dutch East Indies in so far as up to the time of their arrival it had prevented the unification of the different peoples, but which also rendered their organisation more laborious, the Dutch felt the need of an official, administrative language, which should give their great empire at least a semblance of unity. From the time of their arrival they endeavoured to eradicate the Portuguese language, which had already spread through the Archipelago; but they soon saw the futility of trying to impose Dutch. After a few unfruitful efforts they renounced the idea; while during the eighteenth and nineteenth centuries they acted upon quite a contrary principle, taking the greatest pains to prevent the natives from learning their language, with the idea that by such a course they would increase the prestige of the European, the ruler; perhaps also with a view to shrouding in mystery the relative weakness of the Netherlands, in the face of English competition. Malay thus became the official language of the country.

At first sight it would seem that this dignity should rather fall to the Javanese language, which is spoken by more than twenty-four million persons; while Malay is the mother-tongue of some four millions only. Javanese, however, is far from easy to tackle; its grammar and syntax are complicated; it contains modes of speech which vary as one addresses an inferior, an equal, or a superior; with the result that Javanese has never overpassed the limits of Java, nor has it even succeeded in displacing Sundanese or Madurese; while Bugi and Macassar, despite the commercial activity of the people who speak them, have never crossed the limits of their original sphere. The Malay language owes its election, on the other hand, to its extreme diffusion-a result due to its own qualities and that of the Malay race.

It is not only the language of the various Malay groups established in Malacca, Perak, and Singapore, and throughout the whole Peninsula; it is also understood in Sumatra, Java, Borneo, Celebes, Flores, Timor, and 
the Moluccas, and in all the southern portion of the Philippines ; by millions of persons, in short, all of whom belong to rich countries with an extensive trade.

In French Indo-China Malay is spoken by one hundred thousand Malays and Shans; it is the commercial language of the Chinese established in the commercial city of Cholu, and the Hindu merchants who are to be found in almost every part of the extreme Orient. ${ }^{1}$

The widespread use of this language, in comparison with the relatively limited number of Malays, is due to the simplicity, the suppleness, and the harmonious pronunciation of the Malay tongue. It has a great facility of assimilation, so that wherever it has been adopted it has acquired terms borrowed from the dialects which it has replaced. In this manner the conditions of its history have enriched it by a large number of terms from Sanskrit, Hindustani, Arabian, Persian, Tamil, Chinese, Portuguese, Dutch, and English, without speaking of its debts to the tongue of the Indian Archipelago, Javanese, Sundanese, Madurese, \&c.

We may discriminate between two kinds of Malay. One is the literary language, which is written in Arabic characters ; a refined, subtle language, full of fine shades ; a ceremonious, dignified language, as difficult to learn as any other Asiatic tongue. The other is the "low Malay," "vulgar Malay," or laag-maleisch, as it is known in the Indies; a language sufficing those who are dealing with ordinary matters, enabling them to travel everywhere without an interpreter, and to converse intelligibly

I The Chinese in the various ports of the China Sea, coming from provinces where different dialects are spoken, or who, having left their country in childhood, have forgotten their mother-tongue, all use Malay in speaking among themselves. In Hongkong a newspaper in Malay has even been started for their benefit : the Pembrita Tjung $W a$ (Chinese information) intended to give them news of China, and also the translations of official decrees, \&c., which are likely to interest them. In Java the Malay journals for Chinese readers are very numerous, and are read chiefly by merchants and traders. 
with the natives: this may be acquired in a few months. It goes without saying that this language, which is more or less artificial, has only a remote resemblance to the language which is spoken among themselves by Malays of good education. The former is to the latter what French of the "savvy-voo" order is to the French of the Academie. But any one who wishes to acquire prestige among the natives or the notables cannot afford to dispense with correct Malay, or the knowledge of the slightly modified Arabian character in which it is written, although Europeans are gradually more and more inclined to transcribe the Malay literature in Latin characters, as are the authors of the numerous books in Malay which are always appearing in the Indies on all kinds of subjects.

Malay is the language of the Chinese merchants, who hold the whole retail trade of Java in their hands. The prospectuses and announcements of all kinds of the commercial firms and navigation companies are issued in Malay. European products (perfumery, pharmaceutical specialities, \&c.) must always be provided with a prospectus in Malay if they are to find a place on the market.

As the Dutch on their arrival found that the Malay language had been established throughout the Indian Ocean for centuries they imposed it as the official language upon their European officials as well as upon the natives. At the present time all examinations imposed upon colonial officials of European blood demand a knowledge of Malay as an obligatory subject, as well as a second native language, which is left to the choice of the candidate. The reports of the central authority and of the native chiefs are couched in Malay; the language is taught in all the schools of the colony, and in order to avoid the greater difficulties of Javanese, many of the Javanese notables carry on their personal and mutual correspondence in Malay. Finally, thanks to the missionaries who preach in Malay, its diffusion is as rapid in Menado as in the Moluccas. 
In our days, since the victories of Japan and the Young Turkish revolution, the entire Far East seems awakening to a new life. It is demanding the right to come out of the shadows; and the native élite, which has been formed by European culture, is making its voice heard in the Dutch East Indies. It demands, above all, two things : that it shall be granted facilities for learning the language of its masters, the better to assimilate their civilisation; and that a more prominent place shall be given to the Javanese language, on account of its numerical importance. The Government has accordingly inscribed Dutch upon the programme of its principal schools for natives; but as the knowledge of the language is rather a means for the wholly nationalistic claims of the natives, rather than an end in itself, it is hardly probable that it will ever become the official language of the Duch East Indies. If, on the other hand, having regard to the importance of Java, a knowledge of Javanese on the part of the European officials were eventually considered almost as necessary as that of Malay, the difficulties which it presents to the non-Javanese would long continue to prevent it from supplanting Malay.

At the present time Dutch is spoken in the East Indies only by the colonists, among themselves and in their homes. Useful as the knowledge of Dutch may be, the traveller may perfectly well replace it by a knowledge of English, or preferably of French, which is in common use in good society. But in respect of the native element, or even of the foreigners-Arabs, Japanese, Chinese-the traveller cannot afford to dispense with a knowledge of Malay if he wishes to settle in the Indies, or merely to derive all possible profit from a journey undertaken simply for pleasure and instruction.

The duration and the relatively pacific history of the Dutch domination in the Indies is due very largely to their talent for organisation. Having entered the Archipelago with one aim only, and that a practical and commercial aim, they did not allow themselves to be seduced 
into the Imperialism of the Spaniards or the Portuguese, and never exhibited any desire to impose their own faith and mentality, to say nothing of an extreme subjection as well, upon the peoples of the Archipelago. They were too wise to arouse the fanaticism of the Malays and Javanese by an imprudent proselytism; nor did they make the mistake of remaining indifferent in face of the religious ideas of less civilised peoples. All the native faiths were protected by them with absolute justice, unless they were absolutely inimical to their power. For a long period they kept a very keen eye upon the preaching of the Gospels in the Indies, in order to control the excessive and irritating zeal of certain missionaries, and avoid any religious upheaval; even to-day the latter are allowed persuasion as their only weapon, and the authorities preserve a wholly politic neutrality in religious questions.

Again, they have made no attempt to cover the whole of their immense possessions by the network of a factitious administrative uniformity.

They have felt, in the midst of these many populations, with all their diversity, the impossibility of such an undertaking, and have, with very good sense, made use of the political institutions of the natives, whenever such were not too obviously hostile to their effectual domination. Moreover, side by side with territories administered by themselves, they have retained a number of other territories having at their head a sultan or a rajah; these they left on their chairs of state, and beside the representative symbol of authority, who calms the national susceptibilities of the natives, they have set a European official, whose duty it is to watch over the nominal sovereign, and on occasion prompt his actions.

Their purely economic ambition has not always, it is true, saved them from certain regrettable actions of cupidity, or tactless oppression; the methodical devastation of the spice-trees on the Banda Islands (I62I), and the semi-extirpation of its inhabitants, in order to aintain the high market value of spices by restraining 
their production, were actions hardly calculated to endear them to the natives; and in the nineteenth century the system of forced labour, having for some years enriched Holland at the expense of her colonies, came near to bringing total ruin upon the latter, and alienating the loyalty of the natives.

It is none the less true that the Netherlands, endowed with these magnificent possessions, where the climate is equable and labour abundant, have, by means of an able and prudent administration which has lasted more than three centuries, increased the wealth of their colonies tenfold, without either decimating or bastardising the native races.

Admirably situated between the Indian Ocean and the China Sea, a point of union between the East and the Far East; blessed with a subsoil rich in petroleum, coal, silver, gold, and tin; with a soil fruitful in rice, sugar, coffee, tea, quinine, and indigo; with well-equipped ports; with 3,I80 miles of railways and tramways (a figure that will shortly touch 3,490 ); with a trade which, in I906, amounted, in respect of imports, to $£ 23,655,699^{\circ}$ and in respect of exports to $£ 25,910,803$, the Dutch East Indies are to-day not merely one of the finest colonial possessions which Europe possesses in Asia, but seem destined to play a great part in the economical and political struggle for supremacy in Asia to which Europe and the East have been parties since the eighteenth century. 


\section{CHAPTER III}

\section{JAVA AND MADURA : PHYSICAL GEOGRAPHY}

I. Their shape.-II. Their geological constitution and orographical aspect.-III. Streams and rivers of Java and Madura; their qualities as alluvial agents, and their insufficiency as waterways ; their influence upon the coast-line and the harbours.IV. The climate: its stability.-V. The Javanese flora.-VI. The Javanese fauna.

\section{I.}

JAVA and its annex, Madura, are in the form of a long quadrilateral, the area being 50,440 square miles, of which the axis is, in its eastern part, slightly inclined towards the north. By its situation in the centre of the Indian Ocean, which places even Sumatra and Borneo, two very much larger islands, in a certain position of dependence; by the richness of its soil, the abundance and variety of its flora and fauna, the activity, intelligence and civilisation of its inhabitants, and the beauty of its landscapes, Java remains the pearl of the Orient. Although in the matter of dimensions it holds only the fourth place, on the other hand it contains three-fourths of the population, and is responsible for four-fifths of the entire production of the Archipelago.

Java has often been compared to its equatorial counterpart, Cuba, whose area, shape, and orientation are perceptibly like her own ; but Java, by itself, is more thickly populated and more wealthy than Cuba and all Central America together. 
II.

The long and methodical explorations of which Java has been the object for a space of several centuries have made it one of the best-known countries in the world. But although described by Valentyn, Marsden, Raffles, and Horsfield, the determination of its geological formation in a really scientific fashion was commenced only in I820, or thereabouts, under the auspices of the Company of the Indies, and thanks to the zeal of numerous scientists such as Horner, Schwaner, and Macklot. In I840 a new period opened, which is dominated by the celebrated name of Franz Junghuhn, who for many years was incessantly travelling through Borneo, Sumatra, and in particular Java, almost all of whose volcanoes he climbed in succession. He even died in Java, leaving behind him the memory of a life-work admirably performed, and the most valuable observations as to the geological structure of the East Indies. Finally, in 1880, with the advent of the first mining engineers, whose aim was severely practical, a series of fresh observations was commenced, which were at first confined more especially to Banka, Borneo, and Sumatra, but soon spread to Java, and finally furnished an exact description of the latter island. The most eminent name of this period is that of R. D. M. Verbeek, whose important geographical and topographical works are well known.

Java belongs to the great Malayan curve, which starts from Burmah, runs down the Peninsula, traversing Sumatra and Java, and finally turns to the north-east, piercing Santal Island and Timor, and reaching New Guinea through Ceram. Tertiary formations play a great part in the geological constitution of Java, despite the belief that formerly obtained; and the same is true of Borneo and Sumatra. More ancient formations are found in Java, in the shape of cretacean strata, but no fossils are found, excepting in Borneo, which antedate the tertiary period.

The volcanoes which are still so characteristic of the 
Archipelago, and of Java in particular, belong to the quaternary period. They seem to have manifested an alarming activity since the dawn of the historical eraan activity which some retain only too fully for the security of the neighbouring inhabitants. Already more than 90 are known in Sumatra; in Java there are more than I40. In these two islands the degree of volcanic activity is greater than anywhere else on the face of the earth; while the other islands of the Sound, and, to a less degree, Celebes and the Moluccas, are all well provided with volcanoes; indeed many of them, and amongst others Banda, in the Moluccas, are merely the fragments of ancient craters.

Java, whose southern coast-line rises almost perpendicularly from the tremendous depths of the Indian Ocean, sinks in far gentler slopes towards the inner seas, where a submarine tableland, which lies at no great depth, unites it with Borneo.

The coast of Java is rich in bays and inlets; but the shelter which they afford is naturally safer on the northern shore, which is lined by a girdle of islandsthe Thousand Isles (Duizend-Eilanden), the Karimondjawas, the Solombos, and so forth; which are like so many vast bouquets of flowers and foliage cast down upon the threshold of this magnificent country.

The entire backbone of the long island, so graceful in shape as compared with Borneo, or even with Sumatra, is formed by the chain of its volcanoes. Volcano upon volcano, from west to east, they stretch from end to end of Java. They stand in sequence rather than in a series; there are groups of three, or it may be four together, enclosing between their flanks narrow and verdurous valleys; or they rise in isolation, leaving between two summits plains of fifty or sixty miles' breadth, which are commonly of incomparable fertility. There are lakes among them here and there, but these are rare as compared with those of Sumatra.

The most famous of these volcanoes are in the eastern portion of the island; the Salak, not far from Buitenzorg, 
which is visited by numbers of tourists; its neighbour the Gedei (or the Great), some 9,700 feet high, whose summit is crowned with hot vapours and its flanks with magnificent vegetation. This volcano may be seen from Sukabumi, and is connected with Pangerango, whose wooded flanks are topped by a wide terrace nearly eight miles in circumference. The traveller who does not fear the quite endurable fatigue of the ascent may behold, from this terrace, one of the most beautiful panoramas in the world : on all hands are the fertile plains and valleys of Java, full of a wonderful cultivation and sloping gently northwards down to the Javan sea, while to the west and south they fall to the Indian Ocean. Then follows Patuha, whose deep-seated activity is continually betrayed by audible rumblings; Papandajan, or the Forge, the seat of continual uproar and eruptions of jets of steam ; Gunung Guntur (Mount Thunder), whose grey, bare mass, rising from an ocean of verdure, seems to reveal its deadly temper ; and Galunggung, whose eruptions are still more disastrous, although its aspect is less forbidding.

After the last-named volcano the series breaks up into a country of plateaux of inconsiderable height, until the high plain of Bandung is reached, around which are grouped Burangrang, Tangkuban Prahu, and Tampomas. Distant and remote, in an isolation increased by the majesty of its wooded slopes and its ever-smoking crater, rises Slamat, which stands, as it were, a sentinel between the volcanic groups of the west and the centre of the island. Among the latter are Rogo Djambangan, Prahu, the magnificent Sindoro, Sumbing, and Merapi, which rise in the neighbourhood of the tableland of Diëng, from which the spurs of Prahu rise. To the east of Merapi is Gunung Sewu, or Duizendgebergte (the Thousand Mountains) whose valleys are so fresh and fertile that their ideal beauty is famous throughout the island.

To the south of Surabaja the series of the eastern volcanoes begins with Gunung Kelut, or the Broom; then comes Kawi, then Ardjuna, of the many crests; then 


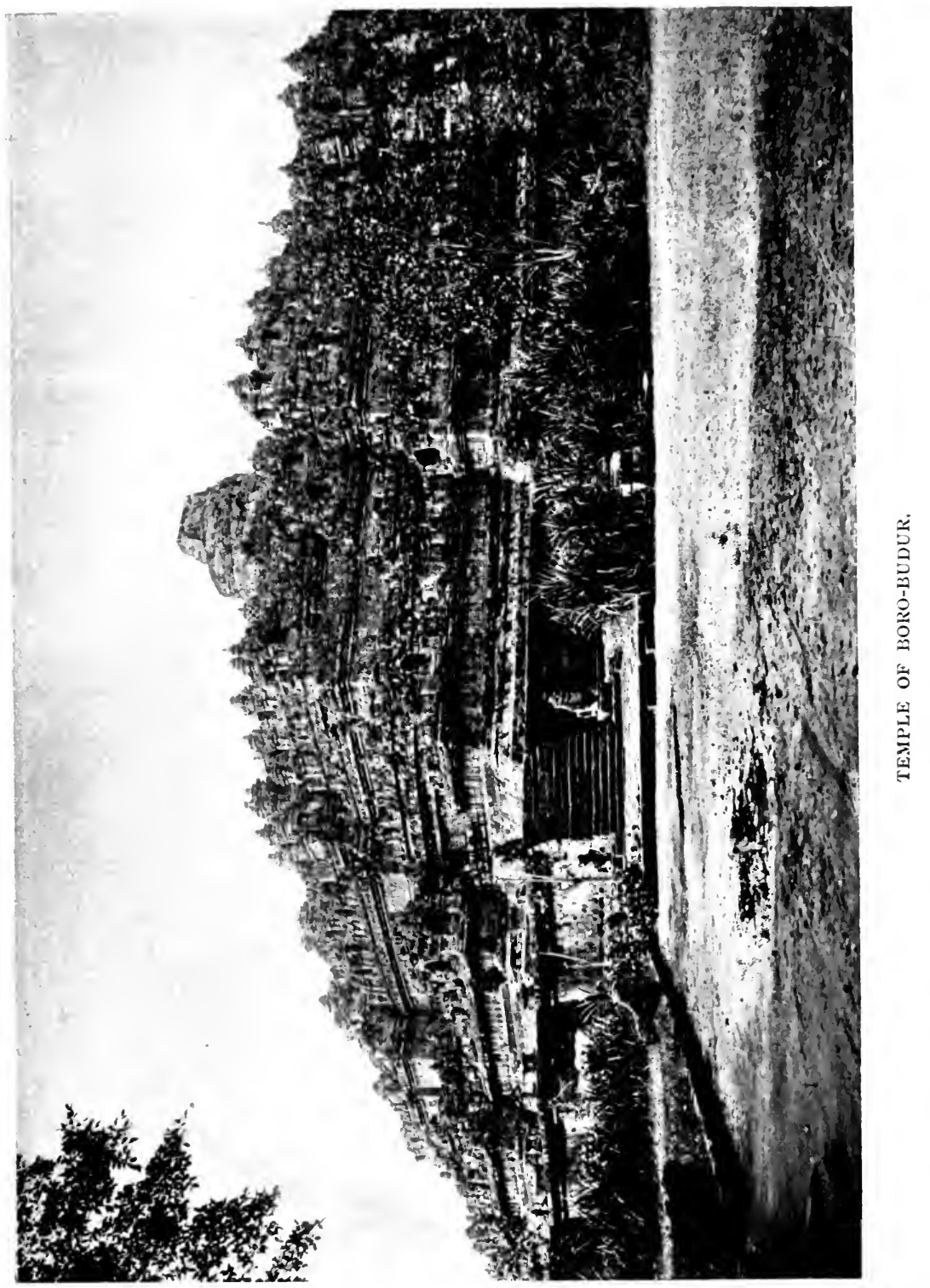



Tengger, and Semaru, the highest peak in Java ( 12,300 feet). In this region was established of old the famous Indo-Javanese kingdom of Madjapahit, which succumbed, at the end of the fifteenth century, or early in the sixteenth, to the armed proselytism of Islam; but the vanquished faith held out for years on the volcanic slopes to which its last professors fled, and left behind it not only the ruins of many remarkable Hindu temples on the Diëng tableland, but a long-enduring memory in the mind of the people.

The volcanoes, which have greatly contributed to the physical integrity of Java, by emitting, in the shape of lava, cinders, and the alluvial ooze of the many rivers, the material of the many islands of which it must once have consisted, have no less added to its beauty. Their majestic outlines, their mighty flanks, clad with the densest foliage, or, more rarely, rising stark and bare, crowned with clouds of burning vapour, seamed with a thousand streams and geysers, all multiply the vivid charm of the plains and valleys, rich in the bright vegetation of the coffee plantations or the spreading rice-fields. Moreover, the volcanoes, on account of their thermal springs, their mountain stations, and the sanatoria built upon their lower slopes, and, above all, on account of the extraordinary fertilising power of their ejecta, are still one of the leading elements of the material prosperity of Java. It is at the foot of the most famous volcanoes that the most flourishing crops are found.

It is true that they are also at times a terrible cause of ruin and devastation. Although Salah has not been in active eruption since 1699, Papandajan, whose voice is still heard at a distance, broke out into an eruption in $\mathbf{I} 77^{2}$ which swallowed up whole villages; and Gunung Guntur, or Mount Thunder, has on several occasions destroyed more coffee plantations than it has fertilised. It is recorded that in 1843 , during a slight eruption, the sun was hidden for half the day, while ten million tons of dust were thrown I0,000 feet into 
the air; while Galunggung, in 1824 , covered with a tide of boiling mud more than II4 villages, and thousands of natives; while Lamongan and Raoun, on the shores of the Straits of Bali, to cite only the more notable volcanoes, have shown themselves equally formidable. Such eruptions as those mentioned not only destroy villages, natives, and crops, but also make the land a desert for many years; for beasts of prey howl amidst the ruins, and when the forests have reconquered the spurs of the volcano they take up their abode in them, thus greatly adding to the difficulties of re-establishing civilisation. The Gedei is subject to alternate earthquakes and eruptions, and the former, the result of its subterranean upheavals, are perhaps more terrible than the latter. The last, in 1879 , destroyed Sindanglaja, the sanatorium, and the neighbouring villages.

The mountain system of Madura is only a subordinate continuation of that of Java. Although the island is generally hilly, the highest summits, such as Tambuhu, do not exceed I,200 or I,300 feet.

\section{III.}

The hydrography of Java arises from the volcanic character of its orography; water is abundant, but the streams are torrential, and their courses are determined by the enormous median mass of the mountains.

Those to the south, being more closely confined between the volcanoes and the coast, which dips abruptly into a deeper ocean, are too short and too rapid to be easily navigable. But those of the north wind across the wide plains, which slope more gently to the coast, and empty themselves into the enclosed waters of the Archipelago, which, calmer and shallower than the Indian Ocean, are slowly completing the work of the volcanoes, which, having created Java by the junction of many islands, tend incessantly yet further to increase its area. The detritus carried by the rivers to their bars or deltas, together with the overflow of lavas 
and ashes, and the reefs of coral which emerge at every eruption, increase the area of the island imperceptibly but continuously, diminishing the bays, transforming the islands into peninsulas, but silting up the mouths of the rivers and the best harbours on the coast.

These rivers, which in Javanese bear the name of kali, and in Sundanese that of $t j i$ or tchyi, had to be greatly improved by dredging, embanking, \&c., before they were of any use for navigation. Naturally enough, this work was commenced in the neighbourhood of Batavia, where the Dutch had first established themselves; and the many narrow water-ways of the province and city of Batavia were the first to be rendered navigable. But we must look to the eastern portion of the island to find a river really worthy of the name: the Kali Solo, brimming with the waters which descend from Merapi and Merbahu, and navigable by boats of considerable size over its entire length of 3 ro miles. Its magnificent estuary would be accessible to large ocean-going vessels were it not obstructed by gigantic sand-banks.

The same drawback affects the other large water-way of the northern slope of Java, the Kali Brantas, which debouches to the south of the Strait of Madura. It is wide, with an abundant flow of water, but so impeded by mud and sand that no large vessels can make use of it.

The rivers of the southern slope would be even less navigable than those of the north, had not the Dutch undertaken works of canalisation-to such effect that the wide estuary of the Tji (or Kali) Tanduwi, or Tanduj, is open even to steamboats. But will it permit of their entry much longer? Scarcely, without human intervention; for it is filling, day by day, with its alluvial wealth, the large gulf known as Segara Anakan, the Sea of Children or Kindzee; and little by little its muddy deposits are annexing the island of Kembangan, once far from the coast, but now connected with the mainland.

The shores of Java suffer from the same trouble; full of wide bays or inlets, especially on the northern side, 
the double action of volcano and river is daily tending to fill their depths ; in the course of time they disappear, while new bays and inlets are formed by the annexation of coastwise islands by the incessant outward movement of the shoals. Hence the shores of Java are only too often bordered by long stretches of muddy shoalslagoons whose treacherous islands, covered with rank foliage, are noisome with swamp miasma, and the breeding-ground of deadly fevers.

\section{IV.}

The climate-or, we might say, the climates of Java, for it varies according to the height and aspect of whatever part of the island we consider-is like all tropical climates. It is at once moist and hot; for Java lies in the zone of the trade winds, the belt of alternate monsoons. One, the "good monsoon," or the dry season, lasts from June to September ; the other, the "bad monsoon," or the rainy season, lasts from December to March. The best t'me for the traveller to land in Java is the month of April or May.

The chief peculiarity of the climate of the Indies, and of Java in especial, is the equability of the temperature all the year round. In Batavia the thermometer marks an average of $79^{\circ} 5^{\circ}$ from June to October, or the period known as the hot season, but during the cold season, or in January and February, it very rarely falls below $77^{\circ} 4^{\circ} \cdot{ }^{x}$

It is far less damp in Java than in Sumatra; but it is damper in the western than in the eastern portion of the island, whence the vegetation in the former is infinitely

× In Batavia the highest average temperature is recorded in September $-79^{\circ} 45^{\circ}$-and October-79.66. The average for the whole year is $78.8^{\circ}$. The absolute maximum recorded was reached on the 6th of November, 1877 , at one o'clock in the afternoon- $96 . \mathrm{I}^{\circ}$; the absolute minimum on the 9th of August, 1877, at six in the evening- $66^{\circ}$. (Observations made between 1866 and 1900, cited by Blink, Ned. Oost-en West-Indië, vol. i. pp. 127, 132.) 


\section{JAVA AND MADURA}

more luxurious than in the latter. As the islands of the Archipelago approach Australia their climate becomes always drier and their vegetation less exuberant than in the neighbourhood of the peninsula and India.

The range of temperatures, already small in Batavia and the western plains, becomes still smaller in the interior, and is noticeable only on the heights, where the rains are of almost daily occurrence and the thunderstorms of tremendous violence and extraordinary frequency. There, or at least in certain localities, the thermometer rarely rises above $80^{\circ} 6^{\circ}$ in the daytime, while at night it ranges between $57^{\circ} 2^{\circ}$ and $60^{\circ} 8^{\circ}-\mathrm{a}$ climate which puts life into those depressed by the anæmia of Batavia and the large towns of the coast, and which, helped out by the beauty of the surrounding landscape and a little, perhaps, by comparison, is qualified as delicious. Such a climate is found in Sukabumi, Bandung, and Garut in the west, and in Malang in the east. It is this climate which has led the Dutch Government to establish a number of sanatoria at Sukabumi, Sindanglaja, and Tegal-laga, near Bandung, in the Preangers; at Pelantungan, in the neighbourhood of Samarang; at Tosari and Puspa, in the residency of Pasuruan. These establishments, the like of which are sadly lacking in French Indo-China, allow the colonists and officials suffering from dysentery, liver complaints, fevers, \&c., to recruit themselves. One of them, that of Tosari, is the only spot on the island which is absolutely free from malaria.

\section{V.}

The splendour of the Javanese vegetation has been celebrated for centuries and in many strains. Thanks to the situation of the island beneath the Equator, which ensures the privilege of perpetual summer and unfailing rains; thanks to its high mountains, which break the winds, condense the clouds into moisture, and, having fertilised the soil with their lavas, refresh it with life- 
giving waters, the flora of Java is as rich as it is varied. It may be seen under many aspects, accordingly as one explores the shores, the plains, the first slopes of the mountains, or their heights. Along the coast grows the dwarf-palm, or Nipa fruticans (Wurmb.), whose leaves $(a t a p)$ serve to thatch the huts of the natives; the beautiful Maripa palm (Attalea maripa Mart.), the cycadeus, and the pandanus. In the plains and the foothills of the ranges, side by side with the carefully cultivated foodcrops, which the labour of man obtains from or imposes on the soil, and of which there are many not native to the Indies : side by side with the fields of rice, the plantations of coffee, quinine, cinnamon, cotton, sugar-cane, pepper, tobacco, vanilla, and tea, grow the pisang, or banana-tree, the coco-palm, the aren or sugar-palm, $\mathbf{x}$ the fan-palm, the lontar, or Borassus flabelliformis L., a cousin of the date-palm, and the rattan (Malay, rotan), or climbing palm; in short, all the family of palmswonderful not so much by reason of the number of their varieties, which barely exceeds three hundred, as on account of their grace and the charm which they add to the landscape, and, above all, the many ways in which they are of service to the natives. The most useful are the sago-palm (the Malay Pohon sagu=Metroxylon sagus Roxb.), with its nourishing pith, the sugar-palm, and the toddy-palm, ${ }^{2}$ known by the name of their precious gifts. Besides the palms we must mention the bamboo, a plant so necessary that we cannot imagine the life of the inhabitant of the Far East without the constant assistance of the bamboo, which is put to a hundred uses; and the great figs, or banyans, of which one variety-the Ficus benjaminea L. (Malay, beringin, beraksa; Javanese, waringin)-puts forth such a multitude of hanging roots from its trunk and branches that one individual tree will

- The Javanese name for the Arenga saccharifera Lab., the sap of which produces the aren sugar, so appreciated by the Javanese.

- Palm wine and palm sugar are furnished by the following species: Arenga saccharifera, Borassus flabelliformis, Cocos nucifera, Nipa fruticans, \&c. 
constitute a whole grove by itself, so large is the space which it covers and shelters; the Altingia excelsa, which produces the resin known as liquid amber (in Malay, getah rasamala) which is used in medicine, and grows sometimes to a height of 160 feet; enormous tree-ferns; myriads of lianas, so long, strong, and supple that the natives often throw them across rivers or ravines to serve as bridges, while the trees caught in their embrace quickly die of strangulation.

On the slopes of the mountains, at a greater altitude and in a lower temperature, the traveller will be surprised to see, in juxtaposition with the wonderful products of the tropical flora, a large number of trees which are known to our temperate climate. The king of the Javanese forest, the Tectona grandis L., the djati, jati, or teak, whose close and almost impenetrable grain makes it of the greatest value in shipbuilding, may be seen growing next to the oak, the maple, the lime, the ilex, the chestnut, and the pine. Above the height of 6,500 feet these are replaced by thickets which grow sparser and greyer as the belt of heat without moisture is reached, but after the rainy season one may find on the flanks of the volcano the violets and buttercups of the West. But one also finds venomous plants unknown to Europe; among others the antjar, or Antiaris toxicaria, of Seschenault, and the famous upas, whose mortal effects have been celebrated by the poets. Even in the briefest sketch of the flora of Java one must mention the graceful nepenthes and the gay begonias, which have long since been acclimatised under English skies.

\section{VI}

The fauna of Java is even richer than those of Sumatra and Borneo, with the easily appreciated difference that it is less formidable to man. Java can boast neither of the elephant, nor the tapir, nor the orang-outang, but it still contains a certain number of rhinoceros, black and spotted leopards, and-especially in the centre of the 
island-there are tigers, whose ravages are still considerable. Lightning and the tigers are the two greatest terrors of the Javanese; he speaks of them only with fearful respect; their victims amount to hundreds each year : yet the natives abstain from any systematic campaign against the tigers, despite the terror which they inspire, because the destruction of the tigers results, in their experience, in the advent of herds of wild pigs, which ruin the crops. The great wild bull, or banteng (Bos sondiacus, M. and Schleg.), is still found in Java; there are no less than four varieties of pig, immense herds of deer and of antelopes, and the wonderful East Indian fawn, the dwarf deer, or mouse deer, the most graceful little creature on the face of the earth. Among the domestic animals we must mention the buffalo, or kerbau, the bullock (sapi), the pig (babi), the goat (kambing), which is found in the most miserable kampongs (villages), the sheep, the dog, and the cat.

The birds of Java, many of which are clad in the most brilliant plumage, do not number more than 270 species, of which forty are peculiar to the island. Ducks, and the wild cock, peacocks, pigeons, and pheasants abound, not to speak of the kingfishers, parakeets, ant-eaters, and birds of paradise. The peacock is the object of a certain amount of aversion, because the natives believe that a troop of peacocks reveals the approach of the tiger, whom they follow in his hunting. ${ }^{\text {I }}$

The dugong and the cachalot are often seen along the coast; crocodiles also are common, and the rich vegetation of Java conceals a great variety of snakes, many of which are far more dangerous to man than the dreaded tiger.

The aquatic fauna, whether marine or otherwise, is extremely rich, and for the native is an important source of food and prosperity, as we shall see when we come to study the native's life.

I It is supposed by the Javanese that the peacock eats the intestinal worms of the tiger's victims. 


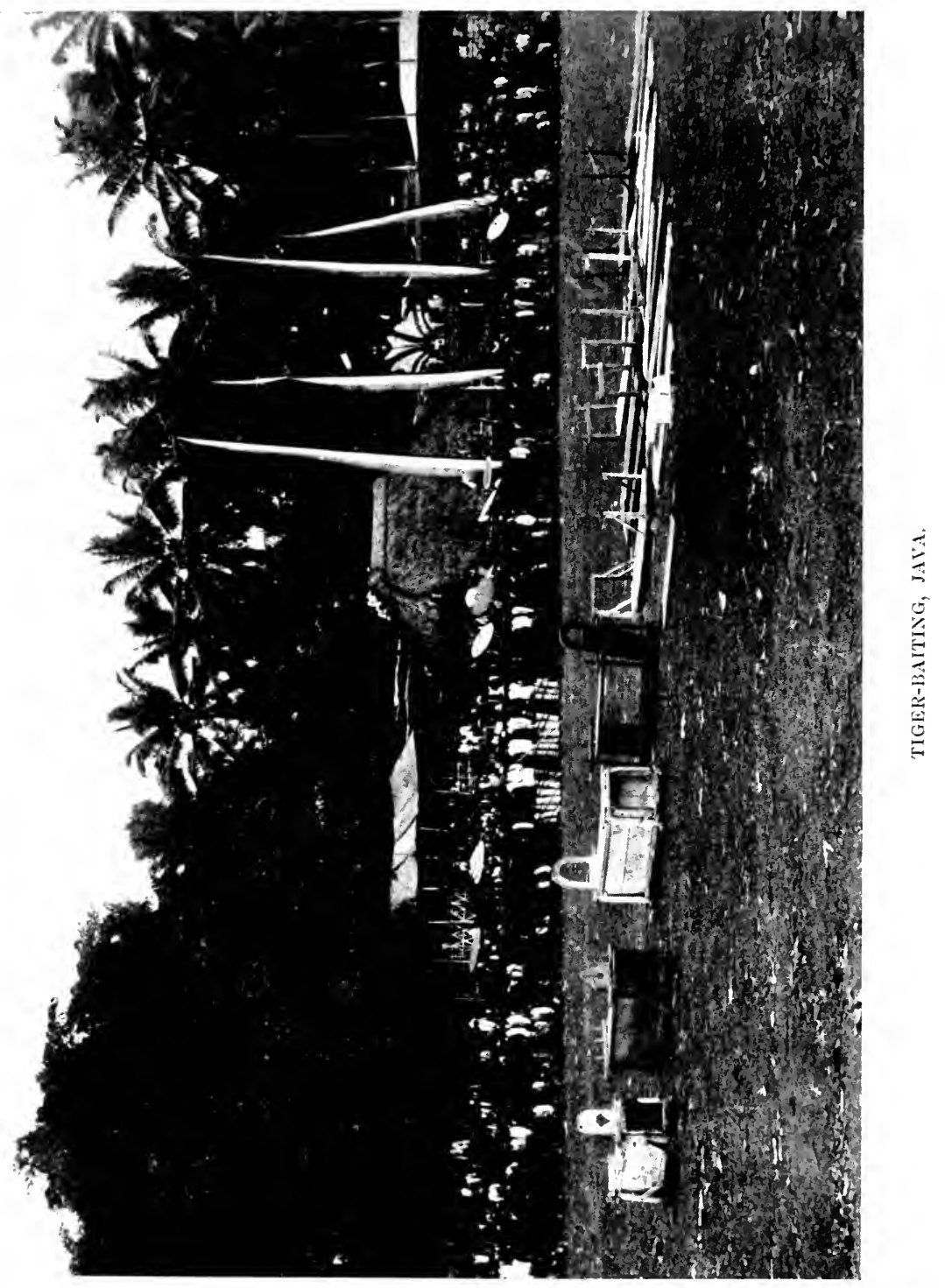





\section{CHAPTER IV}

\section{ADMINISTRATIVE DIVISIONS OF JAVA}

I. The seventeen Residencies.-The western Residencies: Bantam, Batavia, Cheribon, the Preangers.-II. The central Residencies : Pekalongan, Samarang, Banjumas, Kedu.-III. Kedu and BoroBudur.-IV. The Vorstenlanden, or Principalities, Surakarta and Djokjakarta.-V. Rembang, Madiun.-VI. The Residencies of the East : Surabaja, Kediri, Pasuruan, Besuki, and Madura.

I.

THE immense area of Java and Madura was, until I9oo, divided into twenty-two Residencies or Provinces, which have since been reduced to seventeen; partly as a measure of centralisation, but still more as a matter of administrative economy. Two of these, in the centre of Java, have retained an apparent independence; one under a Susuhunan, $\mathbf{x}$ and the other under a Sultan. These are known as the Vorstenlanden, or Principalities: Surakarta and Djokjakarta.

The first Residency in Java, starting from the western extremity of the island, is that of Bantam; which, after having been the most flourishing of all, is to-day perhaps the poorest. Bantam, the capital of the old Sultanate of Bantam, was indeed the centre of the Dutch power until the foundation of Batavia, being better situated, at the crossing of the maritime highways, and having a better protected road-

- Or, being abridged, sunan. A title which, in ancient Javanese, more or less precisely signifies "his Holiness"; it used to be given only to princes who united in their hands both the spiritual and the temporal powers. 
stead. Bantam, for nearly fifty years, was the great European port; to-day it is only a poor native town, living by a small trade in fruits and agricultural products with Batavia, and, on the other side of the strait, with its Sumatrese neighbours of the Lampong country. Of the strangers who visit the city many, if they are Malays or Mahomedan Chinese, go there out of veneration for the ruins of the ancient mosque, and the tombs of the Imams; while the Europeans bestow a glance on the ruins of the seventeenth-century factories, or the memorials of the first pioneers of European civilisation, who sleep in a cemetery as green as a garden. For a few years Anjer succeeded Bantam as the centre of the Dutch trade and life; in I883 it was devastated by the so-called tidal wave which followed the eruption of Krakatoa, and was unable to recover. Even the seat of the Residency was moved to Tjilegon, and the supremacy of Bantam passed to the neighbouring province.

This was only reasonable; for the Residency of Bantam contains only 850,000 inhabitants, while that of Batavia counts nearly $2 \frac{1}{2}$ millions. Batavia-and the city seems to be gradually absorbing the province-is still, despite the efforts of Surabaja and Samarang, the capital of Java, of the whole Dutch East Indies, the essentially European city. It owes less to its climate, which, owing to the low altitude, is only too often stiflingly hot, or to the beauty of its landscapes, which must be sought at Buitenzorg, some twenty miles inland, and which are inferior to those of the Preangers, than to the plexus of human lives which it has somehow gathered about it; the picturesqueness of its old quarters ; the gay splendour of the new city, and its background of more than a century of European civilisation.

Batavia is no upstart; it has its aristocratic quarters, its old traditions, which date back to the year I619, when the Dutch built the city upon the site of the native Djakatra. To-day it spreads out for a distance of twelve miles; and if its extent seems out of proportion to its population, which in 1909 was 138,000 , we must not 
forget that Batavia, besides the old city, contains the new city with its wealthy quarter of Weltevreden (Well Content), and also Tandjong Priok, which is the shipping quarter of Batavia. To be logical, we ought really to include Meester Cornelis (33,990 inhabitants, of whom I,700 are Europeans), Buitenzorg (Sans-souci, 33,400 inhabitants), the seat of the Government, Tanggerang $(4,454$ inhabitants), and even Bekasi, with its bustling Chinese bazaars and charming country villas. The centre of this complex organism is old Batavia, built upon the right bank of the Tji Liwong : showing, at the entrance of the channel, the four bastions of the citadel, which is situated upon a small island. Nature has overcome these defences more easily than man; for, following upon a series of volcanic eruptions, the canals of Batavia were choked with ashes, while the alluvial deposits of the river slowly separated the city from the sea, until to-day they are parted by a distance of nearly two miles. The stagnation of the water in the canals, and the proximity of a coast-line which was always in process of formation and always half a swamp, continued to make old Batavia so unhealthy that the colonists decided to abandon their houses : those eighteenth-century red-brick gabled houses which were like a corner of Holland amidst the exotic foliage ; tourists still visit the quarter to admire them, but they are occupied now only as offices, or by Chinese or natives, whose kampongs are huddled together in the most picturesque but evil-smelling medley, amidst the old decaying houses; close to the mangroves of the shifting shore-line, a constant breeding-place of dangerous fevers.

The Dutch, in their greater wisdom, have removed their port to Tandjong Priok, some six and a quarter miles beyond the old city, and their dwelling-houses to Weltevreden, which is a mile or two south of the old Batavia, standing upon a slight eminence which preserves it from the marshy miasmata, and allows the residents occasionally to enjoy the sea-breeze.

Tandjong Priok is situated on the great bay of Batavia, which lies between Cape Untung Djawa and Krawang 
Point. The harbour is accessible to vessels of the highest tonnage. The roadstead has a length of twentyfour miles and a width of eight ; the harbour proper is at the mouth of the $\mathrm{Tji}$ Liwong. The outer harbour is enclosed between two gigantic jetties of hewn stone, 25 feet in width at the top : it is 2,000 yards wide, and the opening has a width of 136 feet. The inner basin, which is surrounded by quays for trading-vessels, has a length of I,2 IO yards, a width of 190 yards, and a depth of 25 feet.

The quay itself, which is $8 \mathrm{ft} .2 \mathrm{in}$. above low water, extends for a distance of $\mathrm{I}, \mathrm{I} 00$ yards. The harbour contains a dry dock, graving and careening slips, a coaling station, building slips; all the equipment, in short, of a modern port. A good road, a canal, and a railway unite it with Batavia. The cost of the harbour was $26 \frac{1}{2}$ million florins-about $£ 3,000,000$; and it is the site of a considerable trade in coffee, sugar, indigo, quinine, and copra, which it exports, receiving in return an enormous quantity of manufactured articles, particularly from Holland, England, and Germany.

Tandjong Priok represents the wealth and activity of Batavia. Weltevreden, the new city, is the symbol of its luxury, with its vast, sumptuous avenues, its magnificent gardens, which give the whole quarter the aspect of a wonderful park, with a sprinkling of houses whose simple, almost rustic architecture, adds yet another charm to all this natural beauty. One scarcely notices them at first on passing through the splendid avenues, so well are they concealed by the exuberant tropical vegetation.

The centre of the city is Koningsplein, an immense rectangular space twice as large as the Champ de Mars in Paris. Here towards nine o'clock each evening the Dutch ladies and a few handsome half-castes take the air ; sometimes on foot, but more often driving ; wearing their most fashionable frocks, but nearly always bareheaded; a custom by which beauty gains if European etiquette suffers. This graceful fashion, thanks to the 
influence of snobbery, shows signs of disappearing. The four sides of the Koningsplein are bordered by the wealthier private houses, standing behind groups of trees; here, too, is the huge and somewhat heavy palace of the Governor-General, and the archæological and ethnographical museum of the Society of Arts and Sciences of Batavia, which was founded in 1778 , and whose publications ${ }^{\mathbf{I}}$ are a mine of precious information concerning the East Indies.

The Koningsplein is connected by Willemslaan to the Waterlooplein, which seems small in comparison with the former, although it would still seem immense in Europe ; but it is as green and enchanting as the larger place, although somewhat unfortunately marred by a rather miserable monument in memory of Waterloo, a statue of Jan Coen, the founder of Batavia in I6rg, and an iron pyramid to the memory of the brave General Michiels : none of which can be regarded as an artistic success. The Waterlooplein is overlooked by the palace of the Colonial Office (Colonial Services) and the graceful Catholic cathedral.

The sight of the entire city, outspread in the midst of its wonderful gardens, has none of that utilitarian ugliness with which the agglomeration of second-rate buildings and an over-driven existence deface our modern European cities. In the remote background, at a respectful distance, and hidden by their enclosures of cabbage and coco-palms, are the kampongs of the natives, which are drawn like a motley girdle round stately Weltevreden, which pushes its villas in brick and wood on the one hand along the canal which runs from that quarter to old Batavia, while on the other hand the villas reach as far as the overgrown village of Meester Cornelis (33,900 inhabitants), an entertaining mixture of European bungalows, the houses of wealthy Chinese, and dirty native quarters, swarming with life and colour.

One cannot speak of Batavia without the immediate

' Bataviaasch Genootschap van Kunsten en Wetenschappen : Verhandelingen, Tijdschrift, Notulen. 
thought of Buitenzorg, which prides itself upon being the motive centre, the brain almost, of Batavia. It stands twenty miles from the capital, on a site which is infinitely more healthy and more beautiful; a leafy hill of 870 feet in height, which overlooks the valley of the Tji Liwong and the Tji Dani, while beyond it are incomparable views of Gedei and Salak, the two great volcanoes. Buitenzorg, known in Javanese as Bogor, boasts of a botanical garden unique in the world ; to speak precisely it is rather a botanical institute, as the most perfectly equipped laboratories are combined with the most wonderful collection of tropical plants that any naturalist could dream of, enclosed in a frame to delight the heart of a painter or poet. In this peculiarly moist, warm climate-for at Buitenzorg it rains every day from two to seven in the afternoon-the vegetation shows an extraordinary development and variety. More than ten thousand species of plants are here assembled: cocopalms, cabbage-palms, palms of all varieties, eucalyptus and the red jasmine, all intermingled with a grace and vigour peculiar to the place, for on this favoured soil they attain an unexampled development, particularly as to height. The Botanical Garden of Buitenzorg has evaded both the deliberate disorder of a virgin forest, in which the tangled exuberance of vegetation produces a disconcerting impression of discomfort, and the too strictly formal order of the classical botanical garden; Art has helped Nature with a loving tact, and the rarest species grow in a happy liberty, blending in the most harmonious manner with one another and with the distant background of a perfect landscape. ${ }^{x}$

A visit to the Botanical Garden of Buitenzorg is as great a pleasure to the mere traveller as to the scientist, although perhaps for different reasons; but the gardens are not the only attraction which the Europeans of Java find in

× There is an excellent Notice sur l'état actuel de l'Institut by its one-time Director, Dr. Treub, in s' Lands Plantentuin, Bulletin de l'Institut botanique de Buitenzorg, No. I. (Buitenzorg, printed at the Institute, $1898,8 \mathrm{vo}$.) 
this charming town. It is at Buitenzorg, in a palace surrounded with flowers, lawns, and groups of trees, such as might be the envy of any royal residence in Europe, that the Governor-General of the Dutch East Indies resides, the representative of the executive power in the colony. Since I774 the Governors have been used to seek a refreshing air and a little repose in this well-named hill-station-Buitenzorg, the Care-free, SansSouci; there they built a country villa, and finally appreciated the place so well that they transported thither the entire Secretariat-General; and since then the eyes of all the officials in Java have been turned towards Buitenzorg, the source of all executive orders, and also of promotion. The Europeans of the Archipelago, whether merchants or planters, learned in their turn of the reviving effects of Buitenzorg; and while the Government established a hospital there for those convalescent from beri-beri, they flocked there every year for a stay of several months, so that in spite of its entirely official character the town is full of visitors coming and going.

Puwokarta, and Krawang, the old Cravaon of the Portuguese, formerly itself the capital of a suppressed Residency of the same name (connected by rail with Meester Cornelis and Batavia, but without gaining much thereby), are the only two district capitals worth mentioning in the province of Batavia.

The Residency or province of Cheribon or Tjiribon contains some large villages and markets, but no city worthy of remark by reason either of its population or activity, excepting the capital of the same name. The city of Cheribon (23,450 inhabitants) on the Tji-Ribon, or river of crayfish, to which it owes its name, is a picturesque old town, in which the European, Chinese, Arab, and Javanese quarters strike each its characteristic note. It might, on this muddy, indefinite sea-coast, have become a port of some importance, had not the coral reefs rendered its roadstead unsafe. It is, however, a place of pilgrimage for many fervent Arab, 
Malay, or Javanese Mahomedans, who go thither to venerate the tomb of the Susuhunan Gunang Djati, the founder of Cheribon, and one of the great propagandists of Islam in Java. His remote descendants live not far from this holy but somewhat dilapidated object, in a kraton (palace) full of a rather tawdry luxury, subsisting on a very comfortable pension paid them by the Dutch Government.

The Residency of the Preangers, which is to the south of Bantam, Batavia, and Cheribon, and with them constitutes the eastern division of Java, surpasses them all in extent, population, and natural beauty. It contains no less than $8, \mathrm{I} 78$ square miles, and 2,435,500 inhabitants, of whom some 4,000 are Europeans. There are few large towns excepting Bandung, the capital, but a host of kampongs : great overgrown villages, built amid the most luxuriant vegetation, on the most incomparable sites. Enthusiastic travellers, struck by the marvellous light and the fresh green of the Javanese foliage, have called the fortunate island a terrestrial paradise. If it be so, then the Preangers should be the paradise of this paradise. Here too-a fact not to be disdained-are the finest plantations of coffee, tea, quinine, and sugarcane to be found in the East Indies. If only this province did not face the Indian Ocean, which forms the whole of its southern boundary, it is probable that the productive value of the Preangers would be doubled; but the depth of the water makes the construction of harbours or artificial roadsteads impossible.

Bandung, which since 1864 has been the capital of the province, is a very pleasant town, nestling amidst its trees, at a height of 2,300 feet above the sea. It grows, so to speak, while one watches it, but without losing any of its beauty. In $\mathrm{I} 893$ it contained only 23,800 inhabitants; to-day there are 47,470 , of whom 2,200 are Europeans.

Garut and Sukabumi, connected with Bandung by the railway, are, from the European point of view, simply sanatoria, installed in the midst of Javanese native life, 


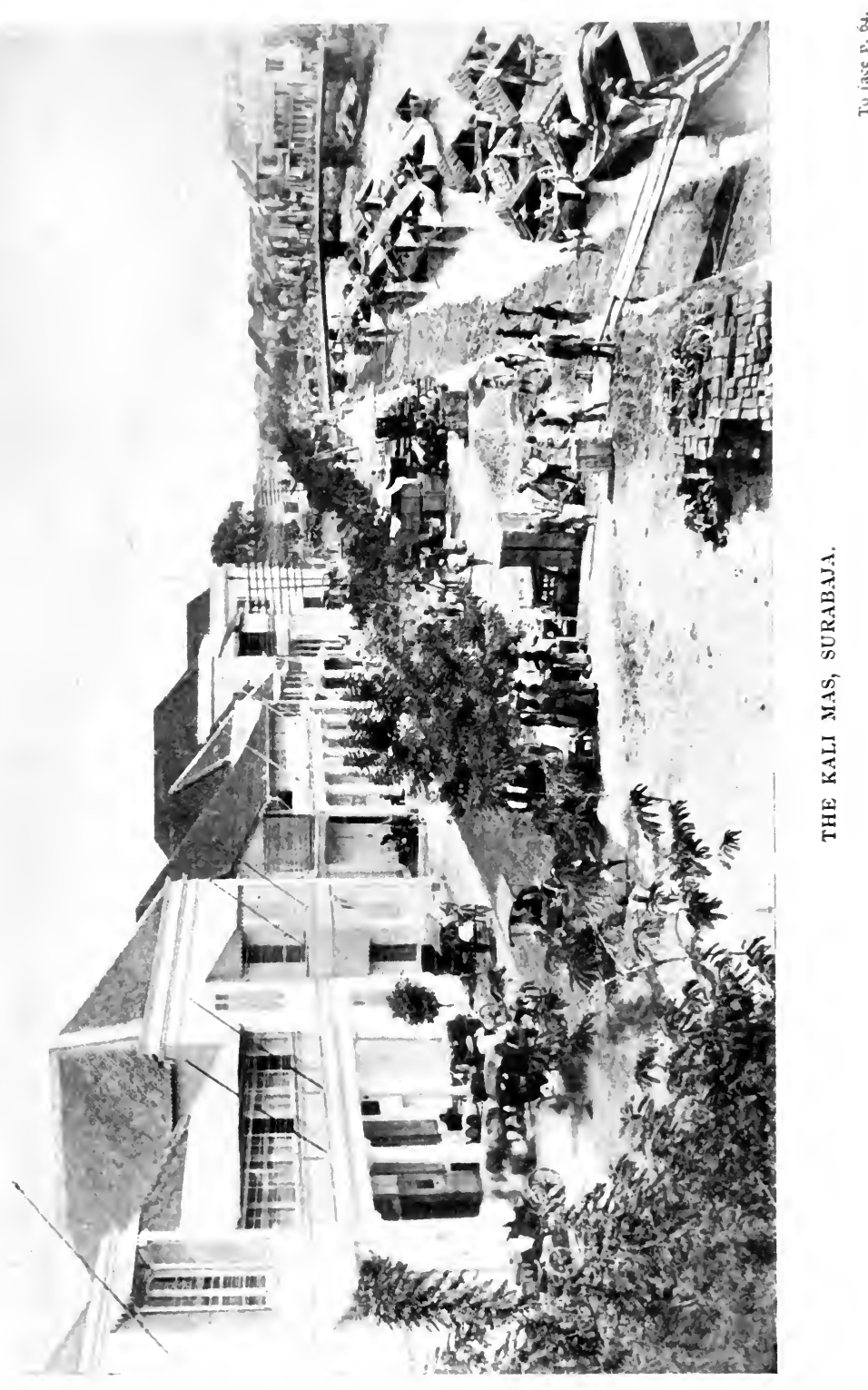



in a delightful climate. Sukabumi (Place of Delights) has over 15,000 inhabitants, but only 588 are Europeans, exclusive of the convalescents whom the State sends up year by year to the establishment built for that end. The Dutch Government has installed two other sanatoria in the Residency of Preanger : one at Tegal-laga, near Bandung, and one at Sindanglaja.

Formerly many East Indian officials, having retired upon their pensions, came to end their lives under the trees of Sukabumi; to-day they return more willingly to die in their native country.

Garut, at a height of 2,300 feet, more sparsely peopled than Sukabumi, is almost as attractive, by reason of its climate and its individual charm. Formerly a holy city, forbidden to Europeans, it is now more and more frequented by foreigners.

\section{II.}

Central Java comprises the Residencies of Pekalongan, Samarang, Banjumas, Kedu, Djokjakarta and Surakarta, Rembang, and Madiun. The first two Residencies are situated on the Java Sea, and absorb the commercial products of the other four on their way to the outer world.

The province of Pekalongan, despite its three small ports-Brebes, Tegal, and Pemalang (20,920 inhabitants) - contains only one important town: the capital, Pekalongan (4I,720 inhabitants), which is built upon both banks of the River Pekalongan. The houses of the European quarter are built on the left bank, along an avenue of magnificent canary-trees and tamarinds. This quarter, which is well away from the native and Chinese quarters, boasts of the inevitable "plein," place, or promenade, with its administrative offices, the Residency, and the Protestant Church; and not far off is the customary aloun-aloun, $\mathbf{I}$ with the mosque and the

x The aloun-aloun is the public place, the centre of official native life, just as the "plein" is the centre of European life. It 
Regent's palace. The Chinese, even more than the Arabs, hold in their hands the greater part of the retail trade of the neighbourhood, and indeed of the whole coast; at Tegal they even profess to have been established since the tenth century.

The Residency of Samarang far surpasses that of Pekalongan by the number of its towns and their activity and density of population. Kudus, Salatiga, Kendal, Japara, and Pati all contain from ten thousand to thirty thousand inhabitants. Samarang, the capital ( 96,660 inhabitants, of whom 5, 126 are Europeans), is one of the three great commercial centres of the island, ranking with Batavia and Surabaja. The city has developed rapidly since the proclamation of free labour, and has become one of the great depôts of the products of the country : coffee, tobacco, indigo, sugar, and rice.

Another cause of prosperity has been the construction of railways running from the coast to the Principalities, or Vorstenlanden, of Djokjakarta and Surakarta, which has enabled Samarang to attract nearly all the trade of Central Java. The improvement of the port has made it more accessible, although it does not make up for the absence of a safe and capacious roadstead, which would be worth a large fortune to the city. The city itself is built on the two banks and at the mouth of the insignificant river of the same name; its only interest lies in the continual movements of the lighters towards the ships, and the magnificent sunshine which never fails the East Indian landscape. The old city, built, by a natural and pathetic fallacy, in the Dutch manner-its two-story houses crowded together in the narrow streets, without the ventilation of large gardens-is so insupportably hot that all who have been able to desert it have done so; it is used now only for stores and warehouses, and, in the more habitable quarters, for barracks and orphan asylums. The Europeans have taken refuge on the road

is almost always a great grassy square or oblong, planted with enormous banyans, which trees are greatly venerated by the Hindus and the Javanese. 
to Bondjong and Pontjol (two quarters of the new city), which stand a little higher than the surrounding plain. There they have built their white villas, shaded by tall trees. A magnificent avenue of tamarind-trees connects Bondjong with the aloun-aloun, the central public square of every native town, where the Government offices, the Residency, the town hall, indeed all the official buildings, are grouped about its green expanse. More interesting still to the traveller is the Chinese quarter, which is built upon the Samarang River, a little way above the city, and is almost as picturesque as it is dirty ; or the houses of the Javanese kampong, scattered among the coco-palms, or along the roads, or on the banks of the canal, according to the occupations of the inhabitants. At a quarter of an hour's distance, to the south of Samarang, and on the first slopes of the mountain, is the suburb of Tjandi, which is rich in the ruins of Hindu temples, to which the natives still bring their humble offerings of flowers and fruits. Not far from here the Europeans are beginning to build, as it is cooler than in Samarang itself. Well provided with roads, canals, railways, steam tramways, and steamship lines, active and enterprising, Samarang is wealthy rather than attractive.

Its opulent aspect is a contrast to the semi-poverty of its neighbour Demak, formerly the capital of a powerful State, and not long ago the capital of a Residency which is now simply a district of the Residency of Samarang. Situated in a cool and luxuriant valley, Demak has to-day only 5,250 inhabitants; despite the line of steam trams which connects it with Samarang and Joana, $\mathbf{x}$ it vegetates miserably. Yet here, in the fifteenth or sixteenth century, was founded a dynasty of Musulman princes, fervent propagandists of Islam, whose turbulent proselytism made them for a time the moral rulers of Central Java. One of them-a very holy but also a very ambitious man-Raden Patah, built, it

* Or rather Djoewana. Joana is an English spelling, often used by preference, as in the expression Samarang-Foana-Stoomtram = Samarang and Joana Steam Tramway. 
is said, the city mosque, which is celebrated throughout Java, and was completed in 1468 . In 1845 it had to be rebuilt; but care was taken to preserve in the new structure some sculptured columns, venerable relics of the old. From Demak issued, in the latter half of the fifteenth century, the religious and political movement which banded together the petty Musulman princes of the north coast of Java for the purpose of annihilating the great Indo-Javanese kingdom of Madjapahit. At their head, justly enough, was Raden Patah, son or grandson, so it was said, of the Sultan of Madjapahit, who wished at one blow to avenge an injury done to his mother and to secure the triumph of Islam. $\mathrm{He}$ succeeded: the Arab supplanted the Hindu civilisation throughout the island; but two centuries later the Dutch laid hands upon the warlike petty princes and their territory. Further decimated in 1848 by a terrible famine, Demak lingers rather than lives.

Kudus, better advised, has preserved, with a religious respect, the minaret of its ancient mosque, and the famous tomb of its eminently holy founder, the Pangeran Kudus. ${ }^{x}$ But it has not allowed its material interests to suffer; it has left the ancient city to the memories of its historic past, and has built beside it a new city, which is completely modern, although purely in the native style. The wooden dwellings are neater, cleaner, and more graceful than in any other part of the island; their façades, delicately carved, are famous through all Java. It is to this charming town that the inhabitants of Kudus, energetic brokers and carriers of produce, return after scouring the country from one end to another, sometimes for years together, in order to take their well-earned rest and enjoy the fruits of their labour.

Salatiga contains an almost equally industrious population, and enjoys a delightful climate, which has led to the erection of a sanatorium.

Ambarawa, in a steep, marshy valley of the volcano × Pangeran $=$ Lord or Prince. 


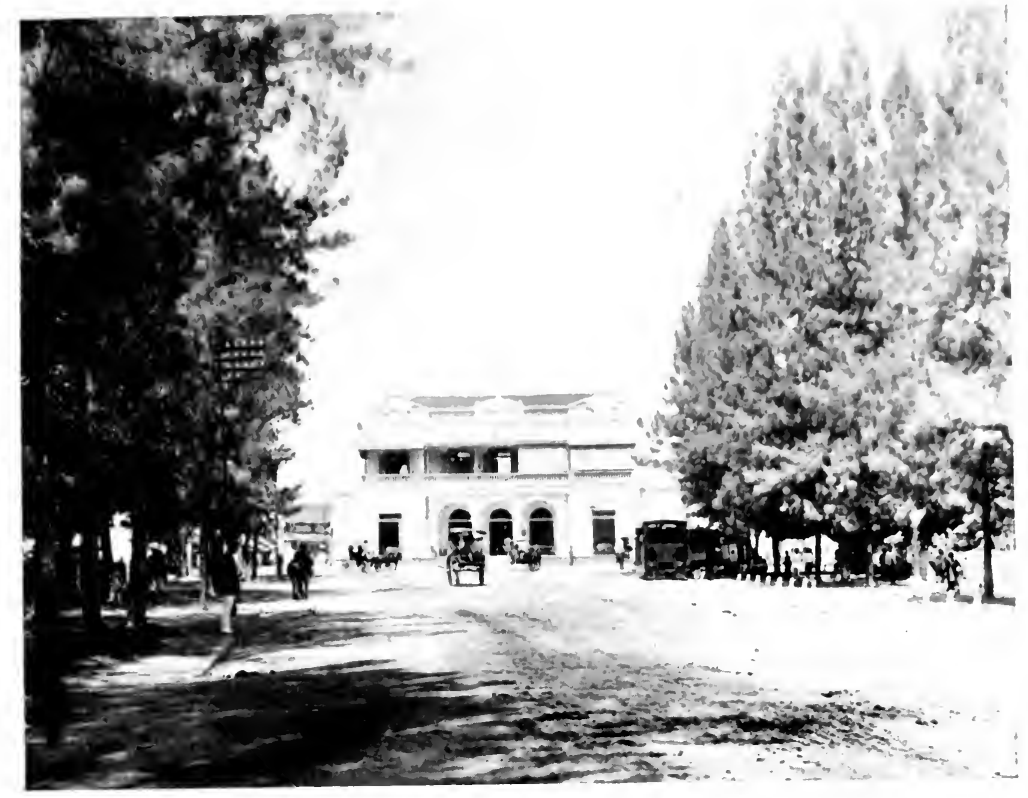

GRIMM'S RESTACRANT, SURABAJA.

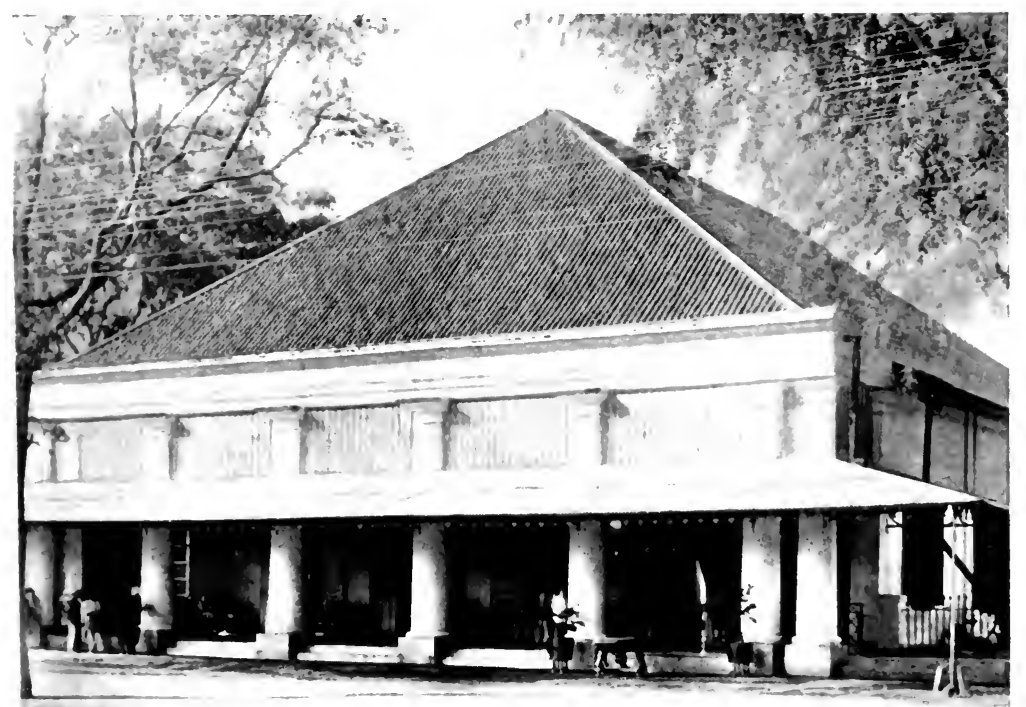



Merbabu, is merely a fortress, originally intended to bridle the Sultans of Surakarta and Djokjakarta, and to prevent their making raids upon the Dutch possessions on the coast. It is, above all, an example of Dutch tenacity, its utility to-day being practically nil. Commenced about 1837 , it was built of human lives, for the builders had to fight three enemies: the marsh fever; the treacherous, muddy water, which would suddenly sweep away work and workers; and finally an eruption of Merbabu, which in July, 1867, when the work was apparently completed, cracked or destroyed the whole structure. Worse still: at the end of numerous periods of forced labour, to which the unhappy inhabitants of the country had been compelled, a terrible famine broke out, as the peasants had been unable to sow and to cultivate their rice-fields. Ambarawa, created by the will of the metropolis, according to the plans of the metropolis, in obedience also to its remote brutality, was one of the last great moral mistakes of the Dutch. It would always have been quite insufficient to stand against good artillery; and although it instilled a salutary terror in the hearts of the neighbouring populations, it also left them with a dangerous sense of unforgiving resentment.

The Residency of Banjumas, to the south of that of Samarang, is important on account of its situation rather than its economic importance. It is of value in that it helps to divide the formerly formidable Principalities from the turbulent Residency of the Preangers. Banjumas, its capital, in spite of its rather high-flown name (Golden Water), is a second-rate village of 5,795 inhabitants. The principal towns of the district are: Purwokerto (13,768 inhabitants), Probolinggo (г3,237), and Bandjernagara $(5,875)$, which are scarcely more lively.

The only exception is Tjilatjap, the great commercial and military port of the south. Tjilatjap is built in modern fashion, and is laid out in a very symmetrical manner, with huge, shady avenues-almost too huge, in fact, for the city scarcely seems likely to realise the 
hopes that were conceived of it, and this for two reasons : both the climate and the nature of the soil, which are closely connected, are unfavourable. It is built upon a dried-up swamp, beside a muddy coast which bristles with coral; it is extremely unhealthy during the western monsoon, being then invaded by the poisonous exhalations of the shore; the south-western monsoon, which brings the sea-breeze, renders it somewhat more healthy.

The malaria endemic in Tjilatjap has the peculiarity that its worst effects are felt only after leaving the place; it undermines the constitution of the resident, but he is hardly aware of his condition. It is, nevertheless, so deadly a complaint that Tjilatjap has been called "the European cemetery," and the Government has been forced to withdraw its garrisons.

The roadstead, which is very extensive, and capable of floating large vessels at low tide, is protected by a natural breakwater of coral; but the entrance is difficult, bristling with reefs, and is gradually becoming obstructed by the alluvium of the Tjilatjap, the estuary of which it faces. The muddy waters of the river are already slowly filling the great Gulf of Segara Anakan, or the Sea of the Children, and their deposits of slime and ooze have connected the island of Kambangan with the mainland. It is to be feared that in the end they will close the bar rather than increase its efficiency. Although at the very gates of the fertile province of the Preangers, and by nature fitted to be the port and market for the produce of the south-east of Java and a portion of the centre, Tjilatjap will never rival in growth the ports of Samarang and Surabaja, because it is upon the Indian Ocean, which has no commercial future as regards the Archipelago.

III.

The Residency of Kedu, bounded by Samarang on the north and the Principality of Djokjakarta on the east, retains the charm of a great past and an indestructible natural beauty. Situated in the region of the great 
volcanoes, backed by the majestic slopes of Sumbing, Sindoro, Merbabu, and Merapi, which enclose it by a crescent-shaped range, it is full of fertile valleys of enchanting beauty. Its capital, Magelang $(28,240$ inhabitants, comprising 723 Europeans and 2,746 Chinese), is in the midst of a magnificently fruitful plain, which has been fertilised by the debris of the volcanoes. With its abundance of clear, running water, and the brilliant fresh foliage of its rice-fields, its plantations of coffee and sugar-cane, it gives the impression of a Garden of Eden, and the delightful climate adds to the illusion.

Purworedjo (14,205 inhabitants), the capital of the sometime province of Bagelen, has almost the charm of Magelang, which is now its administrative superior. It is easy to understand that where life is so easy and so pleasant the natives give but little thought to other things, and care little about enriching themselves, and still less about enriching their masters by the unceasing cultivation of coffee, sugar-cane, and tea, or by joylessly labouring in the few manufactories or workshops which have been erected by the uncontrollable energy of Europe. Nevertheless, this Garden of Eden has known a superior standard of life, has been the seat of a higher and more stable civilisation than the neighbouring provinces, and retains the vestiges of an art that strikes us even to-day with astonishment and admiration.

Nine miles from Magelang is the Tjandi Boro-Budur, the Temple of the Thousand Buddhas-a gigantic stupa, ${ }^{\mathbf{x}}$ built not upon a hill but around it, the hill forming the core of the stupa, and being enclosed by a series of sculptured terraces or balconies, which end in a central terrace surmounted by a gigantic dagoba. ${ }^{2}$ There are no less than nine stories or stages of galleries built around the huge core of earth; the six lower galleries are square, with re-entrant angles, and the three upper

× Sanscrit. A sacred tumulus to indicate the site of some episode in the life of Buddha, or enclosing some of his ashes or relics.

- A variety or modification of the stupa. 
galleries are circular, and are surmounted by seventytwo open dagobas containing statues of Buddha. From the first gallery upwards the sustaining wall is covered with bas-reliefs illustrating various episodes in the life of Buddha ; gargoyles, as fantastic as any on our Gothic cathedrals, decorate each angle; delicate schemes of decoration-flowers, birds, animals-break the monotony of the gutters and run along the cornices. The summit of the monument, consisting of the three circular terraces and the seventy-two dagobas, is surmounted by the central dagoba, which also contains a statue of Buddha, and in which some bronze statuettes and coins were discovered many years ago. Each side of the structure measures no less than I77 yards (53I feet) in length at the base, and the carvings, if set end to end, would measure $3,85^{\circ}$ yards, or considerably over two miles, in length. Built presumably in the eighth or ninth century, by Javanese working under the inspiration of Hindu architects, it must once, according to the legend, have sheltered in its terminal cupola a pinch of the revered ashes of the Buddha. It is built without the aid of lime or mortar, the stones being jointed by means of tenons and mortices and dovetails which bind them solidly together. The material is volcanic lava, whose greyish tint enhances the imposing and melancholy effect of this enormous and complex structure-a melancholy hardly enlivened by the most fantastic virtuosity of the chisel. It stands facing Merapi, in a wide plain of slender coco-palms, the horizon closed by a scattered range of extinct volcanoes.

Only the ruins of Angkor Wat, in French Indo-China, can rival Boro Budur in grandeur. Hindu by inspiration, like the latter, they surpass it in point of size, and are perhaps superior in grace, justness of proportion, and delicacy of ornamentation.

The Dutch Government, at the repeated instance of such scholars as the late Dr. J. L. A. Brandes, and of the archæologists, amongst whom we must mention Dr. I. Groneman, the founder of the Archæological 


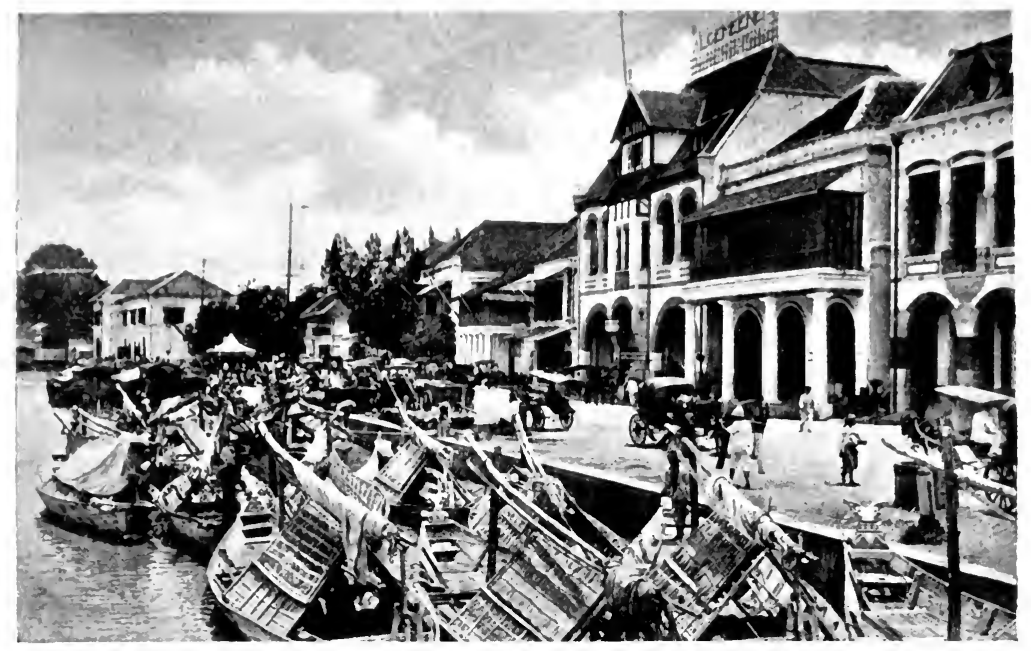

NATIVE BOATS, WILLEMSKERKE, SURABAJA.

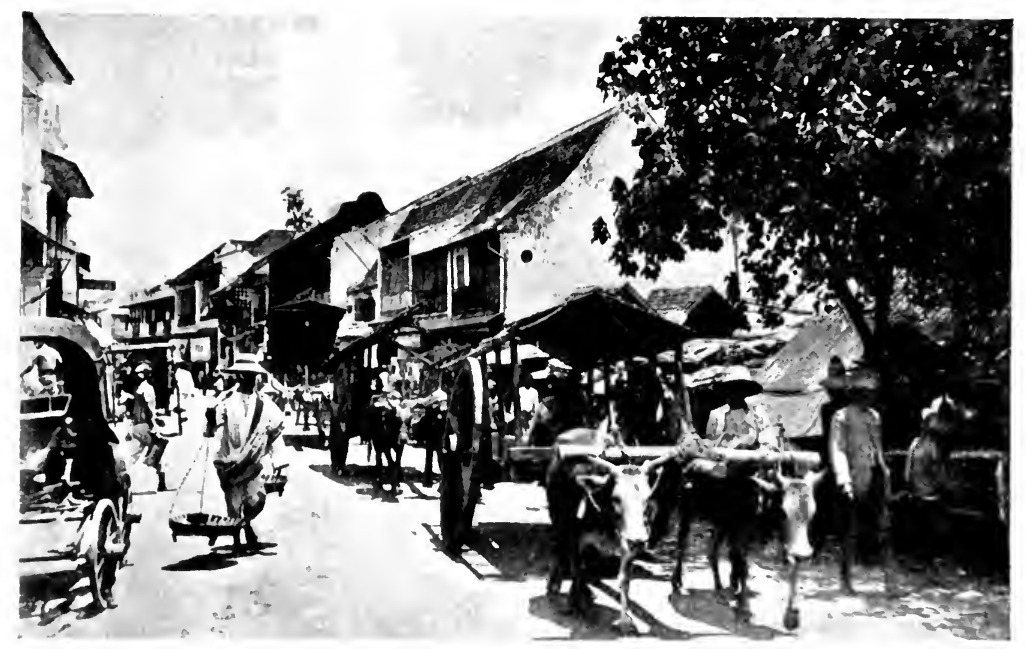

CHINESE KAMPONG, SURABAJA. 

Society of Djokjakarta, ${ }^{\mathbf{x}}$ who has done so much to draw attention to the Hindo-Javanese antiquities of the region, has at last begun to concern itself in the fate of the ruins.

The high officials and native princes who used without scruple to carry off statues and bas-reliefs for the decoration of their gardens or palaces, and the peasants who, with an unconscious vandalism which was at least more comprehensible, used to carry off the stones to be used for the most vulgar or trivial purposes, have been requested to stop their depredations. The work of consolidation has been put in hand, and a quite adequate pasan-grahan ${ }^{2}$ has been constructed at the foot of the monument, so that not archæologists and artists only, but tourists from all parts of the world, to whom India proper is to-day a little commonplace, are now able to pay their respects to the Temple of the Thousand Buddhas without heroic efforts.

One may search the western portion of Java for the vestiges of a monument that shall even distantly remind one of Boro Budur. Here dwelt formerly, and here is to-day, the centre of Javanese civilisation. Sixteen

- Archcoologische Vereeniging le Djokjakarta. Dr. Groneman has published a guide to the ruins of Boro Budur under the title of De Tjandi Baraboedoer op Midden-Fava (Samarang, 1902, large 8vo) and many monographs on the ruins of Java.

- Pasangrahan, or better, pasanggrahan, a Javanese word signify. ing " hostelry." Analogous to the dahk bungalow of India, and the sala of Indo-China, but better equipped than the latter, the pasang. grahan is a kind of inn or hotel for the use of officials on circuit, but which extends its hospitality to travellers as well. It is established at the cost of the Dutch Government, and kept up by a village headman (tjamat) or a European soldier retired from the army of the Indies. The large pasangrahans, in addition to several chambers, provide provisions which are placed at the disposal of the traveller, according to an established tariff. Others provide primitive beds for the night, and the means of preparing the traveller's own provisions; or, if he needs no more, the eggs and rice procured in the village. The tjamat also procures horses, for the saddle or for draught, and also guides and coolies, all according to an official tariff. 
miles from Boro Budur, in the princely capital of Djokjakarta, and to an even greater degree in Surakarta, arose the great empire of Mataram, of which the whole race preserves a glorious and reverent memory.

IV.

The Vorstenlanden, or Principalities, bounded to the north by the Residency of Samarang, to the east by that of Madiun, to the west by Kedu, and to the south by the Indian Ocean, constitute the masterpiece of the Dutch colonial policy, and a striking proof of the skilful eclecticism with which the Dutch admit any form of government, provided they retain the reality of power.

The Vorstenlanden, or "Princely Lands," represent only one-fifteenth of the area of Java; they are nominally independent, and are ruled by two princes: the Susuhunan of Surakarta and the Sultan of Djokjakarta.

Until the last century they were entirely in the hands of the Susuhunan, who, being threatened by a revolt of the Chinese installed in his empire, called in the Dutch to assist him. They came promptly, helped to crush the Chinese, were handsomely paid, and remained so high in the esteem of the Emperor Hamangku that he submitted to their arbitration in his conflict with one of his brothers who was desirous of usurping his crown.

The Dutch, who perhaps were not wholly innocent of complicity with the pretender, pronounced a verdict of a very satisfactory nature, especially in view of their future intentions. The Empire was divided into two States: one, which comprised about two-thirds of the territory, remained under the rule of the Susuhunan, Surakarta being the capital ; the other, with the title of Sultan and the capital of Djokjakarta, fell to the lot of his uncle. In principle the Sultan remained the vassal of the Susuhunan; every year he rendered homage, with imposing ceremony, at Ngawen near Djokjakarta, removing his sandals and kneeling before his overlord.

It was so much in the interests of the Dutch to cause 
division between the two princes, that they could not allow this ceremony to be celebrated indefinitely; for the Javanese assembled in great numbers, and it afforded an opportunity for conspiracy or alliance. It was not difficult to persuade the Sultan that it was humiliating to be obliged to admit himself the inferior of the Susuhunan. One year, accordingly, when the time for the interview came round, the Sultan presented himself at Ngawen wearing a Dutch uniform. In virtue of a principle-as stringent as the principle of homage-which in Java forbids the kneeling posture to whosoever has the honour of bearing the insignia of European military rank-the Sultan remained seated before the Susuhunan, who left full of rage and confusion.

The two princes were at variance for a time, but each considered himself independent of the other, which was what the Dutch had desired. The latter adopted a still better means of paralysing the enmity which both the Sultan and the Susuhunan bore them; both at Surakarta and at Djokjakarta a prince is installed in the court of the sovereign; both are vassals, yet independent; they are entertained at the expense of the sovereign; but, apart from the formula of a vague homage, and their enforced presence at certain court ceremonies, they are as free in their wide domains as are their pretended masters. Their kratons, $\mathbf{x}$ or palaces, stand beside those of the sovereigns; each has, even in a greater degree than the latter, the right to maintain a private army on the European model, though this is, of course, under the control of the Dutch Government. These two princes, who in Surakarta bear the titles of Pangeran Adipati Mangku Negoro, and at Djokjakarta those of Pangeran Adipati Paku Alam, owe their power to Holland, and hitherto have been absolutely loyal and full of feudal feeling.

As a matter of fact all four, the Susuhunan included, although he is traditionally by far the most powerful of all, are in the hands of the Dutch Government, despite ${ }^{2}$ Kraton, or karaton, dwelling of a ratu, or prince. 
their sumptuous appearance of independence. At Surakarta, as at Djokjakarta, the magnificent palace of the real master, the Resident, stands facing the royal kraton; and a small fort, armed with artillery, situated not far away, stands as a reminder of the Resident's actual power. None of the four princes can ascend the throne without the consent of the Resident, who often appoints him according to the choice of his predecessor, always respecting as far as possible the national traditions and susceptibilities. The Resident, installed in the kraton, governs openly during the interregnum, which lasts from the death of one sovereign until the appointment of his successor. He may refuse any candidate whom he believes would make a bad ruler, and replace him by another chosen by himself ; and it is he who appoints and pays the Prime Minister, or patih, who must every morning give him an exact account of all that goes on in the kraton, must be loyal to him even more than to the sovereign-must, at need, act against the latter ; it is the Resident also who appoints all civil officials and officers, so that the army, the police, and the law are under his hand; and he alone may strike money. The Susuhunan and the Sultan retain the right of appointing the administrators of their domains and certain other employés. In all things they must take the advice of their "elder brother," the Resident, who in virtue of this title is regarded as their senior; all of whose "counsels" must be heard with deference, even should these phantom sovereigns conceive the inadmissible idea of neglecting to carry them out. Where the Resident and the Susuhunan appear together before the people, they are seated upon the same daï, upon similar thrones, the Resident holding the place of honour on the right.

The Susuhunan, like the three other princes, may not receive a visit or a letter from the outer world without the permission of the Resident; he may not leave his palace to go the least distance, even to take the air, without the same permission ; even in the most inaccessible quarter of the kraton he is under the "protection," 
and more especially the surveillance, of a handful of white soldiers; and the monopoly of all the most valuable products of his State-coffee, teak, salt, the produce of his mines, and the trade in the nest of the sea-swallow -have been ceded to the Dutch Government; he is held by treaties, by his surroundings, and by that unanswerable rival, the purse.

In return, the princes receive from the Dutch Government handsome pensions, in proportion to their political importance; in the case of the Susuhunan this pension amounts to some $£ 70,000$ per annum. The Government maintains at their courts the over-scrupulous etiquette, the pompous titles, and the traditional ceremonies to which the whole Javanese people are so greatly attached; it also maintains the payongs (parasols), which are the emblems of their high rank. It is true that in all interviews with the princes the Resident is himself provided with a payong as large as that of the Susuhunan. $\mathrm{He}$ treats them, or should treat them outwardly in all things with the greatest deference. The nations are apparently subject only to their own laws, their own judges, and their own sovereign; and although they are conscious, over all, of the hand of the foreigner, they have been accustomed for centuries to a passive submission to their despots, so that their national susceptibilities are safeguarded, and they remain obedient. The princes having around them all the outworn pageantry of their courts, full harems, and abundance of money to expend on luxuries and puerile caprices, are also well satisfied; moreover, they are chosen and educated with a view to ensuring their content.

Thanks to the ability and diplomacy displayed, the "Princely Lands," which still remain, for every Javanese, the real heart of Java, I have given the Dutch no anxiety

$\therefore$ "Here the heart of Java used to beat ; and nowhere have Javanese life, costume, and tradition persisted as in these States, where the ancient Hindu architects built their splendid temples, which even to-day are objects of respect and admiration to all who have a feeling for art and beauty. Here we still find the flower of the 
since the great Javanese war (1825-1830), and are as subject to Dutch authority as is the rest of the island.

The Principality of Surakarta, consisting of the plain watered by the Solo and the Kali $x$ Denking and the Kali Pepei, its tributaries, lies between the volcanoes Merapi and Lawu, which bound it to east and west; it has a surface of 2,393 square miles, or rather more than a fifth of that of Holland. The total population is $\mathrm{I}, 5^{12,773}$ inhabitants.

The soil is fertile, and covered with plantations of coffee, sugar, quinine, pepper, kapok or native cotton, vanilla, \&c. Surakarta, which the Javanese call Solo, and which was formerly known as Kartasura (the city built by heroes) is scattered over a site some fourteen miles in circumference, and consists of a host of wretchedlooking little houses; but they are lost in a perfect forest of coco-palms, fig-trees, tamarinds, and so forth, from which emerges only the mass of the kratons, the Dutch fortress, and the Resident's palace. Vast avenues of waringins, symbols of eternity and power, unite these various buildings.

Surakarta contains 109,808 inhabitants, of whom $\mathrm{I}, 5 \mathrm{I} 2$ are Europeans and 6,532 Chinese. The Europeans include a Resident and an Assistant Resident; the former being entrusted with all important political affairs, while the latter is more especially qualified to administrate the monopolies granted to Holland, and to watch over the rights of Europeans and Chinese.

The European houses and the Protestant church are gathered around the magnificent Residency, in the shadow of the fortress constructed in I799 and restored at the time of the war. All the Europeans in the principality-planters, officers, or officials-are under the obligation of presenting themselves at the Residency once a year, in order to celebrate the Dutch national

Javanese nobility; and here both language and religion have most faithfully preserved their original form." (H. H. van Kol, Soerakarta, Indische Gids., I904, ii.)

${ }^{\prime} \mathrm{Kali}$, in Malay and in Javanese, means river. 


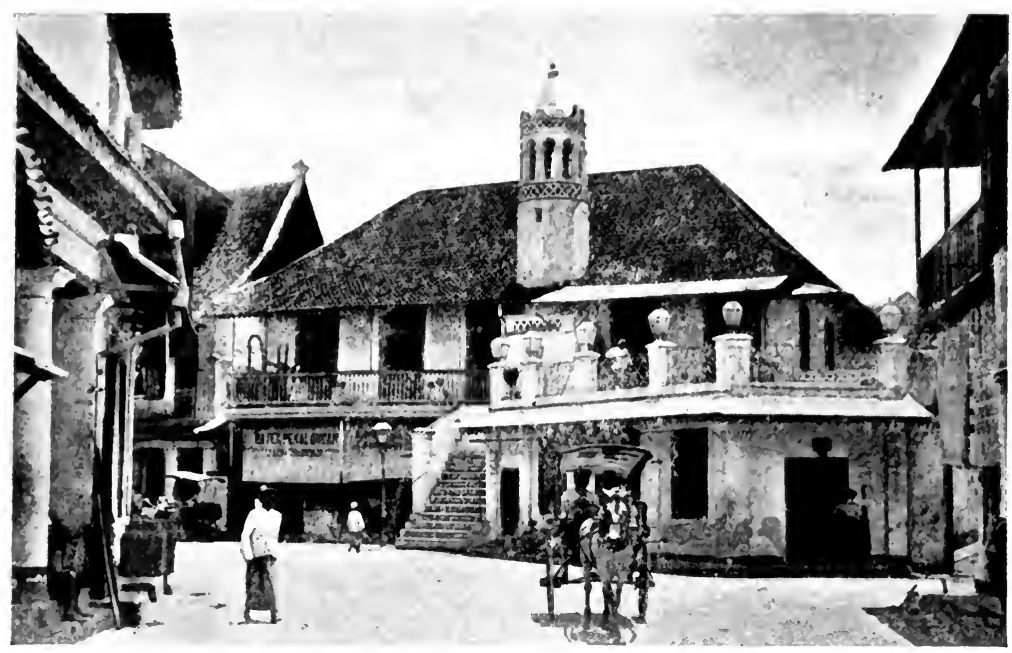

ARAB MOSQUE, SURABAJA.

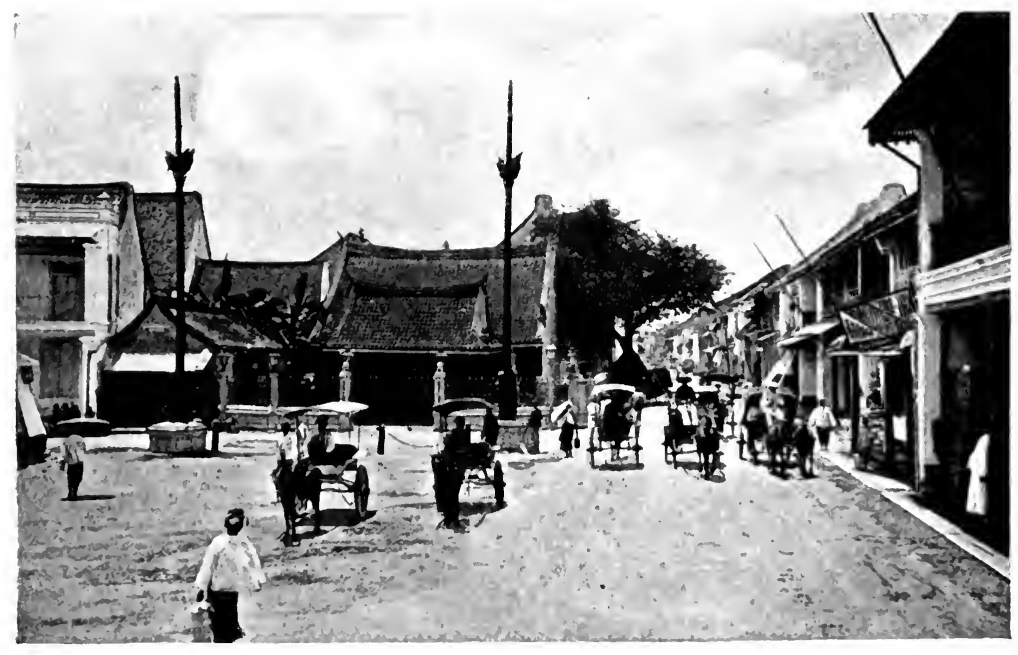

CHINESF THMPIE, SERHBAA. 

festival, under the penalty of a fine of about one hundred florins; for the Dutch Government is anxious to show the natives, who once succeeded in proving their capacity as an enemy to be reckoned with, the perfect discipline and cohesion of its white subjects.

The Chinese quarter of the city is the busiest commercially ; it is full of bazaars, and all kinds of industries peculiar to Oriental life. The kampongs of Javanese of the lower classes are scattered here and there along narrow paths which open on the great avenues, or even along the sides of the avenues themselves; their houses are of wood and bamboo, thatched with palm-leaves. They ply various trades, but especially those of the goldsmith and the saddler, their saddlery being especially famous. The women weave and batik sarongs, which have a great reputation throughout the island, on account of their original designs and their tasteful colours.

There are two kratons of unequal importance in Surakarta: that of the independent prince, the Pangeran Adipati Mangku-Negoro, is perhaps the more luxurious because better ordered, and arranged more in the European manner. It is also rendered more conspicuous by the presence of a little army of eight or nine hundred men, whom the prince has the right to maintain within the city. But the kraton of the Susuhunan is sacred in the eyes of the Javanese. It is separated from the Residency only by the great alounaloun; and in its vast enclosure, the walls of which are pierced by four gates, above each of which rises a high watch-tower, it contains, like all the palaces of Asiatic rulers, a royal city in the heart of the capital. The kraton of Surakarta, which consists of a series of courtyards, lanes, and promenades, flanked by numerous buildings, is a perfect hive of people, containing no less than ten thousand inhabitants, the majority of whom are women, since not only has the Susuhunan his harem in his private apartments, but he may never be served or

r The batik process is described farther on. 
approached except by women. Everything that the sovereign can require, every necessity of life and of pleasure, is assembled within the kraton, and the spiritual element is represented by a great mosque with a gilded cupola, and the kauman, or priest's quarters, near which are the buildings reserved for the personal use of the Susuhunan, who in many parts of Java is regarded as the representative of God, and is practically worshipped in that capacity. The officers of the court have their special quarter in the kraton, as have several bodies of craftsmen : workers in gold and silver, carvers of wood, makers of furniture, masons, armourers, saddlers, and the makers of marionettes employed in the shadow theatre, or wayang, or of musical instruments for the gamelan, or the prince's orchestra.

The portion of the kraton inhabited by the Susuhunan is situated at the back of the inner court, which is overlooked by a tall minaret of four stories. As in all palaces of the Far East, one enters first the hall of audience, the pringitan, an immense chamber open on three sides, and on the fourth communicating with the royal apartments. The ceilings, the sculptured woodwork, and the slender columns are decorated or incrusted with rare woods or precious materials, which vary with the wealth of the sovereign; the effect at Surakarta being both sumptuous and graceful. A covered canopied throne is placed at the back of the apartment. Here, on the birthday of the Susuhunan, or on that of the Queen of Holland, or on the date of certain religious solemnities, are received ambassadors, distinguished strangers, and the Resident himself. These official receptions, to which no natives are admitted but those of high rank, who kneel in a posture of adoration before their sovereign, who in their eyes is clothed in a double sanctity, both temporal and spiritual, are not held more often than five or six times a year. The Susuhunan shows himself to his subjects even less frequently: seldom more than four times a year. On these occasions he is always accompanied by his "elder brother," the Resident, who wields the actual 
power. Decked out like an idol in wonderful jewels, and followed by a many-coloured retinue of women, warriors, and amazons, he proceeds with pomp to the siti-inggil, a kind of platform erected near the entry, but within the walls of the kraton, surmounted by a kind of throne, on which the two powers take their seats beneath a canopy. Without the gates, the people massed in the aloun-aloun prostrate themselves in worship, their faces in the dust, happy in the sight of what for them is the supreme incarnation of all the powers of the earth. The Susuhunan receives also the homage of his nobles, who drag themselves on hands and knees to the foot of the throne. Then the entire staff of the kraton passes before him in review, including his guard of honour; and then a distribution of food is made among the crowd, the food being carried in enormous baskets, the least of them, like all that concerns his sacred person, being sheltered by a huge payong, or parasol, of gold. Finally sweetmeats and betel-nut are offered to his entourage; he then returns, with no less solemnity, to bury himself in his harem, amidst his three thousand wives, to waste, in a grotesque luxury, his strength, his intelligence, his will, and the $£ 200,000$ of revenue which are still his to spend each year.

Close to the royal kraton and that of the sovereign's quasi-rival, the Mangku Negoro, the princes of the royal family and the high dignitaries of the court have built their dalems, or palaces, similar, though smaller in size and less luxurious, to the kraton of the Susuhunan. The prime minister or Grand Vizir, often a near kinsman of the sovereign, but a faithful ally of the Dutch, who alone appoint him to this important post of supervision, endeavours, like the Mangku Negoro, to interpret his more progressive ideas by the more practical, modern, and European arrangement of his dwelling.

Klaten (8,209 inhabitants), Bojolali $(6,125)$, and Sragen $(7,963)$, are the only large villages which have as yet sprung up in the Principality of Surakarta. From the historian's point of view, their glory is 
departed; yet to-day they are waking to a new life under the stimulus of their economic wealth. Klaten in particular is becoming the centre of a renascence of the Javanese people, under the impulse communicated by an élite which has been created by European education, and which desires the improvement of the race, a desire devoid of any hostility towards the Dutch Government; its aim a more intelligent, just, and appropriate employment of the intelligence and the soil of Java.

The second Principality, the Sultanate of Djokjakarta, is only thirty-six miles from Surakarta, with which it is connected by a railway. Situated in a plain at the foot of Merapi, Djokjakarta, which contains 79,567 inhabitants, of whom 1,477 are Europeans and 5,266 Chinese, and covers a space some three and three-quarter miles long by two and a half miles wide, is unhappily at the mercy of the neighbouring volcano; whenever the latter enters upon a term of repose there are terrible earthquakes, one of which, in I867, destroyed the entire city and killed many of the inhabitants. Djokjakarta is built on the same plan as that of its sister city Surakarta, but is ruled by a Sultan instead of a Susuhanan, which implies a certain degree of inferiority. The Residency, which is extremely luxurious, is built in a semiEuropean, semi-Asiatic style; it is protected by a fortress, in which five hundred European soldiers watch events; the European dwellings, which in general are as comfortable as they are ornamental, are scattered about the neighbourhood; the Chinese kampong contains the bazaars and workshops of cabinet-makers of renowned skill; while the natives live in little houses among the palms, beside the majestic avenues of waringins. The kraton of the independent prince, the Paku Alam, is smaller than that of the Sultan, which is situated at one end of the aloun-aloun, the Residency being at the other end. The royal kraton, which is as large and as ineffectually fortified as that of the Susuhunan, contains the same labyrinth of lanes, courts, and innumerable buildings; it contains a population even more 


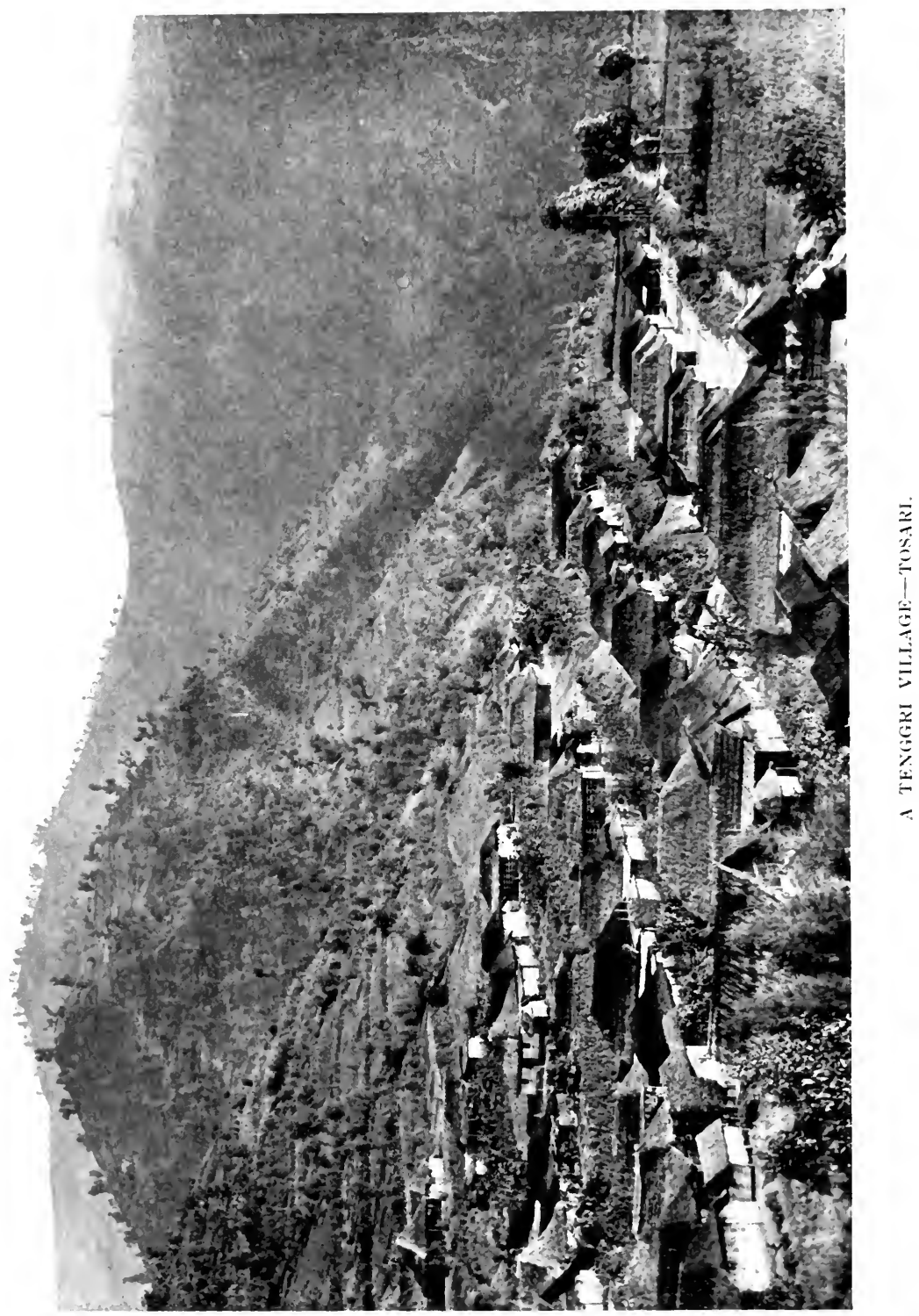



numerous, amounting to fifteen thousand souls, although the revenues of the Sultan are not as large as those of the Susuhunan. The harem, the private apartments, the little pleasure-houses built in the interior of the kraton, the wealth of carving and incrustation in the hall of audience, and the pomp displayed at important ceremonies are the object of a kind of puerile emulation between the two sovereigns.

Djokjakarta has the advantage over Surakarta of possessing, on a hill not far from the city, the venerated necropolis in which sleep four hundred princes of the house of Mataram : a turbulent, courageous, and luxurious race; and it is on the Sultan's territory that the finest IndoJavanese ruins are found, excepting only those of BoroBudur.

One of these monuments, the Tjandi Mendut, or Mundut, long buried in the sand and ashes vomited by Merapi, is only one and a quarter miles from Boro-Budur, and is, like the latter, a Buddhist temple.

It is a structure of octagonal form, crowned by a cupola in the form of a hollow pyramid, over 60 feet in height. Built, like Boro-Budur, of blocks of dressed lava, Tjandi Mendut still preserves the general outlines of the original structure and contains three colossal statues of Buddha and a number of bas-reliefs, carvings, and arabesques, examples of an assured and delicate art.

The ruins of Prambanan, on the road from Djokjakarta to Surakarta, are superior to those of Tjandi Mendut in mass, in the boldness of their architecture and the beauty of certain of the carvings. These ruins are situated in a wide plain overlooked by Merapi, which had so thoroughly covered them with its ashes, which supported a dense vegetation, that they were discovered only by chance in I797; no serious attempt at excavation was undertaken until 1885. To-day there is a question of their restoration-a question which is provoking terrible controversies between architects, archæologists, and Orientalists, and a keen anxiety among artists of all professions. The restoration of Tjandi Mendut has already been attempted 
(in 1897) by the architect Van de Kamer : with a degree of success which is variously appreciated, being highly praised by some and as warmly condemned by others.

Despite their regrettable state of decay, the ruins of Prambanan still allow one to appreciate the grandiose proportions of the Tjandi Loro Djanggrang (the Temple of the Virgin-in the shape of Durga, the spouse of Shiva) - of which they are to-day the sole remains.

On a vast square terrace are erected six great sanctuaries of polygonal form, whose platforms, cornices, and porches are decorated with bas-reliefs and sculptures equal to those of Boro-Budur : the central sanctuary was consecrated to Shiva, that on the north to Vishnu, and that on the south to Brahmah, as the three statues of the gods within the sanctuaries testify to-day. The sanctuary of Shiva is flanked by lateral chapels, of which the two most curious, dedicated to Durga and Ganesha, still contain their effigies. The great central terrace which supports the six temples is surrounded by three successive series of small temples, disposed in a square formation; the number of the small temples being forty-four in the inner rank, fifty-two in the next, and sixty in the third and outermost rank. But while the large sanctuaries, more solidly built upon the central terrace, are still preserved as regards their main features, the little temples are almost without exception mere masses of sculptured stones, broken cornices, and shattered cupolas, their ruin being the work of the threefold action of Merapi, the vegetation, and the utilitarian sacrilege of natives.

The ruins of Tjandi Sewu (the Thousand Temples), which are not far away, are not, like those of Prambanan, of a plainly Brahministic and Shivaistic type. The central sanctuary used to contain a statue of Buddha, which must, it is thought, have been removed in 1806 . For the rest, it is the largest structure among all the Indo-Javanese monuments whose ruins have as yet been discovered. As far as one can judge from its lamentable state of decay, it must have consisted of 240 
small temples, disposed in four ranks about a central square containing a large central temple, of which the cupola was shattered by the earthquake caused by Merapi in 1867 , which also blocked the entrance.

To judge by their numbers, the powers of conception which they reveal, the boldness of execution, and the perfect art of their decorations, all these monuments prove that here there formerly existed a great and flourishing empire ; extremely populous, to judge by the swarms of artisans and labourers who must have been employed in the construction of these gigantic buildings ; rich and secure, since it was able without anxiety to undertake such lengthy works of peace; deeply religious and of a high degree of civilisation, since it glorified its gods in monuments whose mere remains compel the admiration of all after centuries have elapsed. $x$

\section{V.}

The Residency of Rembang is bounded on the north by the Java Sea, yet it has not a single large port which might provide it with the commercial stimulus by which its neighbours benefit-Samarang and Surabaja. The capital, Rembang, however, although some few miles from the sea, has a dry and sandy beach, which is infinitely more healthy than the beaches of most of the north-coast ports of Java. With its thirteen thousand inhabitants it is an agreeable city, which drives an active trade in head-kerchiefs and sarongs woven and batik' $d$ in the province, carefully worked mattings, and, above all, in trasi, trubuk, and krupuk, those famous condiments of prawns and pounded and fermented fish with which the natives season their rice, and which

3 Among the temples of the plain of Prambanan and besides the group of Loro Djanggrang we have yet to mention Tjandi Plaosan and Tjandi Sari, two very remarkable Buddhist temples. The beautiful specimen of Indo-Javanese architecture which housed the East Indian Section at the Exposition of 1900 was a very successful copy of Tjandi Sari. 
some of the European colonists appreciate as eagerly as the natives. The greater portion of the trade of Rembang is in the hands of a colony of Chinese, which numbers over two thousand members. Tuban, although merely a district capital, is far more active and populous than Rembang. It has, moreover, a very different history, a still-existing witness of which is its ancient palace, one of the oldest in Java, and the venerated tomb which it shelters-that of the Susuhunan Bonang, one of the first and most ardent propagandists of Islam in Java.

Whether attracted by this sanctuary or by an active market, there is a colony of 5 II Arabs in Tuban, whose population is 24,500. It is the town in which the Arabs of the province chiefly congregate; but they are completely outnumbered by their competitors, the Chinese, who number 3,440. The bathing station of Bekti, or Bukti, which is a very short distance from the town, enjoys a certain reputation. Bodjonegoro and Blora (containing respectively $\mathrm{I} 2,560$ and II,990 inhabitants), both district capitals, are pretty towns, regularly laid out and engaged in various commerce; Blora in particular looks extremely charming in the midst of its teak plantations, which are the finest in all Java.

The Residency of Madiun, which has only a small seaboard on the Indian Ocean, between the Principality of Surakarta, the Residency of Rembang, and that of Kediri, has a particularly torrid climate. The capital, Madiun, contains 22,819 inhabitants, of whom 922 are Europeans and 1,827 Chinese. It is on the River Solo, in the great basin of Solo or Bengawan. Without a direct outlet, it dispatches through Rembang and Tuban the entire produce of this highly cultivated region. Ngawi $(8,533$ inhabitants), formerly a strategic position of value, which played a considerable part in the Javanese War, Magetan (I 2,768), and Ponogoro, are only local markets, well frequented by the natives. Magetan, at the foot of Lawu, is I,200 feet above the sea, which renders it more healthy than the surrounding country. 


\section{ADMINISTRA'TIVE DIVISIONS 87}

It possesses two sugar-mills. The capital of the remaining district, Patjitan (6,9 I I inhabitants), is within sight of the sea, without having direct access to it; it overlooks a wide bay giving safe anchorage, but is separated from it by a belt of muddy swamp, which is to-day transformed into a belt of paddy-fields, or sawahs.

\section{VI.}

The eastern portion of Java comprises the Residencies of Surabaja, Kediri, Pasuruan, Besuki, and Madura.

The Residency of Surabaja, in particular, is one of the wealthiest and most densely peopled of all Java; it is the superior of Samarang and the rival of Batavia. The capital, Surabaja, which was formerly the capital of all the Dutch settlements in the East Indies, has been forced to cede that title to Batavia, which is less populous, unless we include Meester Cornelis, and a less cheerful and active city. Surabaja is the commercial centre par cxcellence; of its I50,000 inhabitants 8,000 are Europeans, nearly I5,000 are Chinese, and some 2,800 are Arabs. At least four-fifths of the whole think of nothing but business, of buying and selling, the natives themselves having been drawn into the active commercial life of the port. Commerce is the chief occupation; the agreeables of life, which are by no means lacking, are only one of the results of this commercial activity, not the end of it. Oppressive though the climate may be, in Surabaja men work incessantly, without relaxation, and no city in the island gives a more vivid impression, an impression that is powerful in spite of its apparent vulgarity, of hard and fruitful labour. Hence the animation which one seeks in vain in old Batavia, where trade and fortune have the air of being dealt with in a more somnolent manner.

Surabaja is situated at the mouth of the vast alluvial basin of the Solo, and is actually built on the alluvial deposits of the river and its affluents, which are gaining slowly on the sea. But there is little reason to fear that 
the prosperity of the port may suffer ; for the port itself is at the mouth of the Kali Mas, or River of Gold, so called from the yellow colour of its water; and the Strait of Madura, which at this point, on account of its narrowness, has received the Dutch title of Trechter, or the Funnel, is sufficiently wide and sheltered from the winds to remain for many years to come the best and safest anchorage in Java.

Surabaja possesses a naval arsenal of the first class, with a gun foundry, naval ship-building yards, and docks, including a dry dock. Hundreds of Javanese artisans work under the supervision of European engineers and foremen in the Artillerie Constructie Winkel, one of the largest establishments in Java.

The Dutch Government had intended to surround Surabaja with a costly system of fortifications; but before they were finished the city, in the full tide of its growth, had burst through this too scanty garment; and it is extremely unlikely that an attempt which so miscarried will ever be revived.

The city is throwing out its new quarters, which are like so many towns with their own peculiar characteristics, along the two banks of the Kalis Mas, which are connected by the Red Bridge. Old Surabaja and old Batavia, with their stone houses with gables and cornices, their canals and their long main streets, where the houses stand closely ranked, remind one of the ancient cities of Holland.

In Surabaja, however, the Europeans have not abandoned the ancient city. Perhaps the luxurious villas, with their wide gardens, which are grouped about the Residency at Simpang, do not seem so much healthier than the old, sumptuous, gloomy buildings ; at all events, they migrate unwillingly.

The Red Bridge connects the European with the Chinese quarter. The unexpected cleanness and comfort of the latter witness to the wealth of the Celestials, and give one an idea of the important part which they play in the business world of Surabaja. The Arab quarter, 
infinitely less clean, and consisting of a jumble of sordid houses, shows that the Arabs have been forced in matters of commercial significance to yield the palm to the Europeans and Chinese.

Nearly all the elements of the Archipelago being represented in Surabaja, the native kampongs are many ; they have sprung up along the roads, or along the banks of the canals. There is the Malay kampong, the Sundanese kampong, the Javanese kampong, the Madurese kampong; and corporations or guilds will often result in a body of men living apart from the men of their own race, so that the kampong of the potters is distinct from that of the saddlers or the blacksmiths. This agglomeration of the most dissimilar types and races appears entirely natural in this energetic, bustling city, whose destiny has always seemed to be to dominate; and indeed the famous Indo-Javanese empire of Madjapahit, which was for a time supreme over the whole of Java, and which succumbed only in the sixteenth century under the blows of Islam, $\mathbf{r}$ had its rise at Modjokerto, some thirty miles from Surabaja.

Surabaja enjoys the glory of her bygone memories, the wealth and activity of the present, and a future which will keep pace and increase in importance with the more prominent part which the Archipelago will necessarily be called upon to play in the economic and political history of the Far East ; but she is lacking in two things, and it will probably be long before she obtains them : they are, namely, pure water and pure air. Madura, which lies facing Surabaja, and shelters the roadstead from the full violence of the winds, deprives the city of their cooling influence. The temperature of Surabaja is one of the most implacably torrid in Java. Drinkable water is more than scarce; the only water which wellto-do Europeans will drink is the Purut water, which arrives daily by train, in large iron tanks, from Pasuruan.

To these two disadvantages we must add the presence of a vast crowd of human beings, the majority of whom

' In 1518, according to M. G. P. Rouffaer. 
entertain the most absolute contempt for the laws of hygiene. Mosquitoes are a permanent plague in Surabaja, and only too often cholera bears them company. The kampongs of the natives are its favourite lurking-place, but the gay and aristocratic quarter of Simpang, which is doubtless too near the native city, is by no means safe from its visits. This is why people as a general thing avoid Surabaja, or only pass through it, stopping or settling there only under the imperious necessity of making or increasing their fortunes.

The various districts of the Residency of Surabaja all share to a greater or less extent in its prosperity and commercial activity. Djombang and Lamongan, the capitals of two of these districts, contain less than fifteen thousand inhabitants. Sidoardjo, which contains only I0,770, is known chiefly for the hot mud craters in the neighbouring hills; but Modjokerto and Grisei are of very different dimensions ; Modjokerto, containing 97,624 inhabitants, and the scanty ruins of Madjapahit, is a worthy attendant upon Surabaja; Grisei is a fallen queen, supplanted by the latter.

A long time ago Grisei was, it is true, the chief port of the east of Java, and the principal centre of commerce; to-day it is no more than a fair port of call for coasting vessels. Formerly it was a kind of holy city, whence Islam extended its domination over Java; where some pious and ambitious Mahomedans, probably from the outer world, founded a dynasty of priestly kings, whose moral power was still so great when the Dutch first settled in Java that the latter at first regarded them as the representatives of a Musulman papacy. ${ }^{\mathbf{X}}$

Of the Sunans of Giri no trace is left save the venerated tomb, on the hill overlooking Grisei, of their founder, Maulana Malik Ibrahim, and one relic still more extraordinary, the writing-reed, or stylus, of the pious ascetic, which, having served him to write the Koran, was transformed into a magic krees. This krees one day, in the

x Soesoehoenans or Soehnans. (See Veth, Fava, Ind. ed., vol. i., p. 236.) 
struggle between the Hindus and Musulmans, when the victorious people of Madjapahit were pursuing the latter through Giri, flung itself, at the prayer of the Sunan, against the Hindus, and effected a massacre, unaided and unheld. When it had swept the Hindus from the city it returned of its own motion, and received the name of Kjaï Kalam-munjeng-the Plain-Dealing Calamus.

Despite the decreasing importance of Grisei, a colony of nearly twelve hundred Arabs lingers there. It must be remembered that the bygone greatness of Grisei was due to men of their race and faith.

The province or Residency of Kediri, to the south of Surabaja, and washed by the Indian Ocean, is of a more distinctly agricultural character than its neighbour ; its towns are smaller and less wideawake, and are surrounded by huge plantations of coffee, fields of sugarcane, and bright green paddy-fields.

Kediri, the capital, has none the less a fair population : 40,200 , and of these 3,760 are Chinese, whose presence guarantees an active industrial and commercial movement. Kediri, indeed, is the temporary recipient of all the products of the surrounding region, which afterwards proceed to Surabaja by rail, or by the innumerable prahus which descend the Brantas. Kediri has also its workers in gold and silver, its coppersmiths, carpenters, potters, leather-workers, mat-makers, whose work has a considerable reputation; the city is divided into two parts by the River Brantas, which is crossed by a fine modern bridge. On the left bank is the Residency, imposing as always, in the midst of a park-like garden; here also is an old fort, and the finest of the European houses. On the right bank is the Regency, the native and Chinese kampongs, the old European quarter, and the only remarkable monument in Kediri: the ancient tomb of the family of the Regents of Kediri, known as the Astana Gedong.

At a distance of three miles, on the flanks of a hill called Gunung Klotok, are artificial grottos, Selo mangling, containing statuettes of Buddha, to which natives and Chinese carry offerings of fruit and flowers. 
The other district capitals, Ngandjuk, Tulungagung, Trenggalek, and Blitar, have less life and character among them all than Kediri ; but they are set in a gay landscape, so densely cultivated that the whole world seems a garden. Blitar has hardly yet recovered from the eruption of Kloot, which in 1875 covered it with a wave of boiling mud, which buried houses, plantations, and human beings.

The Residency of Pasuruan, which is in matters agricultural as wealthy as that of Kediri, is better provided with outlets. It is washed both by the Indian Ocean and the Strait of Madura, is closely connected by rail with the great market of Surabaja, and is also enabled to export its produce directly through its capital Pasuruan. At one time it seemed that the latter might rival or even be victorious over Surabaja. Its admirable anchorage was already frequented in the sixteenth century, and in the eighteenth century Pasuruan was the capital of the kingdom of Surapati. The Dutch reduced it to a more modest political position, but as lately as I860 it was still one of the four great commercial cities of Java. The construction of the railway from Malang to Surabaja struck it a mortal blow, as it diverted all the produce of the extreme east of Java towards its rival. Although a slight revival has been noticed of late, Pasuruan even now has only some twenty-eight thousand inhabitants; the fine houses built by the Europeans have been abandoned for a song to the Chinese, for which reason the Chinese quarter in this city has an appearance of wealth and comfort which one looks for elsewhere in vain. The Javanese and Madurese kampongs, near the great Pasuruan fish-ponds, are extremely picturesque. The Residency, the Protestant and Catholic churches, and a mosque with a minaret, have finally given quite a modern aspect to a somewhat sleepy and unprogressive town, while they also mark the mixture of races and beliefs.

Pasuruan is chiefly occupied in exporting coffee, sugar, and fish, the latter to Madura. A little way outside the 
town is the factory where the pure waters of Purut (Poeroet) are bottled, and a Government laboratory where experiments are conducted referring to the culture of sugar-cane.

Bangil, a district capital in this Residency, with 17,866 inhabitants, of whom 856 are Chinese and 844 Arabs, is far more active; Lumadjang (I6, I28 inhabitants), and Kraksäan $(3,667)$, situated in two other districts, serve as temporary points of concentration for all the agricultural products of a most wonderfully fertile district.

But the pearls of this province, which is itself one of the jewels of Java, are Probolinggo and Malang, one on the north end the other at its eastern extremity.

Probolinggo, or Banger, as the natives call it, from the name of the river at whose mouth it is built, is on the Strait of Madura. It contains 14,560 inhabitants, of whom 2,590 are Chinese and 35I Arabs, while the Europeans hitherto have not exceeded 588 in number. In 1895 it possessed only 8,705 inhabitants. It has thus nearly doubled its inhabitants in fifteen years. It is well and regularly built, pierced by wide streets running at right angles, which are shaded by groups of evergreen trees : tamarinds, banyans, and others : and the general aspect is extremely attractive, the town being clean and cheerful. The harbour consists of a great oblong basin, on the quays of which are erected the warehouses where the final handling of coffee, sugar, and tobacco takes place; and there the vessels lie moored. At the entrance to the harbour is a long mole surmounted by a lighthouse.

Probolinggo is also the centre of a genuine intellectual movement, being one of those cities which are playing a prominent part in the Javanese renascence. It possesses also a college for the sons of chiefs, and a Normal College for native teachers, who represent the Government's sole effort in the province of education. The number of students is necessarily increasing; so that although Probolinggo is no longer, as in I900, the capital city of a province, being reduced to the status of 
district capital, it still has all the attractions of a small capital.

Malang is far better developed. A second-rate, overgrown village ten years ago, it now surpasses Pasuruan, the official residence, in commercial activity, and will, to all appearances, continue to do so for many years to come. It also surpasses it in charm. It is situated at the base of the Tengger range, in a magnificent plain, the horizon of which is enclosed by what are perhaps the finest volcanoes in Java: Bromo, Ardjurno, and farther to the south-east the majestic Semeru, while at the back is Kawi. Thanks to an altitude of 1,460 feet above sealevel, Malang enjoys an agreeable climate, the temperature not exceeding $80^{\circ}$ in the day, while at night it may fall to $6 \mathrm{I}^{\circ}$. Although not absolutely free from the paludian fevers which infest all Java, rising from her low-lying plains and her swampy girdle of sawahs, Malang knows them only in an attenuated form, and is a salutary refuge for those suffering from anæmia or exhausted by the torrid sunshine of the Indies. All green and white, in the midst of a valley which cultivation has turned into a garden, Malang affords at the end of every street the splendid panorama of the mountains. The aloun-aloun, waringins and mango and breadfruit-trees growing along its borders or scattered in groups in the open, is surrounded by the Assistant Residency, the Regency, the mosque, the necessary public buildings, the church, and all the signs of organised and official life ; the native and Chinese kampongs hang upon the outskirts of this aristocratic quarter, making the suburbs of the town, so that the eye enjoys them while the sense of smell escapes offence.

The prosperity of Malang dates from the cultivation of the entire district, which is one of the most fertile in Java. In 1808 it contained about thirty thousand inhabitants ; to-day there are half a million, most of whom are occupied in planting and harvesting coffee and sugarcane, and to these we must add, at the period of harvest, a floating population of nearly a hundred thousand 


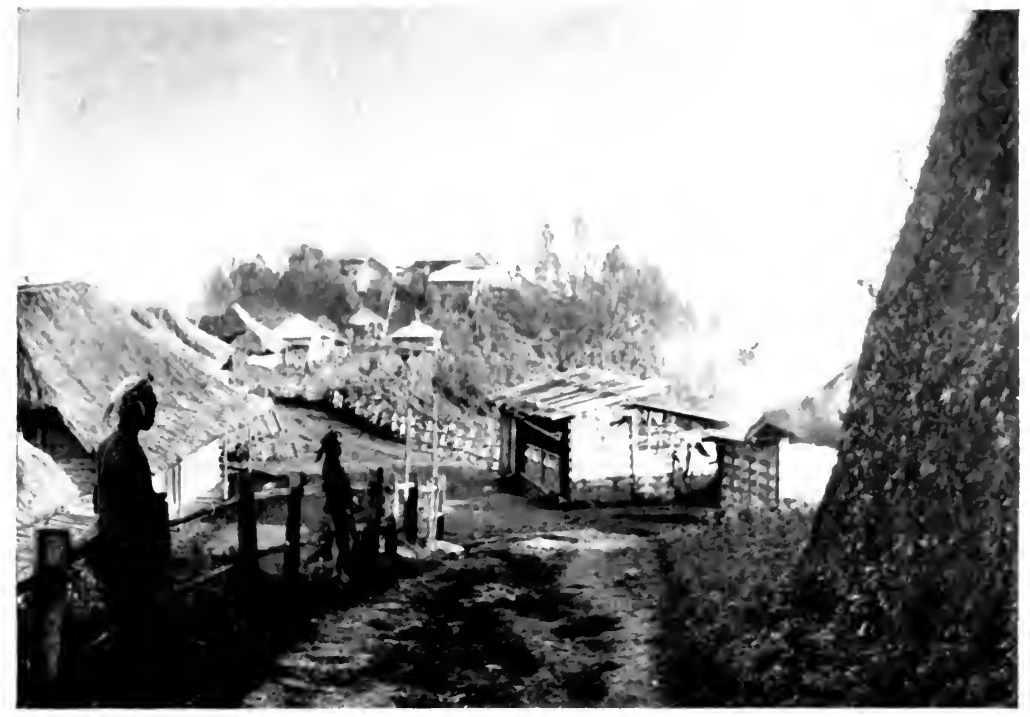

THE HILL STATION, TOSARI.

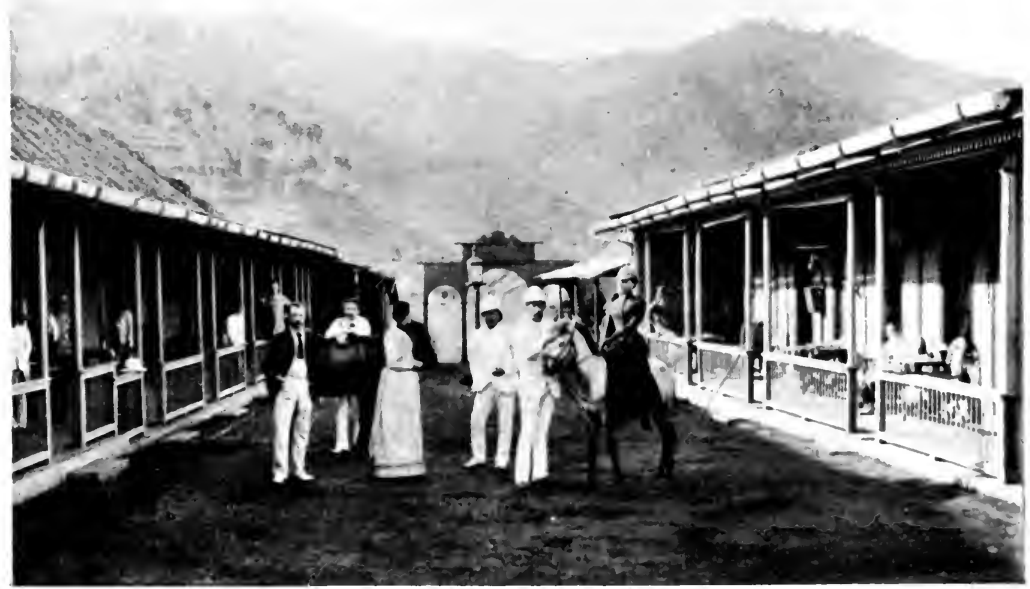

THE SANATORILI, TOSARI. 

workers who flock from all parts of the island to earn the handsome wage of two and a half florins a dayequivalent to four shillings and two pence, or an American dollar. The city itself, which was a poor village only twenty years ago, to-day possesses 29,540 inhabitants, which number includes a colony of 1,353 Europeans, which is much larger than the colony in Pasuruan, one of 3,537 Chinese, and one of 342 Arabs. During the harvest season the activity is intense ; on all sides one meets with nothing but loads of coffee or sugar-cane; in September a complete train of this latter product leaves the railway station every ten minutes, to feed the sugar factories and refineries of the island.

Malang, in spite of its wealth and its beauty, is surpassed in attractiveness by Tosari. Without being even a district capital, this beautifully situated village is a hygienic paradise for all the sick or convalescent of Java. Nearly 600 feet above the level of the sea, in the mountains of Tengger, built on a foundation of dry, sandy ashes, Tosari is the most invaluable sanatorium in the whole of Java. Indeed we may say, despite the merits of Sindanglaja and Garut, that it is the only sanatorium that really deserves the name; since it is the only one, in the general opinion, at which one is absolutely safe from fevers; cholera, dysentery, and beri-beri have never been known there; and in default of Europe it is the objective of all the convalescents and consumptives of Java. It is unsuitable only for rheumatic, cardiac, and nervous patients. The temperature never rises above $79^{\circ}$, and the average is $62^{\circ} 6^{\circ}$ : the nights are so cool as to procure one the luxury -a delightful one in the tropics-of being able to sleep between the bedclothes instead of on the top of them. The flora, the Alpine character of the landscape, the torrential rivers, and the bracing sweetness of the air give one the impression of being transported suddenly into Switzerland; and the Tenggris villages which cover the slopes near the sanatorium give a touch of the unreal and the picturesque. 
The Tenggris and their goats, which wander all day long, with tinkling bells, in the forests of chemaras 1 those tropical pines which are three times the height of ours-take shelter for the night in villages of rustic wooden huts with roofs of thatch, which are defended by strong palisades of interlaced bamboos; the only thing they have forgotten to borrow from the Swiss is cleanliness. But they are loyal, active, good workers, 2 hospitable, and unusually moral; they are stronger, browner, and shorter than the Javanese of the plains. They number some five or six thousand, and are scattered among some fifty villages. They marry only among themselves, and are firmly attached to their ancient faith : the worship of Shiva, greatly corrupted by animistic practices. Each year they celebrate a slamettan, or sacrificial repast, ascending for that purpose the Dasar, on the flanks of Bromo or Brahma, to whom they make oblation of rice and fruits, in place of the human sacrifices which, it is said, were formerly offered. All this district has remained strongly impregnated with Hindu beliefs, which flourished with a vigour that is still attested by the curious ruins of Singosari, at a distance of some six or seven miles from Malung, and those of Tumpang, which are about fourteen miles from the same city. 3

The Tjandi Singosari, or "Temple of the Garden of the Lion," is a graceful structure in three stories, of which the highest, which rests upon a square terrace, has suffered the worst damage. The interior sanctuary, with its finely carved outer walls, is now empty; but it probably contained an image of some deity of the

× The chemara, or tjemara, is a tree of the Casuarinæ family. One species, the Casuarina $\mathcal{F}$ unghuhniana Miq., is found most commonly on the summits of the volcanoes of Eastern Java.

2 The Tenggris are now in certain localities cultivating the ordinary potato with considerable success.

3 The Tenggris, or Wong Tengger, literally mountaineers, highlanders, form, according to Mr. G. P. Rouffaer, the only actually surviving trace of the civilisation of Madjapahit in its latter period. (See Tenggereezen, in the Encycl. v. Ned-Indië.) 
Brahministic pantheon; probably one of Shiva. Not far away, in the shade of a crescent-shaped grove of coco-palms, are two statues some 8 or 9 feet high, of Shiva and Ganesha, erect upon their altars.

The ruins of Tumpang, in a still more pronounced condition of dilapidation, rise from the midst of a magnificent grove of bamboos, areca-palms, and banana-trees. The form of the temple is that of a pyramid built in three stages, with terraces accessible by flights of steps. The stairs leading to the first terrace are guarded by rakshasas, and a motive of animals, men, and plants, carved with admirable art and patience, runs along the outer friezes. The force of the vegetation, even more than the forgetfulness of man, has been responsible for the destruction of this rare work of art. Palm-trees and lianas have disjointed the stones with the slow, irresistible pressure of their roots; the delicate chiselling is corroded by moss and lichen. If the Government does not take means to preserve them as it has done at Boro-Budur, the ruins will in time disappear under the victorious assault of the vegetable world.

The province of Bezuki, or Besuki, holds a modest place as compared with Surabaja and Pasuruan. The city which has given the province its name, and of which it is the capital, is hardly more than a district centre; it is merely a great village of five thousand inhabitants, not far from the sea, but untouched by the commercial current of East Java. It has been supplanted by Bondjowoso, which apparently owes its good fortune solely to its position on the railway. Built in a valley of the great plain of Panarukan, near the Sampejan or Panarukan River, it has only some 8,700 inhabitants, but it contains a few important sugar and tobacco houses.

Djember and Situbondo, both district centres, are developing very slowly, despite their plantations of coffee, tobacco, and sugar-cane. Djember has now only 7,790 inhabitants, and Situbondo, which in 1895

- Among the Hindus, a kind of demon; here, guardians of the temples, of grotesque and terrible aspect. See Introductory Chapter. 
contained ro,690, has now no more than 6,r5o. Its traffic has been taken by the port of Panarukan, which was the first station of Alfonso d'Albuquerque in the sixteenth century, and at that time was one of the great markets of Java ; to-day it merely exists, as it has few outlets, all the important trade of the East having left it for Surabaja, Probolinggo, or Pasuruan. The only town of any importance in the province (and that is important only by comparison with the rest) is Banjuwangi, which is built upon the narrowest part of the Strait of Bali. This port used at one time to be frequented by a great number of sailing vessels. Although the town has greatly suffered inasmuch as it was finally decided that the railway which serves Java from east to west should not pass through it, it has derived some compensation from the fact that it is a point of call for the steamers which run between Surabaja and the smaller of the Sunda Islands; and it is also the point of junction of the international cable line between Australia and Batavia. The city, whose title signifies "Perfumed Waters," hardly merits it as far as the dirty native kampongs are concerned; but the old Residency, occupied now by an Assistant Resident, and the European quarter on the Sukaradja hill, enjoy a magnificent view of the Strait of Bali and the surrounding country. The population to-day is $r 8,732$, of whom 256 are Europeans, 569 Chinese, and 543 Arabs.

The last of the seventeen Residencies of modern Java is constituted by its neighbour, the island of Madura, in which the Dutch Government substituted its own authority, without warfare or serious difficulties, for that of the native princes, or Panembahan, between the years of 1883 (when it took over Sumenep) and 1885 (when Bangkalan was taken over).

The capital of Madura, Pamekasan, is a small town of only 8,440 inhabitants : but although small, it is clean, pretty, and is rapidly improving. The Residency is luxurious and its gardens delightful; the Regency, installed in the huge old kraton, retains a princely charm which flatters the feelings of the natives. A tramway 
connects Pamekasan with Bangkalan, Sampang, and Sumenep.

Sumenep, in the east of the island, is a district capital, and the seat of an Assistant Resident and a Regent. It was formerly the seat of the Government of Panembahan. It is the largest town in Madura, with its 17,930 inhabitants ; but it appears to have seen its best days, as in 1900 the population numbered 20,020. The Madurese, who are robust, hard workers, and very frugal, are continually flowing into Java, where the spread of cultivation in the eastern provinces assures them of well-paid labour. From Surabaja to Malang, and as far as Panarukan, one meets them working for and highly appreciated by the foreign element, whether Chinese or European. Sumenep, whose dwellings are scattered over a very large area, contains nothing worthy of remark, save the house of the Assistant Resident: a modern building which the people persist in calling a kraton; and the unusually fine memorial monument which the last Panembahan of Madura has built in honour of his family. The native industries are actively pursued, and articles used in fishery and navigation constitute a comparatively lucrative trade. Along the shores of the bay, at the edge of the rice-fields, are the villages of the salt-workers, who live by producing salt for the State.

Sampang, another district centre, contains 8,924 inhabitants, living in bamboo houses, and eking out an existence by local trade. Bangkalan, in the west of the island, is the remaining district capital, with a population of 14,318 . It has a fairly good harbour, and owes its present importance to Surabaja, as it formerly owed it to Grisei. It exports to the great commercial capital the best products of Madura : animals destined for the butcher, fruits, swallows' nests, vegetable down, bark for tanning, and certain articles carved or chiselled by Madurese artisans; it receives in return rice, and European manufactures.

To sum up : Java retains, throughout all her administrative divisions, the aspect of a country pre-eminently 
agricultural. Her overpeopled territory contains only three large cities (in the European sense of the word); two ancient native capitals; many pleasant, overgrown villages which are spoken of as cities; and innumerable dessas, or hamlets, which are lost among the countless plantations, and whose inhabitants live close to the soil to which they look for all things. 


\section{CHAPTER V}

\section{THE NATIVES OF JAVA}

I. Distribution of the native element in Java: the Sundanese and Madurese compared with the Javanese.-II. The Javanese.III. The Javanese house and village.-IV. The family and marriage.-V. Daily occupations; agricultural labour, hunting, and fishing.-VI. The batik industry: Javanese clothing.VII. The love of pleasure, and the means of satisfying it: betel-nut, tobacco, opium and hemp; cock-fighting and gambling.-VIII. Failings with which Europeans reproach the Javanese ; nearly all of which have some historic excuse.

I.

OF the 30,098,000 inhabitants which people Java and Madura, 29,7 I5,900 are natives, 293, I90 Chinese, I9,I48 Arabs, 2,840 Oriental foreigners, and 64,917 Europeans, or men of European descent.

These natives are not all Javanese. The ports contain some 300,000 Malayan immigrants; in Batavia the Malays are especially numerous, and even outnumber the Javanese. The Sundanese, whose numbers vary between two and a half and three millions, are found in the western part of the island, but seldom cross a line drawn from the mouth of the $\mathrm{Tji}$ Tanduwi, in the Gulf of Cheribon. Their headquarters are the Residency of Preanger, but they overflow thence into the province of Batavia, the district of Krawang, and the southern portion of Cheribon.

The Madurese, who slightly outnumber the Sundanese, inhabit Madura, and form almost the entire population of Probolinggo and Besuki; they are also numerous in Pasuruan. The Javanese occupy all the middle of the 
island, from Cheribon to Surabaja, including Pasuruan, where they come into contact with the Madurese.

We can hardly mention the Kalangs beside these three large groups. They form a mere handful, and they used to live a wandering life, drifting all over the island, until one of the last Sultans of Mataram, in the eighteenth century, tied them down to fixed localities, or reservations, known as "Kalangans." The Kalangs are found throughout all Middle Java, but especially in the Vorstenlanden of Djokjakarta and Surakarta, where they live apart in villages of their own. Although their origin remains in obscurity, it has been the subject of the most fantastic legends, born of the imagination of the Javanese, who sometimes represent them as born of the union of a princess and her own son, and sometimes as descended from a man and a dog, whose tomb may still be seen in the village of Praguman (in the Residency of Samarang). Everywhere to-day these gipsies of the Far East have settled down to a sedentary life, and have become merchants, coppersmiths, makers of rattan cord, coopers, \&c. This latter trade they carry on to the profit of the prince, as compulsory labour. At Surakarta they are most usually wood-cutters, cabinetmakers, and carpenters.

They adhere to certain characteristic usages in the event of a wedding or a funeral; in which the dog appears to play a limited part, presumably totemic ; a fact which has given rise to the absurd accounts of their origin. Although certain ethnologists are inclined to proclaim their affinity with the Negritos of the Philippines, and although the populace even now pretend that they are often fitted with a caudal appendage, ${ }^{x}$ and practise intercourse with their children, the Kalangs are in reality hardly to be distinguished from the Javanese,

- A similar belief is held by a number of Asiatic peoples. The Annamites, for instance, are persuaded that certain moïs or savages of Indo-China are provided with tails. Respecting Tailed Men, see G. E. Gerini, "Researches on Ptolemy's Geography of Eastern India " (London, 1909), p. 687, No. 5, and Index. 
whose language and dress they have adopted; they are nearly all circumcised Mahomedans, and frequent marriage is gradually absorbing them into the Javanese race.

As a matter of fact, the Javanese, Sundanese, and Madurese appear to have formed one single race originally, and to have evolved in slightly different directions, under different historical and climatic conditions.

The Sundanese, the most sturdy of the three races, have the appearance, the virtues, and the faults of highlanders. Taller, stronger, and more energetic than the Javanese, living in huts supported on piles, and addicted specially to agricultural labour, they belong to a civilisation distinctly inferior to that of the Javanese. They are conscious of the fact, and are proud or servile according to the circumstances. In the cities, such as Batavia and Krawang, they tend to assimilate the Javanese civilisation; but in their mountains, where they live by agriculture or the chase, they have the name of being honest, loyal, subject to tradition, and of a deeply religious habit of mind; although their Islamism, being modified by the memories and the rituals of bygone cults, is of a doubtfully orthodox type. But outwardly they have been far less influenced than the Javanese by the Hindu and Arab civilisations; their rude language is far poorer in Sanscrit terms than the Javanese tongue, and in Persian or Arabic words than Malay. In the valley of the $T \mathrm{ji}$ Udjung there is even a small group of Sundanese who profess a kind of animism, barely touched by vague Buddhistic beliefs.

While the Sundanese are tending towards absorption by the Javanese, the Madurese are successfully retaining their rugged and forceful characteristics. The Dutch regard them as among their best, though not perhaps their more tractable colonists. The native of Madura, sometimes a merchant, more often an agricultural labourer, is headstrong, vindictive, over-ready to draw his krees ${ }^{x}$ to avenge the slightest insult, little amenable

' At one time it became necessary to forbid the Madurese to carry arms, on account of their hastiness in using them. 
to advice, and always impatient of the yoke. On the other hand, he is laborious, frugal, and has more foresight than the other natives of the Archipelago; and with these virtues goes the spice of parsimony and surliness which commonly accompanies them. He allows no one to infringe his rights, nor to subject him to any accusation which seems to him unjustified; he has a horror of enforced labour, yet he acquits himself more fully than any one in Java of his debts toward the Government in kind, money, and the corvée. His loyalty is well tried, if not demonstrative; but he is grateful to his European masters for having introduced a reign of security, so that he can till his field in peace. $\mathrm{He}$ has the name of being a good Mahomedan.

\section{II.}

The Javanese, of the three races, is the slightest in build, the most graceful, the most cultivated and sociable. The Javanese represents two factors which take precedence of all the elements of the island life: the factor of numbers and that of a more refined civilisation. Although his mentality has been enfeebled by long centuries of servitude and chronic poverty under greedy and despotic Governments, conditions from which it is barely beginning to recover, the Javanese possesses the memory of a glorious past, which results in a feeling of pride untouched by the shadow of sedition. He has also retained a really open mind, a remarkable faculty of assimilation, and the complex and exquisite politeness of a man of ancient race, who may have lost his prerogatives, yet retains his air of being good company. He renders every man his due, while he himself is ready to feel deeply wounded if any one subjects him to uncalledfor rudeness.

\section{III.}

Agriculturists by destiny, and passionate lovers of their soil, the majority of the Javanese live in villages or 
kampongs, ${ }^{\mathbf{x}}$ which, considered as social and administrative units, are also called dessa. These villages may contain from thirty to five hundred inhabitants. In the towns the Javanese, like all other natives, as well as the Chinese and Arabs, flock together and live to themselves, thus forming a special quarter, which in turn is often subdivided into many sections by the various bodies of trade craftsmen, who foregather and live together. The Javanese kampong nearly always has the appearance of a beautiful grove of coco and other palms, which shelter the slightly-built wooden huts, which indeed are hidden from view at a short distance. In the midst of the well-kept and slightly formal plantations which surround it on every side, the kampong has the look of a piece of woodland; slightly thinned, but picturesque in its very irregularities. Some are still surrounded by a palisade of interlaced bamboos, which marks the limits of the village, and constitutes an outer defence; but the majority to-day are open, and the houses are surrounded by hedges of bamboos, or sometimes of coffeetrees, which serve the purpose of effectually dividing the enclosures, while the outer sides of the hedges, being continuous, enclose the entire village. The Sundanese, in their mountain hamlets, still build their houses on piles; but the Javanese are content to build them upon beaten earth, which is slightly raised, and serves as the floor of the house when the latter is completed. When this precaution is omitted the soil remains damp, sticky, and extremely insanitary. The Javanese custom of beating the soil is attributed to Hindu influence, as this style of construction is usual in India. The langgars, however, or domestic oratories, are commonly built on piles.

We must not expect from the Javanese dwelling any great variety or elegance of form. In the tropics, and especially in countries where the natives live largely out

"Kampong signifies both "quarter" and "village" ; it is a collection of dwellings. Dessa includes the inhabitants, their dwellings and the political community which they represent. Dessa is the Sanscrit des $a=$ place, region, country. 
of doors, and often move from place to place, the house is not a matter of great importance. It has no chimney; the smoke escapes as it can. There are practically no windows, or none as we understand the term; light enters the house usually by the door, or through the loosely-wattled walls of bamboo, except where the interstices are filled with leaves; so that even at noon the native hut is dark, and the smoke takes one by the throat. The Javanese endure the smoke with exemplary patience, regarding it as the best defence against the superabundant mosquitoes. With this object, indeed, a small fire is always kept burning in the Javanese hut; and on cold nights the natives sleep on their mats beside the fire. The Javanese house never contains an upper story; occasionally, but only in the houses of the more prosperous natives, there may be a small granary for maize, situated between the ceiling and the ridge-pole of the roof. Built of teak, "wild-wood," the wood of the cocopalm (glugu), or bamboo, according to the locality, and roofed with shingles, alang-alang, , or nipah-thatch, the light and simple dwellings of the natives have nothing to fear from the earthquakes, which in this volcanic region are so frequent. In the case of prosperous householders the dwelling usually consists of three distinct structures, each with a roof whose ridge-pole turns upward at the extremities; and the three buildings are often connected by means of corridors.

The first structure is the pandopo (pendopo, pendoppo), in which guests are received, meetings held, and feasts are given. The central part is the pringitan; there guests who are stopping the night or making a stay are accommodated, and there on certain occasions the wayang will give its performances; the third structure is the omah, reserved for the members of the family; this is the actual

- Alang-alang (Javanese), or lalang (Malay), the Imperata arundinacea Cyrill.

2 Nipa fruticans Wurmb. (Palms). The term atap is given to the alang-alang as well as to the leaves of the nipah when these materials are used for roofing purposes. 
dwelling-house. To the left, as a rule, of the pringitan, in an annex covered by the same roof, is the kitchen, the bath-room, and a small apartment used for grinding rice. Behind this building is the byre for the buffalo and the cows, and further still in the rear the horses are stabled. To the right of the pringitan is the big granary for the rice, the door of which is above the level of the ground; behind it, and farther away, is the langgar (oratory) where the Koran is taught to the children, and to which the women are admitted from time to time in order to offer up their prayers.

Among the peasants the house consists of two parts only: the pandopo, which serves the purpose of the pringitan; the omah, where the family lives, and which serves also as the kitchen, and a storehouse for the implements of field labour. In these two primitive types of habitation the Javanese, whose love of specialisation knows no limits, profess to distinguish four architectural types, in which there are certain differences of ornamentation, dimensions, and material; and these four types may themselves be sub-divided into eight or ten varieties, all having individual names; it is, in short, a case of a great deal of sublety for a very slight difference.

Compared with the house, the furniture is rudimentary. There are wooden bed-frames, mats of every form, colour, and value, the uses of which are innumerable; vessels of various kinds in baked clayand in copper ; kitchen utensils, articles for table use, tea-service and tray, sirih sets, ${ }^{\mathbf{I}}$ cushions, screens, coffers to hold clothing, lamps of earthenware and metal, including, in the houses of chiefs, the modern hanging type; porcelains, baskets, panniers of woven bamboo, fishing and hunting gear, agricultural implements, \&c. The numbers of objects, the quantity of metal employed, and the fineness of the work are, as everywhere, proportioned to the wealth of the owner.

- These contain all that is required for the preparation of the betelnut for chewing. Such sets are made in gold, silver, copper, or simply in plaited cane or reeds. In Malay betel is called sirih. 
Thus built and furnished, and fronting on a few flowerbeds, square plots of kitchen herbs and vegetables, surrounded by fruit-trees, mangoes, coco-palms, bananas, and separated from the road and from its neighbours by a thick hedge, most often of bamboos, the Javanese dwelling-house has a cheerful, primitive aspect, and a certain air of being only a temporary shelter.

A group of several alleys of such houses constitutes a village, in the centre of which is the aloun-aloun, a small open stretch of turf, where the market is held. The house of the chief or headman of the kampong generally overlooks the market-place. A drum which serves to mark the hours informs the villagers of the flight of time, or warns them in case of alarm. There they live in peace under the order of a chief elected by themselves : the only political right which has been left for them to exercise. $x$ He governs them according to the principles of a law admitted by all : the adat, which is a mass of old customs and racial traditions. This law, which must not be confounded with Mahomedan religious law, is often opposed to it, and only gives way to it in matters purely theological or questions of ritual. The adat, or custom, and the cheriat, or religious law, and the suzerainty of the Dutch, exercised through the intermediary of the native aristocracy, are the three ruling forces in the social and political life of Java.

In the event of conflict among themselves the natives are judged, under the supervision of an European judge, by a native judge, whose duty it is to explain and apply the law of custom, or adat. It goes without saying that in cases where the law of custom would violate the humanitarian principles of the Europeans, the Dutch official would intervene in order to soften it somewhat, and a sentence is never pronounced without his approval. As a matter of fact it is always he who delivers the final

× The election must be ratified by the Dutch Resident, who at need rejects persons of infirm health, smokers of opium (hemp ?), notorious misers, and in general those who are mentally or morally or physically deficient. 
judgment, although through the medium of the native judges or chiefs.

In the event of litigation between natives and Europeans, and in cases in which the European has committed the offence, the latter is subject only to the Dutch police and the Dutch law, but the latter takes into account the manner in which the defendant has violated the law of adat.

It is a curious thing that the natives of this country, despite the wave of Buddhism once swept over it, and notwithstanding their usually gentle character, are unfeeling where animals are concerned; excepting as regard the buffalo, the indispensable companion of their labours, and the game-cock, the instrument of pleasure and of gain.

IV.

The family in Java is very firmly united. A keen affection binds the Javanese to his own. Extremely prolific-to judge by the alarming increase of the population, the most prolific father in the world-the number of his children does not decrease the strength of his affection. Long accustomed to a happy-go-lucky existence, and to poverty, the increase of his family gives him none of the bitter anxiety of our modern proletariat. It costs so little to live in Java that the children will always have enough to eat; and, as in India, fecundity and sterility are regarded as the especial marks of God's approval or displeasure. Sons and daughters alike, the Javanese father treats his children with the greatest tenderness; caressing them often, protecting them from harm; and in return the children manifest the greatest deference to their parents, and where needful support them and see to all their needs, so that the law has no need to intervene. Such behaviour is prompted both by the adat and their own hearts. Although the religious law permits polygamy, the Javanese leaves the practice to the wealthy and eminent; regents, vizirs (patih), or even 
district chiefs or headmen (wedonos) ; but even these, in imitation of the Europeans, are tending to limit themselves to monogamy, at least officially. Thus poverty on the one hand and snobbery on the other, despite the influence of Hinduism and the Musulman law, are uniting to restore the women of Java to the place which is due to them, and which will make for the better progress of the race. The adat, in this particular, has exercised an excellent influence; the moral and material situation of woman among the Malayo-Polynesians has always been a high one, the matriarchate, with all its consequences, having for a long period been the basis of Malay society, and among the Negri Sambilan of the Peninsula it is still practised.

This is why, in spite of Islam, the Javanese woman goes abroad unveiled, shares the interests of her husband, has her place at festivals, and speaks freely at home. Both wife and husband, moreover, so continually work side by side that this community of labour strengthens the position of the Javanese woman, although this does not equal that of her European sisters.

The Javanese marry early, and celibacy is as unknown as it is inconvenient. Where the daughter is of nubile age-say twelve or fourteen-and the boy about sixteen, the parents begin to confer with a view to discussing their union. It is only after the parents have agreed that the two young people are allowed to see one another. Then, although the bridegroom's consent is necessary, that of the daughter is not indispensable. It is true that the affection of the parents nearly always modifies the rigour of the law upon this point. A pledge of betrothal, consisting of jewels and food, is then offered by the boy's parents to the girl's, who also receive, a few days later, the "price of purchase" of the bride, or the tumbassan, composed of silver, household utensils, or furniture, cloth and other stuffs for clothing, rice and game, the quantities varying with the rank of the betrothed couple. To these is added a special present for the parents. On the day when these presents are received the parents of the two 


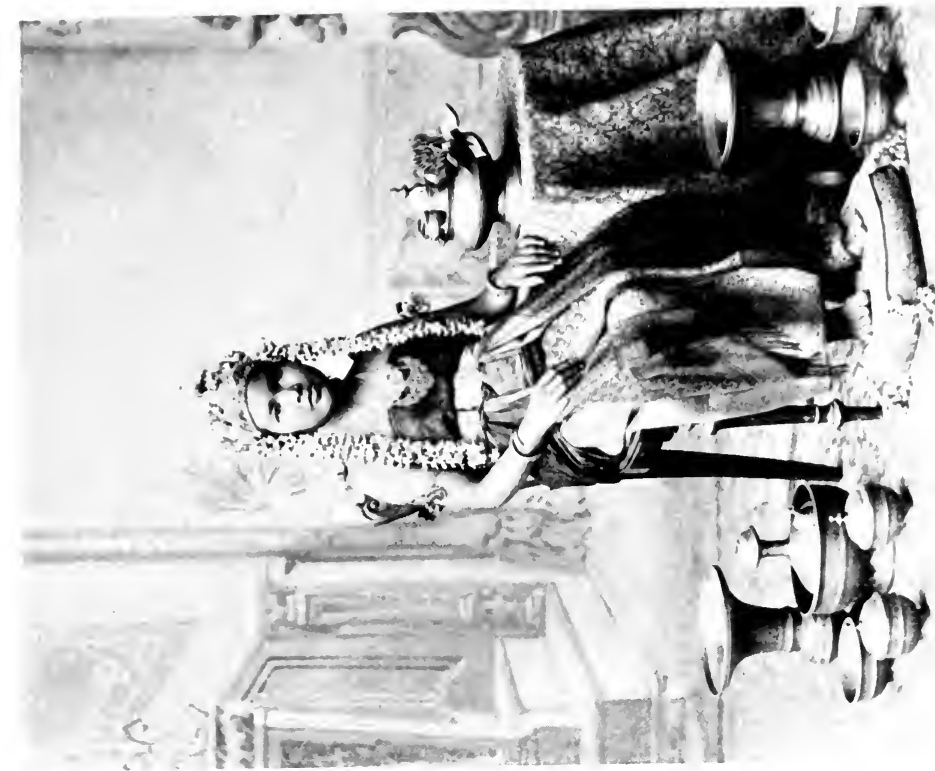

告

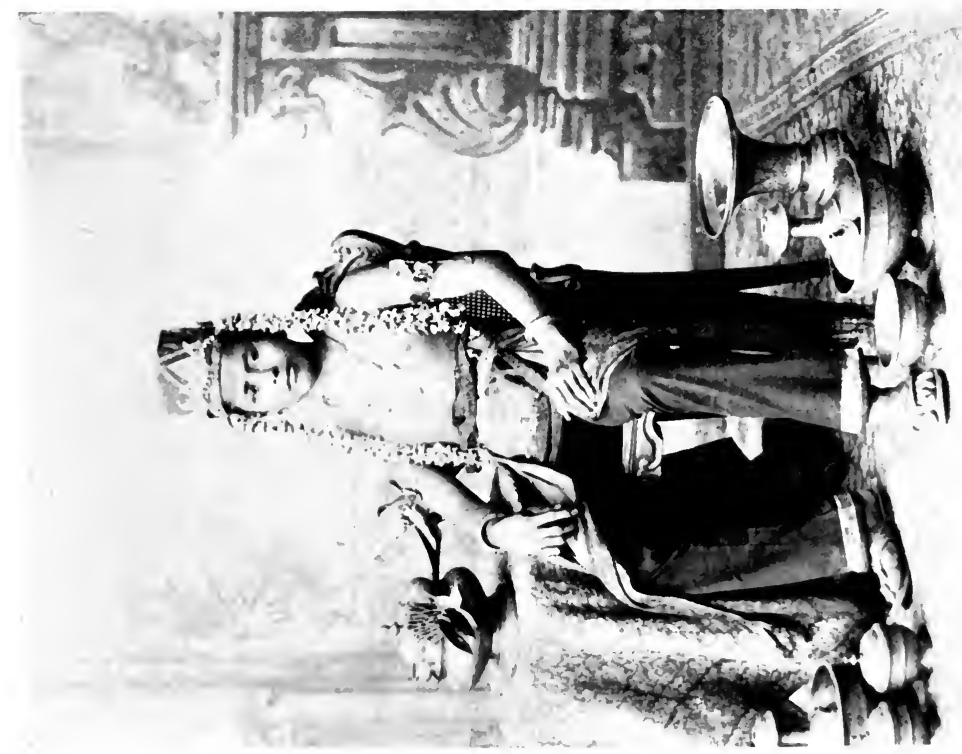

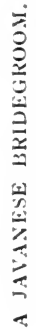



young people are expected to send to all their relatives, friends, and superiors-one might almost say to every inhabitant of the village-a small present of food and an invitation to attend the family gathering, which will last for one or for several days, spent alternately in the houses of the boy's and the girl's parents. A marriage in Java, as among all races whose manners are still simple, cannot take place without repeated banquets, which nearly ruin the young couple and their parents, but which leave them, at least, the consolation of regaling themselves as generously at the very next marriage of a member of the community.

The night preceding the wedding must be passed in vigil by the future spouses, or some great unhappiness will overtake them. On the following day the wedding is celebrated in the mosque according to the customary ritual of Islam. The bridegroom, in resplendent clothing, his face rouged, surrounded by all his relatives and friends, preceded by strident music, proceeds to the mosque, while the girl, who is confined to the house, is represented at the mosque by her wali, or tutor. Then, having re-entered his own house, the young bridegroom exchanges his court dress for another costume, which is often as rich, but less solemn in effect, and proceeds with due ceremony with all his attendants to the wife's home, where she awaits him, decked in her finest raiment, rouged and painted, the upper part of the body and the arms bare, and well rubbed with boreh.x

To symbolise her complete submission to her husband, she washes his feet, and is then led by him, in procession, to the home of her new relations, where a well-covered table awaits the invited guests. On the following day another feast is held at the house of the bride's parents; on the third day the young people have the right to withdraw and settle down in their own house, if they have one; sometimes, despite the gorgeous clothing and the

'A mixture of saffron and poppy oil, which is employed in Java to stain the upper part of the body yellow, that portion being left bare on certain solemn occasions. 
sumptuous feasts, they are too poor to possess a home of their own, in which case they settle down with the wife's parents until they have found the means of procuring a separate house.

V.

As Java is nothing else than a vast plantation of rice, coffee, sugar-cane, tea, quinine, indigo, \&c., the Javanese native leads a purely agricultural existence. He devotes himself especially to the cultivation of rice; for while other crops yield him a little profit and his masters a very large one, it is the rice-crop alone that nourishes him. Rice is his staple, indispensable food; and it is a common saying that if, upon rising from the most copious banquet, the Javanese has had his accustomed allowance of rice, he will declare that he has not eaten.

The cultivation of rice, be it said, is no easy task. In transplanting rice the native works all day kneedeep in slippery mud, which is rich in noxious gases, and the home of the deadly mosquito; while at the period of harvest he is forced to work for days together in a stooping position, as the ears are cut off by hand, instead of being reaped with a scythe, as corn is harvested in England.

The industries arising from the chief crops of Java - the preparation of tobacco, tea, indigo, and coffee, and the manufacture of sugar, which have made great strides since the extension of the system of free labour -employ considerable numbers of natives. They are docile and skilful, but one can hardly say that they are always energetic.

The Javanese, according to general testimony, is not a born worker. He can live on a handful of rice and a little fruit, which diet he can obtain without effort, almost by the mere fertility of the soil. As his desires are practically limited to the bare means of subsistence, he would prefer to limit his labour. He would rather diminish his requirements and at the same time 
his exertions than to labour with a view to creating new necessities and to gratify them. This philosophy, however it may disarm the psychologist, is, we must admit, extremely irritating to the colonist, and in absolute contradiction to the feverish activity of the West. Perhaps we should attribute the very real apathy of the Javanese, as of many other Asiatics, to the fact that he has laboured incessantly for centuries, but never for himself. $\mathrm{He}$ is, therefore, not indifferent to the soil, to which indeed he is passionately attached, but he is weary of fruitless labour. When he is able clearly to understand the evils to which his lack of foresight may expose him, and is convinced of the possibility of enjoying the fruits of his own labour, there is a probability that he will bring to that daily labour the enthusiasm of which he so often gives proof in matters of his own intellectual development.

Besides cultivating his rice-field and his little orchard, the Javanese habitually increases his store of food and of money by fishing and hunting. Hunting, however, plays a much smaller part in his life than fishing, provided that he lives near the coast or some large river. There are several reasons for this; hunting is nearly always harder work, and more uncertain than fishing; moreover, the dense cultivation of the soil in Java has made game less plentiful than it used to be; and the laws of Islam forbid the consumption of the flesh of certain animals.

The hunting of the larger wild animals has diminished because many of them have become rare, and because, for instance, the natives have noticed that where the tigers and other large cats are hunted too vigorously, the plantations are overrun by hérbivorous animals, but by pigs in especial, to the great detriment of the crops. Finally, some of the native princes, and even some of the regents, reserve for themselves the trophies of tiger-or leopard-hunting, in order to keep them in their menageries, or to preserve them for the wild- 
beast fights with which they still, though less often than of old, enliven their principal feasts or receptions.

The larger animals are hunted most of all in the Preangers, where they are most plentiful and most dangerous. The natives try to take them alive in heavy traps, the principle of which is very much that of a rat-trap; in this way some of the finest tigers find their way to the special quarters in the palaces of the Sultan of Djokjakarta or the Susuhunan of Surakarta, where they are kept in reserve for some future festival; but the greater number are drowned in their traps, which are carried to the nearest river, in order that the beasts may be killed without damage to their skins. Tigers are also taken by many other means.

For every tiger killed the hunter receives a Government bounty; and the skin, deprived of its teeth, claws, and whiskers, which the native regards as a very powerful fetish, and one for which he will pay a considerable price, is also sold on the spot for a very fair price. Some skins are sent to Europe; but the greater number remain in the Archipelago, where they are employed in the making of rugs and saddlery and for decorative purposes; unfortunately the process by which they are tanned is usually so unsuccessful that, under the influence of insects and the damp, such articles quickly lose their lustre and their value.

Although there are no wild elephants in Java, there are herds of rhinoceros, which gradually decrease as the uncultivated tracts of the island are reclaimed. The Javanese kill them all the more willingly because the hide of a rhinoceros will often fetch more than 200 florins (over $f \mathrm{I} 6$ ) on the spot. The natives eat the flesh, and the horns are sold at a high price to the Chinese, who believe them to possess remarkable medicinal and restorative qualities. The Javanese themselves believe that a little disc of rhinoceros horn applied to a serpent's bite will neutralise the venom; the hide serves to make whips and switches; while 
the Chinese sometimes carve the horns, mount them on a base, and send them to Europe. The Javanese, in order to avoid injuring the hide, always prefer to snare the rhinoceros rather than shoot it.

The wild pig abounds in Java. The principal species are, the widjung, or "coffee-pig" (Sus vittatus), whose flesh is excellent eating, and the gonteng of the mountains, called wraha in the plains, or "callous swine" (Sus verrucosus), which is far less highly appreciated. In order to protect their crops, and on account of its ferocity, the Javanese hunt the pig relentlessly; they do not, however, gain much by the sport, as their religion forbids them to eat the flesh of swine, which is accordingly left to the Chinese. In some of the mountain regions, however, this law is less strictly observed, and the dried flesh, cut into thin slices, and sold under the name of dendeng, ${ }^{\mathbf{I}}$ finds plenty of consumers who do not boggle over its origin. The great wild buffalo, or banteng (Bos sondaicus), which is shot and eaten on the spot, is a profitable quarry, as its hide, horns, and hooves are employed in the manufacture of a large number of articles for every-day use or for exportation.

Deer (rusa) are almost as plentiful as wild pigs, and are hunted even more eagerly. The dried venison, or dendeng, is a staple article of commerce in the Archipelago; the horns and hide are utilised in various industries. The young antlers, still covered with a mossy skin, are also bought at a fair price by the Chinese, who regard their fortifying virtues to be even superior to those of the rhinoceros horn. The dried tendons are also secured for the tables of the wealthy, and are even exported to China; they are used in the manufacture of a succulent sweetmeat.

Stag-hunting, whether undertaken with the rifle or with hounds, is a passion which the Europeans share with the natives. The result is a gradual but percep-

* All dried meat, whether seasoned with spices or not, is called dendeng in Java. 
tible decrease in the numbers of the deer, which one no longer sees, as the great naturalist Junghuhn saw them on the Iyen in I860, in herds to the number of many thousands. The roe deer, which are very abundant, are valued especially for their flesh.

Among the cetaceans the sea-cow or dugong, duyong (Halicore Dujong), is eaten with enjoyment by the natives, $x$ who also hunt the cachalot (ikan lodan), principally for its teeth, which are made into kreeshandles. Both these mammalia are more common in the Outer Possessions than about Java.

Many Javanese birds are greatly prized, either for their plumage or for their flesh. The peacock is eaten, as is the wildfowl, the duck, the plover, the woodcock (which at certain periods is very abundant in the western part of the island, and is taken alive), the dlimangan or tre, a quail, which is sometimes trained to fight, and also doves and pigeons, which are greatly esteemed both for their flesh and their song, and are found in almost every Javanese dwelling, where their soothing voices break the midday silence.

Certain pigeons, parakeets, cockatoos, kingfishers, doves, sri-gunting (Edolius fortificatus), and birds of paradise are caught by the net or by liming, instead of being shot, as their plumage is the object of an important export trade with China and Europe.

As for snakes, the Javanese eat their flesh, but have hitherto made little use of their skins. Now, however, a demand is springing up in Europe for the latter, which are used in the fabrication of purses, card-cases, pocket-books, \&c.

All things being considered, however, the native gains more by his fisheries than by hunting. Fish literally swarm in the Javanese seas and rivers, and of the hundreds of species caught there are very few that are not of use for edible or other purposes.

The king of the fresh-water fish is the gurami (Ospho-

× Syn. Dugong, perampuwan laut (in Malay, sea-woman, mermaid). 
menus olfax), which is reserved for the tables of chiefs or the wealthy, and is reared for the market in special fish-ponds or tanks. A gurami of 20 to 30 pounds' weight is always a welcome present in the Dutch Indies. Natives, Europeans, and Chinese all appreciate it equally; but Europeans prefer to eat it while quite young, and weighing only 3 pounds, or less. It reminds one of a perch, and belongs to the same family, but has a more distinct flavour. Among the anabas we must mention the betek, or climbing perch, which is able, thanks to a peculiar cellular structure, to leave the water for short periods of time, when it climbs up the roots of the trees growing in the marshes, and there obtains a plentiful harvest of insects. Then there is the gabus, an article of the greatest importance throughout all Java, where it is consumed more especially as ikan kring-that is, in the dried state-while the Dutch prefer to eat it newly caught; the bayong, which is rather less fat than the gabas, and which seldom attains a weight of more than $4 \frac{1}{2}$ pounds. It is very abundant and is also eaten in the dried state. Many varieties of carp are carefully reared in enormous fish-ponds for sale to the Dutch and the Chinese; one species, the tambra, is reared especially for the Chinese and the natives. There are also various species of eels and conger; marsh lampreys, which are reared for the tables of the Europeans; numbers of mud-fish (silures) which seem to issue from the earth when the ricefields are inundated, so plentiful are they, and which the natives obtain for next to nothing, even in the markets. These fish are all nourishing and of an excellent flavour.

The sea-fisheries are naturally undertaken by the seaboard populations. The most valued of all the saltwater fish, though not the most abundant, is the kakap; next comes the roto, which is far less readily caught. There are various kinds of mackerel, including the tunny, which is eaten either fresh or preserved; still more 
numerous varieties of the herring, the best of which is the bandeng; and finally the trubuk, the Indian or longtailed shad, which is caught chiefly off the eastern coast of Sumatra, but which is also found on the Javanese coast; the salted roe of which is a condiment highly valued, even by some Europeans.

The necessity of overcoming the monotony of perpetual rice and facilitating its digestion, and the natives' custom of eating a certain amount of their meat and most of their fish in a smoked, dried, or salted condition, explains the common use in Java, as in nearly all countries of the Far East, of those animal and vegetable condiments whose ingredients and odour are nearly always so violently repugnant to the European.

The condiments most usually employed in Java among the better class of natives are : ikan gerek, a paste made of various small fishes, kneaded up with salt, "Spanish pepper," I and various spices, which is packed in baskets, in which it gradually becomes of a firmer consistency; trassi, or terasi, a paste of prawns, shrimps, or small fishes, brayed together with salt and spices; $e b b i$, or dried prawns and river crayfish, which are exported as far as China. To these complementary aliments the Javanese are fond of adding the salted eggs of the duck, hen, or turtle (telor asin), and the shad's roe, or trubuk. As for trepang, or bêche de mer ${ }^{2}$ (the holothure, or seacucumber), which crawls in enormous numbers along the sea-bottoms of Java, the natives eagerly carry on this fishery, but as a means of making money, for they do not

- Dutch : Spaansche peper. This is the Capsicum annuum L., or annual pepper, better known in France as Indian pepper, or long pepper.

" Or beech-de-mer, from the Portuguese bicho-de-mar, "sea-worm," or sea-slug; the zee-komkommer, or sea-cucumber of the Dutch. The price per picul (a weight of $133 \mathrm{lb}$.) varies from 2 florins 50 to I70 florins, according to the locality and the quality. In China, the great market for this merchandise, the price runs from 50 to 275 florins, and the picul contains from 1,000 to 2,000 sea-slugs. The Dutch Indies produce and export to China about 700 tons per annum. 


\section{THE NATIVES OF JAVA}

eat them any more than do the Europeans. Boiled, salted, and then dried or smoked, they are exported to China, where they fetch a high price. Thousands of the seaboard Javanese live by the trepang fishery alone.

The shell of the turtle (Chelonia imbricata) is almost entirely exported to Europe and to China; but the shell of the common tortoise (tutrugu) is often sent to Surabaja, where it is made into combs, boxes, spoons, \&c.

To the abundant natural resources of his island the Javanese may add the industry of stock-raising. It is true that his lack of care and foresight has limited the numbers of his flocks and herds and has failed to improve the breeds of his domestic animals.

The most useful beast of all from the native's point of view is the kerbau (Malay), or kebo (Javanese); the buffalo, so powerful yet so gentle, which drags the heaviest burdens with a sure foot over the miry roads or the stony mountain trails; the buffalo, which shares his labours; the buffalo whose meat, if a little musky, is excellent whether fresh or salted. The native prefers the buffalo above all the domestic animals; the bullock (sapi, or lembu), less vigorous but more active, is still better as a draught animal on a good road, and its meat is far sweeter; the cow is regarded purely as a reproductive animal, as the Javanese dislikes milk and its various products; the goat and the sheep are kept more for the sake of their meat than for any any other purpose ; and pigs are fed only for sale to the Chinese.

The horse (kuda in Malay, dyaran or kapal in Javanese) is a favourite animal, but is not methodically bred or cared for, and has consequently degenerated. Formerly it was used solely as a saddle- or pack-horse. The Europeans have taught the Javanese the art of breaking it to go in harness and to draw burdens, but in order to preserve the species have forbidden them to kill it for the sake of its flesh. The horses of Preanger, which have an obvious Arab strain, are the tallest in the island and are well proportioned, but otherwise cannot be highly praised. Those of Kedu, which have been improved by 
the care of the Susuhunans, are their rivals in height and are still better proportioned; but the ordinary Javanese horse of the sawahs (rice-fields) or the mountains is small and ugly, but sure-footed and enduring. It is certain that if the Javanese native would refrain from working his horse too young, and would feed it in a rational manner, he would be able to improve the race and derive from it incalculable benefits.

\section{VI.}

Just as the Javanese, despite his love of the soil, prefers to cultivate only so much of it as will satisfy his daily needs, so his industry also is limited to his requirements. Each village has its blacksmith, its carpenter, and very often its potter and silversmith. The trade guilds in the towns may contain a certain number of workers in each trade, but they will be careful to produce only enough to supply the usual demand, and will work only according to tradition. It is no lack of taste nor of ability that keeps them to these beaten tracks; their chiselled and sculptured gold and silver work is often excellent, and the women who work at the looms are real artists. The two industries which are peculiar to the Javanese, and in which their originality is most plainly shown, are the manufacture of the krees, I the value of which depends

I The kriss, or krees, is the characteristic arm of the Malay races. It must not be confounded with the other forms of sword or dagger used in the Archipelago. There are more than a hundred kinds of krees, each bearing a different name according to the shape of the blade, guard, and scabbard. The blade, which is commonly i2 to 16 inches in length and always flat, is straight or serpentine in form, and is usually damascened with pamor, a magnetic iron which comes from Luwu (south of Celebes): this treatment gives the blade a moiré, or watered, surface. The grip, or hilt, made of wood, horn, ivory, or metal, assumes the most fantastic forms ; in the case of a prince's or wealthy noble's krees it will be ornamented with precious stones. The scabbard is of wood and covered with a sheath of survasa (bronze), silver, or gold. The krees is not merely an arm, but a symbol of rank and authority as well, as the sword 
upon the temper of the weapon and the material and carving of the handle, and the ornamentation of stuffs by the batik or battek process. The art of plaiting and weaving and staining mats of every size and shape and intended for all manners of purposes is also a widespread Javanese industry; but it is not peculiarly Javanese, being common to most peoples of the Far East, while kreesses and batiks $\mathrm{x}$ in cloth coloured through a mask or ground of wax are exclusively Javanese industries.

To batik signifies to cover a cotton fabric with a thin ground of wax before plunging it into a bath of dye, so as to preserve from the latter certain parts of the stuff, thus forming a design. This operation, repeated several times in succession, but with a dye of different colour on each occasion and with the stuff re-coated so as to preserve different portions from the dye, finally produces a design which is often of real artistic value. The batikmaker-and this delicate work is always done by women -is provided with a tyanting, or a little cup or funnel of the thinnest sheet-copper, which is filled with white wax in a melted condition. This wax she allows to trickle very slowly through a slender tube, as fine as the point of a pen at its lower extremity. With the aid of this little instrument-which roughly resembles the funnels used for the sugar icing on wedding-cakes-the batiqueuse draws her design on the cotton fabric in a line of warm and liquid wax; the width of the line being varied by

was in Europe during the Middle Ages, and was in Japan within living memory. It is worn in various manners, which are regulated by etiquette. For further details see the article Wapens der inlandsche Bevolking (Encycl. v. Ned.-Indië, vol. iv. p. 686 et seq.).

- The Javanese word batik, "to design, trace, paint," has assumed the technical meaning "to draw upon a cotton cloth with molten wax." It is an ingenious process, by means of which coloured stuffs of many colours and a remarkable variety of designs are produced. The following work, illustrated with coloured plates representing some of the finest specimens, includes all possible information as to the batik industry in Java: G. P. Rouffaer and Dr. H. H. Juynboll, De batik-kunst in Nederlandsch-Indië en haar gescheidenis (Haarlem, 1900-1905, large 4to). 
using a tyanting with a larger or smaller vent. When the worker has traced the design in wax upon one face of the cloth, she reproduces it by the same means upon the other face, so that the stuff has no "wrong side" and may be used with either side uppermost. The piece of cotton with its design in wax is now plunged into a vat containing a dye of suitable shade-usually a red, blue, or brown-which dyes all portions that are not covered by the waxen design. The wax is removed by means of boiling water; and before plunging the cloth into a second vat containing dye of a different shade the design is continued by means of a fresh application of wax in all the necessary parts. By repeated applications of wax and repeated immersions in various dyes it is possible to obtain extremely complex designs, which possess a charm all their own and are gay and harmonious in colour. ${ }^{x}$

The batik process entails a traditional technical education and considerable taste on the part of the craftswoman. There are hundreds of accepted batik designs, certain of which are reserved for certain articles of clothing or even for certain persons. The Susuhunan and the Sultan of the Vorstenlanden wear batiks of special design that no other native would dare to wear, at any rate in the Vorstenlanden themselves. Moreover, Surakarta and Djokjakarta boast of what we may justifiably call schools of design and colouring, and their batiks compel the admiration of the best foreign connoisseurs. Samarang, although its batiks are rather more gaudy, still maintains the high reputation of its women artists, who elsewhere, and especially in Batavia, are now allowing themselves to be influenced by European taste, or rather by European commercial

- The Dravidians of the Coromandel coast (Tamils, Telingas, \&c.) also prepare cloths of polychromatic design by the same procedure, a very faithful and detailed description of which has been preserved in the Letter of Père Coeurdoux, missionary of the Company of Jesus, to Père du Halde, of the same Company, January 18,1742 (Lettres édifiantes et curieuses, t. xxvi., Paris, 1743, p. 172 et seq.). 
designs, which do not in the least represent the art of Europe, and are losing their originality. One of the causes of this decadence has been the introduction of printed calicoes with which the European houses have flooded the markets of Java. The natives, tempted by their low prices, have bought them, and have immediately set to work to imitate them, and by employing the simplest means they produce imitations equal to the European goods, but at a still lower price. The merchants, in consequence, have gained nothing by the transaction, but the delicate art of the batik has greatly suffered by the introduction of this rubbish. Already Cheribon and Indramaju have practically ceased to produce the batiks for which they were formerly so renowned, and which used to sell for as much as $£ 4$ the piece; indeed, unless something is done to arrest the decadence of the process, these examples of a charming and consummate art will in fifty or sixty years' time be found only in the kratons of the princes and the cabinets of European collectors.

The Javanese batik their cotton stuffs on one or both sides only for the very practical purpose of beautifying their garments. Their costume is simple, and is the same for both sexes, a fact which at first leaves the foreigner subject to awkward misunderstandings. The basis of the costume, indeed sometimes the whole costume, is the sarong; that is, a kind of skirt falling from the waist, or sometimes above it, to the feet. When open in front it is called the kain pandjang. Sarongs and skirts worn by the people are often of a deep blue colour; among the rich, in the east and centre of the island, the stuff is batik'd; in the west it is often checkered or striped, the checks or stripes being woven in the stuff. Checks are common among the Sundanese. To the sarong, the man adds a sort of vest of white cotton (kutungan) or coloured cotton print, or a kind of short jacket of white cotton or print, with wide sleeves and a standing collar, fastened at the throat and loose on the hips. Native officials replace this by a cloth or cotton 
jacket with narrow sleeves, fastened up with buttons ornamented with a $\mathrm{W}$ and a crown.

The man's long hair is done up in a chignon on the top of the head, and hidden by a kerchief, more or less artistically $b a t i k^{\prime} d$, the corners of which emerge like two wings on either side of the nape. As a defence against the sun or rain, the native often wears a wide hat of bamboo fibre or plaited pandanus leaf, either plain or in several bright colours. This hat may be more than a yard in diameter, when it forms an excellent substitute for an umbrella or parasol. Native dandies and officials replace this hat, in the towns, by a peaked cap, which is ornamented, in the case of the officials, by the W surmounted by a crown.

The official headgear for state occasions is a kind of fez : a truncated cone, called a kuluk, covered with transparent starched muslin. In the case of princes the kuluk is ornamented with vertical stripes of gold, and is known as the kanigara. A krees, passed through the girdle and carried behind the left haunch, completes the toilet of every Javanese freeman. The krees, which the Madurese, and still more the Malay, will draw at the first word that he chooses to think insulting, is for the Javanese, as we have seen, primarily an ornament.

Personages of high rank are always accompanied by a parasol (payong), their rank being denoted by its height, colour, and wealth of gold. Priests and Hadjis commonly wear the Arab costume, and thereby gain no little consideration; but some Javanese wear it who have never been to Mecca.

Women add to the sarong a wide bandage, of blue cloth upon ordinary occasions, but in batik on feast days. This is called the kemben, and is wound round the bust, under the arms, so as to flatten the breasts, a full bosom being unappreciated by the Javanese. Some women also wear the kutang, a kind of bodice or tunic, and still more frequently the kelambi, a kind of camisole, in dark blue cotton, black silk, or velvet of some dark shade, which is cut low at the neck. It falls to the knees, and the 
narrow sleeves are closed with strings. An indispensable article of the feminine toilet is the slendang: a scarf in batik, often ornamented with fringes; something over 20 inches wide, in colour brown, green, or yellow, or, among the poorer classes, a deep blue. It is sometimes made of silk, sometimes of cotton, and serves for all kinds of purposes. The well-dressed woman wears it simply as an ornament; the women of the people wear it across one shoulder, like a bandolier, and use it for carrying the last-born baby, the goods they have bought or are going to sell, and so on.

The Javanese woman is always bareheaded in the presence of the Javanese man; but she decks her hair with freshly plucked flowers or ornamental pins. Like the women of all countries, she loves necklaces, rings, and bracelets of all kinds, and heavy earrings of a peculiar type, which stretch the lobe of the ear to a mere thread. She shelters herself from the rain beneath an umbrella of oiled paper.

Men and women go barefoot, including the native soldiers of the colonial army, excepting only the Amboinese. $x$

A few exquisites wear slippers or shoes of European model, and their use is becoming more and more general among the more distinguished natives, although all natives must appear barefooted at the courts of the Susuhunan and the Sultan; and before such native notables as the regents, \&c., all inferiors must appear with bare feet.

\section{VII.}

Although the life of a Javanese village is never intensely laborious it is, in a sense, a life of continuous labour; for the Javanese does not feel compelled to abstain from labour entirely upon any day of the week-not even on a Friday-to satisfy his religious beliefs. He works as

- This is partly because so many of the Amboinese are Christians, and partly because they pretend to give their services in Netherlands India as allies, not as subjects; as equals, not as a conquered race. 
long as he needs to work ; but only too often only just so long. Neither is his labour a melancholy affair ; for the severer agricultural tasks, such as the transplanting or harvesting the rice, are performed in common; all the people of the dessa help one another, and enjoy a banquet at the end of all. Again, all the villagers share in the same pleasures ; no feast, marriage, or circumcision takes place without the presence of the whole village, or at least the majority of the inhabitants.

These holidays are numerous, precisely because the Javanese is not fanatically fond of work. But they are not uproarious; the traveller is always surprised to witness the heartfelt gaiety-a gaiety without shouting and screaming, without guffaws and shrieks of laughterof this gentle and polished people. They are as quiet in their gaiety or their anger as the birds of their country, whose plumage is so beautiful, but which are almost songless.

The people crowd through the bazaar or upon the aloun-aloun, but with a gentle, noiseless movement; their inner satisfaction is only betrayed by the fact that their clothing is more ornamental than usual and their faces brighter.

If Korea is entitled the Empire of the Quiet Morning, Java deserves the name of the Island of Silent Serenity.

Among the habitual pleasures of the Javanese, tobacco (roko) and the betel-nut (sirih) have passed into the rank of necessities, so general is the use of these two stimulants, and particularly that of the latter. Betel is used by women as much as by men, and both use it continually. From the poorest coolie to the Susuhunan, every Javanese is always chewing this refreshing condiment, which blackens the teeth, however, and provokes an abundant flow of reddened saliva. At all domestic rejoicings the sirih is offered to all the guests; and the accessories necessary to betel-chewing accompany the great wherever they go.

The use of opium, which is by no means so harmless, has, unfortunately, been becoming more and more usual during the last twenty years. For this reason all those 


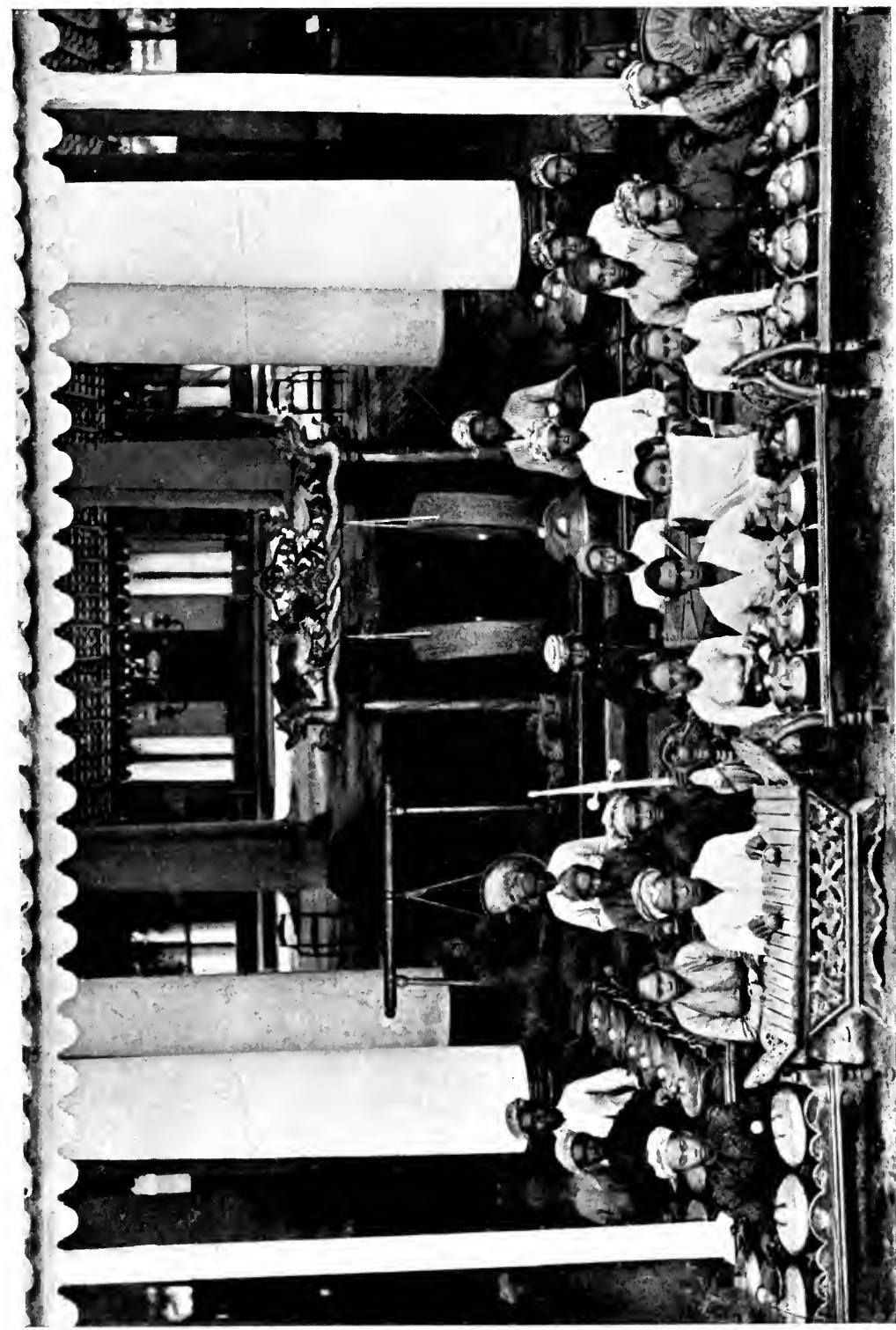


who concern themselves with the welfare of the natives are anxious that the Chinese should be forced to abandon the growth of the poppy in order to restrain the abuse of the drug.

Dice, cards, quail- and cock-fights, ${ }^{2}$ and tops with numbered sides, on the stoppage of which bets are laid, are still favourite means of amusement with the Javanese native, who will sometimes, in the excitement of play, ruin himself within a few hours. We must not be surprised to find such amusements severely proscribed by the better classes of the natives, who are to-day so anxious to bring about a popular renascence; but it will certainly be no easy task to wean the people from such amusements, as the native of almost every quarter of the Far East has a regrettable passion for games of chance.

On the other hand, the Javanese of the people, more on account of his natural sobriety than out of religious scruple, is not addicted to fermented and alcoholic drinks; he leaves them to the mighty and to the princes of his race, who, despite the precepts of the Koran, are not reluctant to imitate the European in this particular.

Performances on the gamelan 3 and the representations of the wayang are the favourite amusements of the people, and on special occasions their chiefs and princes entertain them by means of their own troupes.

- Concerning opium and its use in the Dutch Indies, see $\mathrm{E}$. Metzger, Das Opium in Indonesien (Rev. Col. intern. 1887, II., p. I75) ; J. L. Zegers, Het opium-vraagstuk in Nederlandsch OostIndië (Nimeguen, 1890).

$=$ Officially prohibited in certain Residencies, they none the less continue in secret.

3 The full gamelan appears to be a development of the xylophone. As we gather from M. Caboton's description, the basis of the gamelan is the ordinary xylophone; in the full gamelan the note is produced by one of a series of blades, tubes, gongs, or basins. The illustration facing p. 127 shows a series of "xylophones" of different materials ; some having wooden notes, some slips of metal, some a series of tubes bedded in cushions, and some a series of bronze vessels not unlike square tureens. The word gamelan means sometimes a single "xylophone," sometimes a whole orchestra of "xylophones" of various materials, including gongs, suspended tubes, a viol, \&c.-[TRANs.] 
The gamelan is a complete orchestra composed of an oblong plank of wood, supported on four legs, and with raised edges. Across this plank, and resting upon little cushions, are fixed a series of blades or slips of varying lengths; one set will be of wood, another of copper, others of bronze; some will have affixed to them vertical tubes of bamboo, which serve as resonators. Each blade or slip gives out, when struck, a note consecutive to that produced by its neighbour. The gamelan may also include a series of bronze basins, some wide and shallow, others deep and narrow; or these may be replaced by suspended gongs. A viol with two strings and a bow, known as the rebab, is used to play the air when the gamelan accompanies the voice. All the instruments of the gamelan, which are struck by hammers of different materials, according to the tonality desired, and according to a very abstruse technique, produce a shrill and somewhat melancholy music, which is at first surprising to a foreign ear, but which is by no means without a charm of its own.x

At domestic gatherings in the villages the natives have usually to content themselves with the rebab (or viol), the flute, or with drums of various size, shape, and tone ; but when a chief entertains those under his administration at a wayang show, accompanied by the gamelan, the Javanese native passes a delightful evening; but the entertainment, to be precise, often lasts far into the night.

× Other instruments which may be included in the gamelan are: angklung, or "sonorous tubular gongs, suspended in a framework," bonang, "a peal of bells," tjelempung, "a psalterion," ketuk, kenong, "bells"; saron, " a series of metallic tongues or blades"; demung, "the same, but deeper in tone"; gong, " a thick bamboo tube which is struck to obtain the bass note" ; kempul, " a little gong" ; kendang, "a drum, the two heads of which are of unequal diameters." Land, Notes sur la musique dé l'île de fava, says that this music "is a subject well worth the serious interest of the musician." See also E. Dulaurier, Musique Favanaise. Notice sur un gamelan ou collection d'instruments de musique javanaise, rapportée de l'île de Fava à Paris, en 1845 , in the Revue de l'Orient, de l'Algérie et des Colonies, I7th year (Paris and Algiers, 1859). 
The wayang is a puppet-show, a theatre of marionettes. The puppets are perfectly flat, with movable arms; their faces and limbs are fantastically deformed-in order, say the Javanese, to evade the Musulman law, which forbids the reproduction of the human body. They are sometimes made of buffalo hide, sometimes of wood, brightly painted and gilded, and often luxuriously dressed; they are manipulated behind a screen upon which the light of a copper lantern throws their shadows. The women watch the drama from in front of the screen, the men from behind it, according to the position of the marionettes themselves.

There are three kinds of wayang, which are not very clearly distinguished; and a different tonality of the gamelan is appropriate to each. An actor recites the poem or drama which the marionettes perform, interrupting it considerably by long personal improvisations. In the best representations the subject is always borrowed from the Hindu epics of the Mahabharata and the Ramayana, with the alterations and distortions for which the Javanese mind has been responsible during the centuries which have passed since the extinction of the Hindu faith ; or from the heroic and legendary history of Java before the foundation of the Empire of Madjapahit-that is, before the ninth century A.D.; or sometimes, but more rarely, from the history of the aforesaid Empire. This choice shows how deeply the Hindu domination has impressed the Javanese mind. The part played by Islam in this dramatic literature is inconsiderable, and is usually limited to the confiscation of the miracles performed by the demi-gods of India to the profit of Allah; and occasionally, especially during the last twelve years, the dalan, or reciter, improvises, between two lines of some traditional poem, some malicious reflection upon his European masters.

When the wayang is not available, the Javanese turns cheerfully to the topeng dalang, in which masked actors play in pantomime a drama which the dalan recites in a loud voice; or sometimes the actors themselves 
speak, and give their performances in the open, surrounded by a circle of auditors who hang upon their every word. They enjoy almost as naively the dances of the ronggengs-public dancing-girls-whose methods always astonish and disappoint the uninstructed European; for the Javanese dance consists of a series of plastic and mimetic poses, which require, even more than Javanese music, a previous initiation on the part of a foreigner. Even at the bedayas of the sovereigns of the Vorstenlanden and a few of the regents, who preserve the implacable traditions of the classic dance, the foreigner is usually less pleased than astonished.

Wayangs, gamelans, dancers, and distributions of food and of betel form the regular programme of the fêtes which the notables and the wealthy offer to the people on occasions which are as varied as they are numerous. The birthdays of the Queen-Mother and the Queen of Holland, and that of the little Princess Juliana, give the highly placed Javanese an opportunity of testifying his loyalty and of giving pleasure to the people. Other occasions for such festivals are : his appointment to any post under the Government; his marriage; the birth of his children ; the circumcision of his boys ; the declaration of the nubility of his daughters; the marriage of a son or a daughter ; the filing of his teeth ; the conclusion of a lucky business affair; the recovery from an illness; the return from a journey; the rice harvest; the building of a house ; in short, the Javanese has a genius for discovering such occasions; he finds them in the most trifling details of his life, and celebrates them with enthusiasm. On every step of the social ladder the Javanese rejoices at the festivals of his superiors : very often at those of his inferiors, when he wishes to honour the latter. The result is that although there are very few actual religious holidays, the Javanese is continually junketing; a course which keeps him from his work, and is often absolutely ruinous.

Very probably nearly all these festivals are of remote origin, some arising out of the Islamite code of manners ; 
adapted indifferently, they allow one to guess at a surviving basis in the ancient animistic cult of Java. They open with prayers recited by the imaum of the village, or in his absence by some person distinguished for his piety; and one may suppose that their generic name of slamettans, or thanksgiving feasts, sanctifies the banquet which is the necessary accompaniment of the feast, and often its object. Adat (custom) has fixed the number, nature, quantity, and preparation of the sacrificial dishes, of which the spirits enjoy the subtile and the sacrificers the material portion. In the courts of the princes the religious character of the sacrificial repast offered to the spirits is accentuated by the care taken to reserve a portion of the dishes for the priests and santris (holy men).

Generally the giver of a slamettan bears the whole cost; but often he cannot afford to do so, when he will arrange with several friends to give the feast at their common expense. Each one performs his share by bringing one of the required courses, and the sacrificial feast becomes something like a picnic. The gamelan and the wayang which nearly always terminate the feast add to the joyful impression produced by the whole.

We can understand why Javanese reformers are so anxious to put down the constant succession of slamettans, which empty the native's slender purse, and accustom him to idleness and imprudence.

\section{VIII.}

The Europeans, who in all their colonies are very loth to allow the natives any virtues, do not fail to criticise many other points of the Javanese character.

Some reproach him roundly for his gentle manners, which to them seem to border upon cowardice; for his incurable apathy and lack of foresight; for his faintly servile and hypocritical politeness, his absurd veneration of birth, his immoderate appetite for honours; for the fact that the only motive capable of awaking him out of his lethargy is the hope of realising that secret ambition 
of every Javanese : to become an official and to win the right to a payong (a State umbrella) of respectable diameter.

Perhaps there is hardly one of these grievances which the history of Java does not justify.

It would be surprising if the Javanese were instinctively a coward. All his past history is full of interminable wars, a fact which at all events denotes a certain military aptitude; doubtless accompanied, at the end of ages of butchery, by a fatigued philosophy. The race which won the military glory of the conquering empires of Madjapahit and Mataram, and which sustained the desperate war against the Dutch which lasted from I825 until r830, having at its head such leaders as Dipo Negoro and the young and heroic Sentot, is hardly a nation of the peace-at-any-price variety; and its men are not of a spirit that will fly at the least threat. Those who know the race well know the danger of exasperating its apparently placid nature. The Javanese has retained, through his warlike and tumultuous past, those qualities of a good soldier which make him an invaluable recruit for the Dutch Colonial army. He is brave somewhat as the ancient Greek was brave, who would rush upon the enemy with heroic courage when he saw that victory was possible, but who would fly without shame from an enemy obviously too powerful. He has no uncontrollable love of danger; perhaps because he saw long ago that his life was too readily sacrificed by others; but his sense of discipline rarely allows him to abandon a post, however dangerous. As for his fearing "my Lord the Tiger"as all the natives of the Far East fear him-and attempting to flatter him by soft words and courteous phrases, the matter is easily comprehensible in a country in which the tiger's victims are counted by hundreds year after year. The Javanese feels himself naked and defenceless before so formidable an enemy, and is afraid; the European, of a different mettle, armed with a heavy rifle, should certainly encounter the tiger with a better countenance. It is, perhaps, hardly fair to speak of the cowardice of the 


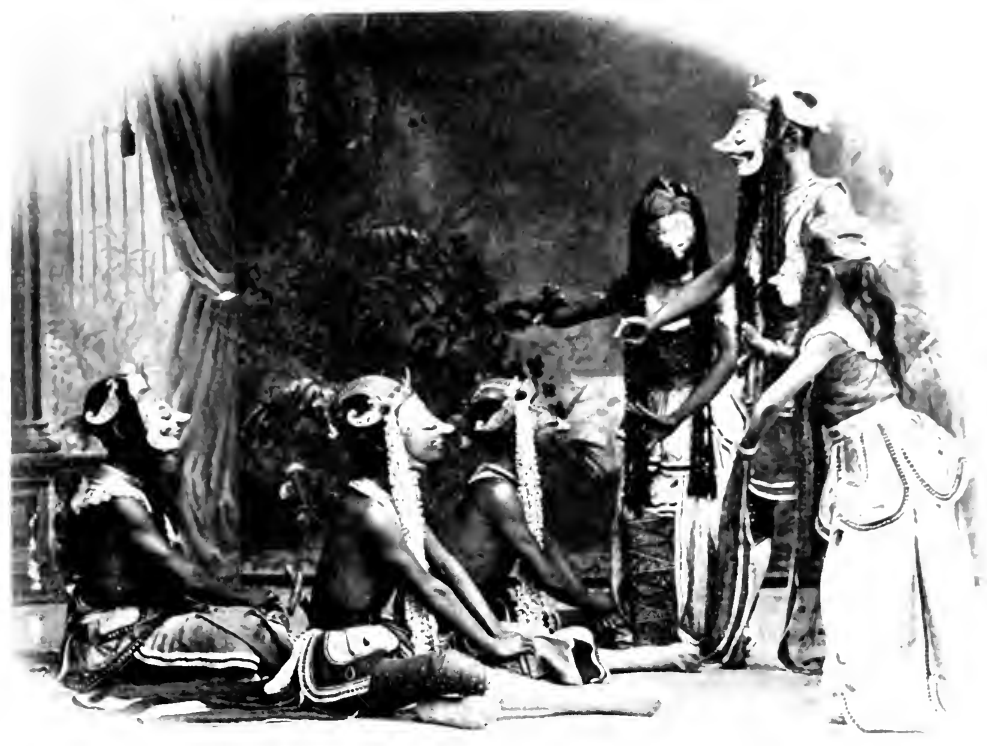

A "WAYANG" : JAVANESE PLAYERS.

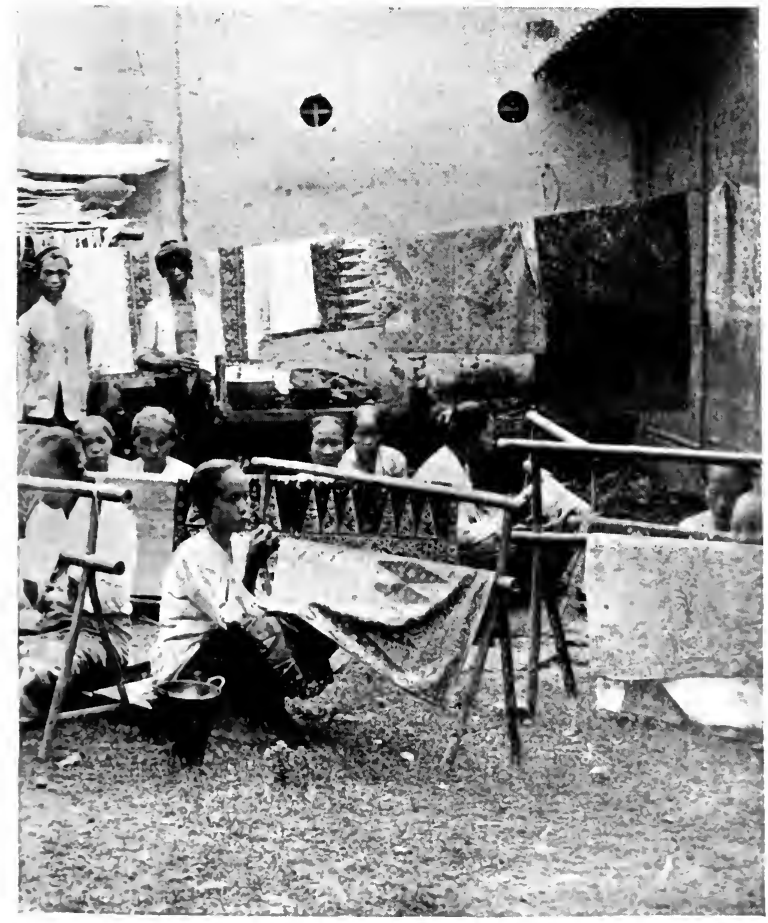



one or the courage of the other; to do so would be to ignore the circumstances.

The regrettable lack of foresight of the Javanese is less deniable. The Javanese is incapable of taking care for the morrow, of saving for the lean days, or of economising. $\mathrm{He}$ will, as likely as not, spend the savings of a month or a year in the course of a few hours ; and in order to play at dice, or give a ceremonial banquet, he will borrow money at the most usurious interest, and is seldom able to resist the offers of goods on credit which the Chinese and Arab are so generous in making him. But we must remember that the Javanese native was exploited for centuries by all his rulers; that he has had to work for them unremittingly; that he could call nothing but his life his own; and we must not forget that slavery was officially abolished only as lately as I86o. Such a record of poverty would hardly teach the race economy, even admitting that economy were possible. The native knew that he could never save for his own benefit, and hence the habit of never saving at all. But why should a man save when he can live on a handful of rice and a few bananas? However, since prolonged contact with the Dutch has revealed new sources of pleasure and new necessities, and since the Dutch Government has been occupying itself seriously in bettering the lot of the native, and not merely the yield of the soil, the Javanese is beginning to meditate upon the question of saving, if only to enjoy himself the better on special occasions. Reputed idle and apathetic, although he works under a fiery sky, and often under deadly conditions, he will nowadays travel long distances the moment he hears of an offer of good wages. Even from the central provinces he will set out at the time of the rice or sugar-cane harvest, often travelling as far as the eastern side of the Peninsula, on to Malang, or even to Surabaja and Samarang; in short, wherever he can earn 3 to 5 francs a day (2s. 5d. to 4s.). The few savings-banks already opened with a view to develop the prosperity of the natives were at first regarded with a certain amount of sus- 
picion, but lately the deposits have been larger each year.

It is hardly possible as yet to expect democratic ideas or a passionate love of independence from a race formed first by the Hindus and their oppressive caste system, and then by Islam with its fundamental fatalism : a race which for twenty centuries has been governed by greedy autocrats or disdainful masters. For this fact the Dutch may well be thankful ; for if, in addition to their numerical strength, the Javanese had possessed the indomitable temper of the Achinese, no European Power could ever have settled in the island. Gentle and patient by nature, the Javanese have been crushed and enslaved during the whole of their long history; but it would be unjust to call them servile or hypocritical or cowardly, because they treat their masters to-day with the marks of deference which they showed their masters of long ago ; a deference which does not signify the servility which some profess to behold in it, but merely a venerable tradition of politeness. It is as well to note that those who complain the most of the factitious quality of Javanese politeness would be the first to complain were it lacking towards themselves. They would regard such a lack as an insult, almost as a crime.

On the other hand, nothing amazes them so much as the smouldering rancour which insulting words or behaviour will evoke in the hearts of such people, for whom good manners and the distinction of classes are still the foundation of the social system, and who, having done what they conceive their duty by the Europeans in treating them with every shade of intentional courtesy, do not receive in return the consideration which they consider their due.

Their avid appetite for honours and outward distinctions, their hunger for umbrellas (payongs) and promotion in the grades of official hierarchy, is explicable in the light of their past, for they have always been accustomed to see these signs accompanied by the reality and enjoyment of power, with all its abuses. We must recognise, 
moreover, that the present has been so far unable to accomplish very much in the way of modifying the conception inherited from the autocracies of the past, and from the traditions of Hinduism and Islam. The Javanese issues from his lethargy and progresses in culture and initiative only when self-interest draws him. This is a regrettable fact: but it is also true of the majority of Europeans, whose conceptions, from different motives, are becoming more and more utilitarian, while purely disinterested culture is becoming rare.

The Javanese does not even seek to improve his equipment with a view to enriching himself by a praiseworthy commercial activity, or a better application of agricultural methods; he dreams, above all, of becoming an official, of wearing a uniform. This is again regrettable; but this also is a common failing elsewhere than under the tropics. But the day may come, even in the colonies, when, with the same native hierarchy, and at the instance of the rulers who are now so politically careful not to shatter the old Javanese conception, we shall see the farmer or the self-made merchant treated by the public authorities with the same benevolence and consideration as the most indifferent mantri.

As long as officialism continues to offer the double advantages of material security and a satisfied vanity, it is unjust to reproach the Javanese with regarding it as the sole end of his efforts. It would be absurd to blame the Javanese for taking a plain, direct view of his immediate interests, and to expect him, after centuries of veneration of power and authority in its slightest emanations-a veneration encouraged by the Dutch themselves-to awaken suddenly to a radically antithetical conception of rational liberty and individual initiative. He must first receive or give himself a long and difficult education. 


\section{CHAPTER VI}

\section{THE JAVANESE MIND}

I. The religious question in Java is involved in the historic evolution of the masses. The religion of Java is a sincere Islamism, modified by the survivals of earlier cults; tolerant and kindly, like the character of the nation.-II. How the Dutch Indies escaped Christianity.-III. The problem of education in Java; its various phases since the Dutch occupation.-IV. The awakening of the Javanese people and their leaders; their claims.

\section{I.}

IT is difficult to acquire a satisfactory conception of the Javanese mentality unless we allow for the degree of its religious and intellectual development, and for the influence which the Dutch have brought to bear upon both.

The Javanese, like the Sundanese and Madurese, are all, with the exception of a negligible minority, earnest Mahomedans. Their Islamism is sincere rather than fervid, and is modified by the surviving traces of other cults which corresponded to other periods of their past.

Although we cannot say with certainty whence the Javanese originated, nor when they gained possession of their island, it is at least practically certain that they practised, in the first instance, a more or less crude form of animism, doubtless very similar to that which still survives among the Dyaks, Bataks, Alfurs and other races of the Archipelago. $\mathrm{A}$ number of rites and usages

× A very active Christian and Mahomedan propaganda has been carried on for a long time among these peoples, and has succeeded, especially among the Bataks, as the various works published of late years by explorers and missionaries testify. 
borrowed from this ancient cult, and paralleled by the modern animistic cults of the above peoples, persist to this day in Javanese domestic life, in the shape of numberless popular superstitions.

From the first century of the Christian era, according to the most plausible conjectures, down to the thirteenth or fourteenth century, Java and the surrounding islands professed the Hindu or Brahministic faith; and towards the fifth century the Buddhism of the south of India was also introduced. This Hindu civilisation, of which the supreme political expression was to be found in the empires of Tumapel and Madjapahit, while its supreme artistic expression was manifested by Prambanan and Boro-Budur, sets its mark deeply upon the race; even to this day its inspiration is to be found in the social conceptions, the history, the literature, and the theatre of Java; it gave the Javanese his alphabet, and his ancient tongue, or the Kawi; ${ }^{\mathbf{x}}$ and his two forms of customary idiom-the kromo, or High-Javanese, employed in addressing a superior, and the ngoko, or Low-Javanese, employed in speaking with an inferior-are both full of Sanscrit roots.

Towards the thirteenth century probably Islamism was first preached by Persian and Arabian merchants, in the ports of the Far East with which they traded. It slowly made its way into Sumatra, and then into Java. Towards the beginning of the fifteenth century it assumed

3 Kawi-the ancient Javanese language. The kawi or basa kawi (in Sanscrit "the language of the poets") was spoken and written in Java until the fifteenth century, and by process of evolution has become the modern Javanese tongue. Despite its name, the kawi has been as much employed in prose as in poetry, for the translation or imitation of legendary, religious, or juridical Sanscrit works. Raffles made the language known by translating a portion of the Brata-Yuda; Humboldt wrote a study of it in a work, remarkable for its period, entitled Ueber die Karei-Sprache (Berlin, I836-1839, 3 vols. 4 to); but the honour of having explained the true principles of the tongue belongs to Dr. H. Kern (Karoi-Studien, The Hague, I $87 \mathrm{I}, 8 \mathrm{vo}$ ) : a book which has been the starting-point of many learned works on the subject. 
the offensive at Grisei, the first point along the coast to see the formation of a Musulman community around a dynasty of priests-princes. Hinduism vainly offered a desperate resistance. Between 1478 and I52I Madjapahit fell ; the last Brahmins and Buddhists took refuge in Bali and Lombok, and some in the solitudes of Tengger; and all Java became Mahomedan as it had previously become Brahministic and then Buddhistic: without extreme fervour, but with conviction; being persuaded, like many another Asiatic nation, that the best religion was that which was able to triumph over the others. Java is still of the same persuasion; and many a Dutchman now regrets that the Dutch Government did not formerly, in a spirit of simple policy, impress Christianity upon the people.

\section{II.}

One might reply to this that everything shows that at a certain period the thing was possible; the success of the Portuguese propaganda in the Moluccas at that period seems to prove it. Yet the circumstances were far less favourable in the case of Holland; and when the Dutch finally had the leisure to undertake such a task they would probably have found it no longer practicable.

When the Dutch East India Company commenced, at the beginning of the seventeenth century, to eject the Portuguese from the Archipelago, it was composed of men in whom the religious sense was still powerful: men whose very nationality had issued from religious conflict. It could not remain indifferent to the question of conversion, which was still ostensibly one of the objects of its colonial policy. However, instead of attempting to evangelise Java, it applied itself simply to converting the converts of the Portuguese in the Moluccas from Catholicism to Protestantism. Could the Company have done more at that moment, considering the scanty means at its disposal and the enormous area of Java, where it could only obtain foothold little by little, while struggling 
against the sullen jealousy of the Chinese and the quickly awakened hostility of the Mahomedan princes of Java? It is very doubtful. It is probable that the Dutch succeeded in obtaining so complete a foothold in Java only because they put forward no imperialistic policy, no religious designs, but were apparently actuated simply by a utilitarian and commercial object. This wise neutrality, which was imposed by the circumstances, and led to such extraordinary success, became the rule of the Company, so necessary was it to avoid injury to the susceptibilities of the natives, did the Dutch wish, in the first place, to appear their friends and allies, and afterwards, although their rulers, preferable to all other Europeans.

The Dutch were no more able to renounce their policy in 1816 , when they recovered the Indies from the English. In order to counterbalance the happy memories of such an administrator as Sir Stamford Raffles, without adopting his policy, they were obliged to surpass it or to sink it into oblivion by the excellence of their own methods; so that any religious interference at such a time would have been disastrous.

Moreover, in the political system adopted by the Dutch, which was that of governing Java through its chiefs, by means of its own institutions, while they themselves, in spite of their unremitting control, remained in a remote and mysterious twilight which increased their prestige, the separation of the religions and languages of the Europeans and the Javanese became an essential article of their programme.

The Javanese accordingly were not disturbed in their beliefs. When, in the latter half of the eighteenth century, Holland discovered that the intrigues of the Mahomedan Turks and Arabs were likely to cause disturbances in Java, and that her Christian subjects in Amboin were closer to her and perhaps more loyal than the Mahomedan Javanese, and that the pride of Islam was raising a barrier between herself and the natives-a barrier which at that period was no more 
desired by Holland than by the natives themselvesit was already too late to change her religious policy. Both Christian pastors and Catholic priests, the latter being as it were regretfully tolerated in restricted numbers from the beginning of the nineteenth century, were subjected to all kinds of formalities, especially at the outset, before they could obtain permission to make a stay in the Dutch East Indies; were subsidised meagrely or not at all, and were honoured by none of those signs of outward consideration which so greatly impress the natives of the Far East, so that they were necessarily unable to make headway against the absolute indifference of the Javanese.

Was the opinion of the Protestant Raffles correct (which has often been corroborated by various Dutch administrators), that the dry, cold spirituality of Protestantism repelled the natives, who would have been converted with far greater ease by the pomp and symbolism of Catholicism? If so, how could Holland, whose very existence as a nation sprang from her revolt against Catholicism in Europe, install that very sect in Java? Moreover, from the seventeenth to the nineteenth century it appeared to the Dutch, whether rightly or wrongly, that it was far more dangerous to allow the Javanese to become spiritually subject to Rome than to allow them to remain subject to Constantinople.

In 1906 the Reformed Church in Netherlands India numbered 38 ministers and 25 assistants, and the Roman Catholic Church numbered 35 curés and 22 priests; none of either sect received any payment from the public funds. There were also about 205 missionaries at work throughout the Indies. The number of Christians in Java and Madura was not more than 26,000; in the Outer Possessions there were 434,000. Compared with the total population, these figures appear quite hopeless.

None the less, the priests of the two cults play a very appreciable part, giving the Government valuable help in educating the natives, in imparting ideas of hygiene and 
morality, and in bringing them to a higher pitch of civilisation, especially in the Outer Possessions.

Moreover, we must not forget the number of learned Dutchmen-highly distinguished ethnologists, linguists, and historians-who have gone out to the Indies in the quality of missionaries.

Although the Javanese remains a Mahomedan with a certain pride in belonging to a great international community, he is none the less a Mahomedan with a minimum of fervour and orthodoxy. He regards all Arabs with great respect, as in his eyes they are all more or less remotely descended from the Prophet, and especially venerates the Hadjis; but he is not easily persuaded by them to abandon his ancient Hindu or animistic practices, such as offerings to Buddhist shrines; and although he observes the rite of circumcision, he refuses to fast and abstain from work on Friday. As a rule, he is ignorant of his religion; seldom goes to the mosque, and rarely says the five prayers. The people abstain from fermented liquors because they are naturally sober; but certain regents, and the Sultan and Susuhunan, do not regard the drinking of wine as an offence, in spite of the eminent religious position of the latter. The number of Javanese who accomplish the pilgrimage to Mecca, which is expected of every pious Mahomedan, is negligible (less than five thousand annually), although it has doubled in ten years; and many undertake it only to call oblivion down upon an evil past, or to add to a fortune, perhaps dubiously acquired, a certain amount of social consideration; or from ambition; or to join to other advantages a vague atmosphere of sanctity. Again, the Javanese does not observe Ramadhan, or the month of fasting, with very noticeable strictness, leaving that duty to the priests and a few santris. Of the three great yearly festivals of Islam-Maulid, 'Idu 'l-fitr, and 'Idu' $l$ Qorbân, which he knows as garebeg mulud, garebeg puasa, and garebeg besar-the Javanese makes very little of the first, which solemnises the Nativity of Mahomet; or of the second, or the feast upon the 
cessation of the fast; while he pays hardly more attention to the third, the garebeg besar, the great festival, or day of sacrifice, which takes place on the tenth day of the twelfth month, and should be preceded by a fast on the ninth day. On this occasion the pious Musulman must give alms, and must attend the mosque for prayer in common with his co-religionists. Even in the Vorstenlanden, which are centres of comparative religious fervour, these two festivals are most indifferently observed. The garebeg puasa is the most religiously solemnised. It falls upon the first day of the month of Sawal, bringing Ramadhan to a close. Whether the festival is badly observed or well, every one is delighted that the fast is ended; people bathe, wash their hair, put on new clothes, and set out to wish happiness to their friends and relations. Europeans have formed the habit of exchanging good wishes with the natives on the day of this festival, and some even believe that it represents the Javanese " new year." The Dutch Government has raised the garebeg puasa to the status of an official holiday.

In all provincial or district capitals the regent, on the day of the garebeg puasa, having received the respects of his subordinate officials, and having accompanied them to the mosque, proceeds to the house or palace of the Resident or Assistant, who awaits him, at ten o'clock, in full uniform. The regent announces that the feast is terminated, expresses his good wishes and those of his companions, and returns to his own dwelling. The Resident, in turn, proceeds to pay a similar visit to the regent; this is an occasion of pomp and ceremony, and after the Resident has in suitable phrases expressed his felicitations and those of the Government there is a thunder of cannon, a general exchange of congratulations, and popular games commence upon the alounaloun. At Djokjakarta and Surakarta, at the courts of the Sultan and Susuhunan, the festival is considerably more brilliant than elsewhere.

From the Laodicean temperament of the Javanese; and 
his profound politeness, arises his perfect tolerance in religious matters, and his utter lack of fanaticism; but we must not conclude that he is indifferent. $\mathrm{He}$ is a good Musulman because he believes and wishes himself to be one ; it is probable that even persecution would fail to make him abandon Islam, were such treatment ever to be adopted; for when once the quiet, reserved, apathetic Javanese, stung by too keen an injury to his self-esteem, has engaged in a conflict with Holland, his most formidable revolts have always had the appearance of outbreaks of religious fanaticism. It was so with Pieter Erberfeld, ${ }^{\mathbf{x}}$ whose name, after the lapse of two hundred years, is still upheld to execration upon the ruined walls of old Batavia; and also with another rebel of quite another complexion-Dipo Negoro, the

s The son of a German resident in Batavia and of a native woman, Pieter Erberfeld, who became a Musulman, appears to have been wealthy and influential. Thanks to the distribution of amulets made of little copper discs, he succeeded in surrounding himself with numerous partisans-they numbered nearly seventeen thousandamong whom a Javanese, Kartadrya by name, was particularly devoted to him. He had formed the project of expelling all Europeans from Java, and of making himself the ruler of Batavia, with the title of Tuan Gusti, or August Lord, while Kartadrya was to be commandant of the districts. It is said that a native woman betrayed the plot, which was dated for the rst of January, 1722. A number of conspirators were put to death, and Erberfeld was atrociously tortured, while his house was rased to the ground, and it was decreed that the site should never be built upon again. To this day, in old Batavia, not far from the church, one may see a blank wall on the top of which is a skull transfixed with a rod of iron. Below is the following inscription :-

OYTEN VERFOEYELYKE GEDACHTENISSE TEGENDEN GESTRAFTEN LAND VERAA $=$ DER PIETER ERBERVELD SAL NIEMANT VERMOOGEN TE DEESER PLAATSE TE BOUWEN TIMMEREN MET= SELEN OFF PLANTEN NU OFTE TEN EEWIGEN DAAGE BATAVIA DEN I4 APRIL A ${ }^{\circ}$ I722.
TO PERPETUATE THE ACCURSED MEMORY OF THE CONDEMNED TRAITOR PIETER ERBERFELD, SHALL NO ONE RAISE ON THIS SPOT

HOUSE, BUILDING, OR STRUCTURE NOR PLANT [ANY GROWING THING] NOW AND FOREVERMORE.

BATAVIA THE I4 APRIL ANNO I722. 
instigator of the great Javanese War, whose disappointed ambition and outraged dignity ended in a mystical exaltation, which was indubitably sincere, and in an appeal to all the centre of Java, calling upon the people to arm themselves for the prosecution of a holy war. Such also was the form assumed by the last exasperated risings among the famine-stricken people of Bantam.

III.

The problem of native education is even more complex, from the Dutch point of view, than the question of religion. It is not, however, a problem of very long standing: as lately as 1796 the Dutch Indian Company which was governing, or rather exploiting, the Dutch Indies, appeared to have no suspicion that such a problem could ever present itself. It confined itself to drawing from the soil the utmost that the soil could yield, concerning itself neither with the political institutions nor the social conceptions of its so-called subjects, lest the one or the other should stand in the way of its adroit extraction of the resources of the country. It is not certain that it could have done more, considering the means at its disposal ; certainly it appears never to have dreamed of approaching the subject.

The short but fertile French domination, followed by the rule of England, had of necessity to take action ir other directions; the question of native education was not touched upon, save in a purely indirect fashion.

Although when the Dutch, in I8I6, resumed possession of the Indies, the indifference with which the natives, with whom they had so little concerned themselves, had passed into the hands of other masters, without a regret for their old rulers, should have been a cruel but salutary lesson, the manner in which they resolved henceforth to enter into contact with their subjects was not, perhaps, as fruitful as it might have been, although at the outset it might have seemed the only wise method. 
Their policy was then, and for forty years to follow, that of respecting the natives and their institutions. Lest the Mahomedan susceptibilities of the Javanese should be awakened, the Dutch impeded, deliberately but sincerely, the efforts of the only class of people who were at that moment anxious to enlighten and develop the native mind: namely, the missionaries, Catholic and Protestant. In spite of the blunders which these latter committed-having first selected Latin, and afterwards Malay, as the medium of their education and evangelism - they would certainly, although their ambition of conversion might well have failed, have developed the mentality of the natives, if only by a step.

But the Dutch continued to leave the mass of the people prostrate in ignorance and servitude, under the direction of their own chiefs, although the intellectual insufficiency and regrettable immorality of the latter became always more and more obvious.

The famous Marshal Daendels, at the time of the French domination, had very wisely decreed, in 1808 , that all the regents of the north-eastern coast of Java should at their own expense create-thus leaving the Treasury unwrung - schools provided with able teachers, for the purpose of educating the natives according to their adat and their belief.

This decree, repealed by the Dutch, remained a dead letter. In I849 there were still only two regent's schools; these two being due to two regents who were full of initiative-those of Japara and Pasuruan. In I85I there were five, but so pitiful that they were hardly worth the trouble of maintenance.

They were, for the most part, "Koran schools," of an indefinite type, which a holy man-a panghulu or santri, $\mathbf{x}$ attended in a more or less regular fashion, giving

- Panghulu (Malay: Dutch transcription pengoeloe, or panghoeloe), the dean of a mosque; santri (Javanese), a student in theology, a theologian; a pious man who studies the Musulman religion. Religious establishments in which theological instruction is given are in Java called pesantrèn; the quarters inhabited by santris are 
the scholars a certain amount of religious instruction, reading to them, and making them learn by heart certain passages of the Koran. They might not infrequently increase the fanaticism of some of their pupils; they could aid in the development of none.

Good issued from the greatest evil ; from the infamous system of compulsory crops (Cultuurstelsel), conceived by Van den Bosch; the most immoral and gigantic spoliation to which an upright, generous, kindly people could ever have lent itself in its blind utilitarianism; a system from which Java is barely recovering to-day. This system, which was apparently a capital thing for Holland, since it enabled her, between $185^{\circ}$ and 1870 , deliberately to extract from her colony nearly two thousand millions of net profits, was realised by means of unjust deeds, legal exactions, and at the cost of human life, and it finally forced the ruling country to take two matters into consideration. One of these was the notorious incompetence of the regents, who directed the affairs of the system in their own provinces and shared the benefits: an incompetence which, together with their cupidity, was likely to drive the native to extremes, by aggravating the system by additional and useless acts of injustice. The second was the necessity of choosing among the natives innumerable subordinate employees, which this colossal system of exploitation required for its regular working, and as a check, as far as might be, against fraud. There thus arose the necessity of educating the natives employed from top to bottom of the scale; always with a strictly utilitarian aim.

This idea outlived the method of compulsory cultures, being taken over unchanged by the Liberal party which abolished the latter. But this time it was adhered to with the more respectable object of preparing natives of high birth to become worthy of being actually associated with the power of Holland, and to make the mass of the

known as pondok (root fondouq $=\pi a \nu \delta o \chi \varepsilon \tilde{c} 0 \nu$ ); the hall in which classes are held is called langgar in Java, and in the Sundanese country, tadjug. 
people capable of obtaining the best from themselves as well as from their soil. The law of 1854 was not voted without furious recriminations and desperate political struggles, and it was only in 1872 that it was put into execution. It is only fair to say that Holland-all that was most noble and enlightened in the country-the Van Hoëvells and Van den Puttes-immediately entered the most vehement protests against the immorality of the system of compulsory culture, and that the whole country attacked it without waiting for revolt or disaster in the colony, simply as the result of a determined appeal to its conscience. Moreover, from 1872 onwards, we shall find that Holland has been full of a general and maternal solicitude for the Dutch Indies; the fact is that her administrators have gradually learned the native tongues, and at last come into contact with them. Other functionaries, who have often been especially commissioned by the home authorities, have made a careful study, on the spot, of the native manners, beliefs, abilities, and ambitions; many misunderstandings have been cleared away, and after a long period of ignorance concerning her subjects, Holland is endeavouring to atone for the past.

It is essential, however, that the movement in favour of a system of serious education should obtain the immediate and ungrudging support of all its European advocates, especially those in the colonies.

At the outset there were many who, in their lethargic egoism, protested against the idea of educating the natives; saying that it was impossible to do so, or that they themselves did not wish for education, or that were they educated they would gain nothing by it ; they had lived for centuries without instruction, so that any attempt at further development, so far from bringing them enlightenment, would merely fill their feeble minds with discontent and chaos.

IV.

Two facts appear at length to be definitely established. The Javanese, who is extremely precocious, has also an 
open, adaptable type of mind, which has great powers of assimilation. Left to himself, he learns all the subtleties of his own very complex language, and also those of the Malay tongue; he has a remarkable knowledge of the names and properties of the plants and trees of his country; his faculty of locating himself, of being aware of the points of the compass, even in the dark, is generally known ; and all that appertains to design, geography, or topography he absorbs with the utmost eagerness. In school, thanks to his precocity, it often happens that he outstrips European children of his own age; and in some cases he is able to maintain this superiority for years.

Latterly, in short, whenever certain privileged individuals have obtained a full European education, we have seen that they make a very good showing, and have sometimes proved themselves of considerable value. It is therefore impossible to argue that the Javanese cannot be educated ; $^{\mathbf{I}}$ a fact which is now so generally understood that no one, save a few narrowminded autocrats, dares to continue to oppose the movement.

The native's passion for learning is perhaps even more firmly established than his aptitudes; young and old, all are ambitious to learn. When the first Normal Teachers' School was opened in Java, the cadets of the aristocracy rushed to enter it almost as precipitately as the people; perhaps because they saw in it, as did the people, a fresh possibility of becoming functionaries; but also because

* It would be easy to name the son or grandson of this or that regent as speaking and writing not only his own language, but Malay, Dutch, French, \&c., as well, and capable of passing very brilliantly in the higher examinations in Holland. A certain doctor in medicine might be named, also a fluent speaker of many languages, who is noted in the universities of Europe both for his acquired knowledge and his untiring intelligence. Dr. L. Serrurier, in the Catal. de la sect. Indes Néerlandaises à l'expos. col. d'Amsterdam (Leyden, I883), cl. xi., has a short biography of a Javanese painter, Raden Saleh Sarief Bastaman (I814-1880), who enjoyed a certain celebrity. One might easily lengthen such a list. 
they desired to learn, to raise themselves another step; and it was difficult to make them understand that the school was not for them. On the other hand, when the provincial schools especially intended for them were opened, every peasant who was in comfortable circumstances commenced to intrigue in the hope of entering his sons. The "schools for the sons of chiefs" in Bandung, Probolinggo, and Magelang in Java, and in Tondino in Minahasa, for the Outer Possessions, were very soon complained of as insufficient both in numbers and in the scope of their curriculum. The ambition of every regent's son was to share in the education which the Europeans were receiving in their own separate schools; to learn Dutch and the principal elements of Western culture.

It will be readily understood that in former years this enthusiasm for learning was neither so general nor so precise in its aim. From the year 1820 all the regents were bitterly complaining that they had been despoiled of their powers and the number of their prerogatives; that they were playing a wholly illusory part in the Java whose masters they had formerly been. Few would admit that their lives, devoted to the pursuit of pleasure and cupidity, together with their ignorance and their unjustifiable exactions, would scarcely have permitted them to have led a more active existence; still less did they admit the necessity of revising their education in order to make themselves fit for such a life. Only a few, like the regents of Japara and Pasuruan, and, later on, those of Demak and Karang Anjar, declared that the Javanese nobility could only retain its rank by submitting to the forces of evolution, and that the Dutch Government ought to assist it.

Many saw in the opening of these "schools for the sons of chiefs" either a futility or a snare by which the Europeans hoped to destroy their ancient customs, and turn the sons against the traditions of the fathers. For a time there were vacancies in the Bandung school, and the five regents of Bantam, a province greatly attached 
to Islam and adat, refused to send their sons there; but a Dutch official finally persuaded one of them to allow his son, who was a very gifted boy, to enter in spite of the objurgations of the others, and their gloomy prophecies. The tact with which the boy was educated, the extent to which he profited, together with the inborn taste of the Javanese for intellectual culture, triumphed over the old suspicion, and the four other regents immediately sent their sons to the school, which thenceforth had as great a vogue as the others.

Prolonged contact with Europeans, and the RussoJapanese War, which affected the Javanese merely as the friends of Japan, which means little enough, but which gave them, in common with other Asiatic peoples, the unexpected and pleasing surprise of seeing that the yellow man was capable of making use of European arms, and with them of defeating a European nation, could only increase this thirst for development from the top to the bottom of the social scale, while giving a more definite knowledge of the form which that development should take.

It is impossible any longer to refuse the natives of the East Indies the education which in Europe is compulsory, since they have shown themselves capable of profiting by it, and demand it. It would be puerile to raise the objection that they must be content with the neutrality which has been theirs for the last ten centuries; Europe herself has advanced only by a process of continual evolution; and since enlightenment and power proceed from Europe the Javanese demand that they shall receive their share. At all times attached to the soil, to the memory of their ancestors, and to their adat, but having, as they consider, exhausted the resources of their own civilisation, they demand the opportunity of renewing their strength by means of Western civilisation, so that they may extract from it all that will not obscure the originality of their own. ${ }^{x}$

× One may obtain some idea of the highly intellectual and perfectly loyal aspirations of the young Javanese aristocracy by ex- 
They affirm that their loyalty will be in no sense diminished, whatever the pessimistic may believe. They are faithful subjects of the Queen, they know all they owe to Holland, and that they could not for a long time to come dispense with the Dutch and rule themselves; but the upper classes which have hitherto been nominally associated with the exercise of power might not unreasonably hope to regain a certain degree of actual and effective power, by which not only they, but the whole social body, would benefit ; and the people, which is gradually developing a consciousness of self, perceives the possibility of improving its condition, both morally and materially, by a rational self-development.

The Javanese aristocracy are far from crying, "Java for the Javanese !" because, at the present moment, such a cry would be a piece of fatuous vanity. What they do cry is, "Give us light!"- - light under the maternal ægis of Holland, so that they may once more become worthy of their past, and of a still better future.

Hence the cry for a multiplication of the primary schools, where the natives could learn not only their own language and Malay, but, towards the end of their studies, the elements of Dutch as well ; where, above all, they would gain a certain practical knowledge of hygiene, agriculture, surveying, and accounts, and where they would receive salutary advice on the subjects of thrift and foresight, so that by yielding them more their native soil should become yet more dear to them, while some might be induced to enter upon commercial pursuits, which they have ignored only too long.

The more wealthy and intelligent, the sons of petty officials, or cadets of good family, might pursue their studies in the professional schools of agriculture and commerce, and would provide the administration with a solid framework of subordinate employees, and with the

amining the programme of a native league, the Budi Utomo, and the minutes of two congresses held by this league in October, 1908 and 1909, which I have given in the Revue du Monde Musulman, vol. vii., April, 1909, pp. 414-427 ; vol. ix., Dec., 1909, No. 12, pp. 612-620. 
nucleus of a class of native landowners educated along modern lines.

Others would pass through the Native College of Medicine at Weltevreden, which is attended by the sons of the priyayi and the younger sons of regents. ${ }^{x}$

The better equipped of these Dokters-Djawa, whose ardent though loyalist patriotism has already been remarked, would obtain scholarships or exhibitions which would allow them to perfect their training in the schools of Holland, which in their eyes are the source of all true knowledge.

The sons and heirs of regents and high officials are asking not for schools especially created for them, but for the right to enter the elementary schools (lagere scholen), then the secondary schools (burgerscholen, hitherto reserved for Europeans only), in the hope that afterwards, if they prove themselves competent, they may attend the universities of Holland, and there pass the same examinations as their Dutch fellow-students, with a view to entering upon the same careers.

This attractive programme, democratic in its liberality,

School tot opleiding van Inlandschen Artsen, or, vulgarly, the Dokters-Djawa School. It trains the Dokters-Djawa, or native physicians, who are of great service. At the outset they receive a salary of 50 florins per month, and hold the rank of assistant wedono of the first class (district under-chief). The curriculum in the School of Native Medicine includes the following subjects: Dutch, physics, chemistry, botany, materia medica, therapeutics, pathology, bacteriology, and minor surgery. A polyclinic has been recently added to the school. The lectures, \&c., are in Dutch and Malay. The course lasts three years in the case of pupils of the preparatory department, and six years in the case of the medical section, properly so called. The school is capable of accommodating two hundred students. The Weltevreden Hospital possesses as an annex a school for midwives (School tot opleiding van Inlandsche vroedvrouwen), intended to educate native women in European ideas of practical obstetrics, hygiene, and the rearing of children. They receive no fixed salary upon leaving the school, but may claim payment for their work.-Priyayi (Dutch spelling, prijaji), employee, official, and, by extension, any one who holds a place or rank, or is a person to be considered. But the word has especially the meaning, in the wider sense, of "gentleman." 
yet securing for members of the aristocracy the prerogatives which they have always been granted, would unhappily prove enormously expensive. It testifies to the native's touching and candid confidence in the modern deity, who finds none to deny him among the peoples of the Far East: the deity of progress, incarnated in the civilisation of the Western world.

All that Holland has already performed in the way of educating the natives guarantees the goodwill of the administration in this matter, and her resolution to complete her task.

In 1849 the budget of public education for the natives amounted to 25,000 florins, for one normal school and a few provincial schools. In 1906 it amounted to $2,318,35^{8}$ florins for five normal schools (three in Java and two in the Outer Possessions), with $3^{1}$ masters and 300 pupils, and 323 elementary schools with 74,984 pupils in Java and Madura alone, which were subsidised by the Government, and 446 private schools with 50,344 pupils. The result does not appear very considerable if we compare it with the density of the population and the money expended; but what colonial Power can boast of having done as much? Certainly not England in India, nor France in Indo-China.

Will the Dutch Government be able to go much further, and, with the help given by the private schools, succeed in satisfying all the demands for further schools which are pouring in on every hand? It is very certain that it will have to proceed more deliberately than the native aristocracy desires; the heavy expenses of public education, added to the cost of the Achinese War for the last three years, is causing a slight deficit in its budget; but it does not appear that this deficit will be increased. For the rest the movement is well afoot; everywhere the richer natives, often in conjunction with the wealthy Chinese, are offering to come to the help of the authorities in order that they may obtain their desire; and unless progress is the most illusory of chimeræ, Java is on the way to acquiring mental and moral characteristics which are worthy of attracting attention. 


\section{CHAPTER VII}

\section{THE ORIENTAL FOREIGN ELEMENT}

I. The Oriental foreign element in Java and Madura: the Japanese, Arabs, and Chinese. The Japanese are the latest arrivals, and the least numerous, but also the best treated.II. The Arabs : the religious and economic danger represented by the Arab element in the Dutch Indies.-III. The Chinese : their numbers, their activity, their wealth. Why they are considered detrimental to the political and economic power of the rulers, and the morality and prosperity of the native.-IV. The various solutions of the problem; their injustice, or insufficiency, or the impossibility of applying them. The only remedy is to educate the Javanese so that they may take their place as devoted collaborators and agents of the administration and the European industries.

I.

Besides the 29,715,908 Javanese, Sundanese, Madurese, and Malays, and the 64,9I7 Europeans who inhabit Java and Madura, the two islands together contain a further population of about 320,000 Orientals.

These may be divided into 295, I93 Chinese, I9, I48 Arabs, 2,842 Japanese, Armenians, Persians, \&c.

The Japanese, who do not exceed 1,800 , although the latest comers and by far the least numerous, are none the less the best treated.

Since the possession of Formosa, taken from the Chinese, and the happy issue of the Russo-Japanese War have given them a preponderant position in the Far East, we see them going forth on every hand, bringing with their national pride their curious intelligence, alternately adaptable and arrogant, their activity and 


\section{ORIENTAL FOREIGN ELEMEN'T 155}

powers of assimilation, which allow them to appear, in the eyes of the rest of Asia, as having won the victories of Western civilisation. They have the double advantage of being of the same racial strain, yet of appearing to be as "strong" as Europeans; so that in the Dutch Indies, where this gives them a dangerous superiority over the other yellow races, they have obtained the favourable treatment reserved for Europeans.

This fact contributes not a little to increase their prestige still further in the eyes of the natives; already native papers abound, on the fourth page, in Japanese advertisements, wherein physicians, apothecaries, and shopkeepers of all kinds offer the Javanese, in terms adapted to their mental make-up, the last effort of Western science, or its most finished products. They are trying to oust the Chinese from the market; and their initial move, although not as yet formidable, in view of their scanty numbers, at all events manifests their perfect competency for that purpose. So far it would be almost as absurd to exaggerate their nascent influence as to ignore it.

Although the Japanese, legitimately proud as they are, and perhaps a little carried away by their late success, are seeking to make friends of the people of the Archipelago, of whom a more or less plausible theory makes them the distant cousins, it does not appear so far as though the native masses are particularly impressed. The aristocracy alone recognises their significance; but has been more than once repulsed and wounded by the intractable pride with which the Japanese have long been reproached, and which makes it less easy to do business with them than with the adaptable and obliging Chinese; and the example of their relentless seizure of Korea has given many pause to think.

II.

With the Arabs, on the other hand, the Javanese has powerful religious affinities, and the habit of long-estab- 
lished intercourse. From the earliest times, moreover, the small Arab community has exercised a living influence upon the life of the island, and on several occasions has caused the Dutch Government some anxiety, though perhaps without very good reason.

As a rule, Europeans make two complaints against the Arabs. Firstly, they accuse them of pan-Islamic tendencies; they fear that they will awaken, as soon as they can, in the name of a community of faith, the fire of fanaticism in the lethargic, tolerant mind of the Javanese, and will direct it against the Dutch ; secondly they complain that their bad faith in matters commercial, and their usurious habits of business, are undermining the economic prosperity of the Europeans in Java, and are even more harmful to the natives.

These two grievances appear to correspond with the two categories of Arabs who inhabit the Dutch Indies. On the one hand are the Hadjis and santris who visit Java in order to watch over its orthodoxy, and to reanimate the faith of the natives, and the few influential heads of Arab communities in the large towns, who are more or less the spiritual directors of such communities; on the other hand are the traders and travelling merchants.

The Javanese retains a certain traditional respect for the Arab, who was formerly his religious sponsor: he regards the Arab as of the noblest race of all, because he is descended more or less remotely from Mahomed, and because he is a Musulman.

For the rest, it is indubitable that among the Arabs of the East Indies are some of a rebellious type of orthodoxy : often smitten with the ambitious dream of panIslamism, by which the Musulman of the East who has been subjected to the intellectual hegemony of the West attempts as far as may be to console his pride. It hurts them to see the Indies, where formerly they were morally predominant, still in the hands of the infidels; but this vague and secretive state of mind rarely betrays itself by overt acts; only in a few individuals does it find open expression. Nearly all the Arabs maintain an 


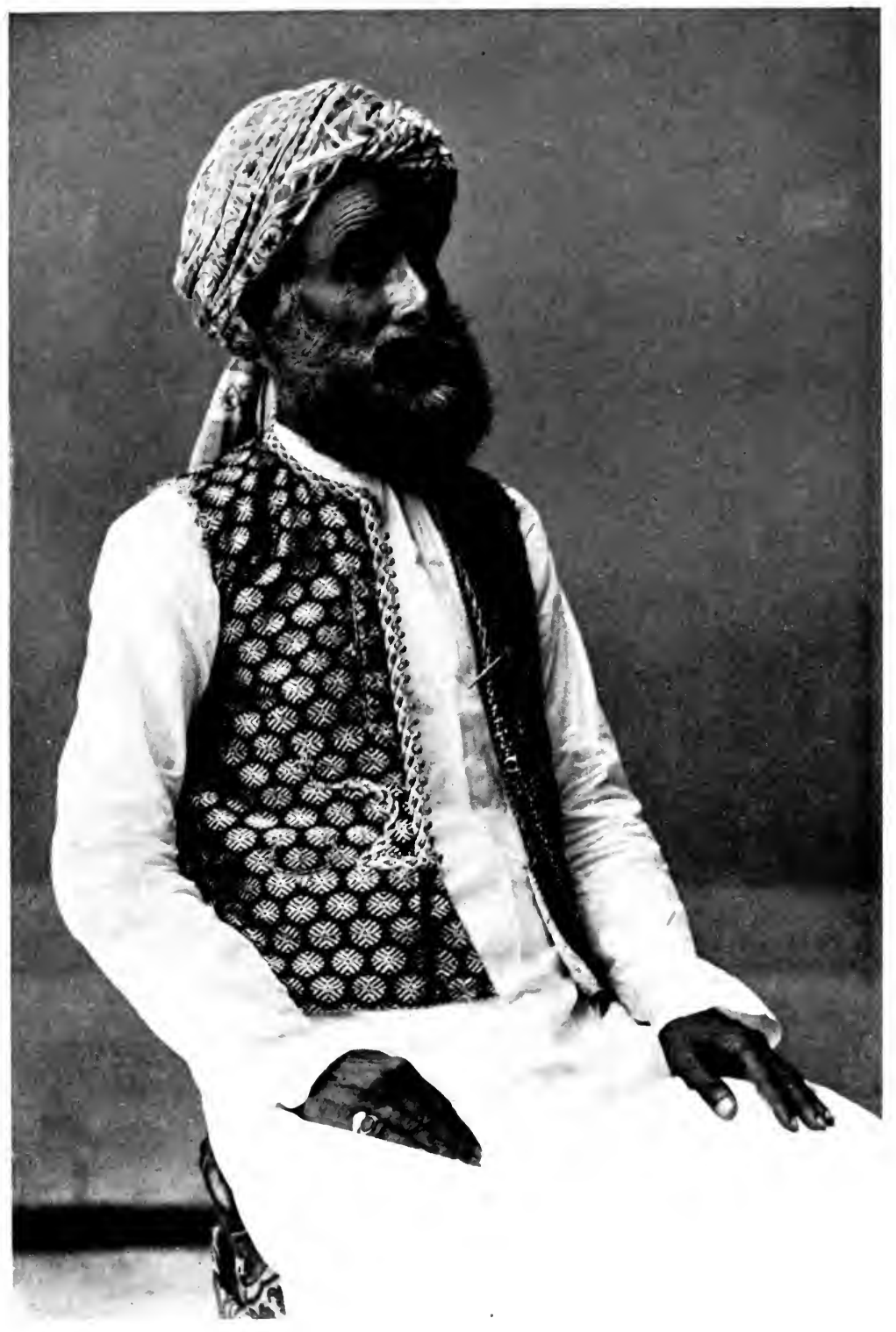

IN ARAB TRADER, SLRABNA 

attitude of extreme propriety with regard to the Dutch authorities. The best, who are also the most highly placed, by reason of their enlightened views of religion and of justice : the others because they know themselves weak in the presence of a well-organised power. With the exception of a few petty and unfortunate intrigues on the part of subordinate Turkish agents, all the religious disturbances of the last thirty years have been the work not of Arabs but of Javanese or Malays, who have returned from $\mathrm{Mecca}$, having there been transformed into fanatics by the retrograde beliefs and impossible hopes upon which the colony of Djawas still nourish themselves. The Dutch have had far more trouble with the Javanese and Malay pupils of the Arabs, who have been influenced by the dangerous and fanatical atmosphere of Mecca. ${ }^{\mathrm{I}}$

There is more to criticise in the commercial habits of the Arabs. Their name in the Far East, as in France in the eighteenth century, is synonymous with usury and deceit. As regards their dealings with the Europeans, their economic competition with whom is complicated by a sullen political hostility, they are accused, with only too good reason, of failing to meet their engagements; of abusing sleeping partners and vendors by a comedy of probity, which they sometimes prolong for years, and then, just as they have negotiated a heavy

I "As early as the eighteenth century there were groups of East Indian Mahomedans of considerable importance in Mecca, which had already been established there for some time; they were the nucleus of the colony of the 'Djawas,' or Musulmans of Malay race, which is to-day so numerous, and which comprises natives from all parts of the Indian Archipelago." Dr. C. Snouck Hurgronje, La Politique du gouvernement des Indes Néerlandaises à l'égard de Hadjis (trans. into French by T. J. Bezemer in the Rev. du Monde musul., vol. viii., Nos. 7-8, p. 40I). In Mekka, a work by the same author, in the last chapters of vol. ii., is a curious study of the colony of the "Djawas." The Rev. de lhist. des relig., I908, has also published an article by Dr. Snouck Hurgronje entitled l'Arabic et les Indes Néerlandaises, which is the opening lesson in his course on Arabic at Leyden University. 
loan, or a large purchase on credit, of taking flight like common swindlers. As regards the Javanese, who started by regarding them with favour on account of their community of belief, they are accused of shameless usury, and of urging the Javanese, credulous and imprudent children as they are, to ruinous purchases on credit.

The only remedy, supposing these grievances to be well founded, is for the European to take such precautions in doubtful transactions with the Arab that the latter, who is naturally a good man of business, is quickly made to feel that his only chance of trade in the Indies lies in honest dealing; this is a lesson which, if necessary, must be taught him against his will. Suspicion on the part of the customer is always the beginning of honesty on the part of the vendor.

Similarly, the best means of delivering the heedless and extravagant Javanese from the yoke of the Arab in matters commercial is to enlighten him as to his real interests; to educate him in business matters, in order to teach him to look after himself. A man is never better defended than by himself.

\section{III.}

The Chinese question is more complicated, because the Chinese possess three important advantages: numbers, wealth, and ability. In every important city they form a thickly peopled colony : there are 28,150 in Batavia, 13,636 in Samarang, 16,843 in Surabaja, 5,266 in Djokjakarta, and 6,532 in Surakarta; one finds them wherever there is money to be made; and their presence anywhere is enough to denote some known or possible source of gain. ${ }^{x}$ The Dutch say they collect like vultures

$\therefore$ "These strangers (the Japanese and the Chinese) are as the Jews, and even worse; they go never into any poor or barren land, but live always and traffic in those countries where milk runs and honey, where they may derive profit" (Gabaril de S. Antonio. Successos del reyne de Camboxa (Valladolid, r604), fol. 78. The period of which he speaks dates from 1580 to 1600 ). 

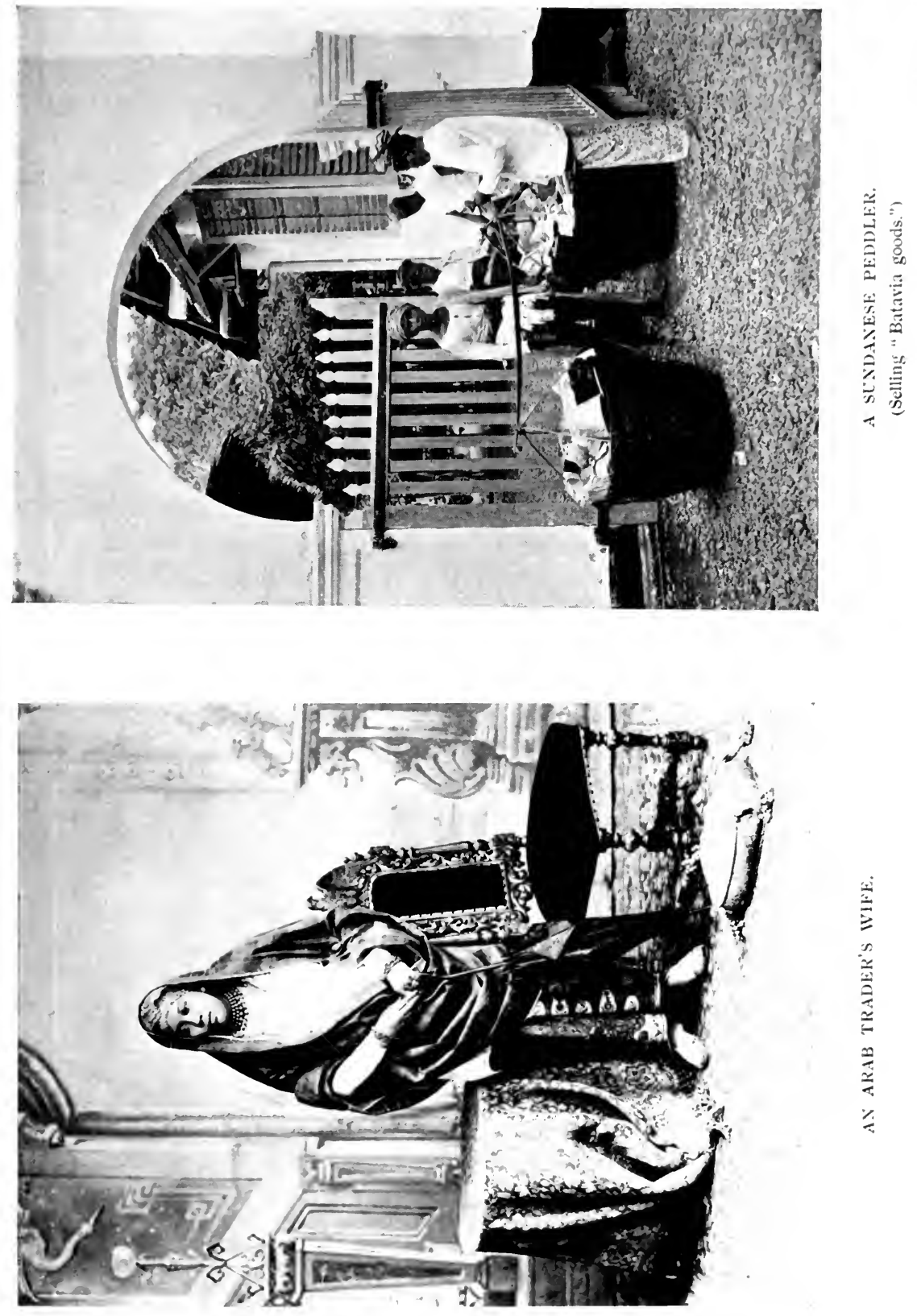

about their prey. The Chinamen, so one always hears, arrives emaciated, naked, with an empty stomach, and without a sou; but, once in Java, by force of work, adaptability, sobriety, and activity always alert, in the space of two years his purse and his stomach fill out, so that he is able to leave the master tailor, shoemaker, shopkeeper, or manufacturer with whom he first took service. He begins to work for his own profit. Very often a pedlar or packman, were it only to gain a better knowledge of the country, and to go adventuring after that continually looked-for occasion, the chance of a certain fortune, he sets out, indefatigable, with a complaisance that nothing can rebuff, so that when he returns from his tour, with his money-bags fuller, and the richer by a profound experience, he is ripe for larger enterprises, and he knows where to find them.

Thus patiently the Chinaman becomes one of the great owners of the island, whose luxury exacerbates the envy of the Europeans; a drain upon the public fortune which must not be overlooked. The value of Chinese property in Java is estimated at $f \mathrm{I} 6,000,000$.

A buyer and a seller of all kinds of merchandise; a manufacturer who will buy and renovate abandoned workshops; a farmer of State monopolies, which he nearly always obtains through always having ready money, and having obtained, oppresses the people without remorse in order to regain his money and his profit; a lender of small sums by the week and a large banker; always smiling and supple, whatever be his fortune, where he smells a profit; pitiless to his creditors, whose debts he will impudently increase with the utmost effrontery, and on whom he will cheerfully bring complete ruin; such is the Chinaman. He has, in short, all the intelligence and all the crude immorality of what men agree in calling "a man of business."

The Europeans in the Indies, as formerly in IndoChina and other Asiatic countries, complain furiously of the Chinaman; and their angry protests are not always without foundation. They reproach him with creating 
a dishonest competition, and with ruining the Javanese. The competition between Celestial and European is no new thing in the Dutch Indies. When the Dutch, the victors over the Portuguese, wished to extend their rule to Java, they had far more trouble with the hostile Chinese merchants, who had been in the island for centuries, than with the open revolt of the Musulman princes. It is only fair to say that they often made the Chinese pay in the cruellest fashion; for the struggle was desperate between 1737 and I74I, and many Chinese were put to death.

The scission of the ancient kingdom of Mataram into the two Principalities of Djokjakarta and Surakarta took place in the second half of the eighteenth century, simply to punish and thenceforth to prevent the secret assistance which the Susuhunan had lent to a horde of Chinese who had offered to rid him of the Dutch. The Chinese, despite their number, were massacred without pity, and the Susuhunan, although it was not obvious at the time, paid with the half of his territory for his tacit connivance in the intrigue.

Slowly deprived by the Dutch of their political predominance, the wily Asiatics took their stand anew upon the economic battle-ground; the Europeans today complain that they ruin the market by offering goods similar to theirs at a far lower price, thanks to the incredible conditions under which their newlylanded countrymen are forced to work, and because they themselves can live on nothing. Thus at one stroke they exploit their own countrymen, the Europeans, and the Javanese, whom they persuade into making unreasonable purchases of articles whose value is as inferior as their price is low. The argument is just a little specious; it is true that the Chinese, who by reason of his Asiatic birth and his tastes lives under conditions which are infinitely less costly than those of the European, can sell at an infinitely lower price, even without the outrageous exploitation of his own poorer compatriots; this is an advantage of race which he will 
always retain. But if the Chinaman were not there, can we be certain that the native would enjoy any other advantage than that of paying the European very dearly for articles that might be excellent, but beyond his means? The European is suffering from the hard law of economic competition; if he wishes to triumph, he must play other cards than the expulsion of the Chinese, who have by now become one of the indispensable factors of the prosperity of the Indies. $x$

What would become of the European and the Dutch Government without the presence of the Chinaman in Java? A hard worker, meditative, mindful of his responsibility, he is the linch-pin of all great public or private enterprises; to the native the necessary intermediary, the obscure but necessary cog-wheel, the middleman, the go-between, whom the European would not and the Javanese could not as yet replace. One finds him everywhere; one needs him everywhere; one must therefore accept him, while limiting, as far as possible, the bad effects of his rôle.

One thing is undeniable : that although the Chinaman may penetrate to the heart of the remotest kampongs,

I The chief reasonable objection to the Chinese is that they are apt to remove large sums of money from the country; though in the case of business concerns descending from father to son this is not the case. But even where it is the case we must remember that the Chinaman's fortune is only his wages for distribution; it does not matter to the Javanese whether a Chinaman or a railway brings his goods. After all, the Chinaman is an element of national prosperity; for of the money he receives much goes to his employees, who use it to purchase food from the Javanese; he also imports and exports goods. The Dutchman almost invariably retires with his fortune to Europe ; the Chinaman does not always take his fortune out of the country. In any case that fortune is the wages for transactions that bring money to Java. Thus the objection to him is that of a jealous rival; he is less of a drain on the country than the European. To impose death duties and to teach the native thrift and self-control would make the Chinaman still more harmless as regards Java; while the Europeans should seek to develop those branches of commerce in which the Chinaman cannot compete with them.- [TRANS.] 
there to introduce the goods, the tastes, and the needs of more civilised races, he is often accompanied by ruin. For the man he has to deal with as customer is the most irresponsible and prodigal of clients, utterly incapable of weighing the consequences of his acts, desiring everything, just as does a child, without stopping to consider whether he will ever have the means of payment. The Chinaman demoralises him by his insistent and insinuating offers, makes him buy beyond his needs, and allows him to buy upon credit, which is nearly always the best form of legal theft when one has the poor to deal with. He furnishes the deadly even more willingly than the useful; he will rather sell opium ${ }^{x}$ than cloth; he will lend at outrageous rates of interest; will take all the native's possessions in payment of a trifle; deceives him in the smallest accounts; and having first appeared as the most obsequious of servitors, he reveals himself as the most pitiless of masters. For this evil, although it is proven, there are no remedies excepting one, the efficiency of which some Europeans distrust as much as they distrust the Chinese : to educate the Javanese until he can defend himself against his own puerile covetousness, and against the temptations of the Chinese, so that he may gradually collaborate with the European in supplanting them. Such a task would be long and far from easy, yet undoubtedly possible. Ten years ago the train running between Batavia and Surabaja took two whole days for the journey; the passengers slept at Maos, as they were assured that the train could not proceed by night; the thoughtlessness, irresponsibility, and idleness of the native drivers and stokers making it out of the question to trust them for a night journey. For some time now they must have reformed themselves in these particulars, for the train pursues its way by night as well as by day. Such cases are seen everywhere, and indeed it is probable that the Javanese,

₹ The Sundanese, thanks to the Chinese, have begun to consume a deplorable; amount of opium, although fifty years ago they scarcely knew of its use. 


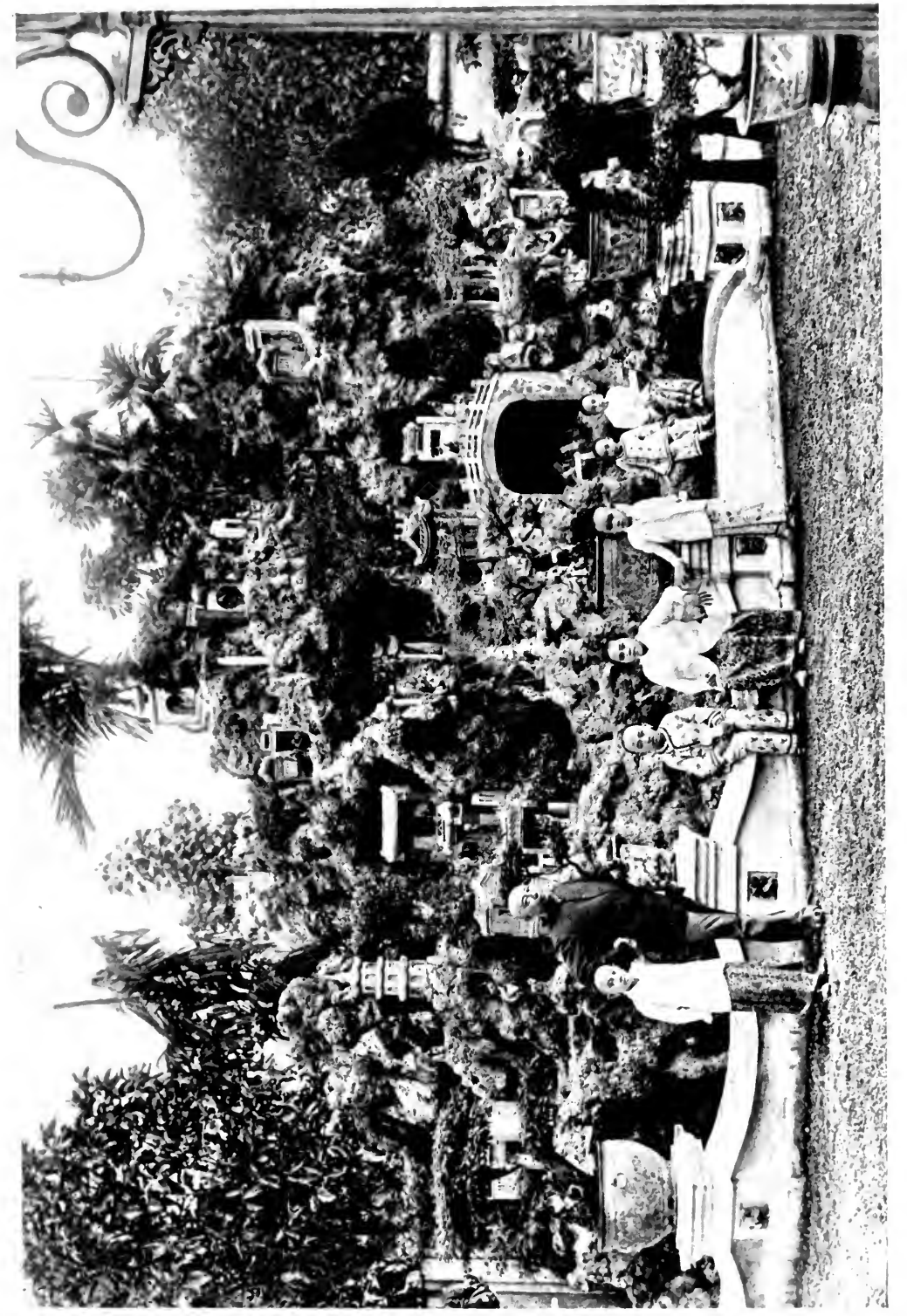





\section{ORIENTAL FOREIGN ELEMEN'T 163}

having hitherto played an absolutely subordinate part in all important undertakings, may nevertheless one day be able, if only they are given an appropriate education, to assist the Europeans in ousting the Chinaman. It is a desirable consummation.

\section{IV.}

In the meantime the harshness of the Chinese influence might be mitigated by progressively abolishing the process of farming out monopolies, taxes, \&c., the recovery of which is so oppressive, and often so unjust, that the State contracts for them in order to be rid of the business. Even the most case-hardened of Europeans sicken at the business, so that it passes almost entirely into the hands of the Chinese, who often squeeze double the legal tax from the poverty-stricken natives. The opium monopoly has already been almost entirely wrested from the Chinese by means of a scheme of excise based upon that employed in Indo-China, greatly to the benefit of the native's intelligence and his savings. The native is being gradually weaned from this dangerous drug, while the Chinese vendor used to force its consumption by every possible means. I It is equally urgent that the monopoly of lending upon pledges should be withdrawn from the Chinese, as they abuse it in order to despoil the natives, although the system was originally intended to help them. This is nearly all that can be done at present.

It seems hardly possible, either morally or materially, to deport the Chinese, and a matter of great difficulty to confine them, according to the methods of another age, to a few ports. To be frank, it is necessary to reckon with the enormous State which stands behind them, and also with the economic power which they

' See W. P. Groeneveldt, Rapport over het opium monopolie in Fransch Indo-China in verband met de vraag in hoever beheer in régie van dat middel voor Nederlandsch-Indië wenschelijk is (Batavia, I89o, large 8vo). 
represent, as was proved by the decree of 1837 , prohibiting further Chinese immigration into the Indies, which had to be repealed. On the other hand, since their complete political docility is assured by their organisation into communities, which are subject to the commands of a "major," "captain," or "lieutenant," appointed by the Dutch authorities, would not the simplest plan of dealing with them be to "Javanise" those who are in the island, and to limit further immigration, especially of women? For the Chinese woman is the chief danger; she creates a home abroad for the immigrant; a home foreign, if not hostile, to the Indies.

Impenetrable though the Chinaman seems to be in his inner self, he is really extraordinary in the ease with which he adapts himself to his surroundings. When fortune smiles upon him he seems at once to be at home, and if he is not wealthy enough to have his wife sent over from China he will take a wife in Java, or at least a concubine, who is of the utmost value to him in his business, on account of her profound knowledge of his world. Again, the concubine is often extremely useful to him in his schemes for obtaining land; for example, she will lend her name to the purchase of a plot of land, supposing it to belong to a territory which is now forbidden him, and which becomes a portion of the real estate which he and his compatriots have gradually accumulated, either when the State was alienating its territory, in the eighteenth century, or when private individuals have sold their own holdings, which were bought at the same period. Attached to Java by reason of their affection for the soil, and the families they have reared in the island, there are very few chances of their returning to China; in the majority of cases the Chinaman's Javanese wife and children alone are sufficient to retain him in the island. Although some, after amassing a fortune, abandon their temporary families and return to China, and although some of those who temporarily settle in the Indies, having brought their families with them, come with the sole end of amassing money, there 


\section{ORIEN'TAL FOREIGN ELEMEN'T 165}

are also many who will settle for good, and their children will be only half Chinese, while their grandchildren will be Javanese, with a superiority in the matter of education and business traditions which will greatly facilitate their progress. These latter only should be favoured.

It is worth remarking that in many localities the Chinese, allied by ties of blood with the native Malays and Javanese, ask nothing better than a community of interest with these latter. They even issue some Chino-Javanese newspapers in which their demands are published, and which help the Javanese to fight the good fight in order to force their way into the European schools and obtain their share of Western culture. For the Chinaman, so obstinately conservative in his own country, elsewhere demands, although his object is purely utilitarian, the knowledge which will the better enable him to struggle against his economic competitors. I It would indeed be strange, however vigorous their personality, if in the long run a fixed population of some I50,000 Chinamen, married to native women, could not be absorbed by a population of more than $29,000,000$.

As for the means of restraining the immigration of the Chinese without notorious harshness, it would seem that a system of taxes, comparable to that already in successful operation in the United States, should be sufficient in Java, if the taxes were adequate.

Besides an annual poll-tax, a comparatively high entrance duty, and a tax upon revenue and industry, the Dutch Government should demand of the new-comer the possession of a trade, a surety, and savings enough to prevent his immediately becoming a burden on the colony or fattening himself entirely at its expense. But measures of this sort, if half-hearted, lose their pro-

* Numbers of the Chinese established in the East Indies speak Dutch, and of ten English. It seems that there is talk of publishing a newspaper in the Dutch language, subsidised by the Chinese, which will uphold their interests. At the present time the Malay press in Java is almost entirely in their hands. 
hibitive character; they must either be re-enforced or renounced.

The great drawback to the employment of such measures is that the inequality of such treatment, compared with favourable treatment of the Japanese, would be rather too flagrant. Since the Japanese have been treated with consideration, the Chinese insistently demand similar consideration, and they can only be denied by sheer right of sovereignty. Despairing of obtaining equal treatment by straightforward means, some have hit upon a ruse which is natural enough, but little likely to conciliate the sympathies of the colonists; they proceed to Formosa, in order that they may, after being settled there for some little time, become naturalised Japanese, and then, with all the privileges enjoyed by the latter, deliberately settle down in Java. It is probable that such as these, who will soon be of three nationalities, will hardly be in the most formidable category of Chinamen in respect of the natives.

It is true that the competition between Chinese and Japanese will probably lead, without much delay, to the elimination of these too newly-branded Japanese.

Nevertheless, in an age when the employment of violent measures against a whole category of individuals is always futile or dangerous, we must repeat that the best means of defence against the preponderant influence of the Chinese in Java is to teach the Javanese, who are teachable in the extreme, to beware of them, and to replace them as quickly as possible in practically every employment into which they have insinuated themselves. ${ }^{\mathrm{I}}$

x Concerning the Chinese question in the Dutch Indies, see the following works: G. A. Romer, Chineezenvrees in Indië, cited from Vragen des Tijds (Haarlem, $1897,8 \mathrm{vo}$ ); W. de Veer, Chineezen onder Hollandsche vlag (Amsterdam, 1908, 8vo). 


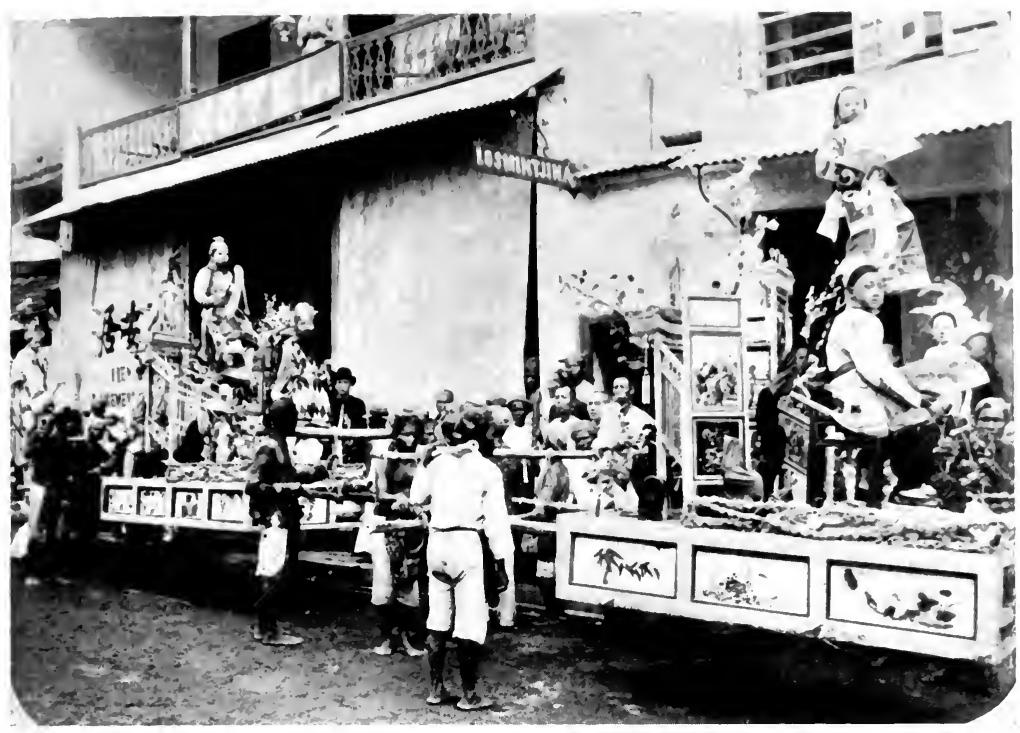

THE CHINESE NEW YEAR'S FESTIVAL

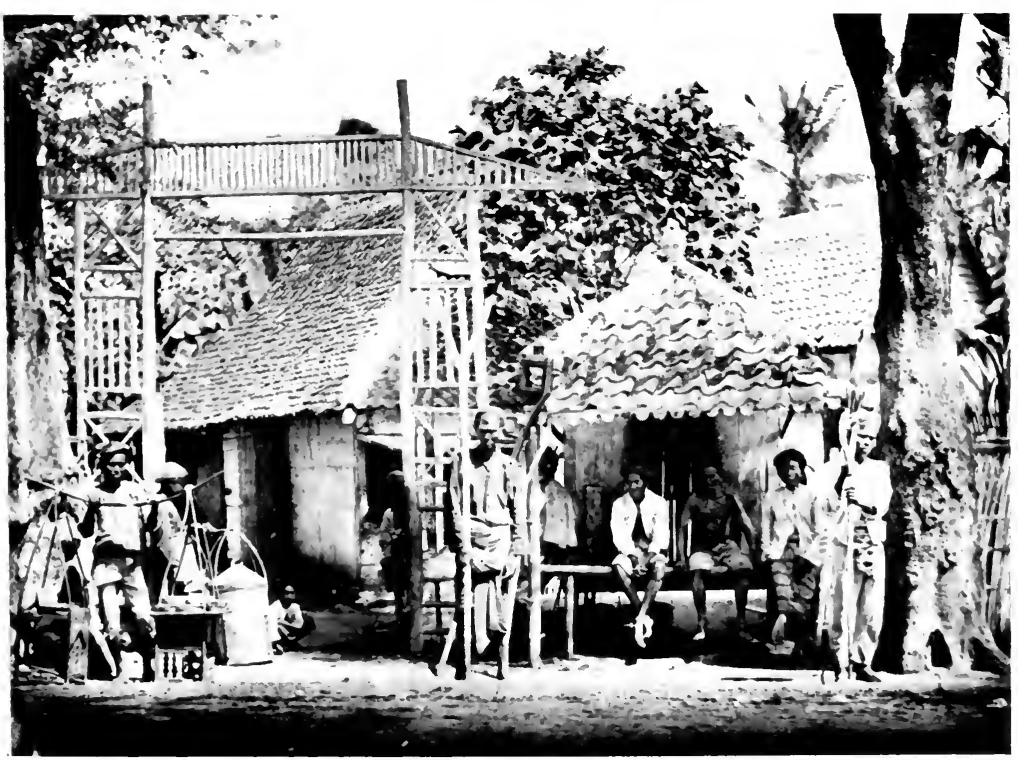


. 


\section{CHAPTER VIII}

\section{EUROPEANS IN JAVA}

I. The three aspects of the European element in the Dutch Indies : army, colonisation, bureaucracy. The army.-II. The colonists: foreigners, and why so few settle in Java. The French colony.-III. The Dutch colony. Its relations with the State and the natives; despite the vast area of the planta. tions, there are few private freeholds; the planter is the tenant of the State or of the natives; sometimes of both together.IV. His life: his house, furniture, and costume; his food, servants, and amusements.-V. The instability of European families in Java; why they do not settle there without thought of return.-VI. The half-breeds.

\section{I.}

THE Europeans and those of mingled European blood form a population of 80,910 in the Dutch East Indies : of these 64,917 are in Java and Madura. These figures do not include Europeans serving in the army, whose numbers are 10,732 , not including a reserve of 2,200 officers and men.

This colonial army (leger), which attains the total war strength of 33,682 , is an organism in no way connected with the national army of Holland. It always contains a proportion of one-third of Europeans to two-thirds of natives, excepting in the case of crack regiments, where this proportion is reversed. In the native companies the officers and a large number of the non-commissioned officers are Europeans; in the artillery the gunners are always Europeans, while the drivers, \&c., are natives.

The army is recruited in Europe and in the Indies, by voluntary enlistment. The officers are drawn almost 
entirely from the Dutch army, and have usually passed through the military colleges of Kampen and Breda. Besides an initial kit, the sub-lieutenant receives a lodging, or an allowance for the same, and a minimum pay of 170 florins a month, which increases, according to the rank obtained, to a maximum of 2,000 florins for a lieutenantgeneral of troops. At the end of forty years of servicetwenty in practice, the years passed in the Indies counting double, like the French "campaigns"-he obtains a retiring pension which varies from $I, 200$ to 9,000 florins per annum.

The non-commissioned officers and privates are paid according to their country of origin and the arm with which they serve. The daily pay varies from o fl. 33 to o fl. 44 for the European, and from o fl. 2 I to o fl. 25 for the native. To this is added uniform, $\mathbf{x}$ food, lodging for men and families, and supplementary rations proportioned to the needs of each. Here we have not the least original point of the colonial army: each soldier has the right to lodge with himself in the barracks his wife or concubine and their children; he may even, under certain circumstances, take them with him on campaign; these measures, against which morality occasionally fulminates, are designed to attach the soldier to his hard calling, which is not merely a temporary affair as with the mass of soldiers in Europe, while granting the advantages of a family or a very' modest harem. Their most obvious result is to turn the barracks, however neatly they are kept, into a squealing nursery, and to enrich the colony with half-breeds of all shades and races.

The majority of the white soldiers are Dutch. To these we must add a small contingent of deserters and adventurers : German, English, Belgian, Swiss, and a few French.

Among the natives the most valued are the Amboinese, for their fidelity and intelligence; and the Javanese, for their disciplined obedience.

- Only the European and Amboinese soldiers wear boots or shoes.-The florin is one-twelfth of the pound sterling. 
The officers of the Dutch colonial army have the name of being remarkable trainers of men ; full of initiative and technical knowledge; and as there are always disturbances here and there in so large an empire, they have scarcely the leisure to lose either of these qualities.

\section{II.}

Outside the army, the Europeans are divided into colonists and officials. The Indies have been open to neither for any great length of time. The Commercial Company or East Indian Company, which obtained a monopoly of the trade of the Indies and retained it until I796, when its liquidation was announced as the result of a bankruptcy amounting to more than $f_{10} 0,000,000$, dealt with the Indies for purely commercial ends. We may say that it came to figure as a sovereign power against its will; as it was obliged to reduce by force of arms the native states which refused the only thing for which the Company sued, namely, a certain quantity of the products of the country: spices, cotton thread, vanilla and cinnamon, for which it paid little or nothing, according to circumstances, and sold at very high prices in a market whose rates the Company itself established, thanks to the absence of competition. By such means it earned enormous profits. It was in nowise inclined to squander them upon Imperialistic expeditions, which is the reason why it conquered, almost in self-defence, its immense possessions, according to the degree in which they might maintain or increase its profits.

Neither had it any ambition to share its possessions with the Dutch nation; at the best it shared them jealously with its shareholders. It did not intend that any Dutchman should set foot in the Indies, excepting a few agents and employees, carefully recruited, with an eye to their capacities or their unscrupulous loyalty to the Company. It wished to behave as suited it, and to take everything for itself. For the people of Holland, accordingly, Java remained a strange and distant land, 
very beautiful and wealthy, but a forbidden land, by which one could benefit only indirectly.

The Company attained its climacteric between $16_{54}$ and 1678 , when John Maetsuyher was Governor. Immediately afterwards the decline set in: slow, but irremediable, in spite of the efforts of the six Chambers and the famous Council which was the soul of this mercantile oligarchy. In spite of the jealous care that was tal. nn to reduce to three or four species the spices which were grown for the Company in certain islands, which were narrowly watched in order to guard the monopoly, the European market finally contrived to supply itself from America and Africa; the establishment of the English in India was also to bring ruin upon the Company by a still more formidable competition, which still further lowered prices; and this ruin was finally consummated by the unlicensed luxury of the Company's agents, who, in spite of various sumptuary decrees, insisted upon appearing everywhere with the pomp of Asiatic potentates, and, when the coffers were empty, of procuring money by oppressing the natives, who rose against them; whence a series of costly expeditions..$^{\mathbf{x}}$

The war with England caused the rotten pear to fall. In 1798 the Crown of Holland displaced the Company, and proceeded to draw the greater part of the wealth of the Indies. The Crown, it appeared, had no idea of repairing the errors of the Company; it was equally careless of the needs of the natives; it distrusted all Dutchmen who were not in its service; it had the same utilitarian and egoistical conception of exploiting the

× Concerning the privileged Company of Commerce in the East Indies see De Geoctroijeerde Nederlandsche Oost-Indische Compagnie, by Baron G. G. d'Imhoff ; Considérations sur l'état présent de la Compagnie Hollandoise des Indes Orientales, relativement à sa navigation, à son commerce, et à son gouvernement; et sur les moyens de remédier aux causes de sa décadence (La Haye, P. de Hondt, I763, 4to) ; J. P. I. du Bois, Vie des Gouverneurs généraux; A. Chambalu, Die Holländisch-Ostindische Gesellschaft (1602-1798) kein Voebild für unsere Kolonisationsgesellschaften (Cologne, r89r, 4to); Dr. S. van Brakel, De Hollandsche handels-compagnieën der zeventiende eeuw. Hun ontstaan. Hun inrichting (The Hague, 1908, large 8vo). 


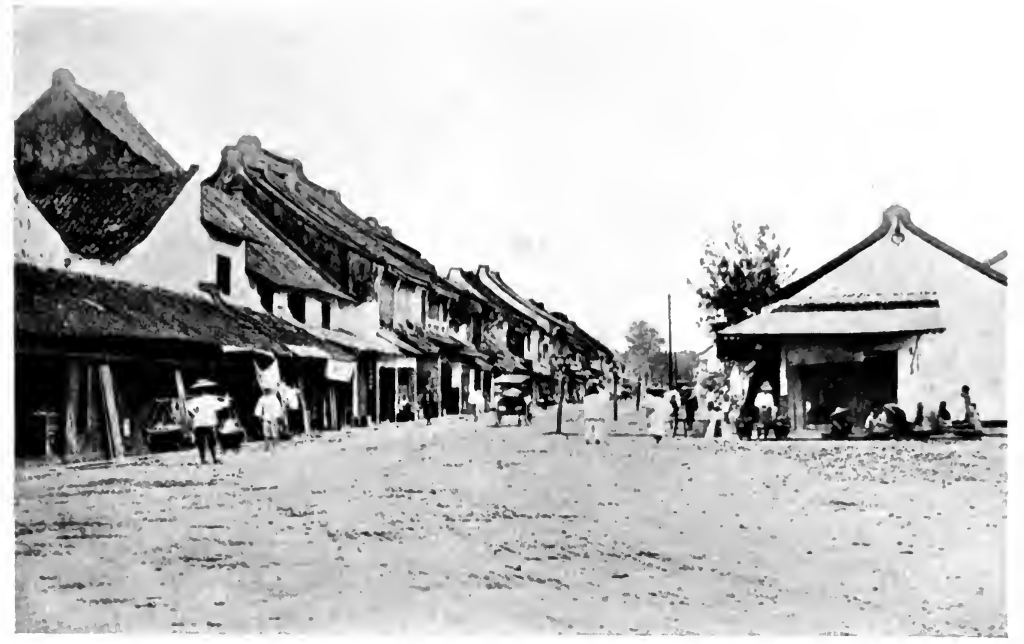

CHINESE KAMPONG, BATAVIA.

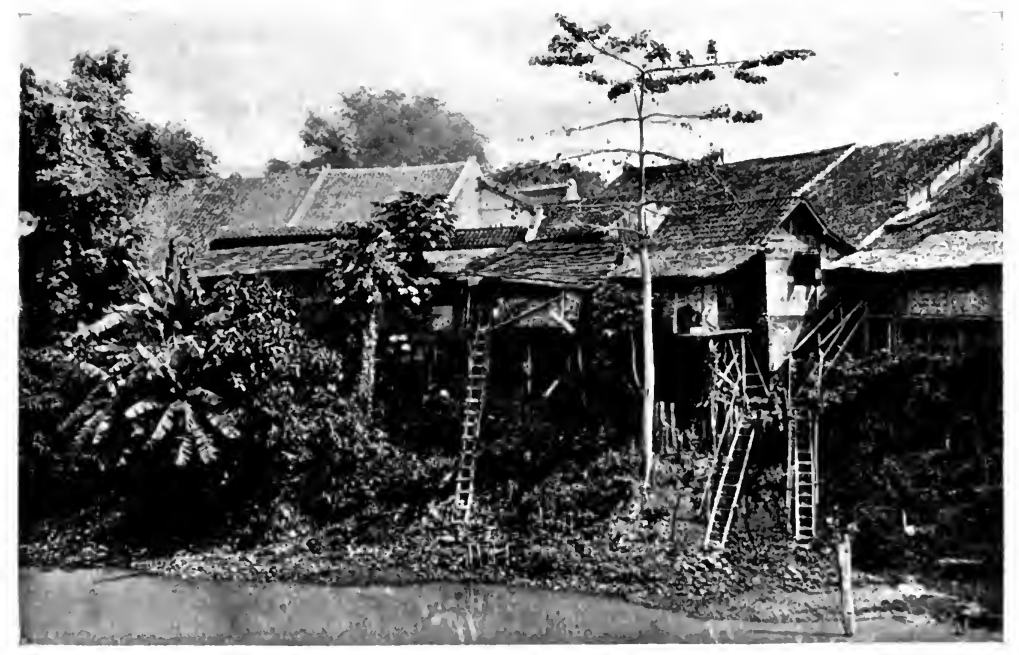

THE BACK OF THE CHINESE KAMPON(i, BATAVIA. 

Indies. Nevertheless, it was obliged to proclaim the freedom of colonial trade, and many a bold spirit slipped in through the sullenly opened door.

The government of the great Marshal Daendels, the "Napoleon of the Indies" (I808-18II), and the period of the English occupation under Sir Stamford Raffles and Lord Minto (181 I-1816) were, despite all their troubles, as successful as they were beneficial to Java itself. Daendels and Raffles, pressed by necessity, were forced to alienate the last remnants of State territory, which thus passed into private hands, opening a vast field to private initiative.

The scission with Belgium, the war which followed in Holland, the enormous deficit which it left in the Dutch exchequer, and the system of forced labour designed to fill it, unhappily paralysed this first renewal of life. In I850, however, when the system of compulsory labour was condemned by public opinion, colonists reappeared in the Indies, to replace forced by free labour ; and in 1860 , when slavery had been officially suppressed, and in 1873 , the State having resolutely assumed its essential duty of protecting and educating the natives, Europeans were encouraged, and hastened to establish themselves as colonists. The distrust of the Government, hardly recovered from so many warnings, and always suspicious of covetousness in others, was at last pacified ; to-day, thanks to her climate and her inexhaustible agricultural resources, Java ranks high among the countries of Asia as the home of many Europeans.

Nearly all the Europeans in Java are Dutch. Holland, a country of merchants and sailors, and one of the wealthiest in Europe, in proportion to the numerical weakness of her population, has had no need to borrow, as it were, from other nations, either colonists, merchants, manufacturers, or money.

The Dutch own the most desirable of all colonies, having regard to their national characteristics; which explains why they are to be found in Java in far greater numbers than the English in India or the French in 
Indo-China. The European non-Dutch element (not counting European soldiers) consisted in Java and Madura, in the year 1907, of 800 Germans, whom one finds under all skies and in all latitudes, about I8o English, 274 Belgians, 146 French, and a few Italians. Java, for reasons already given and for others, such as its over-population by the natives, whence labour is very cheap, and the absence of mines of gold or silver capable of enriching the prospector by a sudden stroke of luck, has no attractions for poor Europeans. They could not perform manual work on account of the climate; and there are no gratuitous concessions of land. The French in Holland are mostly hairdressers or tailors ; presently, no doubt, the number of modistes will increase, as the Dutch are now inclined to abandon the fashion of going bareheaded in the evenings, as did the Spaniards in the Philippines, and as the women of South America do. A few Frenchmen go to Java as planters, cultivating sugar-cane or coffee on land rented on a long lease from the State, with the help of considerable capital. Such a course is the only means of making money in Java, as it is in India and Indo-China. There should be room, however, for merchants and for young electrical engineers, as many factories have need of the latter, and Holland does not herself produce them.

The stranger, of whatever nationality, or even the Dutchman newly landed in the Indies, is required within three days of his arrival to present himself to the authorities in order to establish his identity by means of his passport, and to declare whence he comes, where he is going, and his purpose; and this must be done under penalty of a five-florin fine for each day of delay, and expulsion if he shows himself evidently unwilling to comply with their formalities. I This supervision, if at

x On the pier of the Messageries Maritimes, which runs the service between Singapore and Batavia, the following notice is displayed:-

"Admission of Foreigners to the Dutch Indies.

"Every person without exception not a resident in the Dutch Indies, is required to present himself to the chief local authority 
first sight a trifle strict, is perfectly comprehensible; surrounded with powerful neighbours, and having to maintain order throughout a great empire with the least possible display of force, Holland prefers prevention rather than reprimand, and would rather examine her guests at the outset than be forced to expel them from the island if they turn out badly. Once the new-comer is accepted, the Government is extremely cordial in its relations with him, and no one receives a warmer welcome than the Dutch planter in Java.

\section{III.}

The colonist in Java, where the soil contains little subterranean wealth, is essentially an agriculturist; and the numerous factories which are building in every part of the island are only for the preparation of the true treasures of the land: coffee, tea, sugar, tobacco, quinine, \&c.

The plantation, which is often over 250 acres in extent, may pass into the colonist's hands in three different manners. He may have bought one of those great private tracts which the Company in its decline, and Daendels and Raffles in the early years of the nineteenth century, sold at the instance of a pressing need of money. Some of these estates fell into the hands of Europeans, some into the hands of the Chinese. $x$ Some

of the place where he or she finally leaves the vessel in which the voyage has been accomplished within three days of his or her arrival, in order to prove his or her identity, and to declare whence he or she has come, and with what object he or she has arrived in the Dutch Indies.

"A fine of $f_{5}$ (five florins) per day of delay is incurred in case this call is not made within the prescribed period of three days, but the total amount of such fine cannot exceed froo (roo florins)."

The same notice is displayed in the public offices of Tandjong Priok and on the tramways of Batavia. The introduction of native "servants" or boys coming from abroad is prohibited, or at least causes all kinds of difficulty.

- These territories, which are no longer capable of extension, cover an area of some $2,500,000$ acres. 
are immense tracts of untilled land, very difficult to break up for agriculture, owing to the lack of sufficient labourers; some are highly and completely cultivated, containing one or more villages, which pay rent or dues, and with regard to the owner are situated somewhat as a vassal with regard to his sovereign. On such an estate the owner may plant his sugar-cane, tobacco, or coffee, and build his factory and his house, provided that he does not seriously infringe the rights of any of the natives, who are under the protection of the State. But however large such an estate may be, the colonist does not often retain it in his own hands. When he has the chance of acquiring one of these private properties he very commonly divides it : for how can he tell whether his son will be content to live in Java after him, and continue his work, supposing that he has a family? In climates where the violent action of nature seems for ever renewing the aspect of physical objects, he does not experience any unreasonable desire of permanency; and if he owns land he rarely retains in freehold more than the plot on which his house or factory is built.

As a general thing the planter rents his land from the State. The State is the principal owner in the island; but has reserved an enormous private domain for its own exploitation, or for that of the natives with the permission of the State. The State gives the planter the land he requires as leasehold tenant (erfpachter), often for a term of seventy-five years-the duration, and more, of a life, and the time required to make a fortune-for a moderate annual rent; but in a district where labourers are rare. The native, supervised by the State, which will not allow him to be despoiled, can sell the planter only a very small portion of his own property; or may let, for twelve years or longer, a slightly smaller portion, on which the planter will build his factory in order to have it near the village, so that he may obtain plenty of inexpensive labour. It may thus often happen that the colonist is at once the tenant of the State in respect of his plantation, 


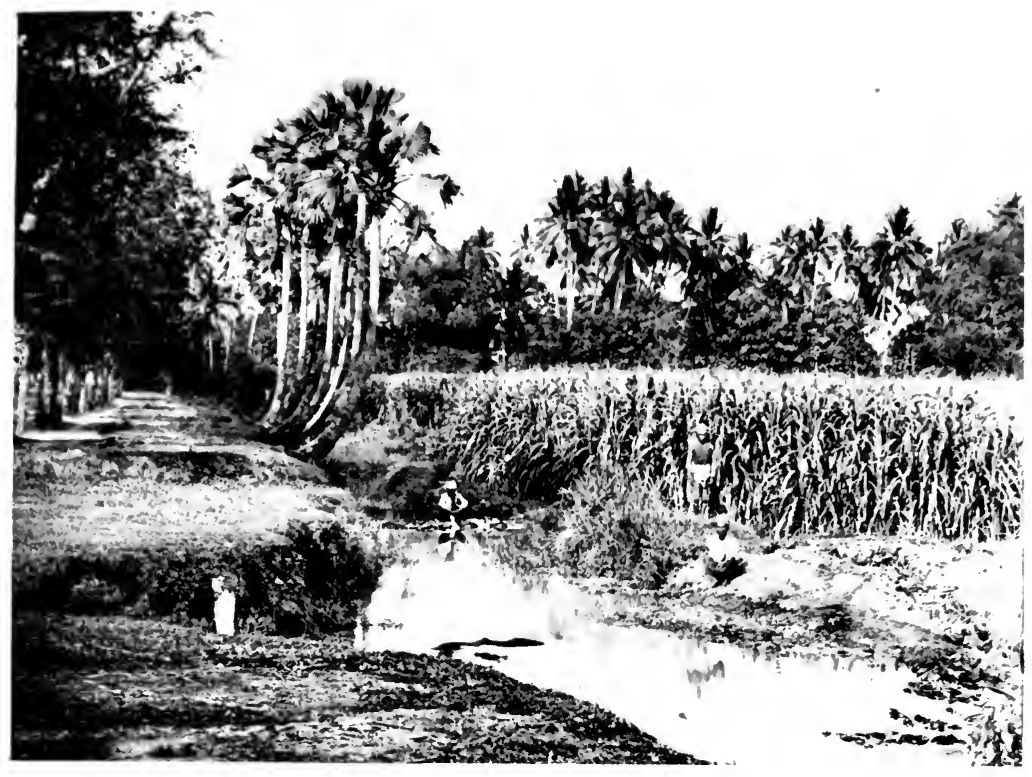

SIFAR-CANE, JAVA.

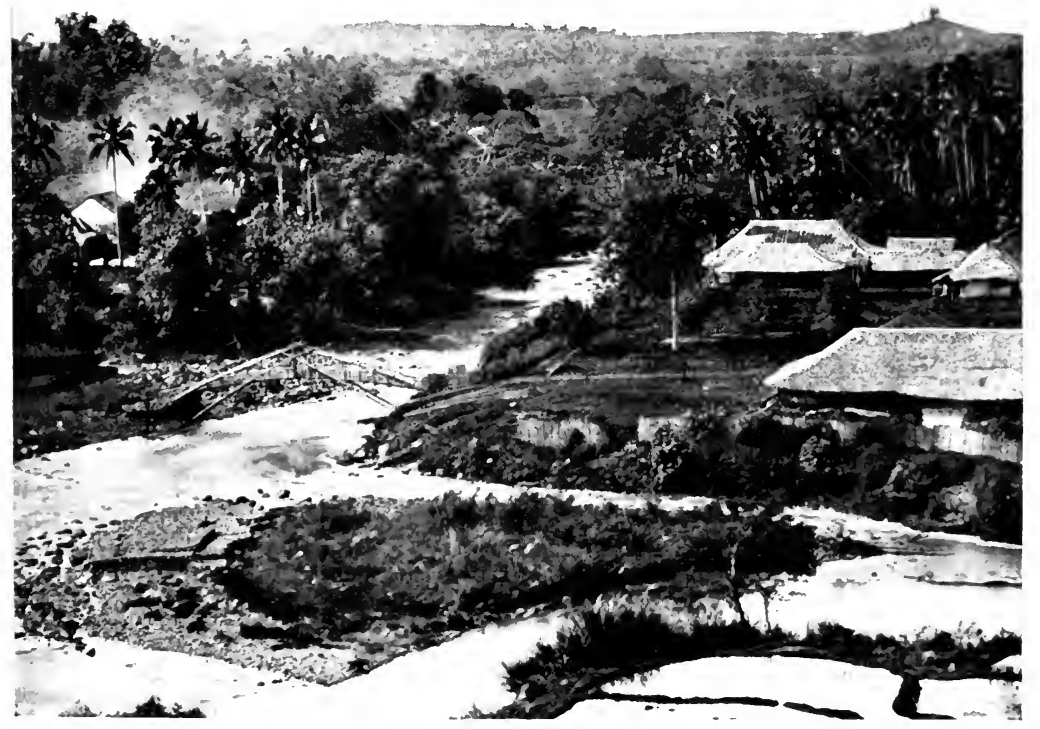



and the tenant of the native in respect of the site of his factory or godowns.

As for his dwelling-house, he tries to build it on land that is really his own; a desire easy to comprehend, and not very difficult or costly to realise.

IV.

The chief luxury of the colonial dwelling in Java, as in Indo-China, and nearly all countries of the Far East, is its setting, which nature gives for nothing. In the midst of a vegetation of magnificent trees and intertwining creepers (lianas), the planter's house is equally simple and spacious. As it is intended principally to form a shelter from the sun, and to admit as much fresh air as possible, one might almost say that it chiefly consists of a roof set upon four corner-posts; the floor, which is raised above the ground, in spite of the absence of cellars, in order to keep it comparatively free from animals and insects, $\mathbf{x}$ is covered with cement, bricks, or slabs of sandstone; or, in the wealthier houses, is flagged with marble. It is reached by an outside landing of two or more steps, which is beautified by various plants and flowers. As a rule the house has no upper floor, as such an arrangement gives the inmates the benefit of lofty

3 Various species of lizard: the geckos, or tokke (Malay toké, tekek), whose singular cry (tokké ! tokké!) astonishes the new-comer; the hemi-dactyls or margouillats, little geckos which run across the ceilings, which in Java are commonly known as tytyaks : these little reptiles keep the houses free of spiders, mosquitoes, and the softer insects. They are powerless, however, against the termites, vulgarly known as "white ants" (rayap, ani-ani), which ravage everything: timber, woodwork of all kinds, books, and clothing. One has also to beware of the attacks of ants (semut), spiders (laba-laba, kelô monggòk); centipedes (Jav. klabang, Mal. lilipan, lipan), myriapods whose bite is venomous; cockroaches (lipas, tjoro); "flying ants," termites in the winged or perfect phase (larongs), which leave their retreats in the evening and fill the air with prodigious swarms, and at sunrise strew the earth with their bodies; and other creatures. Before putting on one's boot or shoe it is always advisable to examine the interior. 
as well as spacious rooms; although in Batavia and Surabaja, under the influence of European customs, some very fine houses are now being built with upper stories.

The colonial house nearly always consists of a large central chamber or hall, which also serves as a diningroom when many guests are received. An inner gallery, running right and left, opens on the bedrooms; sometimes on an office or study for the master of the house, and a boudoir or workroom, or both in one, for the mistress. In front of this inner gallery is a large outer gallery or verandah, supported by pillars, which is open to all the winds, and is furnished with rocking-chairs, furniture devoid of upholstery, ornaments and bibelots, vases, flowers, arranged in the best possible taste. This large verandah serves as a drawing-room or receptionroom ; and parallel to this, at the back of the house, is another verandah, where the family live and take their meals on ordinary occasions. This back verandah corresponds to the chambre de ménage of the French, the stube of the Germans, the dining-room of the English, the "parlour" of the Americans.

In some wealthy houses this back verandah is replaced or supplemented by a pendoppo, a room open on all sides; covered with a separate roof, but built against the back of the main building. Formerly timber and bamboo were the materials chiefly employed in housebuilding; to-day stone is more common, or concrete (béton), or even sheet or corrugated iron.

The roof is covered with tiles, or shingles cut to the shape of slates; the ceilings of hardwood or djati (teak), or sometimes of white bamboo matting; but never of stucco or plaster; are decorated more or less, according to the fortune of the house-owner ; the walls are carefully whitened or painted; on the floor the carpet is replaced, with great advaritage, by clean, flexible matting. The kitchens, stables, coach-house, larders (or gudangs), and the bathroom (without a bath, but containing a piscina, and a large vessel of water which is poured over the 
head, and refreshes one better than anything), are in separate buildings, standing apart from the house.

Furniture is necessarily simple. Upholstered furniture is banished, as it is the certain refuge and prey of the swarming insect-life; draperies are reduced to the minimum, since as little air must be intercepted as is possible; the bedrooms are provided with a bedstead of wood or iron, which is usually provided with a wire spring-mattress, no other being impervious to insects. The bed or upper mattress is of kapok; $\mathbf{x}$ there are curtains of transparent muslin, and always a mosquito-bar of the same stuff; there is also the classic round bolster of American cloth-the "Dutch wife"which is placed between the legs, in order to diminish the perspiration; there is finally a sheet, but no coverings, except in high altitudes.

The furniture of the dining-room and the salon is either of rattan, bamboo, or hardwood, either worked or bent. The large bay-windows, the transparent curtains, and the light, flexible mattings of split bamboo or palm-leaf, are the most prominent features of the colonial house, which is the best possible refuge from the tropical heat; a refuge whereby the anæmic system derives a little comfort, while the eyes are rested by a harmonious blending of Oriental and European taste.

Everything required to furnish and decorate the house, all necessary clothing, and all, in short, that a European could possibly feel the need of in Java, may be bought in the island at a moderate cost, which prevents the necessity of taking them out from Holland, at the risk of their proving unsuitable, and possibly at great inconvenience. At Batavia one can buy all that is needed for a family containing two children-all the necessary furniture, excepting glass, crockery, lamps, \&c., for about f6o. A complete installation costs froo to firo.

It is unhappily the case that from year to year the

I A silky, lustrous down which forms around the seed of the kapok, or false cotton, or cotton-wool tree (Eriodendron anfractuosum D.C.) 
colonial house, especially in the cities, is tending to resemble more and more closely, as regards the exterior, the ordinary Dutch dwelling-house, to the great disadvantage of the simplicity of colonial life; it is also gradually losing its rustic simplicity. Planters and officials are marrying, far more frequently than of old, young women who possess, if not considerable wealth, at least considerable social position and refined tastes. They expect to find in the Indies everything that they would consider as forming a comfortable and enviable household at home. This explains why the older houses in Batavia-and notably in Surabaja, that city of progress and modernity-are being heightened by another story, the effect of which is not always happy. In such houses the inner gallery serves only as a passage; the back verandah is furnished with teak furniture frenchpolished in the modern style: little tables, bibelots, and gold-worked embroidered fabric is often more in the way than in good taste. Glass doors are slowly being replaced by light curtains; and the light matting is disappearing from the marble or imitation marble floor of the salon, which is covered by a drugget, like those to be seen in the morning-room of the provincial middle classes.

Some families, and not the least important, resist this nonsensical vanity, and the perfect simplicity of their interiors is relieved only by the reflections from a few fine Japanese or Chinese porcelains, or the soft glow of gracefully draped sarongs; and perhaps, on a massive teak sideboard, the mysterious smile of some precious Indo-Javanese statuette.

The Dutchman, who is almost as great a stickler for etiquette and formalities as the Englishman the moment he officially represents his country, and has nothing in common with the democratic ease of the French colonist in Indo-China, has succeeded in attaining, as far as every-day life is concerned, a modus vivendi full of cordial good-fellowship and agreeable liberty, which has enabled him, in spite of the climate, to live long and happily in Java. 
He profits as far as possible, in matters of clothing and food, by the instinct and experience of the native.

In the East Indian home the man is always clothed in pyjama ${ }^{1}$ trousers and a tunic of white cotton, his feet being bare in heel-less slippers; the woman is becomingly clad in the Javanese sarong, of a fine, thin cotton, held at the waist by a red girdle; a wide embroidered camisole (kabaja), and microscopic slippers which complete this summary toilet. From the æsthetic point of view the effect is rather disastrous ; the sarong, which closely moulds the round, slight figure of the little women of Java, takes regrettable liberties with the robust build and the often considerable height of the women of Holland: but the costume is relatively so cool that it allows the mistress of the house to go about her household duties without feeling the heat of the climate unduly. Formerly the women used to wear the native costume in the streets, and when visiting relations or intimate friends, and while shopping; to-day they wear it only at home; and young girls and newcomers often refuse to adopt it, replacing it by a loose peignoir trimmed with lace. Sarong and peignoir disappear in the evening, when visitors are received; when folk walk or drive on the Koningsplein at Batavia, or sally forth to take ices at the celebrated Grimm's of Surabaja: they make way for the most fashionable European toilettes; for the torments of a more or less learned coquetry, which must certainly cause many a sigh in those who submit to them after the familiar sarong or the loose peignoir. Formerly the smartest of women used to go bare-headed in the morning and evening; the plumed, feathered, complicated hat of Europe is now making its appearance, and before long amateurs of the latest fashions will be able to contem-

I Pyjamas in Java signifies simply loose trousers held up by a running-string at the waist. In Indo-China the term moresque is employed to denote: a sleeping- or resting-suit consisting of wide trousers and a full tunic with ample sleeves, made of plain or printed cotton. 
plate them in all their extravagant absurdity in Batavia or Saïgon as well as in London, Paris, or The Hague.

In their ordinary diet, however, the Dutch are still following the example of the natives; and to this fact they owe a very great deal of the success with which they resist the climate. Early in the morning the Dutchman usually partakes, at the family table, of an excellent cup of coffee, very strong, with boiling milk added; at nine comes a cold breakfast, with tea, and various native condiments which stimulate the appetite; at one he sits down before the chief meal of the day, the rijsttafel (rice table), so called from the principal dish, an enormous mountain of steamed rice, accompanied by morsels of buffalo-beef, butcher's beef, game, fish, krupuk, dendeng, ${ }^{2}$ duck's eggs cooked, salted, and pickled; mashed potatoes, scraps of fowl's liver swimming in coconut butter and seasoned with pimento; yellowish-green sauces, strongly spiced, and various peppers: in a word, a meal of so many different elements and often of such unexpected appearance that the newly-landed European is at first repelled; but the colonial mixes with his rice all or any of these ingredients, which excite his jaded palate, and thanks to them is nourished principally upon the rice, whose monotony would sicken him if he were to eat it alone. The midday meal is generally crowned by a dessert of the finest fruits of the Indies; bananas, mangoes, mangustams and shaddocks, which are sold everywhere at low prices. The dourian, greatly prized by the natives, is never admitted to European tables on account of its fetid odour; but any one who is not too disgusted by it will eat the fruit in private and at a moderate distance from inhabited places, in order not to annoy people by the horrible stench.3 At four o'clock tea is taken, with pastry or a few hors d'œuvres; at eight, a

* Squares of buffalo derma fried in oil.

2 Strips of meat dried in the sun and fried in oil ; biltong (Boer).

3 The famous Raffles had quite a particular detestation for the dourian, according to the Malay writer, Abdullah ben Abdelkader. 


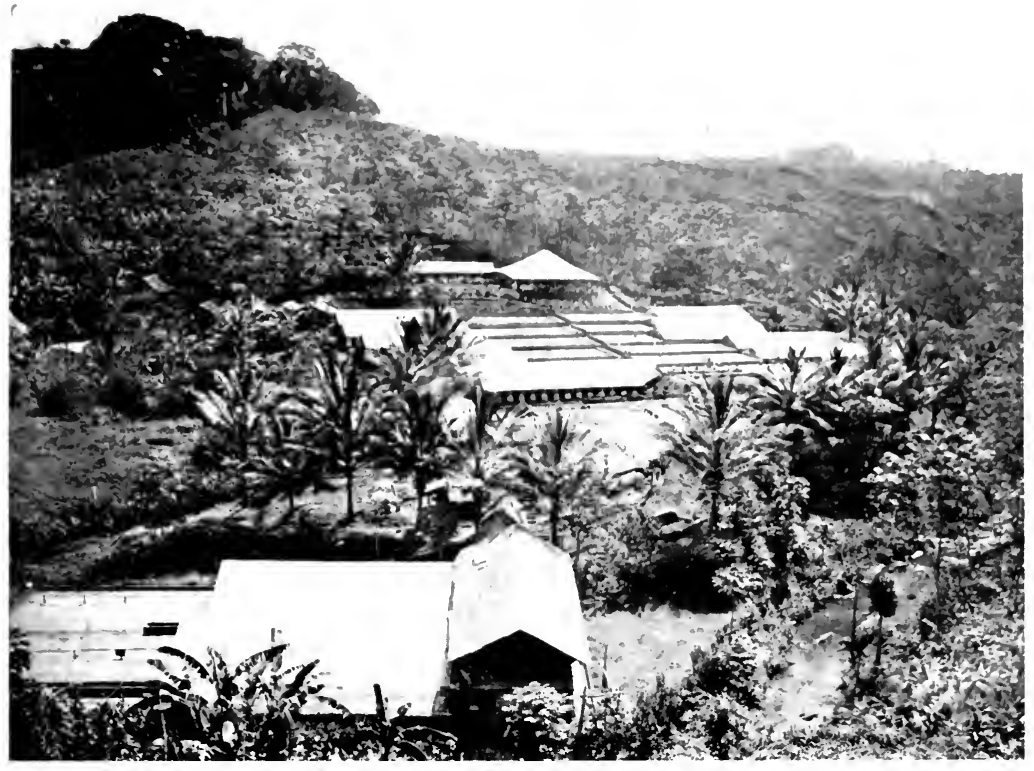

COFFEE PLANTATION, JAVA, WTTH BENGALOW AND FACTORY.

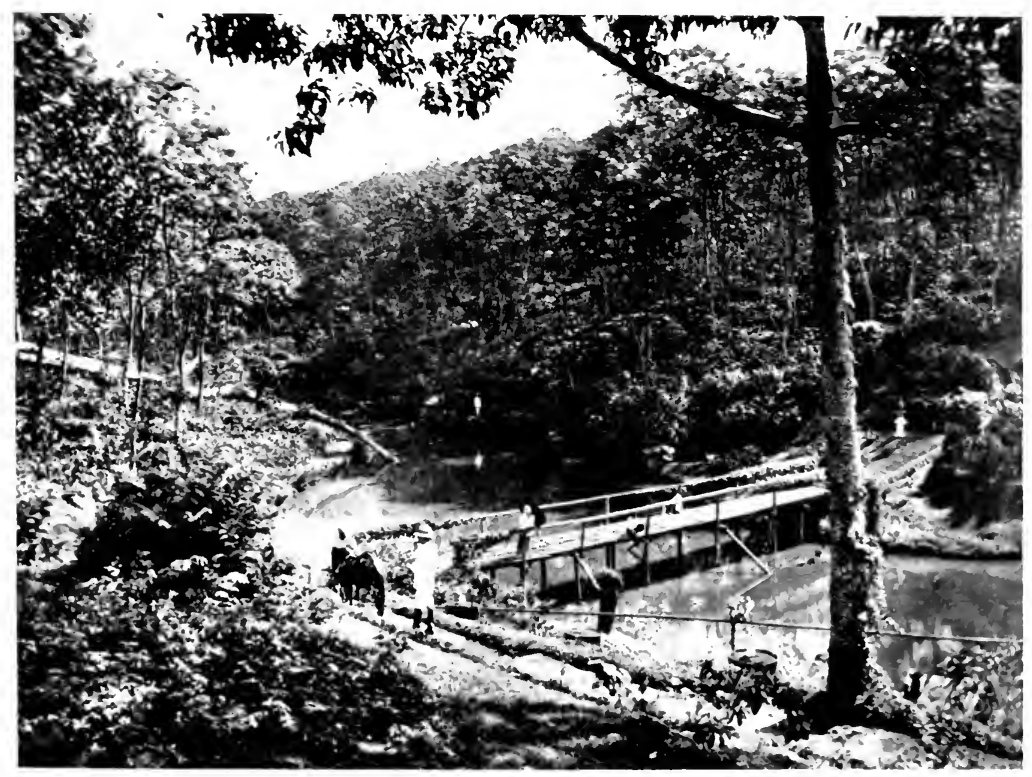



final cold collation, of which few eat very plentifully, owing to the repeated snacks and meals taken during the day.

The ordinary drink at table is water or tea; at the beginning of a meal the men take a strong dose of pahit (a bitters), which is as bad as port in its effects on the liver, and is apt to produce dysentery, which the daily use of rice prevents or alleviates.

When the Dutch colonist entertains-which he does with the most sumptuous hospitality-the dishes and wines are European; the wines of the best vintages, and the dishes perfectly prepared.

The Dutch colonist is not obliged, like the French colonist in Indo-China, to find a Chinese cook ${ }^{\mathrm{x}}$ for the Javanese woman, who is gentle, intelligent, attentive, and assimilative, very quickly learns to act as a cook, a chamber-maid, or first-class washerwoman, as she is by nature the most affectionate and attentive of wet-nurses or babus (ayahs). In a house containing one or two children, where the parents receive and maintain a certain social position, seven servants are required: butler, cook, cook's help, chamber-maids, coachman, groom, gardener, "boy-panka," 2 babus (ayahs), \&c. In the larger cities they are paid at the rate of I 2 to 15 florins per month, and expected to find their own food.3

I In Java the Chinese dislike taking service with Europeans : a Chinese cook or boy cannot be obtained for less than 15 to 25 florins per month.

$=$ Punkah coolie; the punkah or panka being a great rectangular fan suspended from the ceiling, which is swung from without by means of a cord. This device, known to the Arabs in the tenth century, and probably earlier, is now being replaced here and there by electric fans and ventilators of all kinds.

3 These servants cannot, as a rule, do anything beyond their own special duties. Thus besides the mandur (major-domo), the kokki (cook), the babu (chamber-maid, nursemaid), and the djaitt (tailor), there is the djongos (boy, valet de chambre) who is indispensable, the kusir (coachman), the tukang kuda (groom), the tukang lampu (lampboy), the tukang kebon (gardener), the tukang minotu (washing-man), \&c. The mandur has no particular duties, but is regarded as attached to the service of his master.: 
Very faithful and much attached to their employers, and especially to be trusted with young children and all that concerns them, they naturally do not possess all the virtues. The colonist, who rings for his boy to hand him an article just out of his reach, or to pick up his handkerchief, will readily accuse him of laziness ; forgetting that the torrid climate, which makes him so apathetic, has its effect upon the native also; that his own indolence, his habit (quickly acquired) of acting like a little potentate, the dimensions of his spacious dwelling, the refinements and luxuries of his life in a country as yet poorly organised from that point of view, all mean a heavy burden upon his servants, and call for a positive genius for organisation on the part of the mistress of the house. One is obliged, however, to admit a lack of thrift on the part of the Javanese "boy" who, like his brothers in Indo-China, always commences the day by begging "Madame" to make him "a little advance." It is the proper thing to grant this request, while stipulating that he shall repay these sums at the rate of 2 or 3 florins per month. This he does most scrupulously, but as he is always obtaining fresh loans he is almost always in debt, however wisely one advises him. Very sensible of good treatment, the Javanese is keenly wounded by a coarse insult or by bad treatment. Too weak to rebel openly, he is capable of revenging himself secretly in a very dangerous manner; for the dysentery and the intestinal disease which only removal from Java will cure, appears often to be the work of a vindictive servant. ${ }^{x}$

But such matters as this are the exception; an exception nearly always the result of unpardonable demands on the part of the master. The colonists complain a great deal of their domestics, because they only too often expect from them, in return for a minimum of considera-

× As to Dutch habits in Java (the house, its choice situation, arrangement, and furnishing ; every-day customs ; servants ; hygienic precautions; food ; domestic economy, \&c.), see the book by Mme. J. M. T. Catenius-Van der Meiden, Ons huis in Indië (Our House in the Indies). Samarang, 1908, $8 \mathrm{vo.}$ 
tion and justice on their own part, twenty times the zeal and obedience that one would ever dare to hope for in a European servant. "As for the virtues one demands in a servant," says Figaro to Almaviva, " does your Excellency know many masters who would be worthy to act as valets ?" More than one Javanese mandur might make the same retort to his blanda (Dutch) lord and master.

The Dutch planter is not only hospitable-in which the French planter resembles him; his hospitality is notable for a rare cordiality, delicacy, and generosity. To ensure the welfare and the happiness of his guest is a sacred duty as well as a pleasure.

His hospitality was famous for its ostentation some twenty-five or thirty years ago, when the Dutch were few in Java. Their coffee and sugar were then unrivalled on the European market; in ten or fifteen years they used to amass fortunes of many millions of florins, and delighted in sharing their prosperity with all those surrounding them : by means of sumptuous feasts, and a house open to all comers.

Those golden years have passed or are passing; and the Dutch in Java often lament the fact, concluding that they are far poorer now, that the colony is no longer bringing them in any considerable degree of wealth. The truth of the matter is very different. What is happening in all Europe is happening in Java : there is more money than ever in circulation, but it is divided amongst a much greater number of owners. There is more general wealth, but fewer large private fortunes.

Although the coffees of Java meet with a very severe competition with those of Brazil, the Malay Peninsula, \&c. ; and although the manufacture of beet sugar has caused the price of cane sugar to fall from I6 to $7 \frac{1}{2}$ florins per picul, while the establishment of a greater number of colonists, who compete one with another, has diminished the profits of each, the extensive development of agriculture and the industries which arise therefrom has resulted in a great increase of wealth all the island over.

Formerly the Dutch entertained sumptuously, but with 
simplicity and cordiality ; the mistress of the house was able to entertain all the more in that she used not, in the semi-intimacy of such receptions, to put away her comfortable sarong-kabaya; to-day there is more ceremony, and also more boredom; since there is an inevitable tendency abroad to remain at home, and not to torment oneself in the tropical heat with the corset or frock-coat in order to exchange a few stale remarks with people who are semi-strangers. As people are forced to spend less, they are less inclined to make sacrifices to the mundane existence save within calculated limits of time and expense; for which reason social life is more lethargic, and less showy than of old.

This does not mean that the social life of the East Indies is parsimonious or gloomy; it is far from being that. One might rather, indeed, reproach the Javanese Dutch for their prodigality, as one might the majority of colonists, and their tendency to accept salaries, profits, or dividends, as the easily won profits of an intangible capital: so that after leading a full and careless life they are often scarcely richer than when they commenced, or at least far poorer than they hoped; but they no longer receive except on certain days and at fixed hours; one ball a year is given instead of two; and individual entertainments are rapidly giving way to collective entertainments, which are more impersonal and more banal, given by the societies or clubs to which every one of position belongs. In every city there are clubs and associations of every kind; lecture societies, musical and choral societies, ladies' clubs, tennis clubs, and rinking clubs; and the Europeans not only patronise the theatre (comedy and light opera being the favourites) but also give amateur dramatic performances themselves. The Locomotif of Samarang, the Sourabaiasch Handelsblad, and the fava-Bode of Batavia always contain in a prominent position reports of successful and crowded performances of some lyrical or comedy company from Europe.

The colonists, in short, amuse themselves, or try to do 
so, as well as they can, in order to vary the inevitable monotony of life in an overpowering climate, and because such distractions are regarded, from the hygienic point of view, as the best preventive of neurasthenia and the unavoidable moral depression borne of a torrid atmosphere.

\section{V.}

Putting aside the rigours of the climate, and the division of the large fortunes of a former time into smaller, the real charm of life in Java is lessened, as in so many colonies, by a lack of stability, a social impermanence, which was far less obvious forty years ago. Formerly there were fewer colonists, but they lived and died often without a thought of returning to their native country. A definite decision upon this point gave existence a greater serenity; the organisation of life seemed more stable, more secure. To-day there are colonists in plenty; but although the climate of Java is far more supportable than that of India or Indo-China. both planters and officials dwell in Java only in a transitory fashion, while waiting for the pension or the fortune which will allow them to return to Europe.

In the long run they become a little weary of the full, easy existence; perhaps a little purposeless; although they regret it bitterly as soon as they return to the conventional, parsimonious, over-strenuous life of Europe. They submit, with increasing reluctance, to the necessity of parting with their children while the latter are still quite young, so that they may be educated in the mothercountry, and grow up to be useful men and good Dutchmen. Later on they fear for these children the maladies inevitable to the climate; maladies which they themselves have not escaped; the more so because their offspring have rarely the stamina of their parents. For although it is quite true that Java is a country in which the European can acclimatise himself, and can live very comfortably, he cannot reproduce his race there any better than in other tropical countries. 
Despite many arguments for and against the possibility, the union between Holland and Java seems destined to remain sterile, or to produce none but children unable to resist the climate, who often die during the first few years after birth. At first sight the remedy seemed to consist in going to Europe in search of a fine, courageous, vigorous specimen of womanhood to continue or give fresh life to one's line; the thing is easy to-day, for marriage in the colonies is nowadays getting to be regarded, even for girls of the best middle-class families, as a good settlement in life, and a species of heroism more tempting than dangerous.

So once again fine children are seen in plenty; but the mother, who has known all the luxuries of life in her native country, is so overcome by home-sickness when the time comes to send her beloved little flock overseas that it is not uncommon for the whole family to return. There is thus a constant going and coming between the mother-country and the colony; the latter consumes the energies of the former, and the former consumes the money which those energies earn as payment.

Is there danger here for Holland or for Java? Less, perhaps, than appears, if the new-comers will only benefit by the experience and the efforts of those who are leaving.

\section{VI.}

Lastly, there is perhaps one efficient remedy; a very radical remedy, it is true, but one well known to the pioneers of the Dutch power in Java : I mean the crossing of races. The question, I need hardly say, has arisen in Java as in all colonies; and although halfbreeds are more numerous in Java than in British India, and are not the object of the same biting contempt as in English society-a contempt which elsewhere tends to become modified when fortune comes to hide the mingling of races-it would be an exaggeration to say that they are looked upon with favour. Holland looks upon them sourly, and the little cliques of the "fashionable 
Dutch world" make a practice, where colonists from Java return to their native land, of investigating their pedigrees, in order to assure themselves that no brown blood contaminates their veins.

The half-breeds are accused in Java, as everywhere, of having more of the assimilative faculty than of actual intelligence, and also of having inherited the vices of both races. It would nearly always be more just, in making this latter complaint, to say that they nearly always combine the vices of two individuals; for this mingling of blood is too often the result of a brutal temperament which refuses to be guided by anything except its own desires; and the production of such halfbreeds is a kind of devolution, an evolution in a downward direction, such as that which occurs when a wealthy and sensual Oriental marries the first European girl he meets.

But it has often happened, in the Dutch Indies as elsewhere, that men of high intelligence and calm reasoning powers, having come to a full knowledge of the refined and gentle races among which they lived, have entered into closer relations with them by a marriage of which the sons have done the greatest honour to both peoples who were thus reincarnated in them. To the great name of the ethnologist Wilken, Holland could to-day add several which have helped to make her better known to the outer world; names of men whose subtle penetration and high intelligence perhaps owe more than is supposed to a Javanese or Malay mother or grandmother.

The greatest danger to be feared from the crossings of races is that the individual may add to his parent's vices a bad education, or none at all. The father, who very often wishes to break with the mother, and has no idea of encumbering himself with a child, may wish to be rid of both together, without inquiring what becomes of them; they relapse into poverty-that evil counsellor and worse schoolmistress; and being thus abandoned to the native race, they often bring to it nothing but 
a hatred of the injustice which they have suffered from.

The Dutch State has so well understood that herein lies a source of weakness and a loss of moral authority on the part of the whites that no sooner is a halfbreed child recognised by his father than it counts him, with true liberalism, as a pure-blooded Dutchman, and enregisters and educates him as such, letting no difference appear between him and his more fortunate brothers; and it then seeks to marry him to the daughter of a colonist, or an official, so as to give back to the white race what has been taken from it, and to fortify it by the admixture of a new stock.

The only great danger that may arise from ethnic cross-breeds lies in the fact that miscegenation is apt to result in marriages founded not on too great an inequality, but on too great a mental difference between the two parties. Again, the continual marriage of Dutchmen with natives would sever one of the strongest bonds which ties the European to his native land; would create a race of half-breeds so numerous that they would prefer to live apart, and after having deprived Holland of her boldest sons would finally deprive her of her colony..$^{x}$ At the present moment this solution would hardly appear desirable either for Java or for Holland, or any other colonial power; and the moral and equitable practice of mixed marriages is therefore not likely to prove more than a very ineffectual remedy for a low birth-rate, or for the excessive mortality which afflicts the European family under the tropics.

$x$ This is exactly what occurred in Brazil. Some of the great feudal nobles, after their power was broken, together with many landless gentlemen and officers, and thousands of men-at-arms, took women of fierce and warlike tribes of Indians. Natural selection, based on colour-preference, has, in the case of the aristocracy, produced a virile and energetic white race.-[TRANs.] 


\section{CHAPTER IX}

\section{THE ADMINISTRATION IN JAVA}

I. The important position of the European officials in Java.-Their restricted numbers are due to the form of government which obtains in the Dutch East Indies : the Dutch govern the native through his own chiefs.-II. Relations between the native and European administrations.-III. The hierarchy, privileges, and importance of the European official.-IV. Complaints against the officials made by colonists and natives.

I.

IF the colonists, the producers of wealth, are one of the essential factors of the prosperity of the Dutch Indies, the officials who ensure the material order without which wealth could not be created are, one might say, the regulators of wealth; regulators in many ways and in variable degrees, but whose number is more limited than one can well conceive if compared with the total of the colonial bureaucracy of France, or even with that of England; rather less than four hundred of them sufficing to govern these immense possessions.

This result is both the work of circumstances and of the political genius of Holland. When the Dutch came to the Indies, they were too weak to conquer, maintain, and overthrow by force of arms, and were desirous above all of practical results, to be obtained at the least possible expense. So soon as they had established their commercial domination, and obtained from the chiefs, whether by or against their will, a determined royalty or tribute in the produce of the country, to the exclusion of all other Europeans, they were already satisfied, without 
troubling themselves as to the manner in which these chiefs governed the natives. By miracles of concrete prudence and delicate diplomacy they succeeded in building up, in all parts of the world, a gigantic empire of which they could barely, in case of revolt, have occupied by force the twentieth part. Their system of non-interference in the government of the natives appeared to safeguard them for ever against any such attempt. By the logic of events, as soon as the enormous colonial empire of the Netherlands was brought back by the conquests of other rivals, among others the English, to proportions more normal in their very splendour, their domination over the Archipelago, which had been entirely commercial and indirect, began to grow more of a political and effective control. In Java particularly, where the Company had established its warehouses and its offices, the authority of its employees became more sensible and less discreet; to the policy of their nation they added their own, which consisted in gaining a hold upon the native in order to bring greater pressure to bear upon him. But the better officials began to foresee that the Javanese, shorn by his chiefs for the benefit of the European, whom he hardly knew, and for their own as well, and governed with a despotism and a greed that were often revolting, would finally reject the double burden. Truly enough, when the Company failed rebellion broke loose upon every hand.

The Crown, in replacing the Company, governed prudently enough at the outset; remaining, as the Company had remained, behind the chiefs and the established usages; but well aware that these chiefs, if they were not very closely supervised, would compromise its power.

This insensible and stealthy transformation of the Government into an actual protectorate was above all the work of Daendels and of Raffles. Until their time the native chiefs and princes had very vaguely been the partners, and some the very independent friends of the Dutch; but under them they became honoured officials, yet subordinate to the power of Europe. 


\section{THE ADMINISTRATION IN JAVA 191}

Daendels, sword in hand, undertook to chastise those who resisted, and to reduce the two most powerful princes, those of Surakarta and Djokjakarta, to a strict vassalage. The various regents, the inheritors of appanages, titles, wealth, prerogatives, and secular abuses, who, their royalties in kind or money once paid to Holland, considered themselves fully as independent as these two sovereigns, learned from the "Dutch Napoleon" that they held their positions not by heredity, but by royal appointment ; that they were only imposing officials, and therefore removable if they administered badly. This fundamental principle of birth once being granted, Daendels forced them to agree that henceforth they should be always appointed by Holland, but with regard to the rights of birth, and also the rights of merit, which latter might outweigh the former; that they should all take the oath of fidelity to the King at the hands of his representative, the Governor-General, and that they must administer the land according to the royal instructions, and the advice of the Resident, or European official, who would be placed beside each of them as the means of control. Daendels also endeavoured to soften the crudity of an innovation so disastrous to the dignity of the chiefs by covering them with honours; by regulating very minutely (by the decree of 1808 ) their honorific prerogatives, and questions of precedence; and by pretending, with a masterly moderation, that he wished to make them the associates of his power. In the very year when he struck this terrible blow, he united the greater part of Java in a huge conference, at which he discussed with them the needs of the country.

Raffles, for England, continued the policy of Daendels; he strengthened the measures against the princes of the Vorstenlanden, which were always disturbed, and at every turn he allowed to be seen his fixed intention of depriving the regents of all political power, and of allowing them to retain, together with their show of prestige, only the control of the local police, under strict European supervision. If they were incompetent or unworthy, he had 
no other means to ensure the security of Europeans, a little justice for the natives, and peace throughout the Indies. To the firmness of which he had already given proof he added a scrupulous respect for the questions of precedence so dear to the Javanese. The native chiefs did not dare to manifest their discontent.

But they were nevertheless terribly chagrined by so complete a downfall; when the Dutch resumed possession of their colonies in 1818 there was so much discontent abroad that the Dutch Government, which had firmly decided to benefit by the coup d'état which had been effected under the French and English domination, and was also greatly enlightened as to the moral and political value of the regents, was inclined to reproach them personally for having abandoned the cause of Holland during the last twenty years with such absolute content; yet it wished to pacify them. In 1820 their position was definitely determined by law : they remained officials, appointed, paid, and at need dismissed by the King, and were obliged to take the advice and follow the counsels of the Dutch Residents; but they remained the highest personages in the native world, and the intermediaries through whom Holland communicated with that world; moreover, they were granted titles and large pensions in order to repair their prestige.

This policy had good results, for in 1825 , at the time of the war with Java, which held in suspense the fate of the Dutch domination, the regents did not stir in aid of the Dipo Negoro.

Moreover, the Dutch Government, in order to accustom the regents to their new position, had acted with a deliberation born of reflection, and a prudent spirit of conciliation, which it has always found successful; being less anxious to decree a sudden and absurd uniformity than to obtain it in the long run. The regents were first appointed in the more submissive provinces; and the Government in almost every case took such care to respect the principles of high birth and heredity that it did not really seem that there had been any break 


\section{THE ADMINISTRATION IN JAVA 193}

with the past. Only a few individual cases betrayed the revolution accomplished. Then came the turn of other provinces; the regents of the Preangers, who were wealthy, influential, and very independent, were subjected to the general rule only after the year 1870, and with their own consent, which was obtained by skilful negotiations.

The pensions also followed the fluctuations of a skilful and entirely opportunist policy. They were large at the outset; then considerably smaller. They were larger in the case of those from whom the Government had much to fear or to hope; small in the case of regents who were not men of action. The regents of the Preangers received at the outset some $£ 3,600$ a year, or 3,600 florins per month; a sum which, added to a handsome bonus during the period of forced cultivation, often meant an assured revenue of $£ 8,000$ to $£$ ro,000 a year, which was enough to console them for a good many things. During the second generation the pensions were reduced; to-day the regents do not draw more than $I, 000$ or $I, 200$ florins per month, or about $£_{\mathrm{r}}, 000$ to $\mathrm{f}_{\mathrm{r}, 200}$ per annum, and the bonus is reduced to $£ 320$ or $£ 400$. Only one regent is still drawing $£_{3}, 600$; the regent of $\mathrm{Tj}$ jiandjur, $\mathbf{x}$ who is a proud and intelligent individual of great influence.

Enviable distinctions have also been established among the regents by means of various titles which have been conferred upon them, and which vary with their merits. The most modest regents are Raden Tumenggung; next in rank comes the title of Raden Adipati; finally Pangeran or Prince-a title which the Dutch have only conferred once in twenty years, for exceptional services, and which carries with it a very great prestige. At the outset the regents, from the heights of their hereditary titles, affected a certain disdain for this innovation, but to-day they are highly prized. ${ }^{2}$

- Or Tandyur.

2 A list of the numerous native titles and their meaning will be found in L. W. C. Van den Berg's De inlandsche rangen en titels op fava en Madoera, 2nd ed. (The Hague, 1902, large 8vo). 
Finally, having bridled the regents with the bridles of money and vanity, the Dutch still hold them by fear. The son of a regent, if he be incapable or evilly disposed, is deliberately removed from the succession, and may be replaced either by a brother or a close relation, which flatters the wholly aristocratic prejudices of Javanese, or-and this upsets them not a little-by a petty noble or a plebeian, who has won his spurs during his career, has proved himself, and by merit alone is sometimes raised from the rank of mantri to that of regent. The mantri is more feared than any; and the appointment of one seems so scandalous to the regents that the dread of it incites them to prove themselves possessed of a certain amount of administrative zeal.

\section{II.}

To-day all Java is ruled by a double system of administration-European and native-the two being juxtaposed, or one might say superimposed. Every province or Residency has, at its head, a regent, who governs alone in the eyes of the natives, with whom he alone has direct relations, according to their religious or political customs - their adat. This regent cuts a great figure; he holds a kind of court, boasts of a golden parasol, and presides at assemblies; but beside him is always the European Resident, whose part should be solely that of counsellor, and who, by an ingenious fiction, unobtrusively holds the actual power.

The Resident is, in short, the "elder brother" of the regent, which allows him to enjoy the same outward consideration, always to take the right hand of the regent at all ceremonies, and, on account of the hierarchic order of the Javanese family, to give his counsel the force of an order in cases of disagreement with the "younger brother." Wherever the Dutch policy is fully applied the Resident treats the regent with brotherly regard, and endeavours to compensate him for any suppression of his individual wishes by means of honorific advantages. 
The province can do nothing without the Resident, who is, so to speak, the veiled monarch, whose activity overflows into every department : politics, justice, agriculture, education, \&c., are all equally his business ; but everything is carried out through the agency of the regent.

Subject to the Resident in the various divisions of the province are Assistant Residents, who work in conjunction with the other regents. The latter should by rights take precedence over the Assistant Residents, but in reality the latter play the same part and assume the same position as the Residents, and in his province each Assistant has the same extensive powers as the Resident, and need not refer to the latter.

Below the Residencies and Assistant Residencies in importance are the districts; each district capital containing a native wedono, or a sort of prefect, who is under the supervision of a Dutch "comptroller." The various portions of the district are governed by assistant wedonos of the first or second class, who are under the eye of probationary comptrollers. Every native chief, of whatever degree, is aided in his task by a mantri; a probationary native official, who generally comes of the nobility, and is often the younger son of a regent, and is in this manner broken in to the conduct of business and serves an apprenticeship to his career. The mantri lives in the house of the chief, must obey his orders implicitly, and is usually destined to some special service-irrigation, coffee, opium, the police, teaching, \&c.

At the base of the system is the lura (Dutch spelling loerah), the mayor or chief or headman of the kampong or dessa; the only official who is elected by those under his administration. His appointment, however, can be annulled by the European comptroller if he is incapable, an opium-smoker, or subject to any serious infirmity which is likely to diminish his reputation or his activity.

At the summit of the pyramid is the Governor-General of the Dutch East Indies, who is appointed by the Sovereign, and is himself almost a king in his own domain, so great are his discretionary powers. $\mathrm{He}$ is 
obliged to apply the law voted by the Dutch Chambers affecting the colony, as well as royal decrees, but he may at need amend, complete, or hold them back by the promulgation of orders. $\mathrm{He}$ is commander-in-chief of the army and the naval forces; supreme comptroller, in the last resort, of every branch of the administration; he declares war or makes peace with native princes; has the rights of pardon and amnesty; appoints candidates to all civil or military employments, whether European or native ; signs foreigners' permits or passports, or decrees of expulsion from the island; and for the last forty years has undertaken to protect, develop, and slowly to emancipate the native masses. This omnipotent personage, who unites in his own person the executive and (in certain cases) the legislative power, is limited in the exercise of his powers only by the Council of the Indies, except that the Sovereign has the power to call upon him to retire, and the Chambers can impeach him if his rule appear unsatisfactory.

The Council of the Indies (Raad van NederlandschIndië), composed of a vice-president and four members, is, after the Governor-General, and in conjunction with him, the highest expression of the European power in the colony. Although in certain cases prescribed by the law the Governor is obliged to follow the advice of the Council, the latter has in general only a consultative power; the Governor, who is solely responsible to the Sovereign and the Chambers, may dispense with its advice.

The Governor-General has under his authority five directors, or ministers in a small way, entrusted respectively with the departments of Justice, Finances, Public Works, the Marine, and the Army. The meeting of these directors in Council assists him to deal with the various affairs in each department. It often happens that one of these directors is united by close family ties to the Governor-General, which sometimes gives rise to complaints of nepotism; but the selections are nearly always so happy as to be justified by the merits of the director selected. Beneath the Governor and his Secre- 


\section{THE ADMINISTRATION IN JAVA 197}

tariat-General, on whom their future depends, are the active officials of the system : the Residents, Assistant Residents, with their secretary-comptrollers and probationary comptrollers, an official whose equivalent we should seek in vain elsewhere-the "adviser" or counsellor for native affairs (Adviseur voor Inlandsche Zaken), ${ }^{\mathrm{x}}$ and philological and archæological officials, of whom we shall speak further on.

After its long period of sometimes necessary inertia, the Dutch Government began to realise that three-fourths of the revolts which broke out among the natives had their source less in regrettable examples of injustice than in instances of tactlessness and indifference on the part of Europeans who were absolutely ignorant of the beliefs, traditions, and legitimate susceptibilities of the natives. The most costly and bloody of these misunderstandings was the rebellion of Dipo Negoro, who, it seems, was unendurably exasperated by the insulting behaviour of an incompetent Resident, whence followed the Javanese War.

The State also began to realise the value of a knowledge of native idioms to its officials, and became aware of the gratuitous labours of those who had studied them; such as the long research of Kern, in Sanscrit and the comparative philology of the languages of the Indian Archipelago; of Roorda van Eysinga, Grashuis, J. Pijnappel, Von Dewal, H. Neubronner van der Tunk in Malay; of Cornets de Groot, J. F. C. Gericke, Roorda, Vreede, Poensen, in Javanese; of Matthes in Macassar and Bugi; and of many more. In 1878 , accordingly, it appointed officials to study the languages of the Dutch East Indian Archipelago, ${ }^{2}$ selected from among the doctors in the philosophy and letters of the East Indian Archipelago,3 who had obtained their degrees

- There is also a counsellor for Arab affairs (Adviseur voor Arabisclie Zaken). To-day the honorary holder of the post is an Arab, Seyyid Ousman bin Abdullah bin Akiel bin Yakya Alawi.

- Ambtenaren voor de broefening der Indische talen.

${ }^{3}$ Doctoren in de taal-en letterkunde van den Oost-Indischen archipel. 
at the University of Leyden. It assigned to each, with an honorific title and excellent pay-from $£ 300$ to $f_{\mathrm{I}}, 000$ a year with an annual increase of $£ 48$ for beginners-a definite section of the territory of the East Indies, with instructions to gain a perfect knowledge of its language, institutions, manners and customs; to compile a dictionary of the language, write its history and make known its beliefs and aspirations. They were given seven years of profound and peaceful study (but could obtain an extension of time) in which to produce a work from which all would benefit. ${ }^{x}$ To this foundation, so admirable in its intelligent utilitarianism, we owe a large number of manuals or scientific works, which have made the vast Netherlands Indies a country known to its governors as few are known. The general scope and the reputation of this work has crossed the bounds of the colony, and has given Dutch philologists, archæologists, and historians a high rank in the world of scholarship. It would have given them a very different rank had they written in an idiom better known than Dutch. Their ardent patriotism has led them always to use their mothertongue. Honourable as the motive is, one can but regret their decision in the interests of universal science. It is also to be regretted that other countries are ignorant of this enterprise, and of the scholars who place the highest and most disinterested culture at the service of the most direct and practical utilitarianism.

The adviser combines with the technical knowledge of the official philologist a political rôle which gives a still higher value to his knowledge: knowing the native mind through and through, it is his advice that is requested in all reforms of real importance, in order that the obstacles which might be encountered may be foreseen. $\mathrm{He}$ is the moral bond between the aristocratic native, whose aspirations he knows by intuition or

- Among these official linguists and archæologists the muchlamented Dr. J. L. A. Brandes (1857-1905), whose remarkable and uninterrupted work did the greatest credit to the scheme, deserves especial mention. 


\section{THE ADMINISTRATION IN JAVA 199}

divination better than any one, and the European Power, which wishes to understand them, nearly always realises them as far as possible, and at least endeavours to avoid any conflict.

When the official selected is able to play his part to the full, he is able, in spite of his purely consultative attitude, to render the very greatest services to the two parties. When the adviser is a scholar as universally recognised as Dr. C. Snouck Hurgronje, to-day Professor of Arabic in the University of Leyden, with his fundamental knowledge of Islam and its various aspects throughout the Archipelago, we can understand what weight his advice must have with the Dutch Government concerning the difficult handling of the Mahomedan masses. ${ }^{x}$

It is very regrettable that we Frenchmen, who are always having misunderstandings with the natives of our colonies, have no scholars of real repute to use their knowledge for the benefit of present realities, nor an administration sufficiently liberal to admit that the lucid and disinterested ideas of these supposed theorists might be capable of furnishing the basis of a wise and conciliatory policy.

III.

Holland asks much of her European officials, and also gives them much; and enables them to cut a worthy figure beside their luxury-loving "younger brothers," the native officials.

The Governor-General draws a salary of over $\oint_{14}, 000$, with certain allowances for the expense of public appearances, \&c., a palace at Weltevreden and another at Buitenzorg. At Tjipanas, on one of the spurs of Gedei, at a height of 5,700 feet, in an ideal climate, where the thermometer falls in the morning to $50^{\circ}$ and rarely exceeds $71^{\circ}$ even at midday, he has a country

$\therefore$ Dr. G. A. T. Hagen, an official philologist, has replaced Dr. Snouck Hurgronje as "adviser." 
pleasure-house in a great English park, in which the most magnificent vegetation of the tropics are mingled with the trees of the north : pines, cypress, chestnuts, oaks. His household retinue, although simplified on account of his own personal simplicity of taste, is semi-royal as regards the etiquette which obtains.

The members of the Council of the Indies draw over $£ 3,000$; the Residents from $f_{\mathrm{I}, 000}$ to $£ \mathrm{I}, 800$, according to rank; Assistant Residents from $£ 720$ to $£ \mathrm{I}, 000$; and comptrollers from $£ 360$ to $£ 480$. All are provided with houses, which in the case of the Residents and Assistant Residents are often princely dwellings. The pensions of these officials, after twentyfive years of service, amount to half their salaries. We must remember, however, that these officials have to furnish the interior of their houses, and that in a luxurious fashion; they must keep up a considerable household, so that it is hardly possible for them to economise : lastly, they can obtain leave only once in ten years, and while it lasts can only draw one-third of their pay.

Such advantages as the service possesses are as a rule thoroughly deserved, having regard to the serious preparation which these officials undergo, and the scrupulous system of selection of which they are the outcome.

From the day when Holland resolved to organise her colonial empire in place of exploiting it, as she had previously done, she endeavoured to employ the most carefully trained and most irreproachable class of agents.

In 1864, that a class of officials might be available who should be fully worthy of their mission, a Royal Preparatory College was founded at Leyden, having at its head the most eminent directors. Fully persuaded that uniformity in training is almost invariably a certain if unconscious means of retrogression, the Government did not make it compulsory for candidates to pass through the College; it was enough that they could meet the demands of an annual competitive examina- 


\section{THE ADMINISTRATION IN JAVA 201}

tion. The Municipal Institute of Delft competed so successfully with the Royal College that the State shortly abandoned the somewhat onerous and, to its thinking, equally useless luxury of a special Colonial College.

The Institute of Delft was too practical and commonplace for some, and suffered in its turn from the competition of the University of Leyden. It has now disappeared, and it is the Faculty of Philosophy of the said University alone that now and henceforth instructs the student in Chinese, Arabic, Turkish, Persian, Javanese, Malay, Madurese, the Old Javanese or Kawi, and the various dialects of the isles of Sunda; the comparative grammars of the languages of the islands of the Archipelago; also ethnography, geography, Colonial history, and the laws, religion, and civilisation of the Mahomedans, which subjects are all essential to any one wishing to reach the true mentality of these races. Nothing, as we see, has been forgotten that is likely to make of the student a true scholar, and a man as well fitted as possible to his future task. The professors, who are ex-administrators, ex-missionaries, or retired official scholars, who have passed their lives in the Indian Archipelago, combine a consummate practical experience with an often remarkable degree of pure scholarship. The knowledge of native tongues and institutions is a point the more firmly insisted upon because of the Government's conviction that without a knowledge of his language there can never be a real understanding between the native and the European.

Every year the Colonial Minister ascertains the number of places vacant in the Indies; and every year there is a competitive examination known as the Grand Examination of Officials (Groot-ambtevaars-examen), which is held simultaneously in The Hague and in Batavia. No agent of the Government in the Indian Archipelago, excepting the Governor-General, the President of the High Court, and two or three others, whose nomination is left to the royal initiative, can 
evade this examination, which ensures in all a serious weight of scholarship and knowledge.

Those who do well in the examinations are placed at the disposal of the Colonial Minister, who, having provided them with the expenses of the voyage, places them at the disposal of the Governor-General, who appoints them, according to requirements, to obscure corners of the Archipelago, in order to judge of their quality. There at once they are face to face with innumerable duties and responsibilities, for the comptroller, as well as the Resident, although within narrower limits, is responsible for everything: justice, police, agriculture, public works, the protection of natives, the requirements of the colonists in the matter of labour and irrigation-all depends on him and his decisions; he is at once a public official, an administrator, and a general inspector; he brings to all a convinced, serious enthusiasm, a slow and tenacious activity, and a continuous application which sometimes takes the form of a somewhat irritating and oppressive authoritativeness. No one has a finer sense of his duties than the Dutch official, nor performs them, as a rule, more scrupulously.

\section{IV.}

Yet this ideal official gives rise to more than one protest. The colonists reproach him with his attitude on the native question: complaining that under the pretext of protecting the natives, whose existence has only been a matter of interest to the State during the last forty years, he assumes an attitude towards them, the planters, which is only too often that of a suspicious busybody, as though he saw in them the born enemies and the spoliators of the Javanese. The native aristocracy, on the other hand, complain that in his uncontrollable activity he has encroached upon the limited powers of local administration which were left to them by the decree of 1820 , and that he does as 


\section{THE ADMINISTRATION IN JAVA 203}

little as he can to encourage the Javanese to obtain an education, lest he should be forced to allow them greater initiative, and, as a consequence, gradually to make way for them. They complain that at heart he thinks more of domesticating than of uplifting them.

One undeniable fact is that the administrative staffs, the dimensions of which were enormously enlarged at the time when Van den Bosch introduced his system, have never since been reduced to the normal, as each official has been unwilling to sacrifice his place, and has been quite ready to create new duties rather than abandon his ancient rights. Now the necessity of educating the natives, together with the Achinese War, has so enlarged the budget during the last three years that its equilibrium has at last been lost. Many thoughtful people, without being extreme "indigenophiles," are of opinion that it would be both politic and financially sound gradually to reduce the European staff for the benefit of the younger generation which seems so anxious to be placed in a position of responsibility, and to obtain responsible tasks of any kind to fulfil. The finances of the colony would gain by such a step; the natives would regain a little of that spirit of initiative which is often denied them, and yet is discouraged the moment it appears, for fear of further claims. By reducing the Residencies from twenty to seventeen since I900, the Government appears to have taken this view of matters, and to have entered upon this policy with determination. 


\section{CHAPTER X}

\section{THE PRODUCTS OF JAVA}

I. The various phases of the economic history of Java under Dutch rule.-II. The Van den Bosch or "forced cultivation" system.-III. The help given by the State to free labour. The Botanical Institute at Buitenzorg.-IV. Native property in land.-V. Native crops : rice, coco-palms, areca- and betelnuts.-VI. Bamboo; bamboo hats.

I.

THE economic history of Java covers many fluctuating phases corresponding to the fluctuating policies of Holland.

From the beginning of Dutch trade with the East to the failure of the Company of Commerce (I796) the Dutch practised a policy of economic realisation and administrative abstention. They busied themselves in obtaining the exclusive monopoly of certain merchandise whose production was strictly limited, and in drawing royalties in kind calculated as much on the profit they counted upon making as upon the facility of extracting it from the soil; and that was their whole policy.

The means of cultivation, the improvements which might be introduced, the method of collecting the royalties-the fate of the native, in short-appeared to interest them least of all.

With the advent of the Government of the Crown matters changed; at the outset, we must admit, for economic rather than for moral reasons.

Holland, in slowly substituting her rule for that of 
the native chiefs, intended to inherit after them, and often with them to profit by the abuses by which they lived : taxes of every kind and forced labour or corvécs: and replaced them as the chief owner of the soil.

Anxious, however, not to excite revolts by inopportune exactions, the Dutch Government endeavoured to regularise her demands in a stable fashion, and in one as far as possible equitable.

Matters were pressing, for the price of the spices which Holland had hitherto drawn from the Indies had been lowered by competition, and her revenue had been greatly decreased accordingly. As for rice, she had little more to hope from it, either in Java or in other parts of the Archipelago, as its selling price was low and its transport costly.

The total evaluation of the wealth of Java demanded a considerable time, especially where a reflective people like the Dutch was concerned. Consequently it was not they who realised the desirable innovation; this was reserved for the English and for Raffles, who, following the model of the English colonies, replaced the payment of royalties in kind, which were always variable, by the payment of a land tax based upon the value of the soil, of which half, two-thirds or a fifth was payable in kind, according to the aforesaid value. The natives lent themselves to this innovation without difficulty. If this tax had not only too often been trebled by the exactions of the native chiefs, it would doubtless have seemed reasonable enough to the natives. In $18 \mathrm{I} 8$, when Holland recovered the Dutch Indies, she retained the land tax, but ensured a better distribution of it by an attempt at a survey which was completed in 1874. In I827 she decided that when the land tax should exceed ro florins a third only should be paid in kind, and the remaining two-thirds in gold or silver.

Daendels had had the welfare of Java at heart long before Raffles, and in his mind it was inseparable from the welfare of the natives. He, however, thought of the soil before the inhabitants, and gave his attention to the 
matter of corvées, less to reduce them than to systematise them, and employ them in a direction which should be utilitarian and profitable for all. Persuaded that the absence of communications was one of the causes of the economic stagnation of Java, the "Iron Marshal" forced the natives, many of whom succumbed, to construct the magnificent road which runs from Anjer, the western point of the island, to Bunjuwąngi, its eastern extremity. In less than two years he succeeded in constructing eight hundred miles of a magnificent high-road with a double causeway: one for wagons and cattle, the other for riders and lighter vehicles; a road which is still the admiration of all foreigners, and which, in the end, has been copied throughout the island. This road, which was of the highest economic and strategic importance, was built by the most despotic methods, each dessa being forced to construct, within a determined period, a certain portion of the road. If its task was not completed by the day prescribed, the chiefs of the village, who were held responsible, were hung by Daendels' order. One can imagine the cost of that road in human lives and in every kind of iniquity. This pitiless genius, who was persuaded that the colonies should be a source of revenue to the mother-country, that their welfare must result from the increased value of the soil, and that the Javanese, in their smiling apathy, would never attempt to plant or to earn beyond their daily needs unless compelled to do so, nor cultivate more remunerative crops than rice, inaugurated the system of "forced crops," or compulsory cultivation, by decreeing that every Javanese village about which the soil was favourable to coffee should cultivate a regulation quantity-one thousand trees per family. Two-fifths of the crop was to enter the warehouses of the Government, under penalty of a heavy fine, equivalent to its value; the three-fifths remaining belonged to the cultivators, who sold them to the Government at a price established according to the market values, and of course always far inferior to the real value. The rule of Daendels was not long enough 
to allow him to complete his experiences of agriculture. The first harvests fell into the hands of the Government only on the coast, where it was possible to supervise them ; but there, too, the coffee was of indifferent quality. In the interior, owing to the lack of transport, or on account of smuggling, it was sold at ridiculous prices. The natives profited by the English domination by returning to the cultivation of rice, which at least would always assure them of a living.

The Dutch, upon their return to Java, resumed the "landrente" and corvées instead of the high-handed proceedings of Daendels, and until 1824 managed to draw a sufficient revenue. But at this time, while the European administrative system which they had been slowly installing in the island was a great burden on the budget, the free labour of the scantily encouraged colonists had not conduced to a flow of capital from Holland. Deficits and loans commenced. In I833 the colony was in debt, and the coffers of Holland were absolutely empty at the end of the war of secession with Belgium. General Count Van den Bosch presented himself, with an offer to relieve the budget and fill the coffers. $\mathrm{He}$ was given a free hand, and installed in the East Indies the "system of forced cultures" (Cultuurstelsel, or op hoog gezag ingevoerde kulturen), which at one moment was the glory of his name, and afterwards became his disgrace. His utilitarian genius, a trifle more bureaucratic than that of Daendels, was almost equal to that of the latter ; he had the same lucidity and the same unconscious immorality of opinion. As Governor-General from 1830 to 1834 , and from 1834 to 1839 as Colonial Minister, Van den Bosch disposed of the fate of the Dutch East Indies, and in spite of the highest intentions, his system was really one of regulated tribute-taking.

II.

To force the native to cultivate something more than rice, Van den Bosch took from each, under the pretext 
of replacing the "landrente," a fifth part of his land. The native owed a variable number of days of compulsory labour, or corvée, to the State. Sometimes the authorities went so far as to demand the maximum of sixty days per person, which he was forced to devote to cultivating "rich" crops for the benefit of the Government: sugar, coffee, pepper, indigo, tea, tobacco; and these crops he had to cultivate on the land which had been taken from him. The State thus benefited twice over, and without expending much energy, for it leased its lands and those subject to the corvée to contractors who undertook to feed the workers and pay the administration a fixed price in advance for the crop.

If the contractor did not lose by this arrangement, one can imagine what the State made by it, especially as it decided, in order to draw a double profit, not to substitute compulsory crops for the "landrente," but to levy both together. A veritable rain of gold fell upon Holland from the Indies. Every year the budget showed a credit balance of $30,000,000$ florins $\left(f_{2}, 500,000\right)$, which went to swell the coffers of Holland, filling the deficit left by the Belgian War, and helping to pay for important public works, and to constitute a reserve fund. The shareholders spoke of nothing but of their saviour, Van den Bosch. In twelve years nearly 2,000,000,000 florins ( $\left.f_{1} 66,000,000\right)$ was extracted from the colony by the most scandalous system of spoliation.

The natives did not rebel, for their adat, with their petty princelets, had accustomed them to all kinds of extortions, and Van den Bosch had the art of winning over the chiefs to this legal spoliation, interesting them in it by means of a large bonus on the crops of those under their administration. The latter suffered cruelly. Although they had been promised that the land tax should be repealed, they were forced to pay it after all; although a fifth of their land had been taken from them, they gradually saw the rest taken also as soon as it was made fit for cultivation. For their paddy-fields they were left only tracts of land so far from their villages that the 
continual corvées left them barely the time to sow the crop. The contractors fed them not at all, or badly; they were obliged to sell their buffalo, and to go into debt, and they were always struggling to cultivate those remunerative crops which for them meant nothing but poverty and ruin. But already authoritative voices, even in Holland, were raised in their favour. The Liberal Party, having at its head men of action such as Fransen van de Putte, writers like Veth and Van den Lith, loudly expressed its indignation that a moral and supposedly civilised people should, in the nineteenth century, condemn another to compulsory labour, and steal its lands and its money, without even using the latter to ameliorate its lot or to educate it. An ex-official, who had spent his life in the East Indies, Multatuli (Eduard Douwes Dekker), in his Max Havelaar, had eloquently pleaded the cause of the natives with the people of Holland. The book made a great sensation in. Holland, and even in Europe. The struggle was greatly embittered, for the shareholders fought for their dividends, and the State to balance its budget; but the conscience of the people, already awakened, was stunned by a new disaster. Van den Bosch, in order to prevent all chance of rebellion, had wished to crown his work by building a system of fortifications at Ambarawa, and around Samarang and Surabaja. The corvées impressed for that purpose in 1849 prevented the natives from attending to their rice-fields, and in the east of the island a terrible famine occurred : the latest of many since the organisation of the system of compulsory crops. Nearly half a million natives died. Pastor Van Hoëvell, who had lived in the Indies, placed the matter once again before Parliament and the people, bringing to his task the most moving eloquence. The system was condemned. It was slowly disorganised, and the policy of enriching the island by means of free labour (vrije-arbeid) replaced it. Gradually the compulsory crops disappeared; the last, namely sugar, being abolished in 1890 , when the Government maintained the coffee crop only for a limited period and with a promise to 
extinguish the policy completely within a certain fixed time.

These reforms, which were due to the Liberal Party, were crowned by the agrarian law (agrarische wet) of I870, by which the State guaranteed to the natives the right of property in the soil which they themselves had cleared or cultivated; and leased all lands which remained uncultivated for a term of seventy-five years to individual tenants. The corvées (heerendiensten) were reduced to twenty and thirty-two days, according to the provinces, and were to be imposed solely for works of public utility; and by the payment of an annual royalty of I florin per head a native could remain undisturbed.

The system of Van den Bosch was extremely oppressive and despoiled the natives. It has deprived Java of enormous sums of money and of precious lives. By condemning the population for more than fourteen years to hard labour, which was also for them unjust and fruitless labour, it led to their intellectual retrogression; it was therefore, from the ethical standpoint, absolutely unpardonable. Yet we cannot forget that by this realistic sacrifice of a whole generation it transformed the island into one of the richest and most fruitful of agricultural countries. It resulted, especially in the eastern provinces, where the soil is particularly fertile, in the cultivation of crops which were infinitely more profitable than rice, which are to-day the source of welfare and comfort ; and the increased value of land throughout the island has enabled the latter to feed a population which to-day amounts to more than 29,000,000 inhabitants; while in 1813 the population numbered only $6,000,000$. Once more the truth of the famous adage is exemplified: "Woe to them that make revolutions: happy are they who inherit after them!"

The extension of free labour, and the support of Dutch capital, have brought remarkable prosperity to Java since I850; and the State, upon abandoning the principles of Van den Bosch, was moved by a spirit of salutary. reaction, and turned to the natives with a genuine 
solicitude, so that first the soil and then the native population attained their true value, to the greater profit and honour of both colony and mother-country.

\section{III.}

Since then the State has demonstrated its ardent desire to assist both colonists and natives in the intensive agricultural development which is making the fortune of Java. The Botanical Institute of Buitenzorg ('s Lands Plantentuin te Buitenzorg) is not the least happy of its efforts. This establishment, which has no rival in the world, is not merely a marvellous assemblage of all the products of the flora of the Archipelago; its object is practical as well as scientific. Beauty is only its outward form; truth and utility are its inner purpose. It comprises the Botanical Garden proper of 145 acres at Buitenzorg itself, and as annexes the experimental gardens at $\mathrm{Tjikeumeu,} \mathrm{of} \mathrm{I} 80$ acres; the mountain gardens of Tjibodas, which have a much larger area; and finally the virgin forest of Tjibodas, of 700 acres. At each of these establishments are laboratories, museums, libraries, herbaria, and collections, directed by scientists of the highest rank, from the founder of the Institute, Professor Reinwardt, of Amsterdam, to the last director, the eminent Dr. Treub. In the experimental gardens attempts at the acclimatisation of foreign plants and trees of agricultural value are carried on uninterruptedly; the degree of resistance which they offer under determined conditions is studied; experiments are made in the crossing and improvement of the flora of the country; in short, the practical value and uses of the whole flora are investigated. In the laboratories, on the other hand, are studied vegetable parasites, noxious insects, chemical manures, \&c. - all that is capable of destroying or enriching that flora. The services which these laboratories have rendered in investigating the maladies peculiar to sugar-cane, tobacco, and coffee have been so great that private individuals have built such laboratories at their 
own expense in many parts of Java, for the better guidance of their own plantations.

This Botanical Institute, so noted for its purely scientific labours as well as for its practical advice, costs the East Indies 342,400 florins a year, or $£ 29,360$, while the budget of agriculture alone amounts to 7,200,000 florins ( $₫ 600,000)$, which sum is employed in the introduction of new crops or the improvement of those already existing in Java. ${ }^{\mathrm{I}}$

The rebuilding of the Agricultural College for natives (Landbouwschool) at Buitenzorg, which was destroyed by fire in 1902, and which was attended by many sons of chiefs, future administrators of great agricultural estates, will also, by increasing the yield of the soil, and therefore the welfare of the natives, have the most desirable influence upon the improvement of the masses attached to the soil.

IV.

The system of native property in Java and Madura, on account of their vast extent, could hardly have been a uniform system. In the west and in the east the ownership of land is pre-eminently hereditary and individual, with the reservation that the owners, in relation to the State, which has succeeded to their princes, can regard themselves only as the tenants for life, who cannot be ejected or molested as long as they fulfil their obligations. In the centre of Java individual and communal property co-exist side by side; the native possessing as his individual property the plot on which his house is built, and receiving from the chief of the village, every three, four, or five years, the field which is to furnish his subsistence and that of his family. The system of collective ownership has the defect that it lends itself to injustice in the distribution of the soil, as the chief can always favour his own relations; moreover, the native feels no great enthusiasm for the land when he knows

× Concerning the Botanical Gardens of Buitenzorg see the note on p. 62. 
that in a year or two it will pass into other hands. Everywhere the Dutch Government has taken care to limit the portion of land which the native can alienate, in order to save him from being completely despoiled, whether by Europeans or the Chinese.

\section{V.}

Rice is still the most important of all crops in Java and Madura. Of the $7,460,000$ acres cultivated by the natives, $5,438,000$ acres are under rice.

The rice lands are of two kinds: the wet rice-fields, or sawahs, which are by far the more productive, and the dry fields, or tegals, which are found where running water and rains are rare. ${ }^{\mathrm{I}}$

The sawahs consist of level plots surrounded by little dykes or banks, which allow the water to be run in or off at will. If the land is sloping, that defect is remedied by disposing the fields in a succession of terraces, the water trickling from one to the other ; and by carrying such a series of terraces upwards rice may be grown as high as 3,500 feet.

The natives usually work in the sawahs at the beginning of the rainy season, when they are flooded. Having repaired the water-channels and tested the solidity of the dykes, they sow the rice in the soft mud; either in the entire ear, according to the traditional native method, or by sowing the grain by hand ; a method which results in a smaller waste of rice and a better harvest.

After the sowing the soil is flooded by day and allowed to drain at night for a period of eight or ten days. At the end of a month or six weeks, according to the soil, the spikes will already have reached a certain height.

- The Hindus have left the Javanese as an inheritance a remarkable system of irrigation, which has been still further perfected by Dutch engineers. Of this the natives make excellent use. See J. E. de Meyier, "Irrigation in Java," in the Transactions of the American Society of Civil Engineers, vol. liv., part 6 (New York, 1908, 8vo). See also Bernard, Aménagement des eaux à Fava, irrigation des rizière (Paris, 1903, 4to). 
They are then taken from the limited space in which they were confined and replanted in the sawahs in groups of two or three stems together, each group being stuck in the muddy soil at a distance of half an inch to an inch from its neighbours.

The sawahs require neither fattening nor manuring. In some districts the rice is not even thinned out or replanted, but the rice is sown in the sawahs themselves, which in this case must be very soft. As this process results in the loss of a great deal of grain, it is becoming less usual.

After the operation of replanting, the soil is successively flooded and drained every two or three days, care being taken that it is dry by the time of the harvest; and at the moment of flowering all noxious weeds must be removed and the crop protected against the depredations of birds and beasts. It is usual to replant in November or December, or at latest in January; the crop is gathered at the end of the fourth or fifth month, according to the species of rice and the altitude. The natives have a curious aversion to a June harvest; they pretend that rice gathered in that month will inevitably be the prey of some calamity, or of birds, insects, disease, \&c.

The tegals, or dry rice-fields, are first of all tilled with a plough, or patjol (a sort of Javanese spade), so as to make it thoroughly loose. It is then smoothed and cleared, and holes are made in the surface at a distance of seven or eight inches from one another. In these the rice is deposited and left to germinate, which it does with variable success. This method, employed on land newly reclaimed, gives a far smaller yield than the sawahs, as might be supposed. The rice employed is usually the mountain paddy, padi gaga (padi ladang, padi hoeman, padi tigal) or Oriza Montana Lour.

Where there is water in abundance the rice may be planted at any time of the year. Replanting and harvesting are effected stem by stem; the first with the feet in the mud, and the back bent under the burning sun. The harvest is gathered standing, as the stem is cut at a 
height of 2 feet 8 inches from the ground. Both operations are performed collectively, the whole village working in each rice-field successively, with a genuine holiday spirit. These are times impatiently anticipated by the whole dessa, and are terminated by rejoicings. In vain have the Europeans tried to teach the Javanese to mow or reap his rice; he obstinately insists upon cutting it ear by ear, according to tradition, with his little curved knife, which he handles with rare dexterity, but like a man not pressed for time. He refuses even to adopt the sickle used in Sumatra.

The rice, stacked in little bundles and dried on the spot, is then placed in a trough, where a stamp or pestle separates the grain from the straw, the latter being employed in the manufacture of fine plaits for hats of a good class. The grain is husked in primitive mills, composed of a large mortar, in which disks of iron, stone, or wood are kept moving by buffalo traction or water power.

Although the cultivation of rice demands only a limited amount of labour, the harvest is often disputed by birds, wild boar, insects, and disease; a particular enemy being a certain caterpillar, which issues from the egg when the field is dry, and gnaws the stem; or the walang sangit (Leptocorisa acuta Thumb.), which prevents the grain from forming, and ruins whole fields. The mentek (= evil spirit), a sort of rust or mildew which sears the blades, and afterwards attacks the roots, does almost as much damage. But the depredations of the tikus (mice) are worst of all.

Formerly, after the first rice harvest, the native used to attempt to obtain a second or even a third crop from the same soil, which quickly exhausted it. As a result of the advice, and even the prohibitions of the Government, they have now abandoned this practice. Now, when the rice crop is gathered, they usually sow potatoes in the sawahs, or artichokes, which spring up in two or three months. In the Preangers and in Bantam, thanks to the permanent abundance of running water, the sawahs are converted into fish-ponds. The fish reared 
or fattened in these ponds are excellent eating at the end of two or three months, and bring in a good profit.

The normal production of rice in Java is Io to $\mathbf{I 2}$ piculs per acre, the picul amounting to some r35 lbs. The rice-crop has continually improved; in I895 Java produced only 36,702 tons; in 1907 the crop amounted to 38,864 tons. In 1900, an especially fertile year, the harvest was one of 39,887 tons. Yet this great quantity of rice is still insufficient for Java, and large quantities are annually imported from Saigon and Singapore.

Maize (djagong) is also grown by the natives around their houses, but in a far less degree than rice. Its cultivation has been increasing in Madura.

Another culture-the coco-nut and the palm which bears it (kalapa)-which the native until quite recently produced only in proportion to his personal needs, is now very general throughout Java, and is the subject of a great export trade. The coco-palm grows more especially in the centre of Java, in the Residency of Kedu, where it attains a most vigorous growth, but does not require manuring, nor any particular care, as it does in Ceylon.

There is a very important local trade in the entire nuts, as both the natives and the planters appreciate the refreshing and agreeable juice of the fresh nut as a beverage. They are also employed in cookery. Again, the coco-palm is an oleaginous plant of the first rank. The oil extracted from the kernel, which is previously broken into two or three pieces and dried, when it is known as copra, is employed in the manufacture of soap, candles, \&c. ; it also yields an excellent vegetable fat (vegetaline, vegetable butter, vegetable suet, Palmine, \&c.), which is employed in making biscuits, cakes, and pastry, and is more and more rapidly replacing dairy butter in the industrial production of such articles, and in the private kitchen.

The fresh-kernel, grated and dried, is used in the preparation of dishes, pastries, cakes, \&c., in Holland, Austria, Germany, England, and the United States. The 
residue left after the extraction of oil, or copra oil-cake, is an excellent food for cattle, and is also used as a manure.

The fibrous envelope of the coco-nut furnishes, after steeping, the familiar coco-nut fibre, which is used for rope-making, in cheap brooms and scrubbing-brushes, for caulking the seams of ships, and in coco-nut fibre matting, \&c.

The exports from this source, which consist chiefly of copra, commenced in 1859, and in 1900 had attained a value for the whole of the Dutch Indies of $£ 420,000$. Java was responsible for about one-half of this amount, which was principally exported from Tjilatjap, Surabaja, and Batavia to Holland, France, and Singapore. This is one of the most important articles of trade between France and the Dutch colonies.

The areca-nut and the betel-nut are grown for local use, in order to provide sirih, which the natives are always chewing.

\section{VI.}

Another plant, which, although its cultivation demands no care, has always provided the natives with their principal building materials, the greater part of their furniture, and their kitchen utensils, is the bamboo. This has also given birth to a hat-making industry, the chief centres of which are Bantam and the Tangarang district, whose products have a wide sale in France and the United States. Created by the Chinese of Manilla, this industry now occupies sixty thousand natives. The bamboo hat, which is as flexible as the Manilla hat, has, however, the serious defect of turning yellow on exposure to the air, and it cannot be washed. In its manufacture the men cut into thin ribbons the outer skin of a certain bamboo; the women and children of the village plait in two working days a hat which sells for about 4d. Prices naturally vary with the fineness of the plait, and the European agents who buy the hats on 
the spot, with the help of Malay and Chinese assistants, distinguish as many as ten qualities. The purchases of the French and American houses have nearly doubled the prices, especially of those of exceptional quality, which sell in France to-day at from $f \mathrm{I}$ to $\mathrm{f}_{\mathrm{I}} 4 \mathrm{~s}$. These require two months of continual work. Before they are sold the brims of the hats are hemmed, and they are steeped in bisulphite of soda in order to bleach them, and dried in the sun. At one time peroxide of hydrogen was employed, but the use of bisulphite of soda was resumed, as certain Protectionist countries would not accept hats as being in the unfinished state if they happened to be of a startling whiteness.

Any hats stained by the bisulphite are dyed by the Chinese and sold to the natives; or they are sold by the manufacturers as sun-helmets, after having been placed in a metal mould and covered with white cloth. .

The perfect examples are sold to Europe and America, in zinc-lined cases containing from 1,200 to 2, roo, according to the quality. In 1900 the total exports amounted to four millions of hats, and one single house in Tangerang despatched more than thirty thousand a week.I

The French house, L. Platon, which has its headquarters at Kali-Besar (Batavia), and agents at Bordeaux, also exports a great quantity of these hats. The abundance of the bamboo, the ability of the natives, and the cheapness and quality of labour, assure a great future to this industry.

- See De Rivet's book, L'Industrie du chapeau en Équateur et au Pérou (Librairie Orientale et Américaine, Paris, E. Guilmoto). 


\section{CHAPTER XI}

\section{AGRICULTURE : VARIOUS CROPS}

I. Coffee.-II. Sugar-cane.-III. Tobacco.-IV. Tea.-V. Quinine,

VI. Indigo.-VII. Lesser crops : pepper, cinnamon, cotton, \&c.

I.

AMONG the more remunerative crops not indigenous to Java, by far the most important is coffee.

In 1699 Henricus $Z$ waardecroon imported some slips or cuttings of coffee-trees from Malabar into Java. In I706 the first crop made its appearance upon the markets of Holland, when it was welcomed to such effect that, although throughout the eighteenth century all efforts to extend the production of coffee through the centre and the east of Java were unsuccessful, yet coffee was one of the first crops to be declared compulsory by Van den Bosch.

Coffee did then spread all over Java. It is the last crop which the State has retained partially in its own hands; but its intervention in this department of agriculture has no longer the harmful character of a monopoly. The poor results obtained by the system have led to its entire abandonment in the provinces of Bantam, and the districts of Japara and Rembang, and have led to its being restricted in many others. In I 900 there were still 288,000 families cultivating $66,000,000$ trees, of which $15,246,000$ were not yet bearing, for the Government of Holland; but the latter pays them for the harvest far more generously than of old.

The free plantations contained 181,000,000 trees, of 
which about $16,000,000$ were not yet bearing; and the total area covered by the State and the free plantations was about 300,000 acres, which has since steadily increased, for 50 per cent. of the fallow land conceded upon very long lease is planted with coffee, and the State does its utmost to encourage the native to grow it on his own property, by furnishing him with seed and cuttings of Liberia coffee. The Javanese, who are unaccustomed to crops that require prolonged care, and are very badly off for tools, confine themselves to gathering the crop, and removing the coffee from the shell by shaking it in baskets. It is then delivered, at a regulation price, to Europeans who complete the preparation of the berry, and then, for a small commission, despatch it to the Government warehouses.

Coffee grows well in Java at all altitudes up to 4,000 feet; but does best between the limits of I,400 and 2,800 feet.

The principal varieties cultivated in Java are the Coffea arabica and the Coffea liberica, the latter being the better adapted to resist the attacks of the terrible Hemileia vastatrix; the Coffea maragogypa is also grown on a smaller scale, and attempts are being made to acclimatise the Coffea stenophylla from Central Africa. In view of the important part which the cultivation of coffee plays in the colony, the laboratories of Buitenzorg and the experimental gardens are busily increasing their research work with a view to attacking the parasites of the precious shrub, and to introducing the more productive and resistant varieties. The planters themselves have even founded a station at Buitenzorg which deals entirely with coffee, and they do not, as a rule, undertake the planting of coffee until they have undergone a serious course of study at the Agricultural College of Wageningen in Holland, where the department of tropical agriculture and arboriculture, together with the courses in Malay and the ethnology of the Archipelago, afford them a very excellent training for the purpose. ${ }^{\mathrm{I}}$

× The Higher Royal College of Agriculture, Horticulture and Forestry of Wageningen (Rijks hoogere Land-, Tuin- en Boshbouw- 


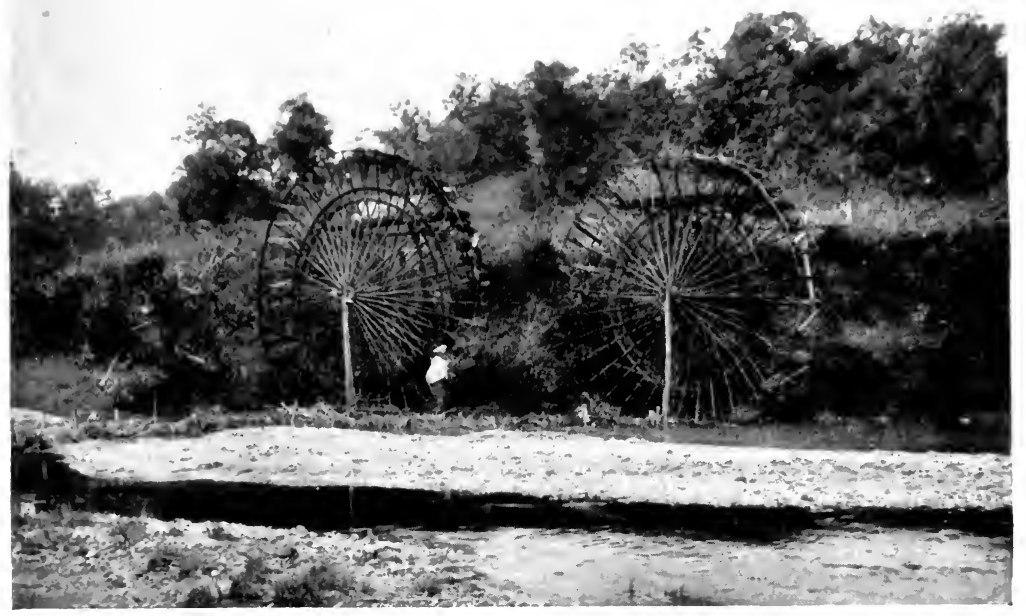

NATIVE IRRIGATION WHEELS.

(Kattan wheels, wattle paddles, bamboo buckets, wooden pipes.)

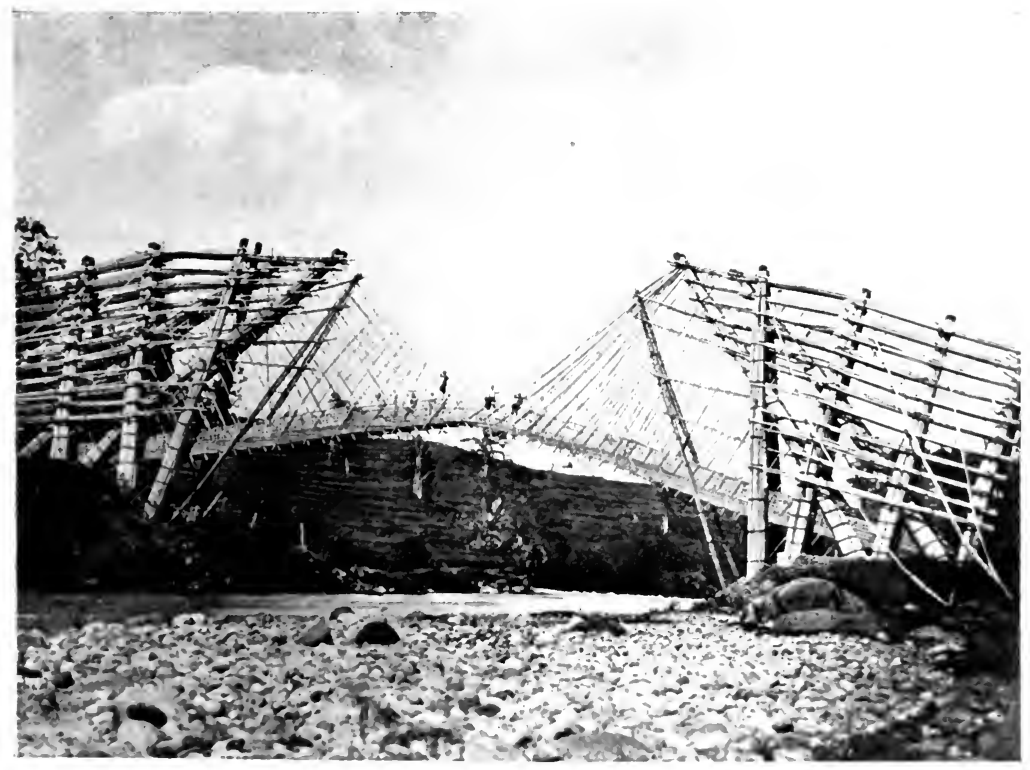





\section{AGRICULTURE: VARIOUS CROPS 221}

Liberia coffee is grown more especially on the plains; all varieties grow best on soils which contain an excess neither of clay nor of sand, are not too heavy, and are well mixed with humus.

Land for a new plantation is broken up at the beginning of the dry season. The trees-if it be forest land-may be felled or burned; in the latter case the heat of their burning increases the fertility of the soil. Even when a whole forest is cut down, care is taken to leave rows of trees as windbreaks, which protect the young shrubs from the prevailing winds. ${ }^{x}$

The land must then be thoroughly freed from harmful weeds, sometimes by ploughing, more often by the patjol, and sometimes by hand or with a curved knife (arit); when the land is sloping the trees are planted in terraces. It is especially necessary to eradicate the alangalang (Imperata arundinacea Cyr.), and to burn it, roots and all. Otherwise, even if buried in heaps at the end of the furrows, it will spring up and resume its possession of the soil in a few days.

The next step is to dig a series of pits some 2 feet deep and 2 feet wide, which are left open to the air for two months, and then filled with manure, except in the case of virgin land, which does not require it, or where it would be a matter of too great difficulty to procure it. On land thus prepared, provided the roots are not impeded by stones or too hard a soil, the young shrubs will grow with great vigour. They may advantageously be sheltered by a screen of trees, a special variety being employed for this purpose : the dadaps (Erythrine, Hypaphorus subumbrans); or the Albizzia stipulata, or

school te wageningen) educates agronomic engineers and forestry officers. It possesses a department for the training of those who intend to emigrate to the East Indies, whether in the service of the State, or that of private employers, or who wish to be able to become competent managers of plantations. See the Programma der Lessen voor 1909-19ro (Wageningen, published by van F. E. Haak, 1909, 8vo).

: For a study of coffee-planting see São Paolo du Brésil, by L. Casabona (Librairie Orientale et Américaine, E. Guilmoto). 
Albizzia molucrana, which gives an admirable shade, but is very fragile; or the Deguelia microphylla, which is inclined to grow to an excessive height. The dadap is the best of these trees. The number of these tree-shelters varies with the kind of tree employed and the altitude of the plantation; the higher it is the less need is there of shade.

From January to April, and earlier on higher ground, the seeds or berries are sown; the seed-coffee being first well washed with a mixture of water and ashes, which removes any adherent viscous matter. This operation is performed in a sort of sheltered nursery; at the end of the rainy season, in December, when the young seedlings thus obtained will be more than 12 inches in height, they are removed, with the roots well covered with earth, to the new plantation, there to be replanted. On some plantations the planters simply make use of the seedlings which spring up among the shrubs from fallen coffeeberries. All that remains to be done after the planting is to weed very carefully among the shrubs, and on lowlying lands to lift the soil carefully with the patjol once or twice a year until the fourth year. Care must also be taken to prevent the shrub from shooting up too rapidly.

Two or three years after planting the shrub begins to bear fruit; but no harvest is gathered until the fifth or sixth year, and the crop is most abundant only towards the fifteenth year. It may live forty, fifty, or sixty years longer, but its yield gradually decreases. It flowers at the commencement of the rainy season; seven or eight months later the fruit is ripe. It is of a bright red colour, which makes the plantations a very beautiful sight.

On all the important estates the coffee is to-day prepared by the modern process, which retains the aroma of the berry while giving it a good polish. The berries are freed from the husk or pod directly after the harvest, by means of revolving cylinders, which are turned by steam or water-power. The berries are then carefully washed, dried in steam drying-machines, and then freed from the 


\section{AGRICULTURE: VARIOUS CROPS 223}

last or inner husk or envelope, and winnowed to remove the broken husks.

The East Indies, next to Brazil, produce the best coffee and the largest quantity. They furnish one-fifth of the world's consumption, and the value of the harvest often amounts to $f 2,500,000$.

Coffee-planting is not what it was formerly-a certain source of wealth. Competition in all parts of the world $x$ and in the Indies themselves has resulted in a lowering of prices, and has diminished the profits by dividing them between a larger number of planters.

Coffee, moreover, is subject to a series of pests and maladies. One of these pests, the Hemileia vastatrix, has practically annihilated the coffee-plantations of Ceylon. This is an orange-coloured mould, which appears on the under side of the leaves, causing them to fall, and which blackens and kills both fruit and branches. In many cases it has destroyed large plantations in a few months. Hitherto the innumerable remedies attempted have been almost useless ; the best appears to be to smoke the tree thoroughly in order to increase its resistance to the plague.

To this plague we must add "the black blight," which blackens stems and leaves; the djamur upas, a poisonous agaric or fungus which kills the young twigs in the course of a few days; a microscopic insect which produces a disease known in Holland as aaltjesziekte, which destroys the roots, as do also two beetles, or rather their larvæ; the kuwuk, or larva of the Exopholus hypoleuca, and the uret, or larva of the Lachnostera ancylonicha; and finally the larva of an insect, known as the koffieborer or "coffee-piercer" as its name denotes: the Hylotrichus quadrupes.

On account of all these enemies to production, the cultivation of coffee is somewhat on the decrease in Java.

In 1895 the compulsory crops amounted to 318,829

s And the years of excessive over-production in Brazil, when one year's crop in San Paolo greatly exceeded the world's annual consumption, thus glutting the markets. - ['TRANs.] 
piculs (about r9,000 tons), and the yield of the free plantations 378 , 100 piculs (about 23,000 tons). In 1906 the figures were 168,343 piculs (ro,000 tons), and 318,185 piculs ( 19,500 tons); in 1907 (a particularly bad year) the State crop was 30,702 piculs (about 1,903 tons), and the "free" crop I95, II6 piculs (I2,000 tons). In I899, on the other hand, which was an excellent year for coffee, the several yields were 198,708 piculs ( 13,000 tons), and $55^{2}, 040$ piculs $(34,000$ tons). Nearly all the Java coffees are exported to Rotterdam and Amsterdam, whence they are distributed to the rest of Europe.

France, Austria, North America, and Singapore are the best buyers of Javanese coffee. ${ }^{x}$ Of the recent total of $\mathrm{I}_{5,520}$ tons, of which 4,538 belonged to the State, while 10,928 tons were "free," France received 588 tons, Austria 536, America 4,061, and Singapore 2,214.

\section{II.}

If, as is believed, sugar-cane was imported into the East Indies, it was at some fairly remote period, since it had been already acclimatised for four centuries when the Europeans landed. However, the cultivation of sugar-cane became systematic only in 1830 , when it was promoted by Van den Bosch. His system, however, was not as successful as one might have expected. The Government practically forced private persons to make sugar under somewhat onerous conditions from the compulsory crops of cane; this sugar it sold. Owing to a lack of technical knowledge and an insufficient rate of remuneration, the Government was unable to find contractors who would undertake the industrial preparation of sugar in its place, and principally for its benefit, and was forced to fall back upon a few subordinate officials and Chinese; so that its monoply was far less profitable than was anticipated, precisely on account of its stringency. The sugar industry underwent no general exten-

× Concerning coffee and other products, see Les grandes cultures dans l'île de Fava (Leyden, Brill, I909, fol.). 
sion until 1877 , when the State abandoned its monopoly to a great extent; in 1880 it abolished it altogether. From that date free labour, supported by the home capitalists, began to cover the Dutch Indies with plantations of cane, the area under cane to-day exceeding 200,000 acres. The majority of these plantations are in the north of Java.

Two unforeseen events occurred. The development in Europe of the beet-sugar industry and the disease known as sereh, produced by a parasite, caused a crisis in the sugar industry during the latter part of the nineteenth century. The beet-sugar industry caused the picul of sugar to fall from 16 florins to $7 \frac{1}{2}$; the disease devoured entire plantations. The colonists faced this double danger with much energy; two experimental stations were established in Java ${ }^{1}$ for the purpose of determining the species of cane best adapted to resist disease and those richest in sugar, and of deciding what chemical fertilisers might increase these two qualities; as a result the planters were able to produce more sugar from a ton of cane, to lower their prices, and to survive competition.

The species cultivated in Java are numerous. As the result of experiments with the Madagascar cane, and varieties from Borneo, Mauritius, and the Fijis, the black or red-brown cane of Cheribon is now commonly used; and also the white cane, which the natives prefer because it grows more profusely. Both are cultivated more particularly in the sawahs, and more rarely on dry lands, for the drainage and irrigation of cane requires a great deal of care. The cane is usually grown from shoots, which are planted in well-tilled land; although since 1887 attempts have been made to raise the cane from seed, in order to avoid weakening the adult cane from which the shoots are taken, and so decreasing its power of resisting disease. These experiments appear to have been attended with perfect success when the seed of

- These two establishments have lately been incorporated into one, named Het proefstation voor de Fava-Suikerindustrie, which is situated in Samarang. See Regeerings Almanak, 1909, vol. ii. p. 54I. 
the yellow cane of Hawai has been used. Usually the land is ploughed in March or April ; the cane is planted in July, and before planting the soil must be thoroughly watered. Both before and after planting it is indispensable, if a good harvest be desired, to fatten the soil with sulphite of ammonia and oil-cake-preferably the residue of caraway seed. At the end of ten or fourteen months in the plains, or eighteen on the uplands, the cane will have reached maturity. The cane is harvested from June to October, and the process of sugar-making commences at once; which means that the hands employed have to work, in shifts, day and night for three months. If the planter delays when once the cane is ripe the sap loses both quantity and quality. The cane may be cut or uprooted; but the precaution is first taken of cutting off the heads of the plants, in order that they may serve for a new plantation.

The cane is crushed in the neighbouring factory; the dry leaves and débris serving as fuel for the engine which works the crushing-mill. A bouw, or field of $I^{\circ} 73$ acres, yields an average of 5 tons of cane, but will sometimes produce twice as much. Crushed between rollers which are rotated by steam-power, the cane yields from 65 to 70 per cent. of its weight in sap; in an especially well-equipped factory the proportion may be as high as 80 per cent.

The sap first flows through a filter, and is then purified by saturating it with lime. It is further purified by filtering under pressure, and then boiled in a vacuum. The sugar thus obtained is dried in centrifugal separators, which fling off the molasses or crude treacle. It is then whitened by means of a fine spray of water or dry steam;

x Milk of lime is mixed with the sap to neutralise the acids in the juice ; clay, finings, and sulphurous acid may also be used to remove impurities. These coagulate, and either sink or rise to the surface. The clarified juice is run through filters-bag filters of felt, or charcoal, or capillary filters; pressure is usually employed to hasten the operation. In vacuo the sugar boils at about $150^{\circ} \mathrm{Fahr}$; ; greater heat discolours the product. When minute crystals commence to form in the vacuum, pure fresh syrup is admitted, and the resulting cake is treated in the centrifugal separators.-[TRANs.] 
then, after being dried by artificial heat or sunlight, it is packed in baskets. The molasses is treated in centrifugal separators to save the sugar still contained in it, or is distilled for the purpose of making arack, or native rum. ${ }^{x}$

As a rule, the maximum yield of the bouw, or field of 1.73 acres, is II 5 to 160 piculs of sugar; or from 4 to $5^{\circ} 6$ tons per acre. Such a result can only be obtained by means of a perfected modern equipment, which is very costly. The planters of Java, however, have not hesitated to install such plant. At the same time such machinery is not within the reach of all, so that it is not surprising that the number of factories decreases as their total output increases.

Thus in 1895 there were 195 sugar factories in Java, yielding $9,454,44 \mathrm{I}$ piculs $(586, \mathrm{I} 75$ tons); in I90 I there were 185 , yielding $13,091,000$ piculs (8II,666 tons); in 1907 there were $\mathrm{I} 77$, yielding $\mathrm{I} 8, \mathrm{I} 38,304$ piculs $(\mathrm{I}, \mathrm{I} 24,570$ tons metric).

In the year 1907-1908 the Dutch East Indies exported a total of I,I95,334 tons of sugar, of which 335,52I went to British India, while America and Hong-Kong absorbed I7I,470 and I6I,510 tons respectively. The East Indies hold the first place among sugar-producing countries; Java by itself comes immediately after Cuba.2

In addition to the European sugar industry there is also a native industry. The natives cultivate the white cane, which gives a poor yield, but requires little attention. Native sugar, which is of course an inferior product, is known as gula fawa. Certain factories in Surabaja have made the experiment of refining the native sugars in order to produce from it a white sugar. With the sap of the sugar or toddy palm, the Arenga saccharifera, the natives

× The sap of the sugar-cane undergoes very rapid fermentation once it is expelled from the cane.-[Trans.]

$=$ The Syndicate General of the sugar manufacturers of the Dutch East Indies has for fourteen years published an Annual which gives full details of their industry, and a chart showing the positions of their factories. The Annual is entitled, faarboek voor Suikerfabrikanten op Fava, 1909-10 (Amsterdam, J. H. de Bussy, I909, 8vo). 
still prepare little flat or conical cubes of brown sugar, which has a nutty flavour, and is sold very cheaply; and they prepare from the fermented sap of the same palm the alcoholic liquor known as tuwak, the abuse of which makes the Madurese native a somewhat uncertain character. This tree also yields a vegetable fibre $(d u k, i d j u k)$, which is used for making cordage and cheap carpets. They extract a rather poor sugar from the Nipa fruticans, which grows in the marshes, and whose leaves, under the name of atap, they use to thatch their houses.

\section{III.}

If tobacco is not unquestionably native in the East Indies-and the many varieties of the tobacco plant found there seem to prove that it is-it has at least become a general necessity to the native population, who smoke it rolled in a piece of maize-leaf, $\mathbf{x}$ chew it, or mix it with sirih. In Java and in the greater part of the Archipelago, and in Sumatra notably, there are, roughly speaking, two kinds of tobacco grown and two methods of cultivation. The quality of the two kinds is very different, but the cultivation of either is rapidly spreading. One kind is the subject of the native trade; the other is exported to Europe and America.

Native tobacco is grown most extensively in Kedu, Bagelein, Pasuruan, Pekalongan, Rembang, and the Preangers. It is grown in rotation with rice in the drier districts; it is not treated with any great care, either before or after it is plucked; consequently the leaf is small and the aroma displeasing to the European palate. It is dispatched into all parts of the island, and some is exported to Singapore, whence it is exported once more to such parts of the Archipelago as grow no tobacco: Amboin, Borneo, \&c.

Tobacco of the European quality is prepared by the natives, according to the methods and under the active supervision of Europeans. It is grown more especially

. As do the Brazilians, this being their form of the cigarette. $-[\mathrm{TR}$. 


\section{AGRICULTURE: VARIOUS CROPS 229}

in the centre of Java, in the Vorstenlanden and the eastern portion of the island. It is grown from the seashore up to a height of over 6,000 feet among the mountains; the best and the most easy to handle is found in those low-lying lands which are least saturated with moisture. Such lands, which from time to time are well watered by the rains, are the best of all. The first essential, in growing good tobacco, is the choice of sound seed belonging to a good variety. Formerly the kinds apparently indigenous to Java were planted, but the leaves were too small for the European trade; the Dutch variety, with larger leaves, rapidly degenerated; the Manilla variety, which in new surroundings acquired a totally different perfume and flavour, retained its flexibility, and has been largely used, though less largely than the Deli (Sumatra) tobacco. To obtain the best seed the planters surround a few fine plants with hedges, watch carefully over the ripening of the pods, which are dried in the sun, and when the capsules open the released seeds are hermetically sealed in bottles.

They are sown at once, mixed with wood ashes, in frames with adjustable tops, so that the heat and light may be regulated. The period of germination requires careful supervision; at the outset the frames must be watered twice a day, and the sun must not shine upon them save in the morning; but gradually a daily watering suffices, and they are sheltered from the sun only at midday.

In forty or fifty days the seedlings are sufficiently grown to be replanted in the open air; but each seedling is sheltered from the sun by means of a little rice-straw, or a large leaf turned backwards on its stem, and the watering is continued. At the end of a fortnight they are uncovered, and the soil around the plants is lifted and aired by means of the patjol. When they are some I 2 inches high the lower leaves are removed, and the stems are twice earthed up. Having attained their full development, the buds are nipped to prevent flowering. This is a delicate operation; if too much of the stalk be 
removed the leaves become thick and heavy; if too little, the lower leaves are starved. After this pruning process the tobacco is left to ripen for two weeks longer. If a few showers fall about this period, so much the better, as the rain removes the oil from the leaves and renders them more inflammable.

At the end of from sixty-five to eighty-six days the tobacco is ripe, the leaves begin to droop, and they are promptly gathered, being plucked one by one, threaded on strings, and tied into bundles which are sent to the drying-chambers.

A quicker method consists in cutting the plant down at the level of the soil and hanging it in the dryingchamber in that condition; but as the lower leaves are of greater value than the rest these should be carefully plucked by hand. In the great bamboo drying-rooms the tobacco is left hanging from laths and kept from the light for thirty or forty days; the leaves are then arranged in bundles of forty to fifty, according to their length, colour, and thickness, and are then taken to the fermentation sheds. In these sheds, which are nearly always of stone, roofed with galvanised iron, the tobacco undergoes the last stages of its preparation : fermentation, sorting, and compression into bales. Fermentation is induced by placing the tobacco in piles upon a plank of wood. As the fermentation is very lively at the outset, these piles contain only $5 \mathrm{lb}$. or ro $\mathrm{lb}$. of tobacco to begin with; but towards the end of the process they amount to $60 \mathrm{lb}$. or $80 \mathrm{lb}$.. A thermometer protected by a sheath of bamboo is often inserted in the fermenting heap, in order to indicate the exact temperature, so that fermentation may be checked at the right moment; for it is possible for the leaves to grow so hot in a single day as to burst into flames. When the temperature of the fermenting heap is the same as that of the air in the fermenting chamber the process of fermentation is over, and the piles are demolished, the leaves re-sorted, and made up into bales of $16_{5} \mathrm{lb}$. to $220 \mathrm{lb}$., which are sewn up in matting and exported, chiefly to Amsterdam and Rotterdam. 
All these processes, demanding the most precise and minute attention, require the supervision of Europeans, so long as the Javanese themselves remain insensible to the large profits which they themselves might draw from the improvement of their own methods. ${ }^{x}$

In $1895,9,807$ tons of tobacco were exported from Java to Europe. The increase in production has since then been constant ; in 1907 , a particularly good year, it amounted to 37,892 tons.

With the development of the native tobacco trade and the increasing production of tobacco in Sumatra, and also in certain parts of Borneo, the exports have reached the total figure of 69,489 tons, the value being approximately $£ 2,645,835$ for Java, and $£ 3,250,000$ for Sumatra.

\section{IV.}

Tea constitutes a smaller but very appreciable source of revenue for the East Indies, which are among the great tea-producing countries. The tea-plant does best at a height of $I, 500$ to $I, 800$ feet, but may be grown at all altitudes from 480 to 3,200 feet, provided the soil is clayey, rich in organic matter, and well drained. Until I 890 only Chinese tea was planted in Java; to-day it is being everywhere replaced by Assam tea, and other hybrid varieties which partake both of the Assam and the Chinese varieties. Assam tea, while much hardier than Chinese, is also more profusely leaved. The Preangers, Batavia, Kedu, and Pekalongan are the best tea-growing provinces in Java; the Preangers alone furnishing more than all the rest put together.

The tea-plant is reproduced by seed. The seed, having been gathered at maturity, when the capsule opens to allow the seed to escape, is sown in beds and transplanted, or in the open and in situ, at a depth of an inch and a quarter or two inches. If the seeds are fresh they should germinate in a ratio of two in three; otherwise

' See O. J. A. Collet, Le tabac, sa culture et son exploitation dans les régions tropicales. Le tabac à Sumatra (Brussels, 1903, large 8vo). 
only a quarter to a tenth will come up. Some planters take the precaution of allowing the seeds to germinate in a layer of mould, planting them only when they have begun to germinate.

As the soil must lie lightly about the shrubs, the plantation must be dug over two or three times a year, and weeded once a month. In the third or fourth year trenches are dug between the shrubs, measuring some Io feet long by 12 inches wide by 6 deep, in order to air the roots. The young shrubs must also be plentifully smoked. The crop may be gathered in the third or fourth year. The first yield is always scanty, but the succeeding crops are more and more plentiful, and welltended shrubs produce almost indefinitely. They are closely pruned once a year to prevent them from flowering; although at high altitudes a pruning every second or third year is sufficient. The same shrub will yield yellow tea, black tea, and a number of different qualities of tea; the two leaves at the tip of each twig furnish Orange Pekoe, the finest of all, whether green or blackthe colour depends upon the after-treatment; the lower leaves make their appearance as Souchong; the lowest of all are sold as Congo.r

Green tea is obtained by drying the newly-plucked leaves at once upon heated iron plates; so as to prevent the fermentation and oxidisation which turn the leaf black. To obtain black tea the leaves are first scattered and exposed to the air, when they shrivel and curl up ; they are then rolled and bruised several times in roller-machines, for ten or twelve minutes each time; they are then placed in flat bamboo baskets or trays, to ferment and oxidise by contact with the air, and finally go to the drying-machine. ${ }^{2}$

x Concerning tea, see H. Neuville, Technologie du thé. Composition chimique de la feuille. Récolte et manipulation. Procédés européens. Procédés asiatiques (Paris, 1905, large 8vo).

2 The usual form of drying-machine consists of a series of metal drawers with perforated bottoms, which slide into an iron frame or chest. Hot air is drawn or driven up or down through the whole.[TRANS.] 







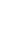




\section{AGRICUL'TURE : VARIOUS CROPS 233}

Tea-planting has been in a state of continual expansion in the Dutch Indies since 1865 , when the State renounced its monopoly. In 1907 the crop amounted to I I,494 tons.

V.

The trade in quinine is as vigorous and valuable as that in tea. This precious tree, according to Junghuhn, was introduced in 1854, from Callao, by the botanist, Justus Karl Hasskarl, after a long and perilous voyage. The forty-eight trees which were still in a healthy condition when Java was reached were immediately replanted in the garden of Tjibodas, at a height of nearly 5,000 feet above sea-level, by the famous botanist-gardener, Teysmann.

The experiment was so completely successful that the cultivation of the cinchona-tree was rapidly taken up throughout the Preangers, and then in the centre of Java. After a great many experiments the Buitenzorg laboratory discovered that the species Calysaya, imported from South America in 1865 , thanks to the tenacity of the merchant Ledger, was far richer in quinine than any other variety. Since then Cinchona ledgeriana has been planted everywhere, and a certain number of Officinalis and Succirubra imported from Ceylon; a limited number, because these two species are valued more especially for the bark, as sold and compounded by the pharmacist; and the demand for this bark being limited, the planters have only planted it in proportion to the commercial demand. It is becoming more and more usual to graft Ledgeriana with Succirubra, without which precaution it grows more slowly and offers less resistance to disease. The cinchona, indeed, is subject to many complaints; sometimes a fungus will rot the roots, and nothing remains but to burn the trees attacked and disinfect the soil wherein they grew; sometimes a blight or rust attacks the branches, which must be lopped and burned; sometimes a more dangerous pest, the Helopaltis Bradii, pierces the leaves and the young branches, sucks the sap 
and kills the shrub; and so far no one has found any better remedy than to burn the insect and its victim.

The cinchona is generally reproduced by seed, and is grown in a nursery and transplated as soon as the young tree is about 3 feet high. It requires much the same treatment as coffee. From the time the trees are four years old a small crop may be obtained by pruning the tree, which process may be repeated until maturity. From the sixth or eighth year the plantation yields a good harvest, which may be obtained in four ways: by uprooting the tree; by cutting it down to the level of the soil ; by removing longitudinal strips of bark, as is done in the case of the cork-tree, so that the bark can grow again; by removing the bark with a plane or shaving-iron down to the cambium only, only removing the second half when the first has regrown. The tree is never peeled with a steel knife, which would spoil and discolour the bark, but with a knife of horn or bamboo.

The bark is then dried in the sun, or by artificial heat in special appliances. It is then sorted and put up into bales; an operation which requires great care, as the qualities intended for the manufacture of quinine must not be mixed with those intended for pharmaceutical preparations-extracts and tinctures of cinchona and cinchona wine. In ten years the production of cinchona has almost trebled; in 1907 it amounted to 8,985 tons. ${ }^{\mathrm{I}}$

Cinchona is grown upon ninety-three leasehold plantations, seven Government estates, and five private freehold plantations. Javanese cinchona has lately profited by the failure of the Cingalese article. The bark is sent to Amsterdam, and thence distributed throughout Europe, or sometimes directly to England, which buys a great quantity.

× In virtue of a convention with the Government the Bandung factory is entrusted, from December 3I, I904, to transform into sulphate of quinine, destined to be sold in the Batavia market, a portion of the cinchona bark gathered in the official plantations of the Preangers. 
The manufacture of the sulphate of quinine, which has developed with great rapidity, has its centre at Bandung, where the Bandocngsche Kininefabriek is situated. The manufacturers are not only attempting, by acquiring the bark from all the Javanese plantations, to keep the greater part of the European trade in their own hands, but also to compete with the trade of the Far East: of China, Japan, the Philippines, the English and French Asiatic colonies and possessions, and even of Australia. $x$

As soon as a consignment of cinchona arrives the Kininefabriek extracts quinine from three samples of the bark. One sample is required to determine the richness of the bark in quinine, one is sent to the planter, and one put by for reference. The Company does not buy cinchona at its own risk; it simply undertakes to manipulate it for the planters and to find a market for the resulting products. At the end of the year the profits are divided proportionately between the planters, with the exception of a certain sum to cover the Company's expenses and yield it a net profit.

Equipped for a capacity of some 3 cwt. of sulphate of quinine daily, the Bandung Company has been enlarging its factory and laying down plant for producing other salts of quinine, such as chlorohydrate, bromohydrate, \&c. ${ }^{2}$

x The State grows cinchona on its own account in the Residency of the Preangers. The results of this industry-the Gouvernementskinaonderneming - were published quarterly in the Favasche Courant. Upon addressing their request to the Director of Agriculture, botanists, scientific institutions, and foreign Governments, through the medium of their diplomatic representatives, obtain free of cost small quantities of bark or cuttings of cinchona.

"Concerning quinine and its introduction to the Dutch Indies, see C. R. Markham, "Travels in Peru and India while superintending the collection of Cinchona plants and seeds in South America and their introduction into India" (London, I862, 8vo).-K. W. van Gorkom, Die China cultur auf Fava (Leipzig, 1879, 8vo); and the same writer's Kinologische Schetsen (Amsterdam, I892, 8vo).-E. Prud'homme, Le quinquina. Culture, préparation, commerce (Paris, 1902, large 8vo). 


\section{VI.}

Indigo is one of the products of which the State renounced its monopoly, partially in I854 and wholly in 1865 ; not without loss, for at that time the indigo industry was one of the most profitable and most widely developed in the Dutch Indies. Introduced perhaps by the Hindus, and certainly first prepared by them, as its name would seem to indicate (in Malay, Javanese, Sundanese, and Macassar nila = the Sanscrit nila, or. "deep blue"), the indigo trade was already flourishing when the Portuguese and the Dutch first arrived. The natives were using it largely in dyeing, or batiking, their cloths; even to-day they cultivate more than 50,000 acres.

The cultivation and preparation of indigo was one of the industries which Van den Bosch was most anxious to develop, and one from which the natives appear to have suffered most severely. To-day, in addition to the native industry, which is carried on more especially to supply local needs, European planters have devoted some 50,000 acres to the cultivation of indigo, this area being distributed throughout the provinces of Batavia, Pekalongan, Kediri, Surakarta, and Djokjakarta. The indigo of Djokjakarta, and particularly that of Surakarta, where the land is let on lease by the East Indian Government, is by far the most valued in Europe, and makes threequarters of the total yield.

The species of indigo cultivated in Java for the European market are the Guatemala ${ }^{\mathbf{r}}$ and the Natal ${ }^{2}$ varieties. The indigo plant, whose reddish, oblong leaves yield the colouring matter, grows best in the sawahs and on irrigable soil, in alternation with rice, or sometimes with sugar-cane. When the soil has been ploughed and

- Indigofera tinctoria L., I. pseudotinctoria, I. oligosperma D.C.: in Javanese, tom Presi, or Persian indigo.

${ }^{2}$ Indigofera leptostachya D.C.-Javanese tom Natal. Another kind of indigo produced in Java, whence the kind known in Malay as tarum kembang probably derives, is furnished by Indigofera anil L. Its Javanese name is tjantik. 


\section{AGRICUITURE: VARIOUS CROPS 237}

manured the seeds are sown in frames, and the young plants are transplanted as soon as they are of suitable size. In five or six months the plant is fully developed; its perfect maturity is announced by the flowering season. The bush is then earthed-up, and a first harvest gathered; three months after a second crop of leaves is ready for removal, and this second harvest is far superior to the first. It is sometimes followed by a third and fourth, if the bush be rich in leaves.

The leafy stalks, tied into bundles, are placed in tanks for the process of fermentation, which should last from four to six hours. A long experience is necessary before the watcher can divine when the fermentation has reached the correct stage.

The greenish-yellow water which is drawn off from the fermentation tanks flows into the threshing tanks, in which the indigo becomes precipitated. It is subjected to a process of clarification which lasts for two or three hours; it is then filtered, an operation requiring five or six hours; then the paste, or sludge, of indigo is mixed with a definite quantity of water, and is boiled with the greatest precautions against burning. A second filtration leaves the product in such a state that it may be pressed to expel the residue of water. It then only remains to cut it into tablets, which should be left twenty-five days to dry. They are then polished, to remove any suspicion of mould and to give them a beautiful brilliant purple colour.

The indigo market for Java is at Samarang; the European entrepôts are at Rotterdam and Amsterdam; but a considerable quantity of the indigo bought by France-which is, with Germany and Russia, one of the best customers for this product-goes directly to Havre and Marseilles.

The discovery of artificial indigo has, of course, been a blow to the industry, which, in Java at least, is relying more and more upon the Far Eastern market, and especially upon Japan. But after reaching the value of $£ 330,000$ or more in 1898 (the yield being 1,094 tons), 
its total production has fallen to 289 tons in 1906 and I44 tons in 1907 . The industry seems on the road to extinction; a matter to be regretted, since agricultural labour is more healthy and usually furnishes products of superior quality, if more expensive, than industrial labour.I

\section{VII.}

Among the smaller agricultural industries of Java, we must not omit to mention pepper and the valuable spices which long ago were an inexhaustible treasury for the Dutch. To-day Java produces some 3,863 piculs of prepared pepper (about 238 tons) and 625 piculs ( 38 tons) of mace. Cinnamon is no longer produced for exportation; cotton and kapok are not sufficient for local necessities, although the latter has been produced in unusual quantities during the last few years. Cocoa, on the other hand, has done extremely well; its cultivation has spread rapidly in Samarang, Pasuruan, Besuki, Pekalongan, and Surakarta; in 1907 the yield amounted to r,380 tons, having almost doubled in ten years. ${ }^{2}$ The cocoa-palm was imported from America.

The cultivation of the opium poppy is forbidden in the Dutch Indies, the State, as in French Indo-China, having reserved for itself the lucrative and immoral monopoly of this dangerous drug, in order to meet the necessities of the natives, and also to draw a large revenue from the noxious habit of opium-eating and smoking.

The sale of opium in the hands of the Chinese, to whom it is leased, has been productive of such abuses that the Dutch Government has inaugurated the system of régie, upon the model of that employed in French Indo-China; and this system, first installed in Madura,

× Concerning indigo, see Dr. G. von Georgievics, Der Indigo vom praktischen und theoretischern Standpunkt dargestellt (Leipzig-Vienna, I892, 8vo).

2 Concerning cocoa, see A. Fauchère's Culture pratique du cacaoyer et préparation du cacao (Paris, 1906, large 8vo). 


\section{AGRICULTURE: VARIOUS CROPS 239}

Surabaja, Pasuruan, Probolinggo, and Besuki, where it has given good results, has been gradually extended. In rgor the State built in Batavia a factory (Fabrick der opiumregie) large enough to furnish all Java with opium. 


\section{CHAPTER XII}

FORESTS AND MINES. INDUSTRY. COMMERCE.

I. The forests of djati and of "natural woods."-II. The mines of Java ; the mining system ; petroleum.-III. Salt.-IV. Industries: their character; the industrial future of Java.-V. Institutions of credit and thrift.-VI. Internal trade and the means of transport and communication: roads, railways, rivers; steamer services between the various islands of the Archipelago.-The merchant marine of the Archipelago.VII. Post and telegraphs.-VIII. Weights and measures. The monetary system.-IX. The export trade ; customs, transport.

\section{I.}

JAVA, and indeed the whole Archipelago, possesses a remarkable wealth of native vegetation. The bamboo, the areca-nut, the rattan-palm, the coco-palm, the banana, the breadfruit-tree, and a host of other palms, multiply with a fierce and vigorous growth. The native has had little ado in finding among them nearly all the necessities of his daily life. The forests properly socalled, which are wonderfully rich in species, have for a long time been neglected; whence a deforestation in some parts so unreasonable that the Dutch Government has finally moved in the matter. It discovered, in the latter half of the nineteenth century, that certain forests, containing most valuable products, deserved a better fate than unchecked destruction. In 1869 the first Afforestation Act was passed; since then it has been fittingly improved and enlarged; but so far the Government has not contemplated the extension of its prohibitions beyond Java and Madura. The State concerns itself very little, 
even in the latter, with the "forests of natural woods"literally wild woods (wildhoutbosschen) - and gives nearly all its attention to the preservation of the precious teak forests (djatibosschen), of which it reserves the monopoly. Certain of these forests have been leased to private undertakings, which are strictly supervised; others are administered by the Residents.

Teak, in the Dutch East Indies, is the wood principally used for ship-building and all kinds of permanent structures. The odour of its natural oil keeps off the terrible termite, and even the teredo has the greatest trouble in piercing it. There are many varieties of teak, of various colours and qualities : thorny teak, flowering teak, oily teak, limestone teak, and above all the gimbal (gembel) teak, which is brown and greasy to the touch, and is preferred before all others for ship-building.

Cultivated teak is valued far above the wild or natural timber. In 1907 the area of the teak-forests of Java and Madura was $I, 665,000$ acres; this area the Government is doing its utmost to increase, planting teak wherever there is a waste or fallow piece of land, along the wayside, \&c.

At regular intervals the Government proceeds, at the seats of the Residencies, to lease its teak forests in sections of 250 to 990 acres ; occasionally, but rarely, as much as 9,880 acres is leased. After a forest inspector has estimated the quantity of timber to be felled each year, the section is leased, for a term varying from two to ten years, for an annual royalty of 13 to 20 florins per cubic metre (about $\oint_{\mathrm{I}}$ to $\oint_{\mathrm{I}}$ I 2s. per cubic yard). The principal leaseholders are the Chinese, but two of the Dutch companies, the Favasche Boschexploitatie Maatschappij and the Nederlandsch Indische Houtaankap Maatschappij are large and important enterprises.

In 1907 the Dutch Government derived from its forests (the sale of "wild woods" being included) a net profit of nearly $£ 200,000$.

Ebony-in great demand in France and China-and sandal- or santal-wood, for which the best customer is 
Germany ; eagle wood and laka wood (Mynistica iners?), which is exported chiefly to Singapore, and iron-wood, are the most valuable of the woods found in the "wild woods," the supervision and extension of which will one day assure the Dutch Indies of a large yearly revenue. ${ }^{x}$

II.

The State monopolies include not only the forests, but to a certain extent the mines and the production of salt.

Legislation concerning the mineral wealth of the Indies is of quite recent date, although certain mines were exploited long before the advent of Europeans. It was only in 1895 that a mining law was promulgated in Holland; but this law, we must admit, was sufficiently autocratic. The State arrogates by law the possession of the entire subsoil of the Indies; the landowner who discovers a mine upon his property cannot become the owner, but only the concessionaire. He cannot prospect without permission, still less work the mine upon his own initiative.

A permit for research or prospecting is given for three years. This may be prolonged by a maximum period of two years; never more. Work must be commenced the first year, and the first applicant obtains the preference. The mining concession, which may be renewed indefinitely every seventy-five years, is only granted if the mineral sought for lies actually within the limits of the ground for which the permit is issued, and if its exploitation is technically practicable.

The State imposes a fixed tax of 50 cents (equal to Iod.) per hectare, or rather less than 2 d. per acre, and 4 per cent. on the gross yield of the mine. The prospector's permit is subject to an annual tax of 5 cents per hectare-a little less than a halfpenny per acre.

The products of prospecting may be disposed of without restriction up to a maximum which varies

' See Serre's L'exploitation de forêts de teck et autres bois à fava in L'Agriculture de pays chauds, 1906, pp. 422-430. 
according to the mineral in question. Above this the royalty of 4 per cent. upon the gross yield becomes payable.

Having the capital of Holland behind it, and being by no means anxious to establish powerful foreign companies within its empire, the Government of the Dutch East Indies grants prospectors' permits only to Dutchmen and to foreigners who have been domiciled for a certain period in Holland or the Dutch East Indies. The majority of the members of the board of every mining company must be Dutchmen or domiciled in the Indies. The concessionaire, if he does not reside in the Indies, must have a duly accredited representative, and the company must give proof of a sufficient financial capacity.

Java, from the miner's point of view, is infinitely poorer than Sumatra and Borneo, and the Riouw Archipelago ; it produces only petroleum, a little iodide of copper, and manganese. The yield of petroleumwhich is found in Samarang, Rembang, and Surabajaamounted to $27,697,340$ gallons in 1907 ; of iodide of copper some 28 tons were produced in Samarang; and of manganese, which is confined to Djokjakarta, 4.5 tons were produced. $\mathbf{x}$

Javanese petroleum is in the hands of a score of companies, the most important being the Industrial Petroleum Company of Dordrecht (Dortsche PetroleumIndustries-Maatschappij), which has a working capital of $12,000,000$ florins.

The capitalists of Holland are taking a great interest in the development of the petroleum industry in the Dutch Indies; they have invested very large sums in order to fight more efficaciously against the competition of America and Russia. It is indubitable that the petroleum fields of Java constitute an enormous source of wealth, and that they are gradually capturing the

: See J. G. Bousquet's Les richesses minérales des Indes orientales néerlandaises in the Mémoires et comple rendu des trav. de la Société des Ingén. civil. de France (Paris, 1907, 8vo; pp. 436 et seq.). 
markets of the Far East, of India, Indo-China, China, Japan, and the Philippines.

\section{III.}

The preparation of salt, obtained from the saline springs which abound all over Java-there are ${ }_{15} \mathrm{I}$ in the Regency of the Preangers alone-or from sea-water, is monopolised by the Government. Certain springs, such as those of Tji Ampel in the district of Krawang, yield a brine which is estimated to contain nearly 3 per cent. of salt. The natives, who are exclusively employed in the preparation of salt, often evaporate the saline water in great iron cauldrons, or kuwalis; sometimes, as in the district of Kradenan in Samarang, they first of all concentrate it in oblong tanks or wells, 7 or 8 feet wide, a trifle over 3 feet deep, and 30 feet long. These two methods of preparation may be undertaken by the natives upon payment of an annual royalty in proportion to the amount produced.

In Madura the Government undertakes on its own behalf the manufacture of salt by European methods from sea-water, which is allowed, at high tide, to flow into a system of little locks or sluices, to enter a series of salt-pans, and deposit its salt by evaporation.

In 1907 the State sold $1,390,73^{8}$ piculs of salt, produced in Java and Madura, for 9,622,033 florins, or $£ 801,836$.

\section{IV.}

The industries of the Dutch East Indies, with the exception of native specialities of purely local interestpottery, coppersmith's work, basket-making, the forging of kreeses, the designing of batik sarongs, handkerchiefs, \&c.-are still little more than a dependency of agriculture. The factories now built, or being built, in Java serve almost exclusively for the preparation of natural products : rice, coffee, sugar, tea, tobacco, quinine, indigo, \&c. A few saw-mills and printing-works, soap, 
ice, and mineral-water factories, can only be regarded as interesting experiments; their scope is as yet too limited to allow us to predict a brilliant future for Javanese industries.

The silk industry has hitherto yielded appreciable results only in the hands of the Chinese.

The climate of Java is warm enough for the mulberry, but too damp; the tree does not grow quickly. Silkworms, under the influence of the constant heat, spin all the year round and lose their stamina; while in Japan they cease to spin in the winter.

It has been hoped that by means of hybridisation a bombyx might be obtained which would resist the climate ; but hitherto all the silk obtained by European makers has cost more than it has sold for, and there are now only three silkworm-breeding establishments in Java : the most important, that of Pangkalan (in Batavia), which is combined with a winding-factory, is the only one which has yielded its owner profits. It is the property of a Chinaman, who exports his raw silk to Hongkong and even to Lyons. ${ }^{x}$

There are two factors, however, which seem to ensure the future of Javanese industry. One is the abundance of cheap labour: the daily wage of the field-labourer, excepting at exceptional times or for tending to exceptional crops, does not exceed 9 d. or Iod.; and although the Javanese is not muscular he is sober, skilful, docile, and capable of doing excellent work.

Secondly, although Java possessess no coal-mines, Borneo and Sumatra are rich in coal measures. These two factors are important elements of success.

$$
\text { V. }
$$

The capitalists of Holland turn naturally to the East Indies, and have powerfully contributed to the development of agricultural products in the colonies. They have

${ }^{*}$ See P. Serre's La Sériculture et lindustrie séricigène à Gava, in L'Agriculture des pays Chauds, 1906, pp. 347-349. 
it within their power to develop the production of manufactured articles.

For a long period they did not care to run the risks of investment in manufacturing enterprises, on account of the exacting State monopolies, which stood in the way of all private enterprise. In I828 the Bank of Java (Favasche Bank) began to place its reserves at the disposal of Dutch merchants in the Indies. In 1837 the Government began to introduce, or rather to allow, the free labour of the natives; and the Indo-Dutch Banking Company (Nederlandsch-Indische Escompto-Maatschappij) opened large credit accounts for the benefit of private agricultural enterprises. In 1862 these accounts had increased to such an extent that the money market in Java was badly strained; in 1863 the mother-country found it necessary to come to the rescue, and realised that it was to her interest to do so. The Indo-Dutch Bank of Commerce (Nederlandsch-Indische Handels Bank) of Amsterdam, the Bank of Rotterdam, and the Rotterdam International Society of Commerce and Credit (Internationale Crediet en Handelsvereeniging "Rotterdam") opened branches in Batavia, but were anticipated by the English "Chartered Bank of India, Australia, and China."

The Indo-Dutch Bank of Commerce was the only one to prosper, which in I88I founded in Amsterdam the Colonial Bank (Koloniale Bank).

In 1878 the "Amsterdam" Society of Commerce (Handelsvereeniging "Amsterdam") entered upon a commercial career, and also advanced money to finance agricultural undertakings.

In 1884 the crisis brought about by the tremendous fall in the price of sugar ruined nearly all these institutions. The Indo-Dutch Commercial Bank saved itself only by reconstruction under a new name, reappearing as the Indo-Dutch Agricultural Society (NederlandschIndische Landbouw Maatschappij). The crisis was soon over, and the banks developed as the island prospered, with whose fortunes their own were bound up. To-day the following institutions give a solid support to the enter- 
prises which are incessantly springing up throughout the Dutch Indies : the Bank of Java, the Dutch Society of Commerce, the Indo-Dutch Discount Society, the IndoDutch Agricultural Society, the Indo-Dutch Bank of Commerce, the International Society of Credit and Commerce, the "Amsterdam" Commercial Society, the Colonial Bank, the Principalities Agricultural Company (Cultuur-Maatschappij der Vorstenlanden), the Indo-Dutch Bank and Credit Society, the Indo-Dutch Mortgage Bank (Nederlandsch-Indische Hypotheekbank) of Batavia, and the Javanese Mortgage Bank (Favasche Hypotheekbank) of Amsterdam, which has its branch establishment in Surabaja. ${ }^{x}$

It is perhaps a pity that there are no similar institutions to come to the aid of the native industries and native agricultural enterprises, which are both as yet in a rudimentary stage. Lacking sufficient technical knowledge, without traditions, nor an education which might impel them to engage in commerce or manufactures, the Javanese masses are devoid of the funds necessary to equip any enterprise in a modern and remunerative manner.

For centuries the Javanese has been confined to his piece of land; forbidden all ambition; deprived of the fruit of his labour, which he has yielded, the more surely to ruin himself, to the Chinaman or Arab; and the native chiefs have been even more absolute in their cruel indifference than the Dutch Government itself.

To-day Holland wishes to uplift the native; to render him henceforth more capable of adding to and sharing in the prosperity of Java ; later on, no doubt, to help him to direct his own destinies. But the native has neither foresight nor an inclination to save; and he dislikes the anxieties of commerce, in which he feels that he is still

' See N. P. Van den Berg, Coup d' ail sur les institutions de commerce et de crédit aux Indes Néerlandaises, in Expos. univ. intern. de 1900 à Paris. Guide à travers la section des Indes Néerlandaises (The Hague, 1900, 8vo, p. 54 et seq.), and the article by the same author, Crediet instellingen in the Encycl. v. Ned. Indie. 
too much the novice. Agricultural enterprises might succeed in the hands of chiefs who are possessed of capital; but they are too often completely idle, and utterly inept in everything but the pursuit of trashy pleasures. The masses possess nothing; so that the great necessity on all sides is education, and under certain circumstances, credit; for European trade has expanded as it has solely by means of credit.

The year I897 saw the foundation in the Residency of Banjumas of a credit establishment for natives: the "Poerwokertosche Hulp-, Spaar-en Landbouwcrediet-bank." This bank has already been of very great service, and native trade in the region of Poerwokerto has greatly developed, which leads one to hope that the bank will soon open branches, or that rival establishments will be founded in all parts of Java.

The propaganda instituted among the Javanese with the object of inducing them to put by little hoards in the savings-bank, is also bearing fruit. Each year there is a slight increase in the number of accounts and the total of the sums saved. That this increase is not greater is due, not only to the Javanese lack of prudence, whether native or acquired, and the suspicious traditionalism of the Javanese, but to his actual poverty. To be able to save he must first have enough to eat; such is not always his condition, even upon the fertile soil of Java.

\section{VI.}

The transport of articles of commerce, both in Java and out of it, is facilitated by excellent means of communication, both by land and by sea.

Thanks to Daendels, who gave the first impulse to road-making, and built the best possible type of road for the country, the island is traversed from east to west by a magnificent double highway, which brought fresh life to the north of the island. Since the time of Daendels roads have been built almost everywhere, with more or less success, the work of supervision having for a long 
time been left to the native chiefs, while the work was performed by means of corvées. The introduction of free labour had an excellent result upon road-making, as upon everything else. It was obviously to the interest of the planters that the roads leading from their plantations or factories should be kept in good condition, since they depended upon them for the transport of their products; the result was that they expended pains upon them by which every one benefited.

The foundation of a department of bridges and highways in Java has been of great benefit to the country. The engineers have built solid bridges across the bandjirs, or torrential watercourses, replacing the frail bamboo girders which were constructed by the natives, and were periodically carried away, thus leaving portions of the island absolutely isolated, sometimes for months at a time.

But the roads, except in the more inaccessible places, where they are in the worst repair, and also the sole means of communication, do not now play the preponderating part in the commercial life of Java. Less and less frequently are they furrowed by the heavy glindings (native transport wagons). Both the white man and the brown have turned, with equal enthusiasm, from the road to the railway; a fact which proves that the brown man is perfectly accessible to the victories of progress. For a long time the State, actuated by a narrow, distrustful, and egotistical jealousy of its domination in Java, refused to allow the construction of railways.

In 1863, however, it granted permission to Messrs. Poolman, Fraser and $\mathrm{Kol}$ to construct and exploit a line of railroad running from Samarang, through Surakarta and Djokjakarta, to Ambarawa. In 1868 the same company received permission to build a line from Batavia to Buitenzorg. What with various unforeseen contingencies and impediments, some of which were not easily overcome, and delay in the actual work of construction, these two lines were not finally opened to the public until 1872 . 
Their success was complete, in respect both of the services rendered to the planters and natives and the profits realised by the builders.

Since then the State of Holland has constructed railways (Spoorwegen) both in Java and Madura. To-day the two islands contain some 1,320 miles of railroad, earning 6923,600 in net profits. The railway now traverses the great island from end to end; starting from Batavia, whence it throws toward the west two small branch lines to Anjer and Labun respectively, it there turns southward, serving Buitenzorg and Sukabumi; turns sharply to the north, reaches Padalarang, and sends out a second branch to Batavia, encircling the whole province of that name. The main line then turns southward once more to Bandung, crosses the Preangers, the Residency of Banjumas, the two Principalities of Djokjakarta and Surakarta (Solo), meets the old Samarang railway, runs westward to Surabaja, and then encircles the western portion of the island to end at Banjuwangi and Situbondo. This magnificent system is completed by a steam tramway system (Stoomtramwegen) which runs along the north coast of Java, covering a length or $1,55^{\circ}$ miles and bringing in a revenue of £800,000.

Transport in the centre of Java profits little by the narrow watercourses by which the surface of the land is furrowed, owing to the torrential nature of these streams, and the wealth of their alluvial deposits. Few of them can be ascended by anything larger that the native prahou, and even so the ascent is extremely slow. Only the Tjiliwong of Batavia, the Tjitarum, the Tjimanuk, the Tjitanduwi, the Seraju, and the Solo and Brantas Rivers are navigable for larger vessels, and only for a small proportion of their courses. All such work as the cutting of canals and the cutting or dredging of channels has been so quickly rendered useless by the constant deposit of silt or mud that further attempts to improve these rivers were long ago discouraged.

To turn to the sea, however, we find that there is a 
very active movement between the various ports of Java, and between Java and the rest of the Archipelago. The Royal Packet-Boat Company (Koninklijke Packetvaart Maatschappij), which is subsidised by the State, obtains much of this traffic. In 1907 this company owned $5^{1}$ packet-boats, carrying 407,965 passengers. An English company, with its headquarters at Singapore, serves the ports of Java, of the eastern coast of Sumatra, and the western coast of Borneo, and competes, to a certain extent, with the former company. The Royal PacketBoat Company carries, besides its passengers, the salt produced by the State, and coal from Ombilin for Government use.

In 1907 the movements of the mercantile marine in the Dutch East Indies, exclusive of the Royal PacketBoat Company, were represented by the following figures : 190 steamers, 145 European sailing-vessels, and 2,327 native sailing-vessels; in all 2,795 vessels, with a capacity of some 567,000 cubic yards, or some 430,000 tons displacement. For Java and Madura the figures were 1,640 vessels and 335,000 cubic yards capacity.

\section{VII.}

Transactions with the interior of Java, the Outer Possessions, and the rest of the world are facilitated by an excellent system of posts, telegraphs, and telephones.

On the 3 ist of December, 1907 , the number of postoffices in the Dutch Indies was 291 ; there were 176 telegraph offices in the cities and 367 in the railwaystations, and there were $5^{8}$ public telephone offices. There were 5,600 miles of telegraph lines, 8,740 miles of wires, and 3,250 miles of submarine cables.

\section{VIII.}

The adoption by Holland of the metric system of weights and measures, and her introduction of that 
system into the Dutch East Indies, has greatly facilitated the conduct of trade.

The Dutch monetary system, on the other hand, which is quite peculiar to Holland, is troublesome to the foreigner. The pound sterling is accepted everywhere, but the importation of Asiatic coinage into the Dutch Indies is strictly prohibited; so that the first care of the merchant or the tourist, upon landing at Tandjong Priok, is to obtain a supply of Dutch currency from a money-changer or a bank-that is, if he has not already done so before beginning the voyage. The monetary standard is the piece of Io florins, weighing 6.72 grammes, the purity being 9 , and the value that of 6.048 grammes of pure gold. The standard of silver money is the florin or gulden, weighing ro grammes, containing 945 of pure silver, or 9.45 grammes. Its value varies from $20^{\circ} \mathrm{I} 6$ pence to $19^{\circ} 968$ pence; approximately twelve are equivalent to the pound sterling English. The silver coins are: the gulden or florin, divided into roo cents; the rijksdaalder, or rix-dollar, worth $2 \frac{1}{2}$ florins, or the value of an American dollar; the half florin, the quarter florin (kwartje), and the tenth of a florin (dubbeltje).

The principal golden coin is the piece of ro florins, worth I6s. $8 \mathrm{~d}$.

The smaller coins are: the 5 -cent piece, in nickel (worth one penny), the $2 \frac{1}{2}$-cent piece in bronze (worth a halfpenny), and the I-cent and $\frac{1}{2}$-cent pieces, also in bronze.

IX.

The transportation of the products of the Indies to Europe and vice versâ is effected, for the majority of private exporters and importers, by means of the Rotterdamsche Lloyd line of steamers, and the Dutch Navigation Company (Stoomvaartmaatschappij Nederland). These lines also carry for the Government by annual contract.

The tariffs and customs duties have been profoundly 
modified since the fall of the system of compulsory crops, and since the declaration of Singapore as a free port.

In 1872 the narrow protectionist system which practically forbade foreigners admittance to the Indies, to the great detriment of prosperity of the islands, was abolished, and the flags of all nations were admitted on equal terms to the open ports. The enormous development of Singapore has since then led Holland to adopt a policy progressing towards free trade; abolishing or diminishing the heavy anchorage and pilot dues, and creating a series of free ports, in which exports and imports alike are subject to the provisions of commercial treaties between Holland and the interested Powers. ${ }^{\mathrm{I}}$

The total value of the imports received by the Dutch Indies in 1907 , including those destined for the Government as well as for private merchants, and inclusive also of gold and merchandise, was $£ 20,605,892$; Java and Madura alone absorbing imports to the value of E $12,726,722$. The value of the exports amounted to $£_{30}, 379,095$, of which amount Java and Madura accounted for $\oint_{17}, 636,249$.

The chief imports are rice, such edibles as butter, cheese, flour, pork, \&c., metals, machinery, woven stuffs, and manufactured articles generally. The principal

"Article 130 of the Regeeringsreglement (Fundamental Law of the Dutch Indies): "Every vessel belonging to a nation friendly to the kingdom of Holland is admitted to the ports of the Dutch Indies open to general trade, provided that it observes the general and local regulations. To the other ports only native vessels, and those which are authorised to take part in the coasting trade under the Dutch flag are admitted."

The ports open to foreign trade are called vrijhavens (free ports), and in such ports the Dutch Government imposes no restrictions or duties upon the entry and exit of ships or merchandise. The only official free port is Riouw, but in practice the ports of Bengkalis and Sabang (both in Sumatra) are treated as free ports. The Inlandsche havens (native ports) are the ports of the native princes and peoples whose islands are not directly governed by Holland, although they levy the customs duties. The entry to these ports is free to all vessels, 
products exported are coffee, sugar, tobacco, tea, quinine, cinchona, indigo, copra, and various oils and pelts.

The French, despite their interests in the Far East, and the neighbourhood of Indo-China, play a very small part in the carrying trade of the Dutch Indies.

On the other hand, the figures relating to Great Britain (in 1907) amounted to 563 vessels and 3,554 tons; Germany comes next with 318 vessels and $\mathrm{r}, 23 \mathrm{I}$ tons; Holland with 169 vessels and r,244 tons; but France comes after Norway, with 26 vessels only and 84 tons of merchandise; the lowest figures. In the same year the exports from France to the Dutch Indies fell from $f_{1} \mathrm{i6}, 660$ to $f_{108,500}$, and the exports from Saigon from

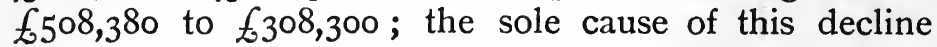
being the commercial apathy of the French. These sums are indeed miserable beside the $£ 2,833,330$ worth of English exports and the $£ 4,083,330$ worth from Singapore.

\section{$\mathrm{X}$.}

Passenger traffic from Europe to the Indies is effected, with all the comfort and ease imaginable, by large steamship companies owned by the principal European countries. The departures of the steamers are so arranged among the companies that approximately speaking a steamer passes any given point once in every three days. The most important lines are the Rotterdam Lloyd and the Nederland of Amsterdam (Stoomvaartmaatshoppij Nederland). Every other Saturday a boat owned by one of these lines leaves Europe with the mails. The Rotterdam Lloyd steamers touch at Southampton, Lisbon, Tangier, Gibraltar, Marseilles, Egypt, Ceylon, and vice versâ, and connect with vessels running to the various ports of the Archipelago. The price of the single passage, not including wine or beer, from Rotterdam to Padang, Batavia, Samarang, or Surabaja, is $£_{7} \mathrm{I}$ Ios. first class and $£_{4} \mathrm{I}$ I5s. second class. From Marseilles the fares are $£_{6} 7$ 2s. and 
$63^{8} 7 \mathrm{~s}$. No charge is made for children under three; and children under twelve pay half the full fare.

Every adult first- or second-class passenger has the right to take with him, free of payment, a cubic metre of luggage-about 34 cubic feet-and a deck chair. Extra luggage must be paid for at the rate of $\mathscr{E}_{\mathrm{I}}$ Ios. per cubic metre. The cabin trunk or portmanteaus to be kept in the cabin must not exceed $11 \frac{3}{4}$ inches in depth; and no nailed cases are allowed in the cabins. Ordinary luggage, with legible labels bearing the name of the owner and his destination, is placed in the hold, where it is accessible on certain days, excepting Sunday.

The Nederland carries passengers at the same charges and under the same conditions ; but it sails from Amsterdam, stops at Southampton, Lisbon, Tangier, Algiers, Genoa, Port Said, Suez, Perim, Aden, Colombo, Sabang, Deli-Penang, Asahan, Singapore, Batavia, Samarang, and Surabaja.

The North German Lloyd line sails once a fortnight from Bremen and Hamburg alternately. It touches at Rotterdam, Antwerp, Southampton, Gibraltar, Algiers, Genoa, Naples, Port Said, Suez, Aden, Colombo, Penang, and Singapore. At Singapore passengers tranship on board the steamers of the Koninklijke Paketvaartmaatschappij for Batavia, Samarang, and Surabaja. The price of the single passage from Bremen, Hamburg, Rotterdam, Antwerp, or Southampton, exclusive of wine or beer, is $£ 66$ first class and $£ 44$ second; from Gibraltar, Algiers, Genoa, or Naples the first-class fare is $f 6$ I I2s. and the second-class fare $\oint_{4} \mathrm{I} \mathrm{I} 6 \mathrm{~s}$. Each passenger may take $44 \mathrm{I} \mathrm{lb}$. of luggage free, the excess dues being about ros. per cwt.

The Messageries Maritimes run a fortnightly service from Marseilles, corresponding with the mails for Batavia. Passengers for Samarang and Surabaja are furnished by the agents of the company at Batavia with railway tickets for either of these cities.

The ports touched at are Port Said, Djibonti, Aden, Colombo, and Singapore (where the Batavia steamer is joined). The passage-money to Batavia, Samarang, or 
Surabaja, wine included, is $£_{67}$ first class, $£_{46} 6$ s. second class, and $f_{2} 44$ s. third class.

First- and second-class passengers are allowed $330 \mathrm{lb}$. ( 5 o kilos) of luggage free of charge ; passengers paying for the exclusive use of a first-class cabin may take $55^{\mathrm{I}} \mathrm{lb}$. (250 kilos) of luggage free. $I$ The excess charge is $f \mathrm{I}$ per $220 \mathrm{lb}$. (per Ioo kilos). Cabin trunks must not be more than $15 \frac{3}{4}$ inches deep or wide, nor $3 I_{\frac{1}{2}}$ inches long.

The abundant comfort and the comparatively low terms afforded by the Messageries Maritimes brings that company passengers of all nationalities.

Not only are merchants, financiers, and engineers flocking to Java; but for the last fifteen years there has been quite an influx of tourists of all nationalities, who have come to admire the "pearl of the Archipelago," which is also the fowl that lays the golden eggs; and more especially to continue, from Benares to Angkor Wat, and from Angkor to Batavia, the pilgrimage of admiration that even ungrateful humanity is forced to admit the due of the Hindu genius.

I The traveller should take with him as little as possible in the way of unnecessary clothes and boxes; he can easily obtain all he needs in Batavia, or the other large towns of Java, and at very reasonable prices ; especially in the case of tropical suits of white cloth or linen, which are cheaper and better than those to be obtained at home. Besides the necessary linen, pyjamas, cholera-belts, \&c., the traveller should buy for the journey a couple of blue reefer suits, a light lounge suit for the afternoons, and a dinner-jacket. Two suits of khaki will be useful. To these he should add a sun-helmet, a travelling cap, a soft felt or tweed hat, an overcoat, two pairs of boots or shoes, slippers, and stylograph, a photographic outfit, an umbrella and a parasol, a dressing-case, a cabin trunk, a collapsible pigskin bag, a strong linen or jute hold-all or kit-bag, a trunk for the hold, and a cane deck-chair (which he can buy at Marseilles). He will then possess the indispensable minimum. A woman will require, in addition to certain of the above articles, a few summer frocks, plenty of peignoirs, tea-gowns, and hats, all very light, and a good warm cloak for the evening. Some women prefer a sun-helmet with gauze veil rather than a hat. The above are merely general indications; the traveller can add to this minimum according to his purse and his individual tastes. 


\section{CHAPTER XIII}

THE OUTER POSSESSIONS (BUITENBEZITTINGEN). SUMATRA AND THE ARCHIPELAGO OF RIOUW LINGGA.

I. The various divisions of the "Outer Possessions," and the importance of Sumatra.-II. The dimensions, physical aspect, and coast-line of Sumatra.-III. The rivers and the sea-coast of Sumatra.-IV. The climate, flora, and fauna.-V. The native races; their origin, beliefs, and manners.-VI. The principal languages : the most useful language for the visitor to or inhabitant of Sumatra.

I.

ThE "Outer Possessions" of the Dutch East Indies comprise : (I) all the larger of the Sunda Islands, excepting Java and Madura-that is, Sumatra, Borneo, Celebes, and their immediate neighbours; (2) all the lesser of the Sunda Islands-Bali, Lombok, Sumbawa, Flores, Sumba, Alor, Timor, Rotti, Kei, Aru, \&c. ; (3) the Moluccas and the Dutch portion of New Guinea. Very much larger than Java and Madura collectively, often individually larger, and often as rich in natural products, they are inferior in the number of their inhabitants and in their civilisation.

From the administrative point of view the Buitenbezittingen have been divided into seventeen Residencies or Governments, established without much regard to ethnological facts, but rather according to their economic value, their political situation with regard to the central Dutch power. Sumatra contains three of these Residencies: nine if we count the Riouw Lingga Archipelago, 
the Banka islands, and Billiton or Blitung. Dutch Borneo, vast as it is, contains but two; Celebes and its dependencies two ; the Moluccas two ; Timor, the Flores, Sumba and Rotti one; Bali and Lombok one.

Sumatra is by far the most important of these Outer Possessions. Scarcely smaller than Borneo, some four times the size of Java, from which it is separated by the Straits of Sunda, it has an area of 180,380 square miles if we include its dependencies, or 167,480 square miles if taken alone; in short, its area, comparable to that of Spain, is thirteen times that of the Netherlands. Its population, on the other hand, is only $3,189,027$; an absurd figure when compared to the dense population of Java, or with the wide expanse of Sumatra itself, which might easily contain and support some seventy-five million human beings.

We have here the reason why Sumatra, whose soil and subsoil hold their own easily with those of Java in the matter of mineral and agricultural wealth, is only now commencing to attract the attention of the Dutch. Java is a country of magnificent realisation: Sumatra has only a great future. More advantageously placed than Java, on the threshold of the ocean highway from the West to the Far East, a close neighbour of the Malay Peninsula and of India, it seems to guard the entry to the China Sea, to Indo-China, China, and Japan.

This advantageous position, and a more complete knowledge of its natural resources, are to-day leading the Dutch Government to develop Sumatra with tenacious energy, in spite of the courage, independence, or fanaticism of populations which render the national organisation of the country a far more difficult task than the organisation of thirty millions of Javanese has been.

\section{II.}

Just as Java has often been compared, in respect of its shape and orientation, to Cuba, so Sumatra has been compared with the great French colony of Madagascar. 


\section{SUMATRA AND RIOUW LINGGA 259}

The extent and configuration of the two islands, each of which presents one almost rectilinear coast bordering on profound oceanic depths, while the other coast, much indented, slopes gently to a shallower sea; each of which is traversed by a backbone of mountain ranges, running in parallel chains from one extremity of the island to the other; the relative insalubrity of the coastal regions as contrasted with the hot but very healthy climate of the plateaux and valleys of the interior; all these facts contribute to a very real resemblance.

It would be more fitting, however, to compare Sumatra to Java, especially in respect of its geological, orographical, and hydrographical constitution; Java in many ways being but an attenuated continuation of Sumatra.

Sumatra, like Java and Borneo, is largely formed of strata of the tertiary period, although it also contains two schistous formations, one of which is anterior to the carboniferous period. The tertiary series is more complete than in Java; the numerous volcanoes, so characteristic of the whole Archipelago, are due to the quaternary period.

In Sumatra, which is still only partially explored, there have already been discovered ninety volcanoes, of which twelve are now active; they are, counting from north to south : Sinabung, Sibajak, Pusuk Bukit, Sorik Berapi, Pasaman, Singgalang, Merapi, Talang, Korintji, Kaba, Dempo, and Krakatau. These volcanoes are scattered amidst the series of mountainous groups which, under the name of the Barisan Mountains (Bukit Barisan) run the whole length of the island; closely approaching the western coast, and attaining their widest development in the southern portion of Sumatra. Whether naked or covered with verdure, majestically graceful or breached and shattered by their own eruptions, grouped in twos and threes, enclosing narrow valleys, or isolated and overlooking some fertile plain which they enrich and devastate alternately, surrounded by threatening vapours, or bearing in their craters a great circular lake of water, these volcanoes are the creative, the regulating, and often the 
perturbing factors of the orographic and hydrographic history of Sumatra. Their average height runs from 9,000 to nearly r 2,000 feet.

The first volcanic height of the Bukit Barisan encountered by the traveller whose direction is westward from the north-eastern corner of the island, is Sinabung; then the range splits up into parallel chains, which surround the vast lacrustine lake called the Sea or Lake of Toba, whose area is about 785 square miles, and its depth from I,300 to I,470 feet. A number of Batak villages are established upon its banks; they live by fishing and hunting rather than by agriculture or industry.

Then we come to Mount Malintang; then to Mount Pasaman or Ophir ; $^{\mathrm{I}}$ isolated and majestic, but uncertain and irascible in temper. Then, to the south of the beautiful Masang River, we reach Manindju, whose amputated summit bears the lake of the same name, whose slightly sulphurous waters flow into the Indian Ocean. Then follows Singalang; then Merapi, on whose summit, so the Islamites pretend, the ark of Noah rested after the Deluge. This region, cut up into innumerable valleys which run between the spurs of the mountains, contains another lake of considerable size, though its area is only one-eleventh of that of the Lake of Toba: the Sea of Singkarah. Further south still the chain continues past Talang and Korintji, or Indrapura (the dwelling of Indra, or of the gods, in the eyes of the natives), always in eruption, its base surrounded by a system of lakes, all smaller than the Seas of Toba and Singkarah. As we approach the southern extremity of the island the volcanoes, although less majestic, redouble their activity; here is Kaba, pointed like a sugar-loaf; Dempo, hailed by the Malays as the cradle of their race;

- So named because the old Portuguese navigators thought they had rediscovered the Ophir whence King Solomon drew the gold employed in building the Temple. Ophir has also been located in the east of Malacca, whence the name of Mount Ophir, sometimes given to Gunung Ledang, which contains considerable quantities of gold. Its actual location is in the Zambesi district. 


\section{SUMATRA AND RIOUW LINGGA 261}

Radja Besar, and Krakatau or Rakata. The rumbling voice of Dempo keeps the inhabitants of all the neighbouring valleys for ever on the alert, with bated breath ; and for three years, from 1875 to 1878 , Kaba sent forth rivers of lava. But Krakatau, upon its little inhabited island, after three months of low rumblings, and explosions of smoke and flame, which provided the many tourists who, in May, I883, came thither from Batavia, with a striking and somewhat alarming spectacle, was the centre of an eruption famous in the history of volcanoes. This eruption reached its apogee on the $27^{\text {th }}$ of August. For more than a month it vomited torrents of rocks and ashes, the latter reaching a height of seventeen miles and covering a stretch of nearly a thousand miles; obscuring the sun, and falling in a cloud of cinders upon the Keeling Islands (Cocos Islands), in the Indian Ocean. It seemed as though the amazing convulsions of this unfortunate island would shatter the very foundations of the globe. At Batavia, from the 26th to the 29th of August, the horizon remained obscured, and all Java was shaken by an extraordinary tidal wave, by subterranean shocks, and the sound as of a distant cannonade. Anjer and Tjaringin on the Javanese side of the Straits of Sunda, Benawang and Telok Betong on the Sumatra side, were utterly erased by a gigantic wave, $\mathbf{r} 20$ feet in height; not a trace was left of house, or crop, or human being. More than forty thousand persons were swept away and drowned; only the keeper of the lighthouse, which was I 30 feet in height, was saved ; the wave merely extinguishing his light. But over an area of fourteen square miles, all living creatures were burned to death ; and the two hundred inhabitants of the island of Sibesi disappeared beneath the waves.

The shores of the Straits of Sunda were completely altered in their configuration; the entire southern portion of the island of Krakatau had disappeared, to be replaced by a gulf nearly $\mathrm{r}, 000$ feet deep; but the mass of stones and cinders which were blown away had actually formed new islets and new patches of land, and had doubled the size of the Deserted Isle (Verlaten). 
The explosion of Krakatau was heard in the Philippines, and in Japan, and was followed by a rain of cinders; over all the southern portion of Indo-China as far as Lao, it sounded like the dull and incessant discharge of countless artillery ; it was heard, though less loudly, as far as Europe; in America, along the Pacific coast, it caused submarine tremblings and movements of the sea that for a moment seemed to threaten to ravage the coast ; and its tidal wave reached Madagascar, where masses of cinders and huge fragments of pumice were carried by the ocean currents.

To-day the terrible volcano, as well as the island, is reclad in a magnificent mantle of foliage, and has resumed its benignant aspect. ${ }^{x}$

III.

The rivers of Sumatra, together with the volcanoes, are the creative elements of the island. The great eastern plain is formed almost wholly of their alluvial deposits, and is slowly but surely being augmented by their continuous action. Richer in alluvial matter than the rivers of Java, on account of the enormous rainfall of Sumatra, these rivers have otherwise the same characteristics as those of the smaller island. On the steep western flank of the island, shut in between the coast and the mountain chains which border it, they are short, torrential, and rarely navigable. One of the most important is the Singkel, formed by the confluence of the Simpang Kanan (the right-hand Simpang) and the Simpang Kiri (the lefthand Simpang).

The rivers of the eastern watershed flow across the great alluvial plain, leisurely draining the mountains of their waters; their course is often majestic, but impeded by

× See C. Dietrich, edited by Prince Roland Bonaparte : Les premières nouvelles concernant l'éruption du Krakatau en 1883 dans les insulindes (Paris, 1883, large 8vo); R. O. M. Verbeek, Krakatau (Batavia, r886, large 8vo). 


\section{SUMATRA AND RIOUW LINGGA 263}

silt; and they finally reach the sea through numerous muddy channels.

Of these rivers the chief is the Asahan, which drains the enormous Lake of Toba; this, for a portion of its length, is navigable by steamers. Next is the Indrapura, which waters the lowlands of Padang, and finishes its individual course by dividing into several branches, of which three are the Sungi (river) Sindang, the Sungi Lunang, and the Sungi Tapan. Other rivers are the Rokan, which flows into the narrow Malacca Straits, after a journey of more than 120 miles, through a muddy estuary; the Siak, formed by the confluence of the Tapung Kanan (the right-hand Tapan) with the Tapung Kiri (the left-hand Tapan), which flows into the Brouwer Strait ; the Kampar, the Indragiri, which issues from the highlands of Padang, traverses the Sea or Lake of Singkarah, under the name of the Ombilin, waters the coal country, and finally debouches opposite the Lingga Archipelago, in the great Gulf of Amphitrite; the Djambi, springing from Indrapura, and swelled by the Batang I Hari and the Tambesi, is the most beautiful and the largest of all. Opposite Djambi it has a width of 1,300 feet, and at low water a depth of about 16 feet; but the least increase of tide or current doubles its depth. Steamers of considerable tonnage can lie 600 or 700 yards inland ; and native vessels (prahous or praus) some 900 yards.

The batang (or river) of Palembang, the Musi, is the only river to bear comparison with the Djambi. Below Palembang it splits up into a number of channels, which spread out amidst a vast, unhealthy swamp, covering an area of some 4,600 miles. These subsidiary channels slowly deposit their suspended wealth of mud among the mangroves, thus gradually creating new land. Native tradition states that Palembang, to-day 55 miles inland, was once a seaport; but through the centuries the alluvial ooze of the river has pushed the shore far out into

"Batang means "river" in Sumatra; the Malay kali and the Sundanese $t j i$ have the same meaning. 
sea. The principal branch of the Musi, the Susang, which flows into the Banka narrows, is accessible during the rains to vessels of considerable tonnage, and to vessels of moderate draught the whole year round.

The changeable nature of the coast hereabouts makes landing always an uncertain, and often an unhealthy business. The indentations of the shore are impermanent, and the muddy barriers of the Sumatra coast makes it no easy matter to establish practicable ports or landings. We can foresee that in the west, and more rapidly in the east, the immense mother-island will slowly gather to her shores the chaplet of rocks and shoals and islands which guard them from north to south. These islands, which are parallel to the western coast, to which they serve as a kind of outer barrier, have a total area of 5,760 square miles, and a population estimated at nearly 300,000. Starting from the north these islands are Simalur, Banjak, Nias, Batu, the Mentawei Archipelago, and Engano.

On the eastern coast the islands are even more numerous, and present more variety of size and grouping. Some are low and of alluvial origin ; the islands of Rupat, Padang, and Bengkalis, are already connected with the mainland by muddy causeways; others are of granitic formation, more of a volcanic character, and set further out at sea, such as the archipelagos of Riouw and of Lingga. Yet of these even Banka and Billiton show signs of future absorption by alluvial deposits.

\section{IV.}

The climate of Sumatra, like that of Java, belongs to the zone of alternate monsoons : the south-east monsoon, dry and hot, which lasts from May to September, and the north-west monsoon, which lasts from November to March, and which brings the heavy rains. The prevailing temperature is as high in the sister island, and always very equable, but the atmosphere is extremely humid. 


\section{SUMATRA AND RIOUW LINGGA 265}

The storms are most violent and most regular at Padang; they break especially in March and April, and always in the afternoon, between 2 and 6 p.m. They are also frequent at Palembang, especially from October to December.

The flora of Sumatra resembles that of India in the north of the island, and that of Java in the south; but it remains, in its wealth and variety, quite distinct from either. The vegetable growths are larger and more undisciplined than those of Java. There are flowers of the dimensions of the huge Rafflesia, ${ }^{\mathrm{x}}$ and also immense jungles of alangalang (Imperata arundinacea Cyr.) and of glaga (Saccharum spontaneum L.); herbaceous plants some 3 or 4 feet high, which stifle the trees, kill seeds and growing crops, and serve only as the haunt of wild beasts. These jungles descend as low as 800 feet above sea-level, while in Java they grow no lower than 3,000 feet. Here, from the economic point of view, is a serious obstacle to the development of Java. On the other hand, in addition to the usual series of palms, Sumatra possesses a greater variety of forest timber than other islands of the Archipelago, and produces gums and resins of great commercial value. Camphor, rubber, pepper, cinnamon, areca-nut, benzoin, and lacquer are found in abundance.

The wild beasts of Sumatra are plainly differentiated from those of Java. In the centre especially, and on the north-western coast, the elephant is native; and the rhinoceros, tiger, panther, tapir, and a few orang-outang are found.

The population of Sumatra, although so inferior in numbers, has nothing of the ethnographical simplicity,

- The largest flower known, discovered by the naturalist, Joseph Arnold, in 1818 , and named after Sir Stamford Raffles, LieutenantGovernor of Java during the English occupation. He was the author of the remarkable History of $\mathcal{F a v a}$ (London, $18 \mathrm{I} 7,2$ vols., 4 to). The blossom of Rafflesia Patma Bl. measures 20 to 24 inches in diameter; that of $R$. Arnoldi R. attains to a diameter of 36 to 40 inches Native names: krubut, ambun-ambun : tjendawan matahari. 
verging upon unity, which we find in that of Java. It is obvious from the first that there are very perceptible points of difference between the peoples of the coast and the peoples of the interior; which is easily explained, as the seaboard populations have for centuries come into contact with all kinds of foreigners, while those of the interior are only beginning to be known. The seaboard populations on the east coast of Sumatra, in the Lampong districts of Palembang and Djambi, were at an early date modified in respect of their physical type and their customs by the establishment of Hindu-Javanese colonies. The Achinese and Malays are distributed in considerable numbers in the north and north-west, where they originally settled for purposes of trade, and almost everywhere on these coasts Chinese, Klings, or Klingalese, Bengalis, and Arabs, have at some time settled, whence have resulted peoples of mixed race, far more open to the general life of the East than the tribes of the interior. These latter, who have not come into contact with foreigners, who are ignorant of the arts of learning and commerce, or of European civilisation, or indeed of any high civilisation, have in the past been slightly influenced by the Hindus, and in certain districts have not altogether escaped the influence of Islam. They have necessarily remained at a lower intellectual level than the coast populations; their condition, social, economic, and moral, is still extremely rudimentary. Yet on the coasts and in the interior the population of Sumatra seems to have a common MalayoPolynesian origin ; but diversities of climate and habitat, together with different economic and historical conditions, have evolved from this common parentage races very different in aspect and in language, despite their real and close relationship. The more important of these races are the Lampongs, the Redjongs, the Lebongs, the Gayos, the Malays, the Bataks, and the Achinese; the two most characteristic being perhaps (for different reasons) the Malays and the Bataks.

The Lampongs inhabit the districts of the same name 
at the southern extremity of Sumatra, on the Straits of Sunda, facing the country of the Sundanese, with whom they are in constant touch. Their alphabet proves that they were formerly under the influence of the Hindus, and attained a fairly high degree of civilisation. They live, poorly enough, by agriculture, and in the towns, to a certain extent by exchange. Their language seems to be related in many ways to the Sundanese, to Batak, and to Malay. The Lampongs are almost converted to Islam, but they preserve their adat, which is often in contradiction to the prescriptions of that religion. The Musulman faith is treated with greater respect in the coast towns, where marriages are celebrated in the Arab fashion, than in the interior. Marriage is an institution which in Sumatra affects the most varied forms, and therefore affords a good example of the struggle of the atavistic concept against the fashions imported by the foreigner. It is always exogamic; but while the common people regard it as a patriarchal institution, with wifepurchase (often ruinous), the woman becoming the absolute property of her husband, the wealthy and the notables preserve the matriarchal institution, as at Menangkabau, where possession of land and of children is the attribute of the mother.

Marriage is greatly honoured among the Lampongs, seduction and its results being considered as a disgrace to the whole village. It is general among the Lampongs for both sexes to file the teeth.

The Lebongs live upon the upper reaches of the Ketuan, in a province bearing their name, and blessed with a very healthy climate. The special dialect of the Lebongs is strongly mixed with Malay, which language they speak in addition to their own.

Their houses, raised on piles, which are carved and decorated in white and red, have walls of bark, and flat roofs of split bamboo. Islamism has begun to make its way among them, without greatly modifying their old animistic superstitions. They are a gentle and hospitable people. 
The Redjangs, of a much fiercer temper, live in Redjang, on the upper course of the Musi; in them Marsden mistakenly saw the type of the primitive Malay. Their writing - of Indian origin - has often been regarded as the actually unknown script which must have been employed by the Malays before Islam brought them the Arabic characters. Formerly animists, living in a country wherein Hindoo ruins are still discovered, and now converted to Islam, the Redjangs practise an Islamism full of relics of the past. For example, at regular intervals they bear offerings of rice and fruits to the crater of Kaba, which they venerate. They cultivate tobacco and coffee, and work the best goldand silver-mines in Sumatra.

The Korintjis, who inhabit the country surrounding Indrapura, and are reinforced by the Malays of Menangkabau, form a smaller group than the Redjangs; but they are even more warlike than the latter, and far more difficult to handle. The majority are Musulmans by name, but animists in fact.

The Orang-Ulu and the Orang-Lubu of Mount Ophir are savages; near relatives of the Batiks; peaceable and extremely poor.

The Malays of the seaboard and the Malays of Menangkabau ${ }^{x}$ represent the pure Malay element in Java. The Malays of the seaboard closely resemble those of Malacca and of Riouw-Lingga; they live chiefly in the country of Palembang, the centre of the trading highways of the island.

The Malays of Menangkabau (Dutch, Menangkabau Maleiers) regard themselves as the primitive Malays. It is more probable that they are a detached branch of the Malays of the coast, which has been isolated for ages in the interior of the country, and has developed in perfect independence. The kingdom of Menangkabau, says the native legend, arose upon the ruins of

× A kingdom now extinct. It was situated between the kingdom of Palembang and the Siak River on the east; between the kingdom of Mendjuto and the Singkel River on the west. 


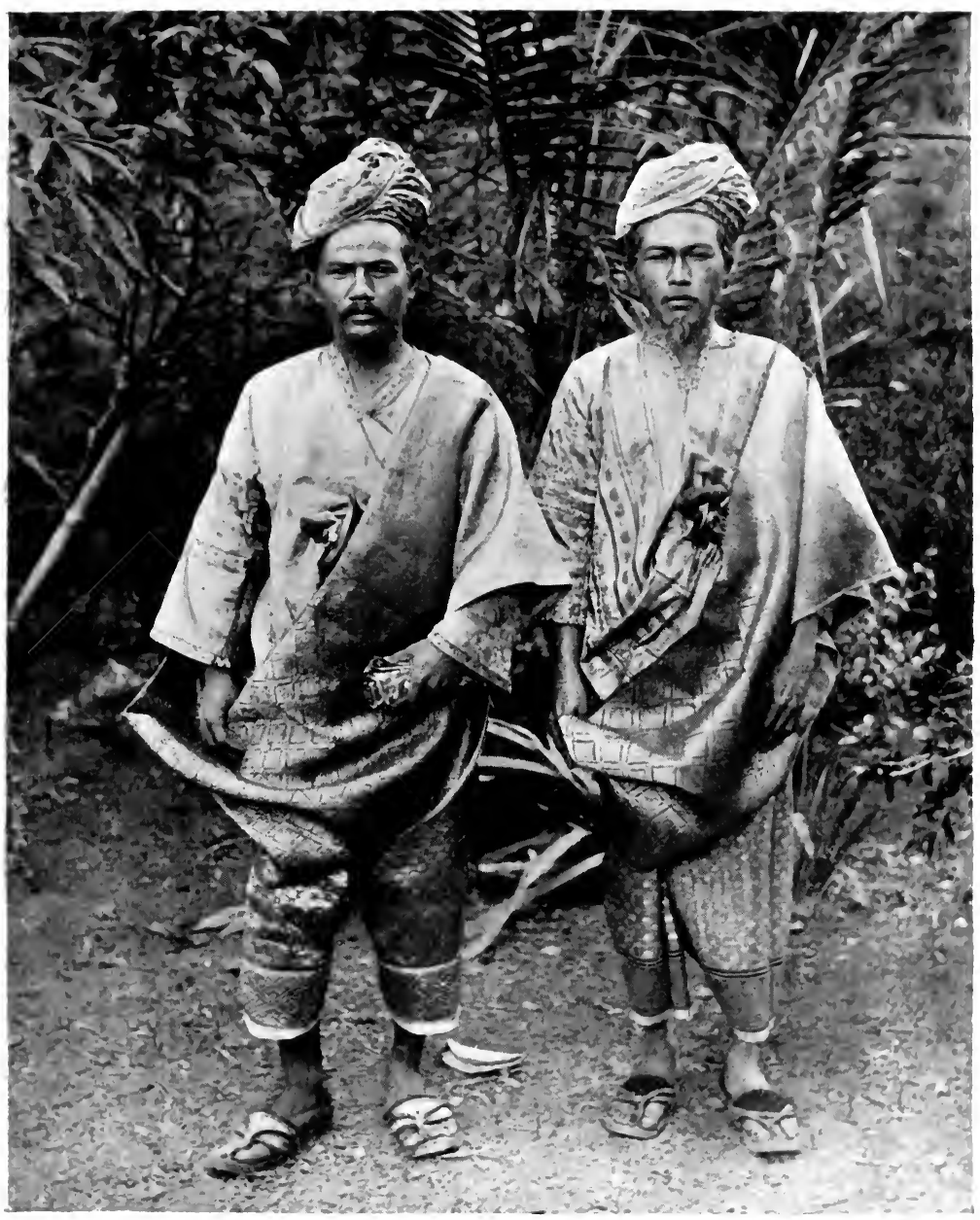

MALAYS OF MENANGKABAL, KOTA GEDANG. 

the Hindu empire of Adityavarman, and its name, "Victory of the Buffalo," symbolised the supremacy of Sumatra and the Malays over Java, which they are supposed for a time to have conquered. Early converted to Islam while preserving their own adat, the Malays of Menangkabau regard themselves as the best Mahomedans in the Archipelago.

Marriage with them is always exogamic, and has retained the matriarchal form. The husband cultivates the soil for the wife, who owns it as she owns her children; the property of the father passes to the children of his sister, not to those of his wife or brother.

It is true that contemporary observers represent the Malay of Menangkabau as possessing but little conjugal fidelity; as anything but a sentimental father; as defiant, a born intriguer, avaricious, harsh to his inferiors, servile to his superiors, inhospitable and hostile to the foreigner; a babbler, indifferent to cleanliness, an intemperate drinker and eater, and a desperate smoker and betel-chewer. There is light, however, in this gloomy picture. It must be admitted that the Malay of Menangkabau is industrious, full of endurance, an excellent workman, an experienced trader, and an excellent farmer. $\mathrm{He}$ has not, like the Javanese, a burning desire to educate himself or to improve his position; yet when he does decide to study he does so with the most zealous tenacity. $\mathrm{He}$ has a keen artistic sense and skilful fingers, and executes charming work in glass, filigree, and copper, and is a fine sculptor in wood and sometimes in precious metals. The women share in these gifts, for the kains, the cloth of gold of Ugam, the rich stuffs of Si Lungkang and Simgei Pagou, are greatly valued. They also undertake the milling of sugar-cane and make pottery, but the men only work in the mines, are carpenters and cabinetmakers, build praus, and work in copper and wood.

The Malays of Menangkabau are all Mahomedans, but they are scarcely more zealous than the Javanese : 
yet on occasion their distrustful minds will bring a dangerous enthusiasm to bear upon the question of religion. It was among them that the famous Padris I arose : a sect of reformers, who, in 1820 or thereabouts, in the hope of leading their compatriots back to a stricter observance of the ritual of their faith, rebelled against the Sultan of Menangkabau, who was at the same time priest and king. The latter, despairing of victory, appealed for assistance to the Dutch, who after a sanguinary war of nine years' duration exterminated the Padris, but subdued Menangkabau.

From the social point of view the Malays of Menangkabau are organised into sukus, or clans, the chosen chief of which, who is selected from a privileged family, is always assisted by a council composed of the adult males of the clan. Several sukus form a district, which has for its council the chiefs of the sukus composing it. The district, according to the number of the kotas, or villages, is known as a "district of 20 or 30 kotas."

The Bataks are the Malays of the western branch, who inhabit the Residency of Tapanuli in the south of Atjeh, a large part of the eastern coast of Sumatra, and portions of the neighbouring islands which are external to the Dutch empire properly so called. According to the differences in their dialects, the Bataks are divided into three principal groups : the Tobas of Siboga, Baros, and Sorkam; the Mandailings of the west coast of Sumatra ; and the Dairis of the north and north-west of Baros and the centre of Singkel. To these groups others are related : the TimorBataks, the Raja-Bataks, and the Pakpak Bataks of the Sea of Toba: the Karo-Bataks and the Dusun-Bataks of the high plains and the east coast of Sumatra.

Any real knowledge of the Bataks dates from 1867-

- From the Portuguese padre, in the religious sense of father. Passed into the Malay tongue as padri, this word has come to mean priest or ecclesiastic. The leaders of the Padris' rebellion, who were all members of the Islamite clergy, were at first the sole bearers of this title; but later on it enlarged its meaning, and signified the adepts of the sect as a whole. 


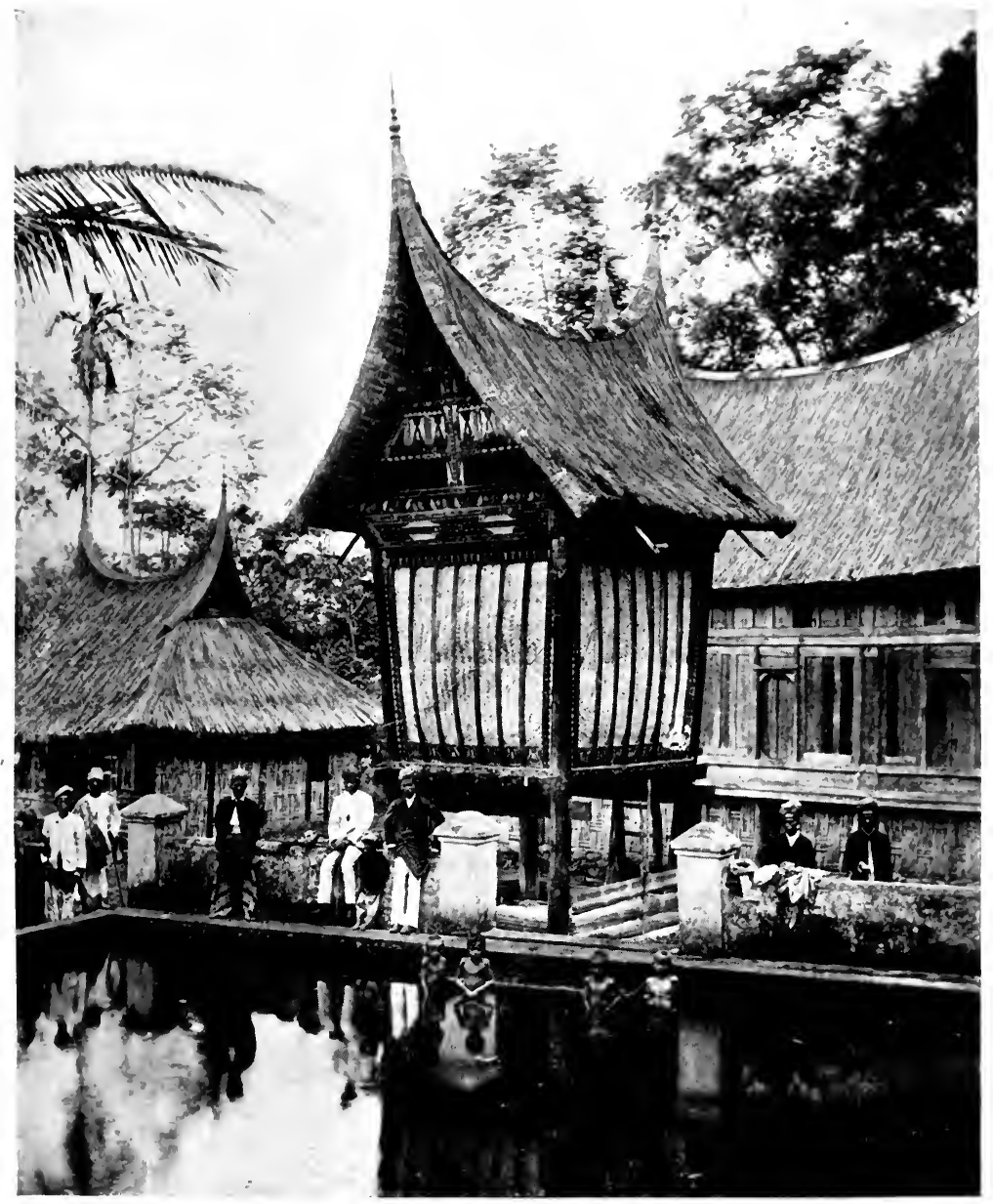

DWELLIG-HOCSE AND) RICE GRANARY, BATIPL, SEMATKA. 

$1883{ }^{x}$ they had at first a terrible reputation for cannibalism, due principally to the reports of ancient Arab travellers; they accused them of eating their aged relations so soon as the latter were no longer of service to them ; in order to give them a pious sepulture in their stomachs. At the season when lemons (the indispensable accompaniment of such a festival) were ripe, the aged victim would climb a tree; the family would dance around below, singing "Where the fruit is ripe it falls from the tree"; until the victim allowed himself to fall, when he was knocked on the head, cut up, and consumed according to custom. ${ }^{2}$ The Bataks were also accused of eating their prisoners of war, men of the people who

'See M. Joustra, Litteratuuroverzicht der Bataklanden (Leyden, 1907, 8vo). A Batak Institute was founded in Leyden in 1909 for the purpose of co-ordinating and encouraging the study of the Batak peoples.

2 It is usually considered that the victim of anthropophagy must be unwilling. We may take this unwillingness for granted in the case of shipwrecked strangers, prisoners of war, and missionaries not of the stuff of martyrs; but in such cases as the above (which if not true of the Bataks is true of many cannibals) it is more than probable that the moribund would object to any other end. Indeed, it is not difficult to understand that the rite might have originated not with the eaters, but with the eaten. It is conceivable that a savage who had lived a full and warlike life would regard with abhorrence the dispersal of his remains by decay, which in an early stage of animism would by some be regarded as annihilation. Consumption by the family, on the other hand, might well be accompanied by a conception of immortality. The old, helpless man, with the joys of life failing him, would find a certain attraction in the idea that his body would become part of the strong brown bodies around him. He might even have a dim conception that he would be partly conscious in each of his sepultures : an idea by no means far-fetched, but borne out by the fact that the old were eaten to partake of their wisdom, and fallen warriors to partake of their strength. Chance shipwrecked mariners were doubtless disposed of with the thrifty idea of saving any virtues they might possess. In Africa, if a crocodile eats a man, the crocodile is afterwards regarded as the deceased; if the deceased were ill-tempered the crocodile is greatly feared. Cannibalism may become degraded and hypocritical, but must not in itself be regarded as a proof of low civilisation.-[Trans.] 
committed adultery with the wife of a chief, foreigners and strangers suspected of hostile intentions, \&c. The Bataks, who to-day are Christians or Islamites, deny these practices with indignation, or refer them to a period very remote; and it seems established, by the study of selected cases, that the Bataks were not actually cannibals, but that they practised ritual killing and the symbolic consumption of the victim's flesh.

Out of 500,000 Bataks about I25,000 are Mahomedans, although the propaganda of Islam followed rather than preceded that of Christianity. They number 80,000 Christians; the remainder are animistic pagans, whose beliefs are modified by very vague memories of Hinduism. These latter are susceptible to Christian influences: a fact which has greatly facilitated the access and the domination of the Dutch. Their character is peaceable and easy : they are farmers and breeders of cattle, and terminate the labour of the rice-fields by collective banquets, at which many buffalo are consumed, with kids and even pigs for the Christians. Whatever religious label the Batak assumes, he is a superstitious person rather than a believer; the Islamism of the Bataks, wherever it is professed, is limited to circumcision, which rite is also practised by the pagan Karo-Bataks; abstention from strong drink, and from the flesh of the pig; the veneration of Hadjis and santris, and the erection in almost every village of a very countrified-looking mosque. In everything else the village adat comes first. The practice of filing the teeth is general : marriage affects the partriarchal or the matriarchal form according to the village in question or the rank of those concerned.

The houses of the Bataks are of a neat rustic type, their graceful roofs recalling those of the Bahnars of French Indo-China, as does their great communal house, where they receive friendly strangers and keep their most valued possessions, which are generally of a fetishistic nature.

A few manuscripts upon wood or palm-leaves, traced 
in an alphabet of Hindu origin, prove that the Bataks once knew a civilisation more advanced than that they enjoy to-day. ${ }^{\mathbf{x}}$

The Gayos, thanks to the masterly study by Dr. Snouck Hurgronje, professor at the University of Leyden, are better known than the Bataks. The country of the Gayos is situated on the western coast of Sumatra, between the Straits of Malacca and the Indian Ocean, but does not at any point touch the sea; it is isolated by a long belt of Achinese territory which with the Alas and Tannang provinces completely surrounds it, except upon the south-eastern frontier. In spite of some differences of type and dialect, which vary with their habitat, the Gayos present a real chronographical unity, and a rudimentary civilisation slightly superior to that of the Bahnars and the Stiengs of French Indo-China, and on about the same level as that of the Chams of the same country.

The principal event of the religious life of the Gayos, who are all Islamites, is the rite of circumcision, which is practised by an accredited operator towards the eighth or tenth year. They also celebrate the mulud, or festival of the Nativity of Mahomet. In the large villages the fast of Ramadhan is better observed than in Java. Even the opium-smokers abstain for a few days. In the smaller villages the feast which closes the fast is the principal affair.

The Gayo contrives to mingle the family adat with the influence of the Koran. Both sexes file the teeth. Marriage is patriarchal compared with the marriage of the Malays of Menangkabau. The woman can only leave her village for the pilgrimage to Mecca, which a woman scarcely ever makes; the family is perpetuated through the males, and in default of a son the Gayo will often adopt his son-in-law, or a stranger, who is nearly always an Achinese, a Malay, more rarely an Arab, a Malabarese

$\therefore$ The Bataks have special languages for women, thieves, and sorcerers, and a "language of leaves": the latter for the use of fiancés. 
or a Chinese; but he is always adopted upon the condition that he becomes a Musulman. The funerals are according to the Musulman rite, excepting certain superstitious practices, such as removing the corpse by a special opening, instead of by the habitual stairs or ladder.

The Gayos enforce the excellently moral custom of causing all the boys and young men to sleep in the common house up to the time of their marriage. Like all the Indonesians, they have retained a superstitious belief in good and evil spirits, and seek to conciliate them by means of oblations and prayers which are repudiated by the orthodox Mahomedan.

The Gayos accompany all their festivals with kunduris, or banquets, to which a religious colour is given by the recitation before meat of passages from the Koran, and the presence of men of piety; so that these banquets remind one strongly of the slamettans of Java. ${ }^{x}$

The Achinese inhabit the kingdom of Acheen in the north of Sumatra $(582$, I 75 inhabitants, of whom 76 I are Europeans, 875 Chinese, I,26I Oriental foreigners, and Ior Arabs), which they reckon as bounded on the east by Tamiang and the west by Baros. ${ }^{2}$ The territory, which will soon go the way of that of the Sultans of Menangkabau, comprises a stretch of country in the north which the Achinese regard as Acheen or Atjeh proper, and which the Dutch have called Great Atjeh (Groot Atjeh). This portion is shaped precisely like a fan, the mouth of the river Atjeh marking the point of the fan, where the impurities of the rice-fields collect. It comprises, to the left, the Twenty-five Mukims; 3 to the right are the Twenty-six Mukims; the Twenty-two Mukims occupy-

× See C. Snouck Hurgronje, Het Gajolund en zijne bewohnen (Batavia r9o3, 8vo illustr.).

2 Other names of Acheen are: Atjeh, Acheh, Atcheh, Achin, Acheen, Achem, \&c.

3 The mukim (Dutch form moekim; an Arab word) is a territorial subdivision under the authority of an imaum, and corresponds more or less to the English parish. 
ing the wide belt of borderland. These three confederations have received the name of the "Three Angles of Atjeh," and the chiefs who preside over them are the "Heads of Atjeh."

The Achinese also have been the object of a lengthy study by Professor Hurgronje, whose profound understanding of Islam and the Islamitish Insulindian nations has enabled him to write a work containing most important information, whose conclusions have more than once been a guide to Holland in her interminable struggle with the Achinese. ${ }^{\mathbf{I}}$

The Achinese claim to be of Hindu origin. It is eminently probable that they were converted to Islam by the Hindus, and that their race has received additions of Dravidian, Malay, Bugis, Arab, and even Egyptian origin. The kingdom of Acheen boasts of its foundation in the thirteenth century by a Sultan descended in the direct line, as are almost all the Malay princes, from Iskander or Alexander the Great. It is certain that at the beginning of the seventeenth century the Sultan ruled over half Sumatra and the small neighbouring islands; that he had permanent relations with Turkey and China, Egypt and Japan; but in the eighteenth century the kingdom declined. We can understand that with such memories as these, and a somewhat bellicose temperament, the Achinese, although now deprived of ninetenths of their ancient territory, have but unwillingly accepted the Dutch rule, against which they have been desperately struggling since $\mathbf{1 8 8 3}$, even though all the towns and important strategic points of their countrySigli, Edi, Kota Radja, Oleh-Leh and Sabang, are occupied by the Dutch soldiery.

The Achinese, accordingly as they live in the mountains under the name of Orang-tunong, or in the plain under the name of Orang-baroh, exhibit characteristic differences. The former are the more warlike and are frequently fanatical ; they hate the foreigner, are incor-

'Dr. C. Snouck Hurgronje, The Achehnese (Leyden, 1906, 2 vols. 4to). 
rigible brigands, and think nothing of robbery or murder ; the people of the plain, of a more peaceable nature, and accustomed to international relations, have in an exaggerated degree, it is said, the usual faults of the Malays: treacherous flattery, servility, intemperance, the abuse of opium and of strong liquors.

Among the Achinese, as among nearly all the Mahomedan Sumatrese, we find the coexistence of the power of the adat and of the religious law.

The woman is married very young, at eight or ten years of age, the boy being from sixteen to twenty. The marriage is arranged by go-betweens, and is of the patriarchal type, the woman receiving a betrothal present as well as her parents. The ceremony is celebrated after the Arab fashion, in spite of various additions which have no relation to Islam. The husband works for a certain period with his parents-in-law, in order to compensate them for the loss he is causing them; the marriage contract also stipulates that the husband cannot separate the wife from her parents without her consent.

A nuptial gift to the wife, after the consummation of the marriage, is obligatory; according to the wealth of the husband it may be of gold and silver, and consist of a necklace or a bracelet.

It should be noted that the chief of the kampong has the right to oppose any marriage that may appear to him contrary to the peace or security of the tribe; it is he who fixes the most favourable day and hour for the wedding.

The maiden of good family marries only among her equals; never a foreigner, unless an Arab, a Malabarese, or a Komitji, wealthy and well versed in sacred things. Other applicants can only obtain the descendants of slaves. The Achinese are Musulmans, often fanatical towards foreigners, but nearly always lukewarm in the practice of their religion. They do not, of course, omit circumcision, but their women are not veiled, any more than are the women of Gayos, Bataks, or the Malays. They celebrate the mulud, which is perhaps their 

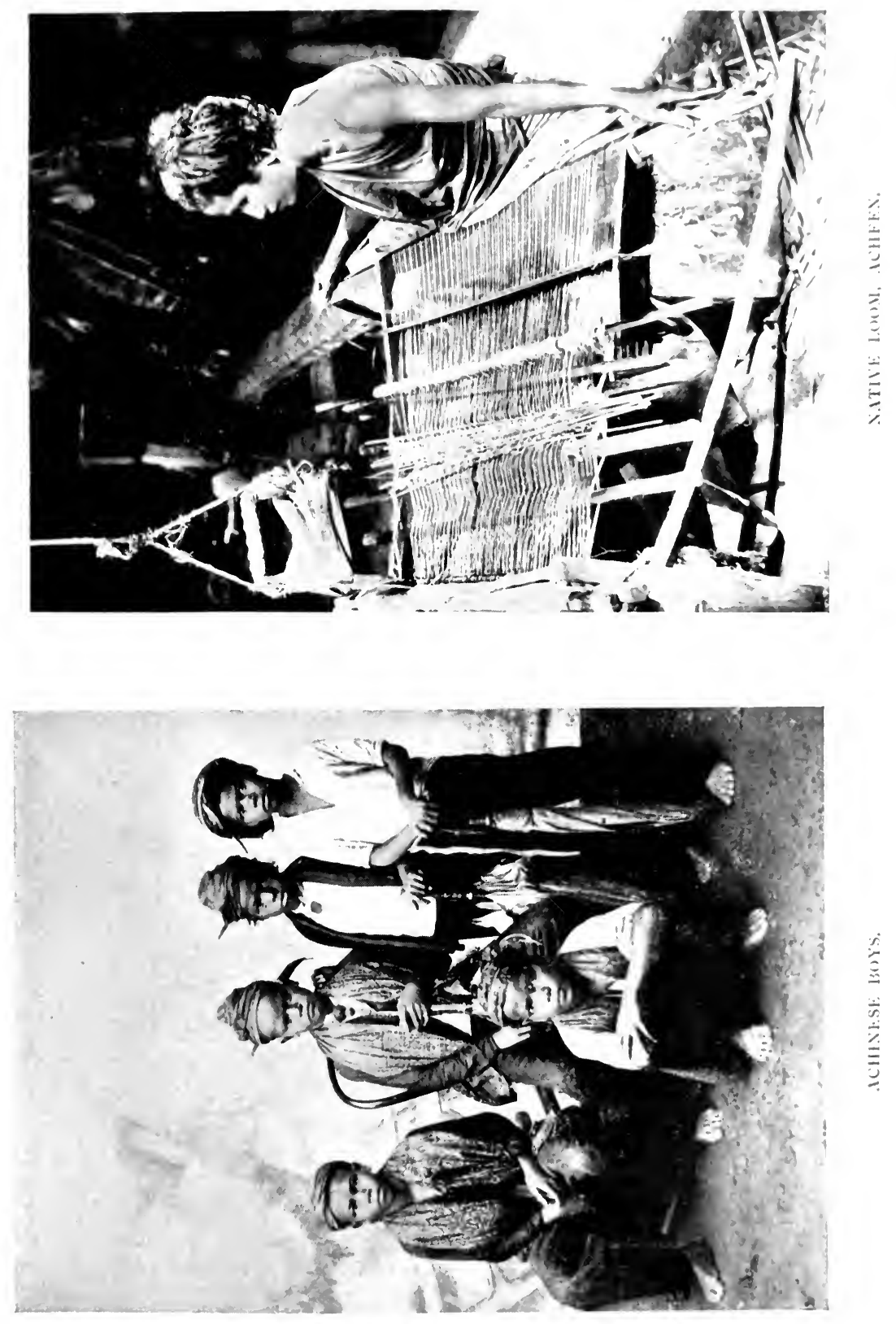



\section{SUMA'TRA AND RIOUW LINGGA 277}

greatest festival ; and also the closing feast of Ramadhan, but very few strictly observe the prescribed fast. Many content themselves with fasting three times a month-at the beginning, in the middle, and at the end-and very few abstain from smoking tobacco during the period of penitence. To the Achinese, as to the Gayos, the Malays, and the Javanese, the religious festivals are excellent occasions for banquets, which are known in Acheen as kanduris. They are opened by a prayer, or the recitation of passages from the Koran; and consist of dishes of a determined quantity and quality. The most solemn of these kanduris is that of the mulud; but the Achinese hold banquets upon all excusable occasions. Recovery from illness, or falling sick; sending a son to school; returning from a voyage; the success of a stroke of business; the threat of an enemy; a bad dream; all such trifling events may be so celebrated.

The islands which cluster about Sumatra are peopled by various races, according to their geographical position.

The northern islands in particular have been peopled by emigrants from Menangkabau and Acheen ; but Bangkan remains deserted, because it is supposed to be the refuge of evil spirits.

The Niassais, inhabitants of the Nias Islands, are Malayo-Polynesian by race, and number some 240,000 . They live sociably in villages; they are gay, and hospitable of aspect, but their moral standard cannot be called high. They are born thieves, hypocritical, cowardly, and cruel, and are constantly waging war between village and village, between family and family, and carrying on interminable vendettas.

Farmers and fishermen, they live on rice, maize, sago, and coco-nuts, to which they add, at their banquets, fowls and pork and large quantities of palm wine. They are inordinately fond of dress and ornament; the ceremonial costume of a chief is often worth $£ 240$ to $£ 320$, and that of his wife nearly half as much. They do not dice, neither do they smoke opium.

Good craftsmen, they weave, dye, and colour stuffs and 
matting, work in copper, make arms, and build fairly presentable houses, which are, however, exceedingly filthy inside. The interior of the house is often decorated with the tusks of boars, or even with human skulls. Their women, who are well built, are greatly sought by the Malays.

The religion of the Niassais is a rudimentary animism, fearful above all of evil spirits, or badjus, and of Nadaya their chief. These spirits are propitiated through the priests and priestesses, who form a special but not a privileged class.

Extremely superstitious, the Niassais fear and maltreat albino children, although the latter are very numerous; twins they kill, and the funerals of chiefs are often accompanied by human sacrifices. Each house has its household god, in the shape of a puppet carved in wood; in this the souls of the ancestors of the household are incarnate, and it also protects the hearth. The Niassais never move without taking their idols with them; they also honour the phallus carved in wood, and the village has its protecting deity, with his wife. These, which are also of wood, are placed at the entrance to the village so that they may watch over its safety.

Although the family is so poorly constituted among the Niassais, adultery and seduction are punished by death.

The Niassais are now beginning to emigrate to Sumatra, in order to make money as carpenters, masons, labourers, \&c.

The islands of the volcanic archipelago of Mentawei are inhabited by a population of about twelve thousand persons, who in many points resemble, according to Rosenberg, who spent six months among them, the natives of the Marquesas Islands of Hawaii, a finelooking, gentle race, their code of morality is very inflexible; they know nothing of divorce, and punish adultery by death. Men and women have the whole body tattooed in childhood; they deck the head and the ears with flowers in the Polynesian fashion. Their religion consists chiefly in a fear of the evil spirits that 


\section{SUMATRA AND RIOUW LINGGA 279}

people the universe, and also the souls of the dead; but they do not offer them sacrifices of any notable value. They have neither temples nor figures of the gods; they make their rare oblations in a special corner of the forest. Certain meals are forbidden to the women. They live by hunting and fishing, and, to a certain extent, by agriculture.

The group of islands which the Portuguese called the Engano, or Deceitful Islands (engano signifying "deception," "illusion"), consists of one principal island, Keifu Kaikukka or Eloppo, and six small islands, all of which are surrounded by dangerous reefs. This little archipelago is of no economic importance, and is only occasionally visited by the Dutch officials. The inhabitants, who are tall and of a bronze-coloured complexion, are accustomed to go naked, hence the name of Pulu Telandjung, meaning "Island of the Naked," which the Malays have given their group of islands. They practise a primitive animism. Their numbers are steadily decreasing : they were 3,000 in 1862 , and only 692 in 1893 ; to-day there are scarcely 6oo. The Engano Islands are under the administration of the Resident of Bencoolen.

The islands of the east coast of Sumatra are much larger and of much greater geographical and economic importance than those of the west coast. They include the archipelago of Riouw Lingga, with the small islands lying between Borneo and that archipelago, of which they really form outlying fragments. Further to the south of Sumatra are the two large islands of Bank and Billiton.

The archipelago of Riouw Lingga, to the south of the Malay Peninsula, is a granitic prolongation of the latter : although the alluvial deposits of the rivers of Sumatra are tending to unite it with the mainland. Although its total area is greatly superior to that of Singapore, its population in 1909 amounted only to II 2,216, of whom 22I were Europeans and 18,49I Chinese.

The archipelago of Riouw Lingga is composed of two groups of islands : the archipelago of Riouw and Lingga, properly so-called, and the Pulu Tudjuh islands. 
The archipelago of Riouw Lingga consists of some hundreds of little islands, which have been divided into five subsidiary groups: the Karimon, Batam, Bintang, Lingga, and Singkep groups. All these islands are granitic and covered with undulating hills, of which the highest, the peak of Lingga, rises only 4,400 feet above sealevel. The island of Lingga also contains the largest alluvial plain in the archipelago.

Singkep, mountainous to the north-west, is full of swamps about the centre.

The rivers on islands so limited in size, are necessarily insignificant. The climate of the archipelago is almost everywhere excellent, the heat being tempered by the abundant rains, by the ocean currents, and the surrounding sea. Almost the entire archipelago is covered with a luxuriant vegetation; teak, trees secreting various gums and resins, palms of many varieties, anana and bananatrees, sugar-cane, all grow readily and without attention.

The fauna, as varied as the flora, and able to hold its own with that of Java or Sumatra, has one appreciable virtue: it contains no dangerous carnivoræ.

The natives, known as the Orang Benua, who are poor and peaceable, are of Malay origin; their race being a mixture of pure Malays, Bugis, and Chinese.

The landscape of the archipelago, with its bold contours, its luxurious vegetation, and the play of the sunlight upon the all-encompassing sea, is the admiration of all travellers privileged to behold it.

The Pulu Tudjuh group, which includes more than three hundred islands, large and small, lies to the south of the China Sea, between the Malay Peninsula and Borneo. It has been divided into seven sub-groups, the Anambas counting as two; the Natunas as three; the Ilanung or Lanung (isles of the pirates or Lanons, in Dutch the Zeerovers-Eilanden) as one, and the Tambelans as one.

The Natuna Isles number fifty-five at least, and are mostly of granite formation. The largest, Bunguran, contains a thousand inhabitants: Orang Lant, Malays, and Chinese, who live by their fisheries, and their coco- 


\section{SUMATRA AND RIOUW LINGGA 281}

palms. The others contain only fourteen hundred souls altogether, who are still more poverty-stricken than the folk of Bunguran.

The ninety-six little islands, wooded and mountainous, which form the Anamba group, are peopled by some four thousand inhabitants : Mahomedan Malays or pagan Orang Laut. They cultivate the sago-palm and the coconut ; they fish, build praus, and export a little building timber to Singapore.

The forty rocky islands of Tambelan support about a thousand inhabitants between them. These are nearly all Malays, who live by fishing, the culture of the coco-palm, and the sale of swallows' nests.

Banka, or Bangka, and Billiton are far their superior in area and in economic value, and each forms a separate administrative division.

Banka, a granite outcrop detached from the Malay Peninsula, is situated off the east coast of Sumatra, from which it is separated by the Strait of Banka. A mountainous island, with an area of 4,460 square miles. The highest point, Mount Maras, is only some 2,000 feet in height. The island slopes towards the east to a sandy seaboard; on the west is a shore of swamps.

Its rivers are numerous and abundant, though short. The two largest are the Sungei Selan, which is 18 miles in length, and the Djerin, on the west, whose outlet is more than $\mathrm{I}, 000$ yards in width.

The climate of Banka, like that of Billiton, is extremely hot, but is tempered by the proximity of the sea. It is also very variable, reaching $100^{\circ} \mathrm{Fahr}$. in the shade on the plains, while in the higher altitudes it may fall as low as $39^{\circ}$ or $41^{\circ}$ during the night.

Banka is verdant with a vegetation resembling that of the Malay Peninsula; its fauna, which partakes of that of Sumatra and that of the Peninsula, includes no carnivora excepting the little brown Malay bear (Ursus malayanus Raff.); but serpents and crocodiles are by no means unknown.

Its inhabitants, to the number of 115,190 , of whom 
43,720 are Chinese, 3I7 Europeans, and 26I Arabs, are -we are speaking of the natives-descendants of the Malays of Palembang. They live in a semi-savage condition, by their groves of coco-palms, areca-nut trees, areng-palms, bananas, and their potatoes; and to some extent by fishing and the chase. Poor and ignorant, they hold aloof from the foreigners who visit their island to exploit the abundant mineral wealth beneath its surface, and who set them the example not only of a healthy activity, but also, in most cases-and this is true especially of the Chinese miners-that of a host of repulsive vices.

Billiton, or Blitung, to the south-west of Banka, has an area of $x, 860$ square miles, and a population of 36,860 , of whom 2,520 are Chinese, 136 Europeans, and 16 Arabs.

In its physical aspect and geological constitution it resembles Banka. Its highest point, the hill known as Tadjam, is only some 1,600 feet above sea-level. It is watered by a number of short streams; at the mouth of one of these, the Tjarutjup, in the east of Billiton, is built the chief town and capital of the island, Tandjong Pandang.

As in Banka, the natives do not work in the mines. They cultivate a few fields and the more valuable kinds of palms; they also weave mats and make vessels, \&c., of pewter. They export a little copra, also baskets, rattan, gums, and resins, wood for furniture, and tortoiseshell.

\section{VI.}

The languages and dialects of Sumatra are as numerous as the races of its inhabitants, despite the visible relationship of both. The principal languages are the Malay of Menangkabau, Batak, Achinese, Lampong, Redjang, Lebong, \&c. Malay, the usual language of the whole of the east coast, excepting the two extremities of the coast, of the archipelago of Riouw Lingga, of Banka, Billiton, and the greater part of the west coast, is also understood and spoken by all the other peoples of Sumatra ; it serves as the language of trade and inter-tribal communication in all parts of the island. 


\section{CHAPTER XIV}

THE POLITICAL AND ECONOMIC CONDITION OF SUMATRA AND THE ARCHIPELAGO OF RIOUW LINGGA

I. The Dutch have been hampered by certain European Powers and certain of the races of Sumatra in their endeavour to establish the power of Holland in Sumatra.-II. The present administrative divisions of Sumatra.-The principal towns and their future.-III. Economic value of Sumatra : the wealth of its natural resources.-IV. How far the natives have exploited the natural resources.-V. How far the Europeans have done so: the mines.-VI. Coffee and tobacco; spices.-VII. The means of communication with Sumatra : railways, packet-boats. -The means of communication must be greatly enlarged before the island can be pacified and its wealth developed.

I.

SumATRA, ${ }^{x}$ it seems, has only been known to the Europeans since the sixteenth century; long after the Hindus, and later on the Arabs, had brought their beliefs and their civilisations. The imprint of the Hindus remains especially visible in the east and south of the island; and that of the Arabs in the north and along the eastern coast. Ludovico di Varthema, 2 the first of the Europeans, is said to have discovered the coast of Sumatra in $5^{\circ} 5$. He was followed by the Portuguese in 1509 , and in 1599 by the Dutch, who landed on the coast of Achin. Here Cornelius Houtman, one of those who "discovered" for

"Other names of Sumatra: Malayu, Java Minor, Al-Râmni, Samara, Sumadra, Shamudra, Shamuthera, Soumatra, Andelas, Pulo Pertja, Liman, \&c.

- See Les voyages de Ludovico di Varthema ou le Viateur de la plus grande partie de l'Orient. Published by Ch. Scheffer (Paris, I89o, 8vo.). 
Holland the route to the Indies, was killed by the Achinese (I599), who began, over the body of the representative of the power of Holland in the East, their interminable struggle against that Power. Having gradually won a footing upon various points of the Sumatrese coast, and having expelled their predecessors, the Portuguese, the Dutch were compelled throughout the whole of the eighteenth century to struggle against the rivalry of England. Only in I8I4 did England renounce her claim to Banka in return for the cession of Cochin and its dependencies on the Malabar coast ; and in I824, by the Treaty of London (confirmed and amplified in $187 \mathrm{I}$ ) she abandoned all claims to Billiton and the whole of Sumatra, in return for all the remaining Dutch possessions on the Indian coast and the Malayan Peninsula, together with the island of Singapore.

Her European rivals being thus disposed of, Holland set herself the arduous task of rendering her domination actual instead of nominal, as it was at the beginning of the nineteenth century. The size and configuration of the island, and the independent spirit of its peoples, have made the task a matter of interminable patience in which diplomacy has more than once been forced to fall back upon the force of arms.

The country of the Lampongs, formerly under the suzerainty of the Sultans of Bantam (Bantan, Banten), was in 1808 annexed by Daendels, after an expedition against Bantam itself. Since then, with the exception of a formidable rebellion in 1850 , the country has been quiet. The territories of the Redjangs and the Lebongs, who were recognised vassals of Holland, shortly afterwards made a show of hostility, and murdered some European agents, with the result that they were incorporated as part of the Dutch domain in 1858 .

The wealthier and more desirable eastern coast was acquired with far greater difficulty. At the beginning of its power the East Indian Company sought by various means to gain a modest footing in order that it might extend its trade; then, profiting by the constant quarrels 


\section{SUMATRA AND RIOUW LINGGA 285}

of all the reigning princes, and by offering its aid first to one and then to another, it gradually contrived to subject them, or, if need were, to suppress them altogether. Wherever it was possible without endangering their domination to maintain the ancient institutions of the country they established them by law. The shadow of a Sultan, generously pensioned, but without any initiation, has in more than one case proved to be a diplomatic instrument of authority over these obscure and fanatical races. Thus the Sultans of Djambi and Deli were retained upon their thrones.

The powerful kingdom of Palembang was one of the first which the Dutch sought to enter, on account of its enormous production of pepper. In I6I7 the East Indian Company obtained access to the Sultan; and in I620 the foundation of a modest settlement enabled it to drain the country of pepper for the benefit of Batavia. In 1654 violent hostilities broke out against the Dutch, who were forced to leave the country: they returned in force and captured Palembang. In 1659 the Sultan was forced to grant them the monopoly of pepper, and permission to build a fort upon the Musi. In I8I9 another rebellion again ended in the expulsion of the Dutch. One of the principal causes of this misunderstanding was the fact that the two rival Powers were disputing for the possession of Banka and Billiton and their rich tinmines, of which the Sultan of Palembang was the pretended sovereign ; but in reality the prince of the islands in question had in 1668 placed himself under the protection of the Dutch East Indian Company, which fact enabled the Dutch Government to establish itself on the two islands. An expedition led by De Kock in I82I against Palembang subdued the latter. In 1825 the city attempted to rebel, and was again taken; in 1849 a Resident was installed there. In 1864 it was judged ripe for European government; and save for a rebellion fomented by fanatical Mahomedans in I88I, the city and the whole country are perfectly tranquil, and to-day seem contented with their lot. 
The Sultanate of Djambi showed itself even more antiforeign than Palembang; with the result that the Dutch, unwilling to see their compatriots who went thither to trade assassinated, broke off all relations with the Sultan. In I883, however, a Sultan of Djambi requested the Dutch to help him against the pirates. By means of their assistance he was victorious; but in return the Dutch established a small garrison in his capital, and he was obliged to grant the right of free trade and the monopoly of salt. In $185^{8}$, these concessions being revoked by a new Sultan, an expedition seized his kraton, drove him away, and replaced him by one of his uncles, who was of a more accommodating temperament. The latter recognised the suzerainty of Holland, which appointed a "political agent" in permanent residence at his court. In 1868,1878 , and $188 \mathrm{I}$ serious difficulties arose, and ended in the more definite mastery of the Dutch Government, which compensated the Sultan for his decreased authority by an increased pension. The assassination of three Europeans by two Hadjis, in I883, several outbreaks of discontented natives, which met with the approbation of the Sultan, in I886, I888, and again in 1895 , have reduced the power of the Sultan to a vain appearance. Every three months he is obliged to present himself before the political agent, and, although his movements are unrestricted, they are none the less carefully watched. All monopolies are retained by Holland, as well as the effective exercise of power.

Holland having, in 1824, annexed the archipelago of Riouw Lingga, in order to expel a non-Malay Sultan who was protected by the English, the Resident of Riouw, in I872, profited by that fact in claiming, in the name of the Sultans whom his predecessors had replaced, the suzerainty of the kingdom of Siak, on the east coast of Sumatra, it being at that date in a weak and unstable condition.

The subjection of the Sultanate of Deli, further to the north, was a matter of more difficulty; but in 1854 the Sultan, who had succeeded at one stroke in emanci- 


\section{SUMATRA AND RIOUW LINGGA 287}

pating himself from the princes of Siak and Achin, demanded aid from Holland against renewed pretensions on the part of the Achinese. In $185^{8}$ he became the vassal of the Dutch Government; in 1872 there was a brief rebellion, and in 1876 Deli was taken over by the government of the east coast of Sumatra, although the Sultan is retained upon the throne.

As for the west coast, upon the withdrawal of the English the Dutch found themselves masters of only a narrow belt of territory, with Bencoolen as its capital. The wealthy interior, the Highlands of Pandang, remained closed to them, as did the mysterious kingdom of Menangkabau, the centre of the Malay power, the Maharajah of which boasted, in his letters, that his authority extended from China to Turkey.

In $182 \mathrm{I}$ this Maharajah, or emperor, who was also the high priest, the supreme pontiff of his country, begged the assistance of the Government at Batavia against certain of his subjects, the fanatical Mahomedans known as the Padris, of whom we have already spoken, who wished, in the name of the Koran, to abolish the adat, and everything in the social and political organism that was not in conformity with Islam. They also protested against the abuse of tobacco, opium, and alcohol, and manifested their reforming zeal with arms in their hands.

Holland was forced to fight against the Padris for seventeen years. Once victorious $(1838)$, she wished to annex the territory conquered; no easy matter, since the sovereign of Menangkabau was accustomed to the veneration of his subjects, but not to their obedience; and a whole system of feudatory princes who nominally owed him obedience took independent action and opposed the power of Holland. Only in 1899 was the kingdom of Menangkabau annexed to the Dutch domain and effectually pacified.

In the case of the Batak territory, the influence of the missionaries from 1883 onwards greatly facilitated the establishment of the Dutch power.

It was the conquest of the northern portion of Sumatra 
-the kingdom of Acheen-that gave Holland the greatest trouble. As early as 1509 the Portuguese had endeavoured to enter into relations with the Sultan of Atjeh; in 1601 the Dutch in turn had obtained his permission to establish a factory; but in a revulsion of feeling common enough in these savage and arrogant monarchs, they were expelled in 1616 , and the kingdom remained hostile throughout the seventeenth and eighteenth centuries. In 1816, under the English domination, Raffles avenged the Europeans: he deposed the Sultan and enforced a treaty of commerce. After the withdrawal of England the Dutch, in 1827, again attempted to form relations with Acheen; in 1857 , after endless trouble, they succeeded in obtaining a commercial treaty. The aversion inspired by Holland increasing with her power in Sumatra, she decided, in 1873, to make war upon Acheen. This was an interminable campaign: a guerilla war; an affair of ambuscades and surprises, in a country imperfectly known, interspersed with brief and ineffectual truces or remissions: a war which has already, it is estımated, on one side or the other, cost more than 200,000 lives, and which has certainly cost Holland nearly $f 40,000,000$. Although the neighbouring countries of the Gayos and the Alas were annexed in 1904, and all the important towns and strategical points of the kingdom are now in the hands of the Dutch, the war still continues; desperate, full of treacherous ambuscades; a campaign in which Europeans will not willingly serve. The armed forces which are always in the field have largely contributed to the slight deficit in the budget of the Dutch East Indies. As a result of its obstinate resistance Acheen has lost its native government, and is now under the authority of a military commandant, and will so continue until completely pacified.

\section{II.}

In the still precarious conditions of the Dutch empire in Sumatra, Holland has divided the great island into six 


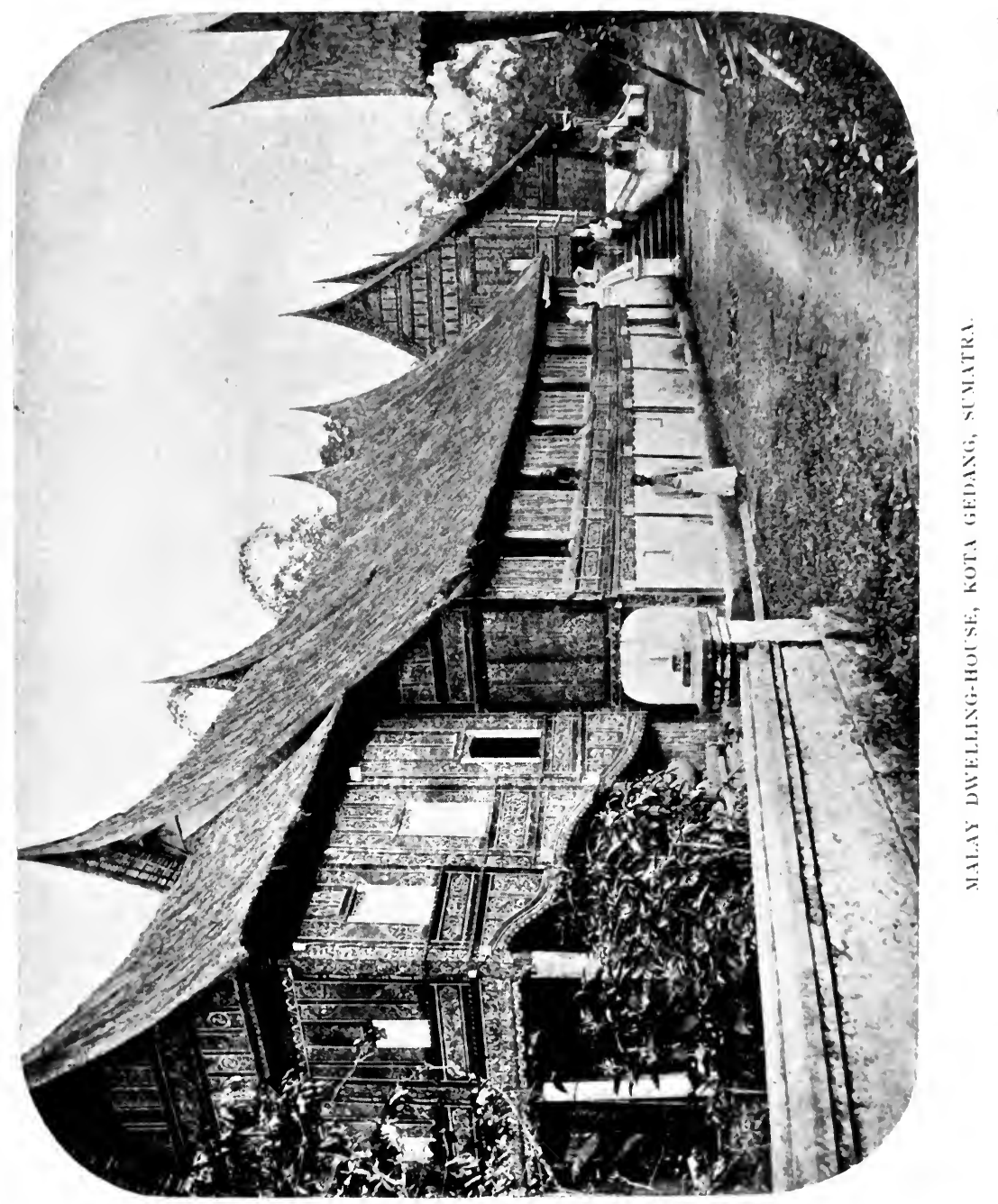





\section{SUMATRA AND RIOUW LINGGA 289}

Governments or Residencies. The boundaries of these divisions by no means always coincide with the old native boundaries, their character being purely strategical or economical, and intended to remould the native life upon a new basis, so that it may be in close touch with the Dutch domination.

The Residents of Sumatra, several of whom bear the style of Governor, are noted among all the Dutch colonial officials as picked men of unusual ability. They have more authority than other Residents; they have greater difficulties to cope with, and their duties are often doubled by the fact that they must act as skilful diplomatists upon occasion; their situation compels them to a greater initiative, demands greater tact and authority than are required of the majority of Javanese $\mathbf{x}$ Residents, who are a trifle spoiled by their comfortable and conventional semi-royalty.

Sumatra contains six principal Governments or Residencies :-

I. The Government of the West Coast of Sumatra (Gouvernement Sumatra's Westkust), which itself consists of the three following Residencies :-

(a) The Highlands of Padang (Padangsche Bovenlanden), the capital being Fort de Kock, placed under the direct authority of the Governor ;

(b) The Lowlands of Padang (Padangsche Benedenlanden), capital Padang;

(c) The Residency of Tapanuli, capital Padang Sidempuan.

2. The Residency of Benkulan, capital Benkulan.

3. The Residency of the Lampong districts (Lampongsche Districten), capital Telong-Betong.

4. The Residency of Palembang, capital Palembang.

5. The Residency of the East Coast of Sumatra (Oostkust van Sumatra), capital Medan.

6. TheGovernment of Acheen(Atjeh), capital Kota Radja.

- As a rule the Dutch Government tests the value of its future Residents by appointing them to difficult posts in Sumatra, Celebes, or Bali, before calling them to the relative repose of Java. 
One of the characteristics of the various capital and other towns of these Residencies is the sparsity of the population, especially as compared with the over-population of Java.

The Residency of the Highlands of Padang covers a magnificent country, which is overlooked by the high peaks of Merapi and Singgalang, and whose agricultural wealth is surpassed only by the wealth of coal beneath the surface. The capital, Fort de Kock (in Malay Bukit Tinggi), stands at a height of nearly 3,000 feet. The surroundings are most beautiful, and the climate is equable and refreshing; an advantage which attracts many sufferers from beri-beri or liver complaints. The population numbers only 2,290, of whom $25^{8}$ are Europeans and 345 Chinese. The position of Fort de Kock is especially good from the strategical point of view, but the destiny of the town is to become a centre of a new civilisation. The establishment of a Normal College for native teachers, and of a rack railway which connects the town with Padang and Padang Pandjang, already witness to the double capacity which the Dutch have assigned to the little capital. Padang Pandjang ( 1,907 inhabitants, including 207 Europeans and 340 Chinese), a district capital, is the most rainy spot in the whole Archipelago. Pajakumbu, or Pajakombo, which has even fewer inhabitants, is superbly situated amid luxuriant plantations of coffee ; Solok ( 1,443 inhabitants), Fort van der Capellen (723 inhabitants), and Lubu Sikaping, are more important from a military than a political or economic point of view.

The capital of the Lowlands of Padang-Padang, with 9I,440 inhabitants, of whom I,789 are Europeans, 5, I 36 Chinese, and 2 ro Arabs-is, we must admit, a city of respectable size.

Built on the Padang River, at the confluence of the Ajer Padang Aran and the Ajer Padang Idal, and scattered among groves of coco-palms and mango-trees, with the smoking cone of Talang shouldering the horizon; a patchwork of houses, orchards, trees, and avenues, gay 


\section{SUMATRA AND RIOUW LINGGA 291}

with flower-beds in the European quarter, the city has a rustic seductive charm; but for all that it plies a very important trade in all the products of the interior : coffee, tobacco, copra, gum dammar, and rubber: and an equally important export trade, which passes through its port, Emmahaven. Priaman, Ajer Bangis, and Painan, district capitals containing from I,770 to 2,890 inhabitants, are also engaged in trade, which is facilitated, in the case of the two first-named, by the possession of a safe and well-protected harbour.

The Residency of Tapanuli has for capital Padang Sidimpuan (I7,6ro inhabitants, 84 being Europeans and 565 Chinese), a small but active commercial centre. Siboga, which has been supplanted by Padang Sidimpuan, its excellent port being insanitary, has only 3,128 inhabitants; Gunung Tuwa, Sipirok, Penjabungan, Kota Nopan, Tarutung are district capitals, perhaps with a future before them, but none of them at present has a population exceeding a thousand. Natal, thanks to its port on the river of the same name, carries on a trade with Singapore, and exports salt from the Government depôt ; its population numbers 2,879. Kota Baru was a great city under the Hindus, formerly the second trading centre on the coast, ranking next to Padang as a market for benzoin and camphor throughout the seventeenth century, but its trade was killed by the Achinese occupation in the eighteenth century, and to-day it is only a poverty-stricken village. Singhel, although once a royal city, was also brought to decay by the Achinese domination.

The Residency of Benkulen (Bencoolen) has its capital at Benkulen (7,72I inhabitants), whose past was richer than its present. The English and the Dutch in turn wished to make it a great commercial centre, and the capital of all their possessions on the Indian Ocean. But the roadstead, though safe, was silting up; the climate was unhealthy and the town stricken with fever; factors which defeated the plans of Raffles and the Dutch East Indian Company. To-day Benkulen is in decay. The 
district capitals, Mokko Mokko, a small port frequented by vessels engaged in the coasting trade, Pasar Taiis, Manna, Bintuhan on the Bay of Sambat, and Kepahiang, on the upper waters of the Musi, have none of them over r,200 inhabitants. Only Kroë, with its well-sheltered bay where the steamers of the Koninklijke Paketwaart Maatschappij call, has a population of 1,347 .

The Residency of the Lampongs is almost as sparsely populated. The activity of all its ports on the Straits ' of Sunda is limited to an insignificant coasting trade. The capital, Telok Betong, which is built on a fairly deep inlet or bay, boasts only of 3,759 inhabitants, of whom 62 are Europeans, 850 Chinese, and 93 Arabs. The trade is principally in the hands of the Chinese and the Arabs.

Tandjung Karang, Gunung Sugi, Sukadana, Kalianda, and even Kota Agung, on Emperor Bay (Keizersbaai), which is also known by the name of Semangka, are only insignificant collections of native kampongs, although they are district capitals. Menggala alone, on the Waikanan, but some distance inland, is more prosperous, boasting of nearly nine thousand inhabitants.

The Residencies of the East Coast present a very different picture, being full of movement and vitality.

The capital of the Residency, and formerly of the celebrated Sultanate of Palembang, is the city of the same name, containing 60,985 inhabitants. Among these are 572 Europeans, 7,304 Chinese, and 2,420 Arabs; a proportion that testifies to a vigorous export and import trade. The city is exquisitely picturesque, rising gradually from the two banks of the River Musi, at a distance of some 55 miles from the sea. So long is its river frontage that it takes from two to three hours to row from end to end. Palembang is accessible to vessels of heavy tonnage. Its houses are raised on piles; those of the rich Arabs, and of the Chinese especially, are built of the precious tembesu ${ }^{\mathrm{x}}$ wood, decorated with carving and gilding, or

- Tembesoe, tembesu, temusu. Fagraa fragrans Roxb. (Logoniaca). An excellent wood for building and cabinet-making, \&c. (density ${ }^{\circ} 8$ ), which the Dutch call "Palembang ironwood" (Palembangsche 
brightly painted, and, surrounded by small gardens, are to be seen in their special quarters. The centre of the great river, which is more than a thousand feet wide, is occupied by other houses-Arab, Chinese, Hindu, Malay - perched high above the water on account of the terrible freshets, and resting on large rafts, which keep their stations so long as they have anything left to sell, and then work up into the interior of the country to lay in their stock of merchandise, towing their floating houses where they will, halting where they will.

The European quarter is set apart from the native kampongs. A graceful mosque of stone, marble, and teak, with three superimposed conical roofs, and a fine octagonal minaret, overlooks this East Indian Venicegay, dirty, swarming with life, and luminous with sunlight.

Tandjung Radja, Mura Dua, and Talang Betutu are of no great importance; Sekaju is more active; Lahat, in the midst of dense forests which are still over-full of tigers, is a good military position ; Tebing Tinggi ( 1,328 inhabitants), on the Musi River and the highway from Palembang to Benkulen, has a still greater strategical value, on account of its moral effect upon the seditious populations in the neighbouring districts. Tebing Tinggi seems to be destined to acquire an importance of a very different order, as for some years past large mining concessions have been granted in the district.

Djambi (8,993 inhabitants, of whom 38 are Europeans, 530 Chinese, and 533 Arabs), which is built upon both banks of the Djambi River, was formerly almost as picturesque and flamboyant as Palembang; to-day the European quarter consists of ten or twelve houses on the right bank, opposite the kraton of the Sultan, which by their very presence annul the despotism of the latter. Djambi used to be as intolerant as Palembang in the matter of allowing the Chinese, Hindus, and even the Arabs to build their houses in the town, and possesses,

Ijzerhout). It is of a light yellow or brown colour, beautifully veined, hard, solid, close in grain, and capable of taking an excellent polish. 
like the latter city, a floating town of houseboats in its port, Muara Kompei. Despite its trade with Singapore, it is declining; only a vigorous reorganisation could give it new life.

Rengat, the ancient capital of the kingdom of Indragiri, is a dead city.

The Government of the East Coast of Sumatra has its seat at Medan (14,250 inhabitants, including 905 Europeans, 6,397 Chinese, 43 Arabs, and 3,665 Asiatic foreigners : Bengalis, Tamils, \&c.), a town created by the Dutch. On the site of an old native fortress on the Deli River, in the district of the same name, they have built up the largest centre of the Sumatran tobacco trade, the whole of the neighbouring plain being devoted to tobacco plantations; but a strong garrison reminds us that agriculture has its troubles in a seditious or rebellious country. The European quarter is clean, well laid out, airy, and planted with many beautiful shade-trees. Hidden amidst the verdure are the immense buildings of the concessionary Tobacco Company of Deli, including their warehouses and offices and a large well-appointed asylum for the native immigrants (Immigranten-Asyl) who come to work upon the tobacco plantations : also a huge hospital for the European employees and native labourers of the company. The native population lives on land belonging to the Sultan, in poor kampongs of wooden huts and houses, huddled closely together; but the magnificent new kraton of the Sultan is outside Medan. Medan has an excellent outer port-Belawan-the terminus of the Deli-Medan Railway, at the mouth of the River Deli-which carries on a steady trade with Singapore and Penang. Tandjung Pura (3,612 inhabitants, including 938 Chinese), the capital of the Sultanate of Langkat, plies an active trade in pepper, petroleum, rattan, wax, gambier, and tobacco; principally with the interior, but it is entirely in the hands of the Chinese.

Lubuk Pakam, the departmental capital of Serdang, is also half Chinese, by reason of the wealth of the able Celestial traders. Tandjung Balai $(3,790$ inhabitants, of 
whom 59 are Europeans and I,79I Chinese), the ancient capital of the kingdom of Asahan, and Tebing Tinggi, in the district of Padang and Bedagei (7,014 inhabitants) are every day gaining importance on account of their increasing commercial activity, while Bengkalis $(7,920$ inhabitants, of whom 1,462 are Chinese), the former capital of the Residency, a port advantageously situated on an island, within touch of many tobacco plantations, is declining. The Dutch at one time dreamed of making it another Singapore. Its unhealthiness resulted in its gradual decay; a decay less miserable, however, than that of Siak, which was formerly the seat of a sovereign. We must also note Saribu Dolok, the district capital of Simelungen and of the Karo country (Karolanden), but a town of no great importance.

The military government of Acheen contains more villages than towns, concerning which it is as yet by no means easy to obtain exact information.

The capital of the Government of Kota Radja, containing 3,704 inhabitants (including 290 Europeans and $\mathrm{I}, 025$ Chinese) is said, doubtless with exaggeration, to have contained 25,000 in the old days. To-day it is merely a vast barracks, with the addition of kampongsChinese, Javanese, \&c.-on a specially reserved site. The kraton of the former Sultan, a huge fortified rectangle, half a mile wide and nearly a mile in length, surrounded by a deep moat, and traversed by the Krung Daru, is occupied by the Governor, the military headquarters, and a small garrison; the rest of the troops being stationed to the south of the kraton, in the magnificent camp at Nesu. We must not forget the great mosque with metallic cupolas-the Masdjid Radja - which was built by the Dutch Government in $\mathrm{r} 88 \mathrm{I}$ to replace that destroyed during a desperate battle which was fought before the town. A steam tramway, which crosses a remarkable iron trestle-way, connects Kota Radja with its port, Oleh Leh, the journey taking an hour and a half. The tramway runs along a narrow isthmus of sand, on both sides of which are innumerable 
small lagoons. Oleh Leh, or Uleieh Leueh, which was deserted by European shipping twenty years ago, has once more begun to be of some importance since the Dutch occupation, though in a less degree than Sabang (I,ooo inhabitants) on the island of Pulu Weh. Not only is the surrounding country rich in pepper, but Sabang is the shortest route, and the necessary port of embarkation, for the traveller by sea to Europe, North America, Singapore, and the entire Far East. The Bay of Sabang, entrance to which is nearly half a mile wide, contains an anchorage nearly a mile in length and over half a mile in width, while the depth runs from 13 to 18 fathoms. It has been much improved since the flag of the Netherlands was planted there in 1877 , and is accessible to warships as well as merchant vessels. Both, in fact, are using the harbour with increasing frequency, and there seems to be a great future in store for Sabang.

The Residency of the archipelago of Riouw Lingga contains no large towns. The capital, Tandjung Priok, has a population of 4,088 .

Muntok, the capital of the Residency of Banka, is supposed to contain 25,000 inhabitants; as a matter of fact this figure is disputed.

The capital of the Assistant-Residency of Billiton, Tandjung Pandan, has only 4,900 inhabitants; 18 of these are Europeans, and I,015 Chinese.

\section{III.}

We see that the population of Sumatra is by no means in proportion to its large area, and this from various causes. War between the various peoples has been too frequent to allow of great increase; while among several of the less civilised, such as the Bataks, the birth-rate has been restricted. Then rational hygiene is to all intents absolutely unknown; while other factors are poverty, insecurity of life, and the exhaustion of women by premature marriage or by too heavy labour. All these causes, it seems, might disappear or diminish were 


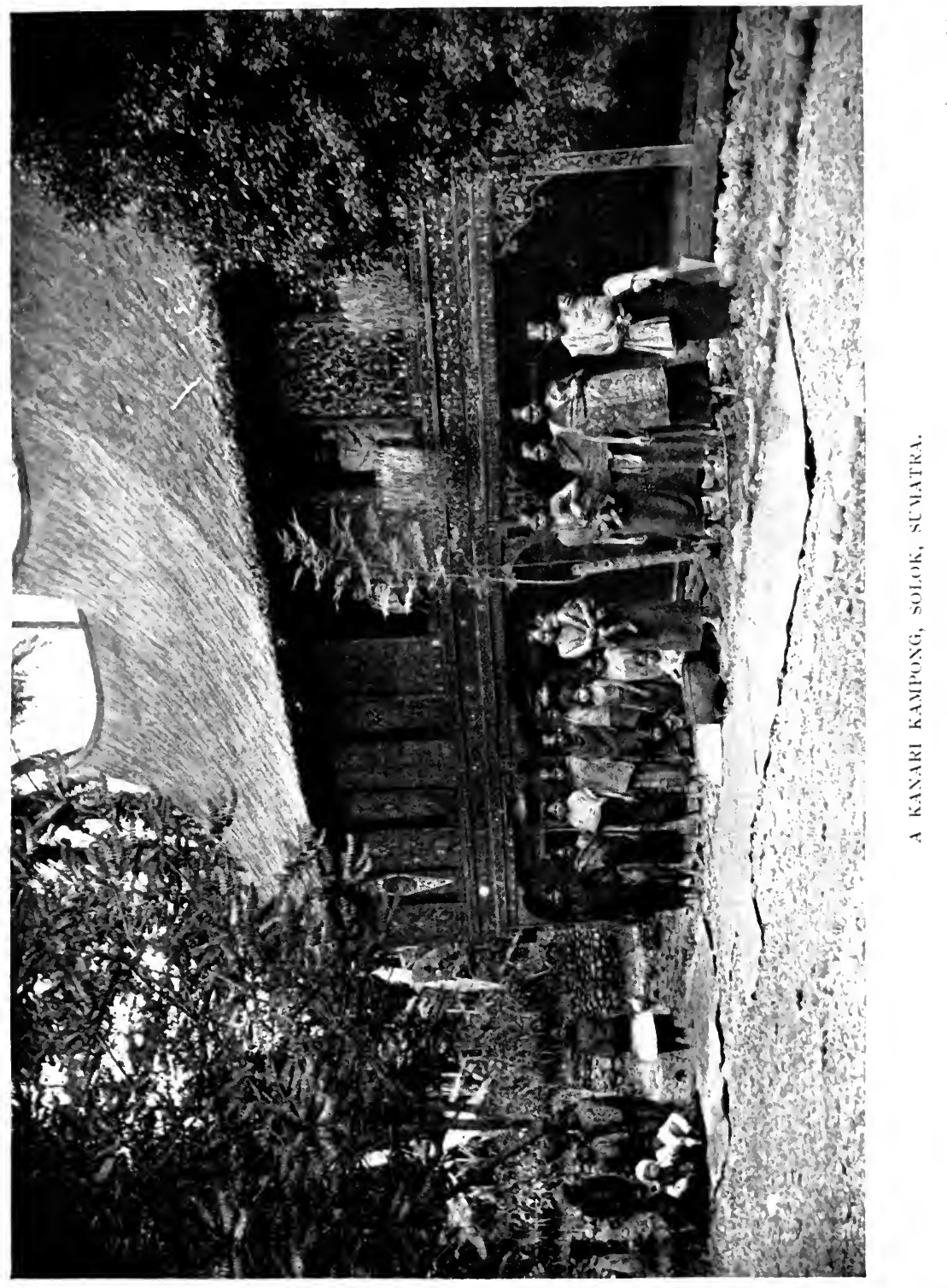





\section{SUMATRA AND RIOUW LINGGA 297}

peace and comparative wealth established throughout the island; and the first thing to be done for the benefit of the Sumatrese should be the economic development of their country; on condition that its full value should be realised without the severity and the sacrifice of human life which attended the development of Java by the system of Van den Bosch; a condition guaranteed by the humanitarian sentiment of modern Holland, and the obstinate and hostile humour of the Sumatrese.

A glance at the natural wealth of Sumatra, by which the natives benefit so little, and the remarkable results obtained everywhere when European methods and enterprise have been at work, are enough to show what the future of Sumatra should be.

This vast island, it seems, is even more richly endowed by nature than is Java. Its subsoil, to judge by a necessarily limited examination, is full of treasure : gold and silver are found in remarkable quantities in the Highlands of Padang and in the Residencies of Tapanuli and Palembang. Tin, which forms the principal wealth of Banka, Billiton, and Riouw, is also found in Siak; lead is found in the Nine Kotas and the Thirteen Kotas, to the south of the Residency of the Highlands of Padang; copper exists everywhere in the neighbourhood of the Lake of Singkarah; sulphur, naphtha, alum, and saltpetre are plentiful in the neighbourhood of all the volcanoes. Magnetite exists in the district of Tanah Datur; lignite in the Highlands of Padang, at Siboga on the Indrapura River, and at Benkulen; and marble on the upper reaches of the Indragiri. Finally-which opens a wonderful future for Sumatra as a mining country-not only is the subsoil rich in auriferous and other ores, but there are magnificent coal-measures in the Highlands of Padang at Ombilin (Umbilen, Umbilien, Dutch Oembilen), and at Behangen in Palembang, and petroleum in Palembang, Siak, Deli, and Achin.

The island is no less richly endowed with vegetable wealth. On the more thickly wooded western coast and throughout all the centre of Sumatra there are 
abundant forests ; full of teak, santal, and ebony, to say nothing of less valuable varieties of timber; and what is perhaps still better, all the gum-producing trees-the camphor-tree, the benzoin-tree, and countless others. Palms are found as in Java, in all their varieties, from the coco-nut and the areng to the sago-palm; the latter is in particular found throughout the whole archipelago of Riouw Lingga. All the eastern coast of Acheen is planted with areca-palms, and supplies part of Sumatra and even part of Java with areca-nut for the preparation of sirih.

Food crops and others grow at their best in Sumatra. Rice is found almost everywhere; coffee grows admirably on the whole of the east coast; less so in the Lampong country, and passably in Palembang. Tobacco succeeds admirably on the west coast; pepper and the nutmeg are grown to a certain extent everywhere ; but intensively in Acheen, which before the chronic warfare with Holland commenced furnished nearly two-thirds of the world's consumption of pepper, nearly 18,000 tons having been exported annually, especially from the ports on the west coast. Sugar-cane grows best in the Riouw archipelago, which is less humid than Sumatra.

The Sumatrese native has not many resources in the department of the chase. The great wild bull is rare; the boar is despised; the tapir is almost uneatable. With the exception of a few of the larger beasts, and innumerable herds of deer, whose flesh is widely eaten in the dried state, and whose tendons and hooves, and antlers, if still young and with the velvet on, are greatly sought after by the Chinese in Java, there is little edible game. Roedeer also abound, and birds of endless variety.

The fisheries should be more fruitful, for fish of almost every species swarm upon the coasts of Sumatra; being even more plentiful than off the Javanese coast. Sea fish or river fish-mackerel, tunny, rays, sharkscaught for the sake of their fins, which are sold to the Chinese-carps, barbel, eels, and in particular the delicious Indian shad or trubuk, of which the flesh, 
whether fresh or dried, and especially the prepared roe, is greatly appreciated throughout the Archipelago. There are extensive shad fisheries on both coasts of Sumatra, particularly on the eastern coast. The bulk of the product, so highly esteemed in Java, is exported from Palembang and Djambi.

In the seas around the Riouw Lingga archipelago are found agar-agar, trepang, and also the ekor bahar, a brilliantly black coral, shaped like a horn. The cliffs and caves, both in Acheen and Riouw, yield the precious nest of the sea-swallow.

\section{IV.}

What profit do the Sumatrese derive from all these natural resources? Simply their living; rarely a little comfort. They plant rice for their own needs, but always in an insufficient quantity, thanks to sheer lack of foresight and indifference to the morrow. In one detail their methods of cultivation are superior to those of the Javanese: namely, they reap the rice with a sickle in place of cutting it one stem at a time with a little knife. They eat a portion of the produce of their hunting and their fisheries, and sell the rest at absurd prices to the Chinese, who alone profit by their efforts. With the exception of gambier ${ }^{2}$ and pepper, and spices,

- Agar-agar, the Malay name of an edible seaweed, Spherococcus lichenoides. Boiled in water, it forms a jelly which is greatly appreciated in the Far East. It is used in the composition of swallows'-nest soup, and is also employed to make silk or paper transparent, being applied in the form of a clear paste.

This forms a favourite and a ceremonial dish among the South Sea Islands. In Scotland the seaweed named "dulse" is eaten both raw and cooked; and in Wessex the green laver is boiled, forming an imperfect jelly, and used as a condiment with meat, fish, \&c.-[Trans.]

- Gambir or gambier, an extract obtained by evaporating in the open air decoctions of the leaves of the Unicaria gambir Roxb., or the Nauclea gambir Hunt. The dried deposit is exported in the form of cubical cakes about one inch in diameter. Gambier is used in the preparation of quids of betel. The Riouw archipelago 
of which long contact with Europeans and the example of the latter has taught them the value-especially the Achinese-the natives of Sumatra export practically nothing except a certain amount of building timber, copra, rubber, gum dammar, and hides, principally to Singapore or Batavia ; very seldom as far as Amsterdam. The principal trade of the island is from one side to the other, from one port to the next, sometimes by the primitive method of exchange. As the commerce of the island is principally in the hands of the Chinese, though there are a few rare Europeans who are by no means their inferiors in rapacity and duplicity, the profit which the irresponsible native derives from it is practically non-existent.

The industries of Sumatra are strictly local and regrettably primitive. The island produces nothing that is really worth mentioning beyond some basketwork, filigree-work, a little notably good work in copper, and a few textile products woven in the Highlands of Padang, in Palembang and in Djambi. The pottery, rattan furniture, clothing, jewels, and arms manufactured in the island only testify to an ability and a civilisation of the second class.

\section{V.}

The Europeans are now demonstrating to the natives that they might extract both gold and a higher standard of living from their native soil; but hitherto the natives have hardly derived any other benefit from the process than the example itself.

The mines of Sumatra have for twenty years been exploited in a manner both rational and profitable.

The tin-mines of Banka, Billiton, Singkep, and the archipelago of Riouw, which were discovered in the

produces an enormous quantity, of which more than 7,000 tons comes from the small island of Bintang. The trade in gambier is as yet monopolised by the Chinese, who export it to all parts of the Archipelago. 
eighteenth century, probably between 1709 and I7II, and were leased by the Chinese from the Sultan of Palembang, were worked by the Chinese without much method, but greatly to their profit, until 1740 , when the Dutch seized upon them and made them a State monopoly. The Chinese, who came, in proportions roughly equal, from Amoy and Canton-the latter being much inferior both in mind and morals-from being the tenants of the mines, became miners, overseers, or coolies.

In 1907-1908 the total production of Banka tin was II 5 I 5 tons, while about 18,000 miners or coolies were employed. Billiton, with 73 mines and II,I 28 workers, produced 4000 tons; excluding a small amount produced by the natives. At Singkep, in the island of Riouw, I,009 workers produced 307 tons. From this tin alone the Dutch Government received a revenue of nearly $£ 2,000,000$.

This handsome addition to the East Indian budget is destined to preserve its equilibrium, and is certainly well employed, but it is none the less greatly regrettable that all this wealth contributes so little to the welfare and improvement of the natives. The natives live altogether apart from the mines, and are extremely poor; the coolies that work in the mines are drawn from the dregs of the Chinese population, and are very badly paid. The coolie's agent or labour contractor receives all the expenses of importing him, including passage money, cost of engagement, commission, and medical examination, and the value of his wages at the rate of I florin 20 (two shillings) per diem; but the coolie himself receives only a fraction less than $4 \mathrm{~d}$. per diem for food, and wages at the rate of r2s. 6d. per month. He must engage himself for at least a year : tempted by opium, driven by the physical distress that follows its discontinuance, and obliged to obtain all that he needs upon credit; clothed and fed at usurious prices by the stores run or leased by the labour agent himself; burdened with debts and with vices, he can no longer hope to escape from the mine, and only too 
often dies in abject poverty in sight of the natural treasure-house that has taken his life. Although during the last fifteen years the State has endeavoured to diminish the more revolting features of this trade in human cattle, there is still much to be done both in Banka and in the other mining districts.

The production of petroleum, which is in the hands of powerful private companies, ${ }^{x}$ is also yielding an enormous revenue.

In 1907 the petroleum concessions in Palembang yielded $72,010,000$ gallons; those on the east coast $30,605,000$ gallons, and those in Achin 54,430,000 gallons. Sumatra, together with Java and Borneo, places the Dutch West Indies among the great petroleum centres of the world. As for coal, in 1907, Behangan (Palembang) yielded only 354 tons; but the rich measures of Ombilin yielded 300,990 tons, and their yield has increased year by year for many years past. The construction of a railway in the Padang Highlands makes it possible to send the coal from the pits of Ombilin to the port of Emmahaven, whose fortune is being made by this trade in coal.

The mines of Redjang Lebong and Lebong Sulit, not far from Benkulen, are yielding both silver and gold. The first named yielded in 1903 (which was, it is true, a good year) $5^{\circ} 45^{8}$ tons, or more than 12,000 pounds of silver; the second 5 or pounds.

- The three principal companies in 1900 were: (I) The Royal Dutch Petroleum Company, founded at The Hague in 1890 , owning wells in Langkat and Tamiang, on the east coast, and also two great refineries, has reservoirs at Shanghai, Hongkong, Calcutta, Bangkok, Swatow, Madras, Bombay, Kurachi, Amoy, and Fuchu ; (2) The Mura-Emim Petroleum Company, founded at Amsterdam in 1897 ; (3) the Sumatra-Palembang Petroleum Company, founded at The Hague in 1897 . The two latter companies operate in the Residency of Palembang. Starting with less capital than the first, they have had the good fortune to discover deeper wells than those of their richer rival, which yield a greater flow of oil ; but in 1904 the Royal Dutch bought up all the concessions of the Mura-Emim Company. The petroleum is exported viâ Singapore to China, India, and Japan, and is replacing American oil. 


\section{SUMATRA AND RIOUW LINGGA 303}

In 1907 the production of gold in Sumatra was still greater than that of silver, amounting to 3,234 pounds' weight, and $£ 182,280$ in value.

\section{VI.}

Agriculture, in skilled hands, should prove to be the real gold-mine of Sumatra. In I833 the Dutch Government attempted to introduce the compulsory cultivation of coffee, the only crop which the climate seemed at that time likely to suit-in that part of the island wherein it exercised a genuine authority : namely, on the east coast, in the Residencies of Benkulan, Padang, and Tapanuli. Forced to abandon the system in the flourishing and peaceful island of Java, the Government could not expect to extend it to Sumatra, where the crops, moreover, were neither as plentiful nor as high in quality as those of Java. It is accordingly vanishing year by year before the free plantations of the natives and the estates of the European planters, and the Government is letting its land to the latter upon long leases as in Java.

In 1907, however, the Government crop in the Padang Highlands still amounted to $24, \mathrm{II} 7$ piculs (about I,4I8 tons) of coffee; in the Padang Lowlands to $6 \mathrm{I}_{5}$ piculs (about 50 tons); and in Tapanuli to 5,333 piculs (3I3 tons) as against $1,5^{87}$ tons produced in the same Residencies by free native labour, and $42 \mathrm{I}$ tons by private initiation. On the east coast of the island the natives produced $\mathrm{I}, \mathrm{I} 70$ tons and the European planters 2,226 tons.

In the neighbourhood of Bankulan, and in Palembang and the Lampong country, where the growth of coffee is tending to decrease, the natives produced 267 and the European planters 233 tons. Sumatra does not export its coffee direct, but sells it on the markets of Java.

But coffee is not enough to bring fortune to Sumatra. Pepper and nutmeg were experimented with; but after a series of trials the Government abandoned the intensive culture of these products. The plantations did not 
always succeed; or there was an over-production, and the prices fell. However, in addition to the pepper produced by Acheen and Palembang in 1907, Sumatra produced as much on the east and west coasts as in Acheen; namely, 380 tons of nutmeg and 56 tons of mace ; but most of this was produced by natives.

It is tobacco that should make the fortune of Sumatra, or at least of the large European companies in Sumatra. Tobacco has succeeded wonderfully, as regards both quality and quantity, on all the east coast plantations: in Sangkat, Deli, Serdang, Tamiang, Padang, Bedagei, Batu Baro, Asahan, and the Karo country; but now, owing to the formation of a powerful trust, all the plantations have fallen into the hands of a powerful financial group, I which employs thousands of hands-Malays, Bataks, Hindus, Chinese, and even Javanese ${ }^{2}$ emigrants from their own over-populated country, and has built for their use dormitories, a vast hospital, canteens, and steward's offices.

The production of tobacco in 1907 amounted to $23,34^{2}$ tons, slightly inferior in quantity to that of Java, but superior in quality, and representing a value of $£ 3,250,000$. In 1906 the crop was exceptionally good, representing a value of $£ 5,083,540$.

Here is a very river of gold, which the natives ought to be enabled, with the assistance of the Government, to swell by individual enterprise, and so turn aside some part of it to their own profit.

\section{VII.}

Such figures as these show us what Sumatra might become from the economic point of view, especially if the means of communication were improved; for we

$\therefore$ Hindus and Chinese are not allowed to rent or buy land in this part of Sumatra.

2 The Javanese are not greatly valued as agricultural labourers in Sumatra ; the climate does not suit them, nor do they grow accustomed to it. They are easy to handle, but are not strong. 


\section{SUMATRA AND RIOUW LINGGA 305}

must admit that at present they leave much to be desired. Along the seaboard belt roads are bad and infrequent, although the Government is doing its best, by means of such compulsory labour as is available, to open up as many as possible and to maintain those that already exist. In the interior there are practically no means of transport whatever, excepting almost impracticable paths or trails which the inhabitants, who as yet are far from submission, insist upon leaving as they are, with sullen and perhaps instinctive obstinacy. In case of rebellion they can take refuge in the impenetrable jungle, and defy, at least for a time, the advance of the Dutch troops.

We should seek in vain through Sumatra for the fellow to the wonderful road from Anjer to Panarukan which even to-day astonishes the visitor to Java; the iron hand of Daendels and the docile spirit of the Javanese have been equally unknown in Sumatra. The Dutch Government, than which no one is more conscious of the strategical and political necessity of good roads, is slowly but surely supplying them, with a continuity and a determination that are necessary in dealing with the populations of Sumatra. Within fifteen years from now, thanks to the State, and to private enterprise, the seaboard regions at least will be well provided with roads.

In the meantime there are already 187 miles of railway in Sumatra, belonging partly to the State and partly to private companies, and more are about to be built. To these 187 miles, of which the line to Deli takes 50 and the lines on the west coast 137 , we must add 98 miles of steam tramways, by means of which Belawan, Medan, Deli, and Tuwa are connected with a branch running from Medan to Timbang-Langkat and Salesseh, and 250 miles which runs along the east coast and through the centre of Acheen. The lines from Deli are intended especially for commercial purposes, and serve the great tobacco plantations; the Acheen line is more of a strategical value. Convinced that Acheen would never be subjected until columns of troops could be carried swiftly from one end of the kingdom to the other, the 
Government has built a line connecting the principal towns : Tandjung, Kala, Idi, Lha Seumawei, Samalanga, Sigli, Kota Radja, and Oleh-Leh. It has thus succeeded in pacifying the entire coast, and when once the interior of the country is made accessible by good roads the Achinese resistance will be vanquished.

The west coast of Sumatra is partly served by a rack railway, which is at once of commercial and strategical value; it starts from Pajakombo, passes through Fort de Kock, the key of the Bataks' country and the ancient kingdom of Menangkabau, and at Padang Padjang throws off a branch line towards the Singkarah region, which serves the mines of Ombilin, and carries not only minerals, but the coffee crops of the whole Padang region, to Padang itself and to Emmahaven. The trade of the interior of the country is carried on by means of the rivers, principally by the native praus, the magnificent streams of Sumatra being too badly impeded by alluvial deposits to allow steamers or vessels of high tonnage upon more than a very small part of their length. The exportation of the goods collected by the prau traffic is carried on chiefly by means of small coasting vessels, or by the Koninklijkc Paketvaart Maatschappij, which touches at Kroë and at Sabang every fortnight; thus connecting Sumatra with the Archipelago and the outer world. A line of English steamers also carries on an active export and import trade with Singapore, this trade being especially brisk in the case of Eastern Sumatra.

So soon as there is a complete political understanding between Holland and the peoples of Sumatra, and the latter at last consent to exploit the riches of their island ; so soon as good highways or further railways make transport and travelling an easy matter, Sumatra will be able to rival Java in wealth; and its population will rapidly increase tenfold. 


\section{CHAPTER XV}

\section{BORNEO}

I. Dimensions of Borneo : how divided among the Powers.-II. Orography and hydrography.-III. Climate, flora, and fauna.IV. The inhabitants : their manners and their civilisation.V. The establishment of Dutch supremacy in Borneo.-VI. Administrative divisions and principal towns.-VII. The economic situation; what it may one day become.

I.

BORNEO, situated to the north of Java, between Celebes, the Malay Peninsula, and the archipelago of Riouw Lingga, washed by the China Sea, the Java Sea, the Sea of Celebes and the Sea of Sulu, is the largest of all the islands which go to make up the Dutch East Indies. Its area is 285,220 square miles, or seven or eight times that of Java, and half as large again as France. Its population, however, is even smaller than that of Sumatra, being only $1,700,000$ or thereabouts (according to the most plausible estimates). Only a portion of the island belongs to Holland, and it is still the least known, the least submissive, one of the least civilised, and perhaps the least profitable, because the least exploited, of all the Dutch colonial possessions.

Very different in outline from Java, with its long and narrow shape, and Sumatra, with its gracefully curving coast-lines, or Celebes, so fantastically formed of promontories and winding inlets, Borneo gives the impression of a vast, squat island, covered with dense forests, seamed by great rivers, defended by a muddy 
littoral, backed by swamps, the home of pernicious vapours and putrid miasmata.

The Spaniards were the first to land, in I52I. The Dutch followed in 1598 ; perhaps considerably earlier. They in turn were followed by the English, who, when the Spaniards had been driven off, disputed their foothold with the Dutch East Indies Company. The conflict endured through the seventeenth and eighteenth centuries, without any notable profit on either side, for the stubborn savagery of the uncivilised inhabitants, the treacherous hypocrisy of their innumerable princes, and the suspicious hostility of the Chinese rendered their factories more precarious than profitable.

In 1892 the two rivals agreed to terms which definitely limit the province of either. All the north, and part of the west, or about one-third of the island, was abandoned by Holland, and so passed under the real or surreptitious suzerainty of England. The Sultanate of Brunei, formerly a useful ally of the Dutch, is still extant, but is reduced to an insignificant fraction of its former dimensions, while the Sultan's authority is practically illusory; it is under the English protectorate, and sandwiched between the two heirs to its past splendour. To the east are the territories of the British North Borneo Company, which in the first place were ceded by Brunei to certain Americans, but were then sold by the latter to the English company. To the west is the Rajahlik of Sarawak, which was created by a Sultan of Brunei in $184 \mathrm{I}$ for the celebrated James Brooke, and is still governed by a member of his family under the wholly nominal suzerainty of Brunei. All this part of Borneo-fertile, well watered, with a rich subsoil-has undoubtedly profited by English rule; it has been methodically explored, as much for scientific as for economic reasons; the population has increased, and towns have sprung up. Although England has not succeeded, as she had hoped, in making another Singapore of the island of Labuan, she possesses in Borneo a valuable and flourishing colony. 


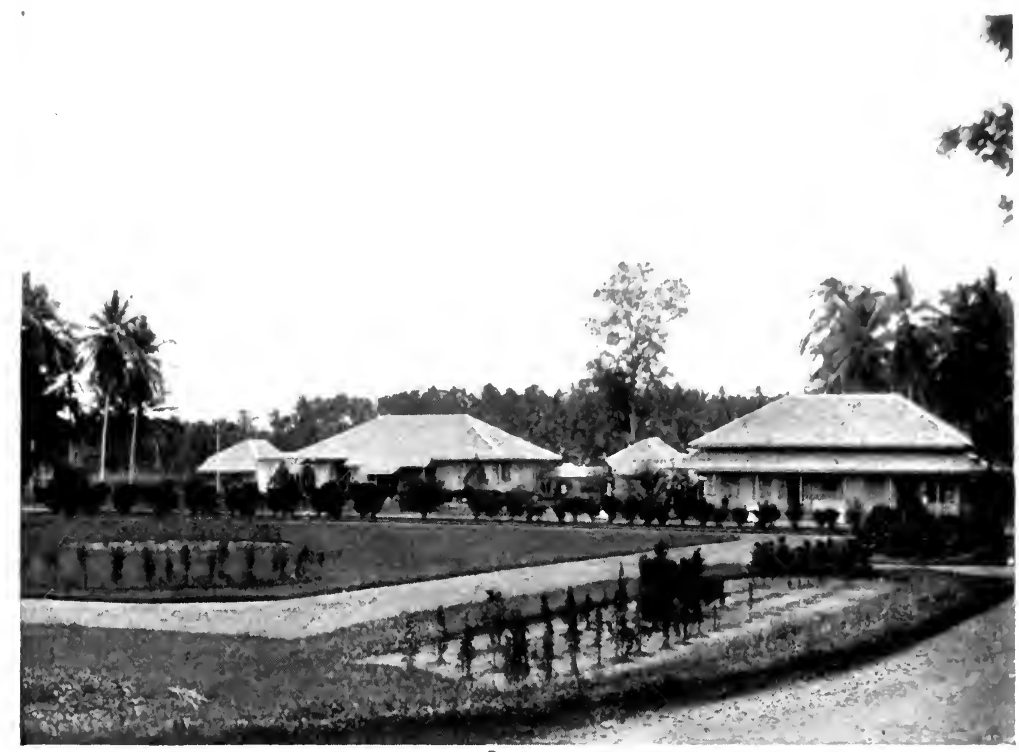

GOVERNMENT OFFICIAL'S HOME, BORNEO.

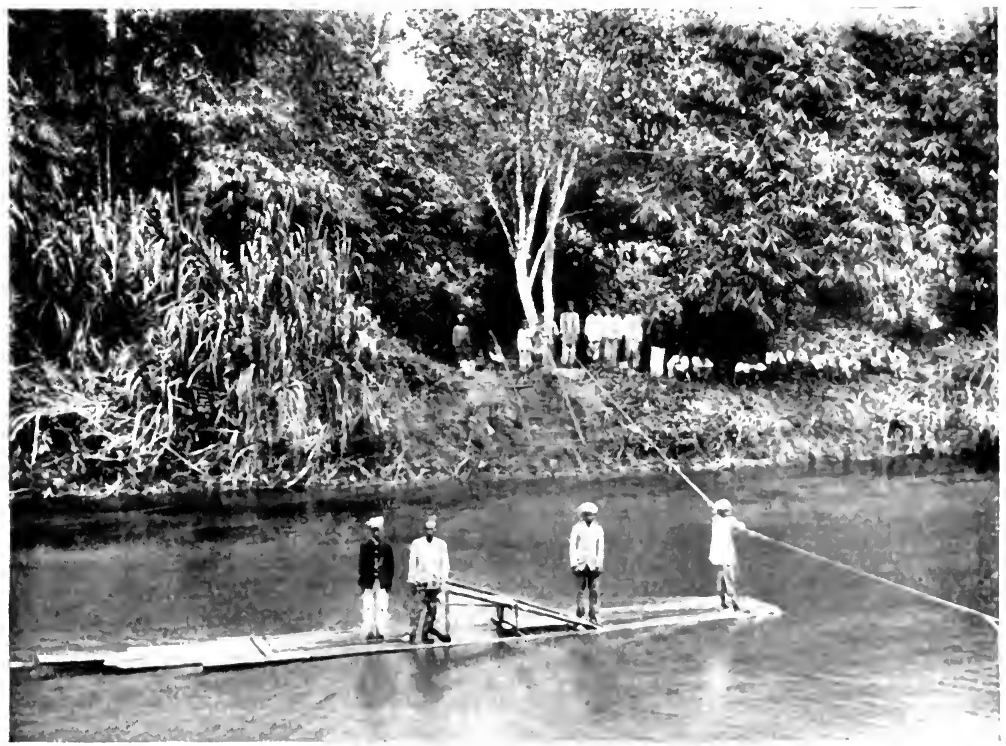

A ROFE FFRRY, BORNEO. 

Holland has retained the suzerainty of 222,850 square miles of territory : that is, of a country seventeen times as large as Holland herself, and a trifle larger than France, and a population which in 1909 was estimated by conjecture, but without exaggeration, as amounting to $\mathrm{I}, 172,800$, including $55,5^{20}$ Chinese, 3,140 Arabs, and I,382 Europeans.

II.

The geological formation of Borneo may be largely referred to the tertiary period; but in Borneo alone of all the islands of the Archipelago fossils have been found of a period anterior to the tertiary. There is much less evidence of volcanic action in Borneo than in the rest of the Archipelago.

The island is crossed by a series of mountainous tracts running from the north-east to the south-west, where they spread out into several distinct ranges. In the centre of the island also there are some ramifications of the main range, less notable than those of the southwest, which run in a south-easterly direction. The northern part of the chain contains the highest peaks of the whole Archipelago: Kinibalu, for example, on the territory of the British North Borneo Company, has been given by the latest explorers a height of 13,350 feet. Batu Tebang in the Iran Mountains is 9,80o feet high ; but the crests of the Müller and Schwaner ranges, which slope towards the south, are only some 4,900 to 5,300 feet above sea-level. Satui, near Bandjermasin, at the southern extremity of the island, is only some 4,200 feet in height.

The rivers of Borneo are numerous, with an abundant flow, and many are navigable for many miles inland; yet the majority are impeded by mud-banks, trees, and a dense alluvial ooze, which they carry seaward and deposit at the mouth, thus pushing the coast-line further out to sea, but making it pestiferous with fetid and poisonous swamps. 
The chief rivers of the west coast are the Brunei, flowing through British Borneo, on the estuary of which is the capital of the same name, and the Redjang, and on Dutch territory the Kapuas, which is considerably longer than the others, flowing into the sea through a muddy delta some 70 miles in width.

The rivers of the east coast, especially those draining Dutch territory, are of still greater importance; they are the Serojan, the Mentaja Sampit, the Katingan and the vast Barito, which is navigable far up its course by vessels of considerable tonnage. At the mouth of the Barito is Bandjersmasin, the great port of Eastern Borneo. At a distance of 60 miles above the sea the Barito divides into two branches, both of which are navigable, and one of which receives the waters of another large river, the Kapuas. The result of such a mingling of mud and water is a variable, shifting delta, whose area is seldom less than 770 square miles, and which, in times of flood, when the Kapuas and the Barito overflow, will sometimes cover an area of nearly II,000 square miles. Further to the east is the Mahakkam, or Kubi, which flows between low hills, and is as muddy as the Barito, and ends in a delta as huge and as marshy as that of the Barito.

In a country so heavily watered and so rich in valleys there are many lakes, though these cannot be compared in size or in depth with the Sea of Toba or the Sea of Singkarah in Sumatra. The more important of these lakes empty themselves into the western Kapuas, the Serojan, and the Kutei.

\section{III.}

The climate of Borneo, which is situated on the Equator, is naturally extremely hot, but quite supportable owing to its insular situ on and the sea-breeze, which cools the whole islan. As a rule the temperature varies between $72^{\circ}$ and $93^{\circ}$, although it sometimes rises higher. It is the terrible humidity of the atmosphere 
that makes the climate dangerous and so inferior to that of Java or Sumatra; a humidity due to the enormous rainfall (the average annual rainfall amounts to 78.75 inches), the abundant rivers, the dense forests, and the innumerable swamps, the source of pestilence and fever. The climate is far harder to support and far more pernicious in the interior than on the coasts, as the seabreeze falls flat amid the impenetrable woods, where the exuberant soil is always thick with masses of decomposing vegetation. The flora of Borneo is extremely rich in forest trees, the forests covering almost the whole interior save for a few jungles. Here are found all kinds of building timber, and trees of all the varieties that produce gums and resins; so that if sufficient labour and a sufficiency of good roads were available the exploitation of the forests would not merely tend to improve the health of the island, but would enrich it incalculably. Although the flora of the island, which recalls that of India, Sumatra, and Australia, accordingly as one travels to the west, the south, or the south-east, is less prodigal than that of the first two countries, and more vigorous than that of the last, it also has its own characteristics. One tree that is particularly characteristic of Borneo, by its abundance and its beauty, is the sago-palm (Metroxylon laeve Mart., M. sagas Roxb., $M$. Rumphii Wild.), which grows not only in the interior, near the rivers, but also by itself, in dense belts along the muddy shores of the great island. The pith of the sago-palm extracted and pressed into cakes will, with a few days' labour, furnish over 650 lbs. of an excellent food: in other words, sufficient to nourish a man for a year. Although there is little progress in Borneo, there is evidently no possibility of dying of hunger: nature, by furnishing man's necessities at the cost of the slightest effort, has discouraged him, so to speak, from desiring anything more.

The fauna of Borneo resembles that of Sumatra, except that the tiger is rare or absent; the elephant and the rhinoceros are encountered principally in the north-east 
of the island; panthers abound, and are extensively hunted, their skins forming part of the accoutrement of the Dyak warriors. In Borneo, as in Java, the great wild bull, or banteng, is found; there are herds of deer, which are hunted with the spear or the bow; last, but not least, comes the orang-outang, or "man of the woods," who is thought to have originated in Borneo. Numerous crocodiles infest the shore and the mudbanks of the rivers. The inhabitants of Borneo have added practically nothing to the fauna, except by domesticating the goat, the pig, the dog, and the cat. On the west coast there is an imported race of dogs with black tongues, which are greatly esteemed as food by the Chinese.

\section{IV.}

Of the very small population of Dutch Borneo ( $\mathrm{I}, \mathrm{I} 72,680$ souls) probably rather less than a million belong to the Dyak tribes, who are the real natives of the country. These Dyaks, scattered over a vast area, and differentiated according to their locality, have often been regarded as belonging to different races; but the contrary opinion is as prevalent to-day. A matter which is less clear is whether the Dyaks are autochthonous in Borneo. Not long ago, from the testimony of Arab writers, who were fertile in curious but sometimes overmarvellous recitals, and the reports of credulous explorers, it was believed that the Dyaks had driven back into the heart of the island the original sons of the soil-those savages with a caudal appendix, whom contemporary science has failed to trace. It would be more rational to admit the continued existence in the central forests of a few handfuls of stunted and miserable savages, now disappearing, armed only with the bow and the blowpipe, black-skinned, and in every way resembling the Negritos of the Philippines. The Dyaks who have replaced them are visibly of the Malayo-Polynesian race, near relatives of the Bataks of Sumatra, and also, it would seem, of the 
Chams, Bahnars, Stiengs, Radeis, and Djareis of French Indo-China. Whether indigenous or not, they are, as regards their physical aspect, extremely well built; taller and stronger than the Malays and the Javanese, with features fairly regular, and their faces, with their clear yellowish colouring, are not displeasing, despite the flattening of the nose and the prominence of the lips. Their manner is cheerful and confident. The Dyak has the reputation of being hospitable and honest, but extremely idle, indifferent as to the truth, hasty and quarrelsome when he considers himself affronted, and passionately fond of his independence and the nomadic life. But in speaking of the Dyaks we ought to distinguish between those of the coast and those of the interior. The riverside Dyaks, who have a strong admixture of Malay and a strain of Chinese and Bugis blood, were formerly subjects of the Indo-Javanese empire, as is proved by the names of their towns and rivers, and the existence of a few inconspicuous ruins of temples, buried under masses of vegetation and the oblivion of generations. They have also had long and unbroken relations with the Chinese and Arabs. Partially Islamised, at least in name, they form a race less pure than the other Dyaks, but more civilised and more sedentary, and capable, together with a duplicity often acquired by contact with foreigners, of more intelligent and energetic application. Their masters in civilisation are the Malays, who treat them somewhat as semisavages, but often form alliances with them, recuperating their own stock from the vitality of the energetic Dyaks, and converting them to Islam.

The Dyaks of the interior, vitiated by the stifling atmosphere of the tropical forest, decimated by smallpox, cholera, dysentery, and fevers, lead a nomadic, undisciplined existence; hostile to the foreigner who would tempt them to profitable labour, and the enemies of all regular and fatiguing work; and attached, above all, to their strange and brutal customs. Although these customs vary from tribe to tribe, we may describe 
the Dyak in general as clad in a girdle or loin-cloth of beaten bark, while the woman wears a short petticoat and vest of the same material, or perhaps of cotton stuff. Both sexes wear bracelets of bamboo or rattan fibre on arms and ankles, to which the women add a collar. Both sexes almost invariably wear their long hair twisted into a chignon, while the head is covered with a handkerchief or a length of cotton knotted turban-wise about the head; or in some cases the men wear a kind of cap and the women a hat woven of rattan. Certain tribes of the interior tattoo the whole or part of the body with a variety of designs, according to the sex and the social rank of the individual. On such occasions as private or public banquets the costume is embellished with bracelets of pewter, copper, or beadwork. All have the teeth lacquered; the Olo Ngadju even insert little rivets of gold between the blackened teeth.

The Dyaks would eat little indeed if they had to exist upon their few rice-fields, and if nature did not work for them. As it is they are much more difficult to satisfy in the matter of diet than the majority of semi-civilised races, and are greatly given to large banquets, at which they conscientiously over-eat themselves, and drink an often immoderate quantity of palm-wine or toddy. Their diet consists of rice, sago, various vegetables, fruits, young shoots of bamboo or rattan, the head of the cabbage-palm, and meat and fish, fresh, salted, or dried. Salt is their favourite condiment. They chew betel and smoke tobacco.

Their houses, built of wood and elevated on piles, and often surrounded by little gardens containing sugar-cane, betel, and pimento, are neat and clean. Sometimes the whole village-as among certain semi-civilised peoples of Indo-China-consists of one immensely long house, divided into as many compartments as there are families. The village nearly always possesses a communal house, raised upon piles like the rest, very large and well built, where public deliberations take place. Large banquets are held there, and the bachelors and guests of the tribe 


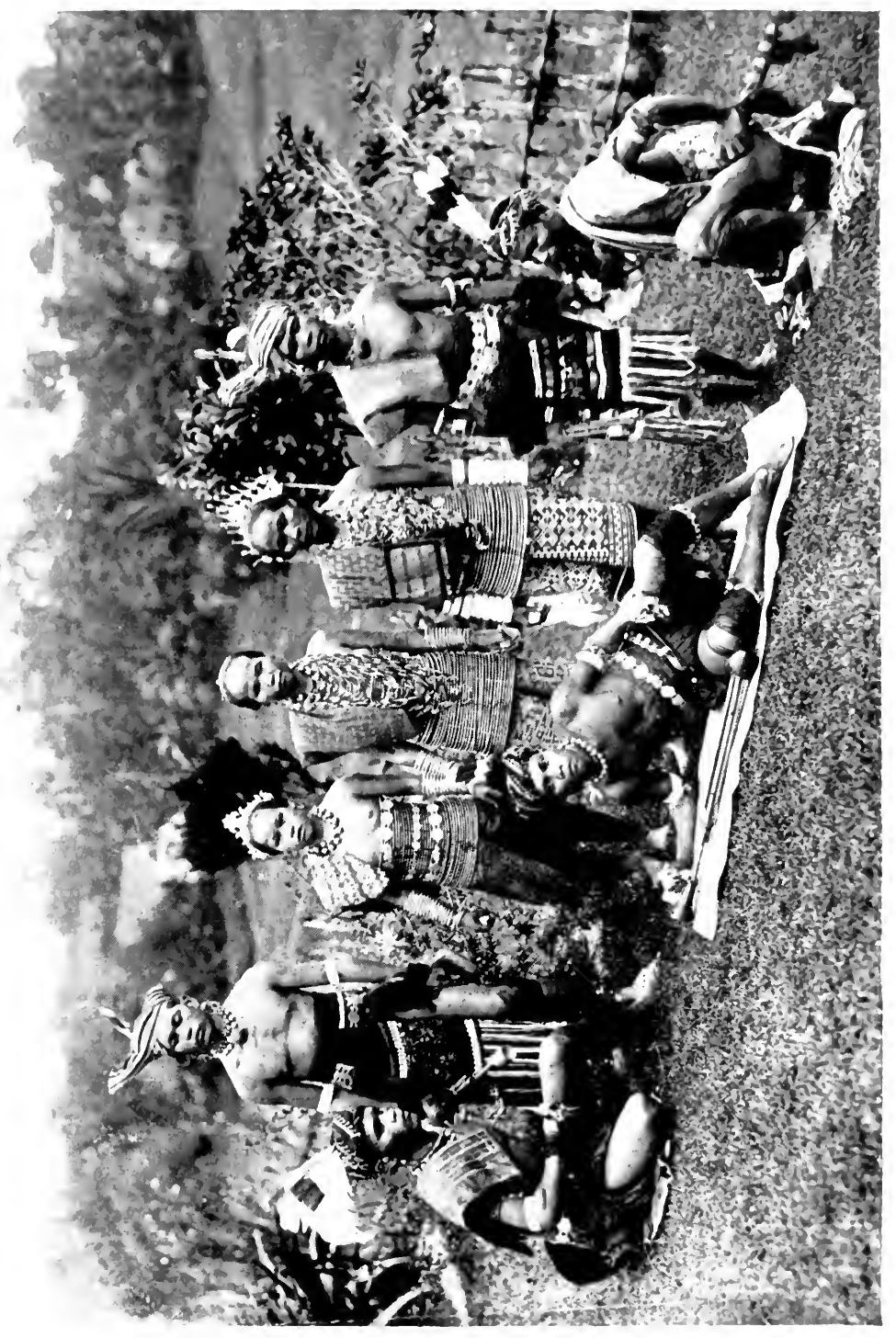

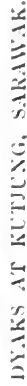



make use of it as their dormitory, as with the Bahnars of Indo-China.

The ordinary appliances of life, such as furniture, cooking utensils and agricultural implements, are very rudimentary among the Dyaks; but they are great lovers of music, dancing, tales and riddles, and, again like the Bahnars, they collect metal gongs and certain kinds of vessels which may become the homes of protecting spirits.

In the interior they are not great hunters, but in such hunting as they pursue their weapon is the spear or the bow; snares and traps are more commonly used. Their favourite game is the deer, whose flesh they dry. They are more energetic as fishermen, and their rivers are plentifully stocked, while on the coast the celebrated trubuk is often encountered in shoals. The Dyaks cultivate a little rice and a few sweet potatoes in a very primitive manner, and without much enthusiasm; but they feed principally on the products of the forest.

Marriage among the Dyaks is sometimes exogamic, sometimes endogamic; but although the Dyak woman is the object of extreme respect in the tribe and in her home, the husband alone is the head of the community; though when he dies the wife may succeed him, inheriting his duties and his dignity. Marriages are conducted by means of go-betweens, and the prospective husband must first give his future parents-in-law a present, even if the latter are opposed to the marriage.

The young people of the tribe are free, from puberty onwards, to make their own choice; but in practice they nearly always allow themselves to be guided by their parents.

The birth of twins, as with many peoples of the Far East, is regarded as unlucky.

The Dyaks, who are neither Mahomedans nor Christians, practise circumcision and a kind of baptism, without any idea of religion attaching to either ceremony. They sometimes expose their dead in trees, and sometimes burn them. Certain tribes of the Upper Kapuas 
bury them, and collect the bones in the family tomb after the flesh has disappeared. $x$ Others hollow out part of the trunk of a growing tree, and insert the corpse in the hollow. The bark is carefully replaced over the opening, and the tree continues to grow and flourish, a living tomb, in the literal sense.

The language of the Dyaks is closely related to the other Malayo-Polynesian dialects. They have no alphabet, no writing, but their psychical concepts are fairly definite. The Dyaks of the north are animists; for them everything is haunted by a spirit, a soul, which has the power of leaving the living or inanimate object (if we may use the word inanimate in this connection), which serves it as envelope. It is this straying of the soul which in man causes sickness; or death, if the fugitive will not consent to return.

The Dyaks believe in a supreme, creative god, whose name varies with the different tribes; but they think far less of him than of the evil spirits which people all space : spirits divided into categories according to their habitat, and to whom all moral and physical ills are attributed: such as epidemics, death, and the failure of crops. Priest-sorcerers (the part may be filled by a woman), balians or basirs, propitiate them by sacrifice, and by prayers in a special language known as basa sang yang, "the tongue of the spirits," which is also employed in incantations.

The Dyaks of the south are shamanists, and equally superstitious. The sorcerer is the chief regulator of their lives, and often their plague, as is the bojau among the Bahnars.

The Dyaks have earned their regrettable celebrity by their barbarous custom of head-hunting. It is now, thanks to the efforts of both Dutch and English, abandoned in the river districts, but is still extant in all its vigour in the central forests.

No Dyak can become a chief (among the tribes who still honour the custom), and no man may take a wife,

- The Chams have a similar custom. 
unless he first bring to the village notables one or more heads, collected from some neighbouring tribe after a dangerous expedition, which may last for several days. A father, to win a favourable destiny for a child about to be born, will offer the mother the present of a freshly severed head. On occasions of especial importance the whole tribe, having submitted to the essentially religious ordeals of fasting and abstinence, and having undergone purification and joined in funeral dances, departs in quest of its horrible prize.

This custom, on account of which the Dyaks were formerly accused of cannibalism, is of a definitely ritualistic character; its aim is to obtain the soul of the dead man as the protector of the killer and of his village. For this reason the heads, being thoroughly dried, cleaned, and ornamented with flowers, are the object of a regular cult. The Dyaks never forget, when feasting, to offer them the tit-bits of every dish, and the customary quids of betel-nut, in order to induce them, by such kind attentions, to adopt their new tribe.

\section{V.}

It will be imagined that the presence of such a race made the establishment of the Dutch in Borneo a somewhat unprofitable and far from easy matter, and this for many generations.

As early as 1609 the Company of the East Indies had successfully entered into relations with the kingdom of Sambas; later on, with the kingdoms of Mampawa, Sukadana, and Bandjermasin. The factories established yielded such trifling returns that Daendels had them abandoned in 1809 in order to concentrate the entire forces of Holland upon the remainder of her spacious empire, and especially upon Java. Colonisation was resumed only in 1816 , when the Government had to contend with not only the aims of the English, but with the open hostility of the Chinese who had settled on the east coast of Borneo near the rich mines of Landak 
and Montrado, and had organised themselves into confraternities or kongsis (tongs).

These Chinese kongsis waged a war of defence from I853 to 1856 . Their defeat gave the Dutch the territory of Montrado; in 1864, having reduced or won over by pecuniary advantages the little Principalities of Western Borneo, the Dutch had no longer anything to fear upon the coast but the depredations of the Dyaks of the interior.

The conquest of the south-east commenced with the cession of the Sultanate of Bandjermasin by a series of treaties ( $18 \mathrm{I} 7, \mathrm{I} 823, \mathrm{I} 826)$; but it was a long and difficult affair; more so than the conquest of the west coast, owing to the warlike temper of the peoples of Kotaringin and Kutei. In 1844 the province was constituted, although it was impossible to guarantee it against the incursions of unsubjected Dyaks, the intrigues of the Chinese, and the piracies of the Bugis and, above all, of the Suluans. In 1859 a terrible revolt broke out at the mines of Orange-Nassau, then but recently opened; it was subdued only in 1866 ; and further outbreaks were followed by two punitive expeditions, in 1870 and 1873 . Since then the peace of Borneo has been troubled but little or not at all.

VI.

The Dutch portion of the island is divided into two Residencies : that of the west and that of the south and east.

The Residency of the west of Borneo has for capital the town of Pontianak $(20,989$ inhabitants, of whom 223 are Europeans, 7,085 Chinese, and 212 Arabs), situated on the northern branch of the Kapuas, whose wide waters glide silently between two lines of virgin foliage. Pontianak, built upon mud-banks, is a true lacustrean city ; its canals and its little bridges uniting mud-banks and houses remind one of Venice or of Holland rather than the Indies. All the houses, including those of the 
European quarter, are built upon piles; the palace of the Governor himself is founded on arches of masonry, through which the river flows. The houses of the natives are of wood, roofed with atap or corrugated iron, and are grouped together in kampongs. They have a poverty-stricken appearance beside the Chinese quarter, which is even more remarkable for its neatness and cleanliness than for its activity. Its tokos are sheltered by long verandahs, which, supported by posts of ironwood, line the footpaths and streets. The Chinese kampong is the centre of all the important business affairs of the town. It is overlooked by a pretty mosque with three superimposed roofs, which stands on a little island close at hand. The Malay village is busy and animated, but less well kept. The palace of the Sultan, at the edge of a little bay, is a large building of one story, surrounded by a high palisade of ironwood, which is backed by a wall of stone. The name alone is palatial. The members of the prince's family and the high dignitaries of the court live either within the walls of the palace enclosure, or beside the kraton. Enthusiasts declare that the climate of Pontianak is healthy, and quite endurable; the lack of drinking-water is the one serious drawback.

Pontianak is assured of an enviable economic future by the neighbourhood of valuable mines, rather than by the meagre industries of the Dyaks or those of the natives of a different race. Sambas ( 12,096 inhabitants), the capital of the ancient kingdom of the same name, is still prospering, thanks to the exploitation of the neighbouring gold-mines. The other district capitals are Sanggan, Katapang, Nyabang, Kualakakap, and Sintang ; mushroom towns of from three hundred to three thousand inhabitants. Mampawa (3,389 inhabitants, of whom 1,360 are Chinese), on the other hand, is a progressive town with a future before it ; not because it contains, in a socalled palace of clay, a Panenbahan, the relic of bygone tyrannies, but because it is the outlet of a rich agricultural region. Tajan ( $1,45^{2}$ inhabitants), situated on the River 
Kapuas at some distance above Pontianak, is another town to profit by the proximity of mineral wealth.

The Residency of the south and east of Borneo (Zuider-en-Oostorafdeeling van Borneo) has its capital at Bandjermasin ${ }^{\mathrm{I}}$ (16,708 inhabitants, of whom 453 are Europeans, 2,58I Chinese, and 910 Arabs), on the beautiful Barito River. Like Pontianak, it has all the peculiarities and all the charm of a water-city. Built at the confluence lof the Barito and the Martapura, on the little marshy islet of Titas, its houses, raised on piles, are twice a day isolated by the tides; the people go about in praus, which thread the muddy canals, crossed by little ironwood bridges, which serve as streets. Bandjermasin, thanks to its fortunate situation, is the centre for all the products of the fluvial basin of the Barito : gold-dust, coal, wax, rattan, various gums and resins, copra, pepper, dried meat, timber for house- and ship-building, baskets, mats, and the sea-swallows' nests which are so plentiful in the caves of the coast, and which the Chinese buy so eagerly.

Of the district capitals Matapura (9,298 inhabitants) was formerly the residence of the Sultans of Bandjermasin; Kadangan (4,070), Muaratewei, Marabahan, and Sampit are towns of little more, and sometimes less than three thousand inhabitants. Tanah Grogot, Kualakapues, and Kota-Baru are even smaller, and are all awaiting the development of the subsoil. Amuntai, thanks to its proximity to the gold- and diamond-mines of Nagaru, is already a growing town.

Samarinda, in the east of the Residency, is still more prosperous, although it contains only 4,730 inhabitants, of whom I,I60 are Chinese. It is built on the delta of the Mahakkam, or Kutei, which is there over I,000 yards in width ; it contains a European quarter, a palace, and a shadowy Sultan, and Chinese, Malay, Bugi, Dyak, and Bandjarese kampongs. The Bandjarese, or natives of

I Some authors profess that Bandjermasin contains fifty thousand inhabitants, of whom nearly forty-five thousand are natives; that is, Dyaks, Malays, Bugis, \&c. The others are the official figures. 
Bandjermasin, have outrivalled even the Chinese in the exportation of rubber and rattan. A dirty town of small, squat-houses with atap roofs, perched upon piles as usual, Samarinda expects, none the less, to become a a considerable city, as the coal-mines and petroleumfields in the neighbouring district are now in process of development.

\section{VII.}

Borneo has all the gifts needful to make it one of the fairest and richest countries of the globe. Its soil rivals that of Java and Sumatra in fertility; crops of all kinds yield abundantly, as may be seen in British Borneo, where, thanks to the existence of sufficient labour, the soil is covered with rich plantations.

In Dutch Borneo, vast as the country is, there is a serious deficiency of labour. Head-hunting, a birth-rate unduly low, and an enormous death-rate, due to smallpox, dysentery, cholera, and fevers, leave the population of idle Dyaks unchanged; eight-tenths of the soil is virgin; a little tobacco and pepper is grown, but the agricultural yield of the country is practically limited to building timber, rubber, a little copra, and a few gums, waxes, and resins brought down from the interior by the praus that trade up and down the rivers. There are practically no industries; the Malays of the west have to obtain from Java or Singapore the raw material for the stuffs they weave.

The subsoil is even richer than the soil; neither Java nor Sumatra can compare with Borneo in the matter of mineral wealth. In the basins of the Kapuas, the Martapura, and the Kutei, and in some of the islands off the coast, gold, silver, lead, copper, antimony, zinc, bismuth, platinum, mercury, arsenic, coal, and petroleum are found. Diamonds are found in the Nagara district. The Sumbar district was celebrated centuries ago for the famous Montrado mines, and the sovereigns of the Far East used to dispute the possession of the diamonds found in the bed of the Martapura, on account of their 
perfect limpidity. Although the diamonds have become less plentiful and the gold is apparently giving out, there are coal-measures and oil-fields, which to our utilitarian eyes form a more solid form of wealth.

The official statistics relating to the profits of agriculture in Borneo-where its progress is almost as dilatory and elusive as the Dyaks themselves-mention only a few piculs of mace and nutmeg; but the statistics relating to the mines of Borneo are highly satisfactory.

In 1907 the European concessions on the Kutei and at Pulu Laut yielded 6,000 and 92,800 tons of coal respectively; an amount sensibly larger than in the few previous years. Native labour in the west of Borneo furnished 18,127 tons, instead of 2,823 as in the preceding year.

The petroleum obtained by the three large companies working on the Kutei, of which one is English and two Dutch (the Kutei Exploitation Company and the Dordrecht Petroleum Company), amounted in 1907 to close on II0,000,000 gallons.

About $600 \mathrm{lb}$. of gold, 6,600 lb. of silver, and 700 carats of diamonds were produced in the same year.

Transport is facilitated by the fine rivers of Borneo. The Royal Mail Steamship Company unites Borneo to the rest of the Archipelago and the outer world. A good road runs along the coast from Bandjermasin to Samarinda on the one side and to Sambas on the other. When Holland, having at last completed her work of pacification in Sumatra, is able to concentrate all her efforts upon Borneo, and succeeds in transforming the Dyaks into a more civilised and settled population, and perhaps in transplanting the surplus population of Java, the island will become a most valuable possession, and wealthy among all the islands of the Indies. 


\section{CHAPTER XVI}

\section{CELEBES AND ITS DEPENDENCIES}

I. The situation and aspect of Celebes.-II. The physical geography of the island; its climate, fauna, and flora.-III. The inhabitants : Bugis, Macassars, Alfours, Toradjas.-IV. The establishment of the Dutch in Celebes. $-V$. Administrative divisions : I. Residency of Celebes and dependencies; 2. Residency of Menado.-VI. The economic outlook and the future of Celebes.

\section{I.}

Celebes, $\mathbf{x}$ situated to the south-east of Borneo and separated therefrom by the Strait of Macassar, is washed on the north by the Sea of Celebes, which divides it from the Philippines; on the south by the Sea of Banda and the Sea of Flores, dividing it from the groups of islands of the same name. In size it is the third largest island of the Archipelago. Its area is roughly 76,360 miles,

3 The old Portuguese navigators thought Celebes (Selebes) a group of islands - a natural mistake, if we consider how the periphery is cut up into numerous great promontories by deep, tortuous gulfs, which have all the appearance of straits-and so gave the name the plural form. We find, however, both singular and plural forms-Celebe and Celebes-in old narratives. Several explanations of this name have been proposed; for it is unknown to the natives. Si Lubeh or Si Labih would mean "the island up above" and might be derived from instructions as to the position of the island given by the Malays and mistaken for a name: such mistakes are frequent in geography. According to Skeat (Hobson Fobson, s.v. Celebes), the true form of the word would be Pulau (island) Salebih-in some dialects Su-lebis or Si-Lebis, Si being there equivalent to a sort of article ; and Lebih, Lebis might be the name of a man. The Malays call Celebes Tanah Bugis, "the land of the Bugis." 
including its dependencies : that is, it is rather more than one-third as large as France, and larger than Java, though smaller than Sumatra. Its population, however, amounts to $85 \mathrm{I}, 905$ only; a very small figure compared with the $30,000,000$ of Java.

Celebes would seem to have been created by nature in a capricious moment, such a medley of bold promontories, jutting peninsulas, curving bays, and deep gulfs does its outline present. It has been compared with the hand of a gouty patient, a scorpion, a crocodile, and, more modestly, with a shrimp; in any case its coastal development is abnormal in comparison with its area, for it equals the coasts of Spain and France combined; while the northern peninsula is attached to the southern by an isthmus barely 18 miles in width. The whole island, some 470 miles in length, has an average width of only some 36 to r 20 miles.

Celebes, in short, is composed of four peninsulas, connected by means of narrow tracts of land and divided by the Bay of Boni on the south, the Bay of Tolo on the east, and the Bay of Tomini on the south-east.

II.

Celebes is traversed from south to north by a range of volcanic mountains; that range which connects the whole East Indian system with the system of Mindanao and the Philippines, by means of a host of scattered islets of granite, which rise from a profoundly deep sea. This long chain pushes out a subsidiary range along the peninsula dividing the Bays of Tomini and Boni. The northern portion of the island is the more mountainous, although the isolated peaks are not so high ; thus Gunung Kalabat, at the northern extremity of the range, attains a height of 6,56o feet only, while Lompo Batang in the extreme south attains a height of ro,000 feet. Although the mountains of Celebes have proved their volcanic origin by frequent earthquakes, no active volcanoes have been observed in either Celebes or Borneo. 


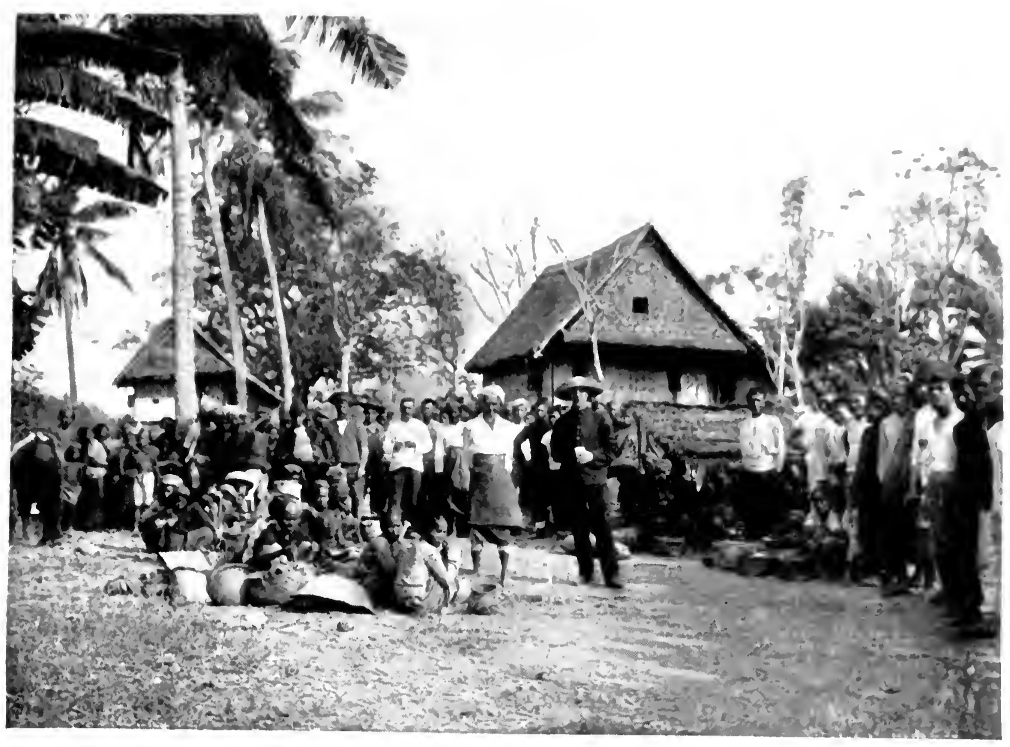

MARKET AT CELEBES.

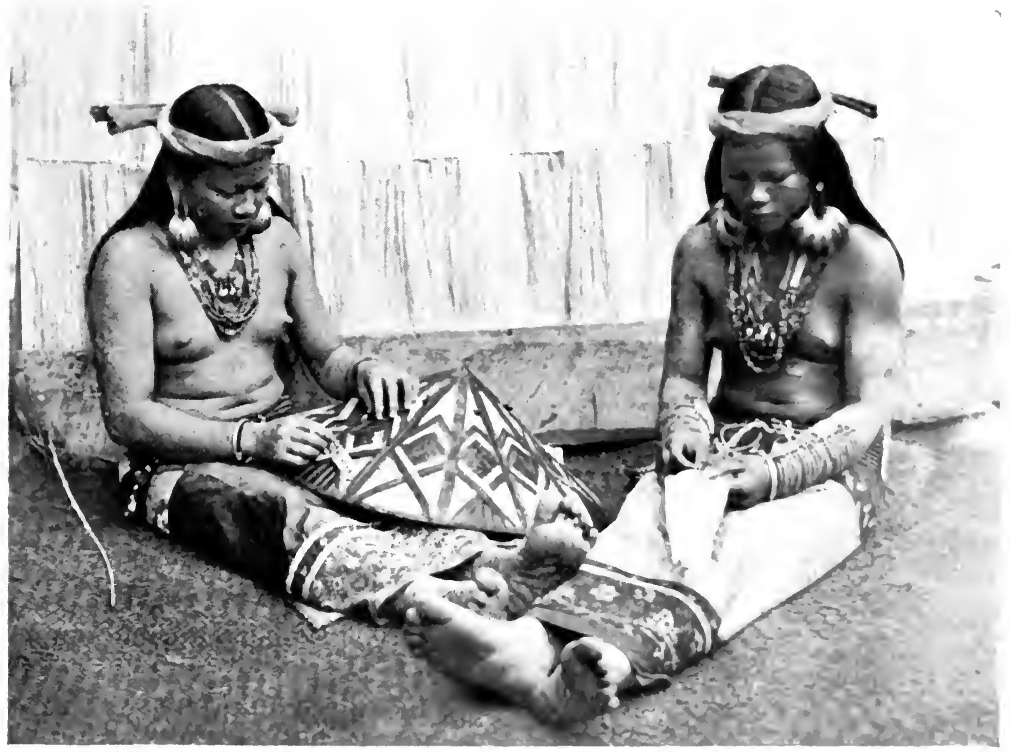



On such narrow tracts of land the rivers have scarcely room to develop; so that although they are sufficiently swollen during the rainy season, they are almost without exception extremely short. The Bahu Solo, in the peninsula between the Gulfs of Boni and Tolo, which has its source in Lake Tawuti, is nearly $15^{\circ}$ miles long; the Sadang, in the Macassar peninsula, is $25^{\circ}$ miles in length; but the Rano-i-Apo in Minehasa, the Poigar, Malibagoei, Taludaw, and the Djenemadja are all shorter. The whole island is strewn with lakes, the largest of which is Tawuti; but Lakes Tempa or Tamparang, Posso, and Lindu are not far inferior in size. All these are in the southern portion of Celebes; but there is in the northern peninsula, in the mountains of Minahasa at a height of 2,000 feet, a little lake set in a marvellous landscape and a waterfall famed through the whole Archipelago. This is Lake Tondano.

The climate of Celebes, like that of Borneo, is extremely hot, and less equable than that of Java or Sumatra. The difference between the day and the night temperature is often as much as $18^{\circ} \mathrm{Fahr}$., though the average is less. Moreover, the abundant rains, the thunderstorms, and the sea-breezes, which reach the slightest eminence in a country so completely open to the sea, render the climate of Celebes quite endurable and at some seasons even agreeable. The climate of Celebes has one great advantage over that of Borneo: the sloping surface of the island allows the rain to run off quickly into the sea, so that there are hardly anywhere such marshes as those of Borneo, which fill the atmosphere with so noxious a humidity. For this reason Celebes, in spite of its heat, has the name of being the healthiest of the Dutch East Indies.

The flora of Celebes, thanks to its maritime situation, the fertility of its volcanic soil, and its position under the Equator, is as rich and varied as any in the Indies. It is as plentiful in the plains as on the mountains; but its character, which is Indian in the western portion, tends to the Australian on the eastern slopes. Palms of all sorts, camphor-trees, cinnamon, nutmegs, cloves, tree-ferns, and 
countless varieties of the most extraordinary orchids are found intermingled. The immense forests of the interior furnish many kinds of timber. Tobacco and coffee grow excellently; in Celebes is found the Antiaris toxicaria Lesch., from which upas, a terrible poison, is drawn.

The fauna of the western portion of Celebes recalls that of Borneo and Sumatra, although the tiger and the elephant are absent. It includes the buffalo, the wild bull, the Celebes boar, which is particularly ferocious, many deer, and the last species of monkey to be found in the Archipelago. On the eastern slopes of the island commence the marsupials which abound in New Guinea and Australia. In the north is a special antelope, the anuang, or "cow of the woods" (Anoa depressicornis), I whose flesh is eaten almost daily; and among the domestic animals are some excellent little horses. There are many birds of dazzling colour-birds of paradise, parrots, \&c.-and hosts of butterflies; the latter form one of the characteristics of the island.2

\section{III.}

The inhabitants of Celebes belong to the ethnographic and linguistic Malayo-Polynesian group. Despite their close relationship to this group, they present very distinct differences among themselves, as a result of geographical and historical factors; so that the natives of the north and of the south have by certain explorers been regarded as different peoples.

The Macassars, to the number of some 230,000, occupy the western portion of the southern peninsula; the Bugis, twice as numerous, and supposed to be immigrants from the kingdom of Boni, inhabit the southern portion and the coasts of Celebes.

The name Alfours is sometimes applied to the inhabi-

- Malay, bandogo tutu, sapi utan; Bugi, anuwang.

2 The best and most recent description of the island of Celebes is that of Paul and Fritz Sarasin, Reisen in Celebes ausgeführt in den Fahren 1893-1896 und 1902-1903 (Wiesbaden, Kreidel, 1905, 2 vols.). 
tants of Minahasa in the northern part of the island, and sometimes to all the semi-civilised inhabitants, whether of Celebes or the Lesser Moluccas and the Sulu Islands. For the Mahomedan inhabitants of Celebes all "heathen pig-eaters" are Alfours. Finally, the semi-civilised mountaineers of Central Celebes are known as Toradjas; and as this mountainous region is inhabited by people of Macassar blood as well as by Bugis, the name of Toradja, like that of Alfours, responds to an intellectual rather than to an ethnographical difference.

Bugis and Macassars, despite the affinity of their languages with Malay, are physically more like the Javanese, except that they are better-looking than the latter, especially in the case of the women. They are of average height, well built, rather dark in complexion, erect and graceful. Both are excellent sailors, as is only natural in such a country: shut in by the sea on every side, and embracing the great Gulfs of Macassar, Boni, Toli, and Tomini, which themselves are again cut up into thousands of lesser bays and inlets, creeks, and natural harbours, so that the smallest kampong has the look of a port or fishing-village. Fishing, the coast trade, and even ocean commerce are their usual occupations. The Bugis especially are famous traders, as formerly they were formidable pirates ; they are expert navigators, knowing every corner of the Island seas over a range of astonishing width. They do not hesitate to make the voyage to Borneo in their praus, and have founded many colonies there on the southern and eastern coasts. They monopolise the greater part of the trade of those coasts, living in well-defended kampongs, united in a rigid solidarity. They allow no outside interference in their affairs, nor do they take kindly to the foreigner's ideal of assisting them to govern themselves. Capable of enduring great fatigue, active and laborious, and determined to preserve their individuality and their freedom, they have the reputation of being undisciplined and vindictive; angered by an insult or an injustice which they cannot directly avenge, they too readily draw the 
krees and run amok. A proud race, refusing to serve the Europeans as domestic servants, they are deplorable subordinates. The Dutch, who have often had to fight them in order to ensure their possession of Celebes, and who know of what their courage and love of independence are capable, enlist them gladly for service in the fleet, where they are, so to speak, at home among themselves, or at most the comrades of their close relatives, the Malays; but the Government has almost entirely ceased to enlist them in the army, their stubborn temperament making them almost impossible to manage.

It is only just to add that a Dutch colonist who lived for many years among them, and considered that he knew them thoroughly, declared that they were extremely loyal friends, and far less difficult to manage than has been professed. He himself, however, could not possibly pretend that the Bugis have any immoderate respect for the property of others, or that they regard pilfering and theft as other than a venial offence. In Baba and Belu the young girls marry by preference young men who are admitted adepts at this kind of "sport," and have therefore proved their dexterity of body and mind.

Formerly they were slightly tinged with Hindu influences on the coasts, but to-day they are mostly Islamites, and have accepted Islam as fervently as they resisted it for some centuries before its introduction. They are not, however, patterns of orthodoxy. In many districts they still revere the emblems of Shiva, and their ancient animism survives in the worship, possibly totemistic, which they render to the crocodile and to certain kinds of eel. The Bugis and their princes attribute a kind of supernatural power to the royal insignia, which in several Bugis Sultanates are of a fetishistic character.

They obey a host of petty princes, whose tyranny or rapacity are to some extent controlled by the pride of their subjects. The Bugis women are expert weavers, embroiderers, and seamstresses, and can often read and speak Malay, which is in general spoken fluently by the men. They have, however, like the Macassars, their own 


\section{CELEBES AND ITS DEPENDENCIES 329}

language, alphabet, and literature, which they regard with a certain pride; but their ruling passion is for cockfighting and gambling. ${ }^{x}$

The Toradjas of the mountains and the pagan and semi-savage Alfours of the centre of Celebes are mentally much inferior to the Bugis and Macassars. Wretched enough to begin with, on account of their manner of life, they reduce their race still further by the atrocious custom of "head-hunting" which with them, as with the Dyaks, is a purely ritual ceremony, being described by adat in certain determined circumstances, such as the death of a chief, \&c. The Toradjas of Lake Posso are not content with cutting the head, but also drink the blood of the victim, eating a portion of his flesh and brains. The efforts of the Dutch to suppress this custom wherever their influence extends, and the preaching of the Gospels and of Islam, the former being well received, allows us to hope that this horrible custom will not survive much longer. ${ }^{2}$

The Alfours of the Minahasa are far more highly civilised than the Toradjas, and even the Bugis. Formerly, it is true, they too were head-hunters; but to-day they are a peaceable folk, honest, and energetic, and nearly all are Christians. Fairly tall, good-looking, light-complexioned, and apparently closely related to the Polynesian-Maori race, they agree capitally with the Dutch, dress themselves and furnish their houses as far as possible like Europeans, and although they have so far found it scarcely possible to learn the Dutch language they are gradually replacing their local idiom by Malay, the official language of the Archipelago. They inhabit the most beautiful and most cheerful-looking country in Celebes.

- See B. F. Matthes, Einige Eigenthümlichkeiten in den Festen und Gewohnheiten der Makassaren und Buginesen (Leyden, I884, 8vo). Besides this and many other monographs, Matthes has published grammars, dictionaries, and anthologies of the Macassar and Bugi (Buginesen) tongues and literatures.

2 Dr. N. Adriani has made a special study of the Toradjas, and his books are the chief authority concerning them. 
In the administrative department of Celebes are included the small Sangi or Sangin Islands in the north, which lie in the route of vessels going from Celebes to the Philippines; the long island called Salejer to the south, separated from the Macassar peninsula only by a narrow strait ; and still further south, Sumbawa, which is a much larger island, entirely volcanic, geologically and ethnographically belonging not to Celebes but to Bali and Lombok. Sumbawa is remembered for the terrible eruption of Timboro (9,000 feet) in 1815 , which engulfed whole villages and ruined the island.

\section{IV.}

The Portuguese settled in Macassar in I625. In 1660 the Dutch drove them out and replaced them. For a long time they were confined to this one point ; it is only since the extension of the Dutch Colonial Empire during the nineteenth century that the whole island has been subjected to their rule. From the south-eastern peninsula they worked up the coast, making alliances with the numerous Sultans whose dominions they reached, suppressing them or winning them over according to circumstances, and always more ready to take the second course with these independent seaboard peoples. In other regions the Resident or Assistant still confines himself to collecting a determined tribute, to prohibiting any act of administration which might appear to be directed against Holland, or even against Europeans in general, and to controlling or suppressing those which seem contrary to morality or humanity. In the interior the Dutch move slowly and prudently, and the question is less one of raising taxes than of accustoming the Toradjas to the idea of the foreign master, and of a civilisation in which no one collects heads in order to influence destiny. It is a curious fact that in Celebes-the one island in which the Dutch Government must go slowly and softly in order to go forward at all-are the two cities which, more than any in the Outer Possessions, recall Holland itself, both 
in the outer aspect of the houses and their internal arrangement. These cities are Macassar and Menado: one in the north, the other in the south.

\section{V.}

Celebes and its dependencies form two distinct administrative units: $(a)$ the Government of Celebes and its dependencies, used $(b)$ the Residency of Menado.

The little kingdoms of Banggai and Tembuku, although geographically part of Celebes, are included in the Residency of Ternate.

The Government of Celebes and its dependencies, which includes all the southern portion of the island, Salejer (Saleyer), Sumbawa, and its group, has for capital Macassar (26, I45 inhabitants, of whom I,060 are Europeans, 4,672 Chinese, and I4I Arabs). The commercial suburb of Vlaardingen, overlooked by Fort Rotterdam, consists of a vast, interminable street with European warehouses and offices, Chinese tokos, and numerous godowns and stores built in the eighteenth century in the old Dutch style. This long, throbbing artery is overflowing with life and commercial activity; men surge and hasten along it like corpuscles in the blood. On the plein, or public square, are the barracks, many curious old houses, the Residency, the Club, and some fine modern European dwellings, the note of the whole being one of comfort and modern hygiene.

Near the port live the natives: Macassars, Bugis, and Malays ; each in their own kampongs, but on good terms with one another.

The port of Macassar, or Makasser, which has been a free port since 1848 , is increasing in importance daily, and is threatening Singapore with so serious a competition that the latter port has been trying to obtain a monopoly of copra in particular. Macassar, in 1902, exported 350,000 piculs. At this rate its European consignments of copra will soon exceed in quantity, and especially in value, those of all British India. If we 
compare its trade during the period $x 885-9$ to that for the period I897-I900 we find an increase of 80 per cent.

Its exports, besides copra, consist of rattan, oil of cajeput, $\mathbf{x}$ and macassar oil (extracted from the seeds of the $b a d u) .^{2}$

The carrying trade is in the hands of the Dutch, English, Germans, and Australians.

Maros ( 1,493 inhabitants), a district capital, was formerly the capital of a kingdom, now reduced to a rigid dependency; it still has a nominal Sultan. Bantaëng or Bonthain (6,889 inhabitants) owes its growing importance to its safe roadstead and to the magnificent crops produced in the neighbourhood; Sindjai (3,779 inhabitants), on the eastern coast of the Macassar peninsula, possesses similar advantages ; Takalar (I,593 inhabitants) produces first-class sailors, who are gladly enrolled in the Dutch fleet.

Pampanua and Palopo, on the east coast, which the explorers P. and F. Sarasin have described as "a little Venice in the midst of the mud," are chiefly of political significance.

Almost everywhere the Dutch Government is seeking to create new economic centres on which it keeps a tight hand, which will slowly replace the ancient "courts" of Gowa, Buton, Tanette (where a woman reigns at present), and Wadju, which are still sullenly hostile, clinging obstinately to the memories of their past importance.

The most important of these remains of states-the

- A volatile oil extracted by the distillation of the leaves of the Melaleuca cajeputi Roxb., which the Malays call the kayu putih, or white tree, on account of the white bark which covers it. The oil is liquid, volatile, green, transparent, with a strong and agreeable odour. To the Chinese and Malays it is a veritable panacea : they give it for rheumatism, gout, paralysis, epilepsy, toothache, \&c. [It is used internally in English medicine in place of eucalyptus, and is often useful in cases of gastralgia.-TRANs.]

2 Or bado in Macassar (Malay kusambi, Schleichera trijuga Willd.), a tree of the family of sapinacio. Once used by Europeans for the hair, and still so employed by the lower classes, it is the basis of various cosmetics, and is used unmixed in the East. 


\section{CELEBES AND I'TS DEPENDENCIES 333}

kingdom of Gowa, heritor of part of the ancient and well-known kingdom of Boni-has often involved the others in its intrigues; but an expedition in 1904, which performed its task in a serious and deliberate fashion, and was ably led, has to-day practically pacified all these futile revolts and the petty acts of piracy which they covered. A few decorations, diplomatically distributed, and which are at once an embarrassment and a glory to their bearers, have finally ensured tranquillity even in these nests of intrigue.

The district of Salejer, or Saleyer (54,547 inhabitants) includes the whole of the island of that name; it is not only the most populous, but one of the most laborious and prosperous districts in the whole Residency.

The Saleyerese, close relatives of the Bugis and the Macassars, are, like them, Mahomedans, and excellent sailors as well as experienced traders. They carry on a large export trade in dried and salt fish, beche de mer, copra, Macassar oil, and praus. The coco-palms, which grow in a belt round the whole circumference of the island, furnish the inhabitants with an inexhaustible source of revenue.

Bima ( $I, 569$ inhabitants) is the capital of the district including Sumbawa.

The inhabitants of Sumbawa are Mahomedans on the coast; but in the interior they practise an animism full of relics of Hinduism, as is proved by the name devas, which is applied to all their divinities. They honour these last with presents of flowers and fruits. They know nothing of human sacrifices, but after a death they burn or bury with the corpse a certain portion of the dead man's fortune, which his heirs are obliged to leave him, doubtless to assure him of a living in the next world; and if he owns any livestock their throats are cut over his grave.

Formerly Sumbawa was divided into two kingdoms, each of some importance. The capital of the western kingdom, Sumbawa, was annihilated by the explosion of Timboro. Bima, on the other hand, still exists; its ex- 
cellent harbour and its admirable ponies, which the Arabs come to buy, ensure a real future for it so soon as the timid islanders and the suspicious, petty Sultan decide to enter more openly into relations with the Dutch, who at present have scarcely penetrated beyond the town and the coast.

The Residency of Menado, in the north of Celebes, is, perhaps, more densely populated and more wealthy than that of "Celebes and its dependencies."

It comprises all the northern portion of the island, and is divided into two districts : that of the Minahasa, in the north-eastern portion of Celebes, and that of Gorontalo, together with the Sangi or Sangir Islands. The capital, Menado (10,344 inhabitants, of whom 576 are Europeans, 2,784 Chinese, and 300 Arabs), is built upon a site that is perhaps unique in the world. The town is built around a spacious and beautiful natural harbour; close at the back is a magnificent range of mountains. The European quarter consists of a few vast avenues, planted with magnificent trees, and running from the shore towards the mountains ; the houses, even the finest, are of wood and thatched with atap, so that they have not the opulent air of the stone mansions of Batavia or Surabaja, but a cheerful freshness, which is the prevailing note of the city. The climate of Menado is extremely healthy, and the heat is tempered by the sea-breeze, so that the nights are cool. Epidemics are very rare in Menado.

The climate, material comfort, and long contact with Europeans, have resulted in the cleanest and best kept native kampongs in the entire Archipelago ; but the whole of Minahasa has the aspect of a flourishing plantation. The inhabitants of Menado are content to live by the sale of their crops ; all retail commerce being in the hands of the Chinese, and the wholesale export and import trade in the hands of the Europeans. They not infrequently intermarry with the latter, the women of Minahasa, like nearly all their race, being handsome, gentle, and Christians of some standing, which facilitates these 


\section{CELEBES AND ITS DEPENDENCIES 335}

unions. These intermarriages date from a comparatively remote period, for there is a whole quarter in the town where the descendants of European merchants, who were formerly privileged by the Company, reside; although since then the majority of them have been subjected to many further crossings.

While Macassar owes its importance to its character of international produce market, Menado owes its good fortune to the fact that it is the point of export for a region admirably fertile in coffee, sugar-cane, spices, dammar, copra, and rattan. Copra seems destined to be the principal source of the wealth of these islands, which are still in the dawn of their prosperity, and almost devoid of manufactures.

In 1904 Menado exported I6,104 tons of copra, valued

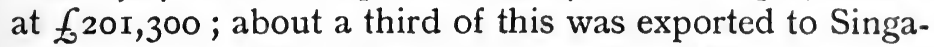
pore, and nearly another third went to Marseilles, and the rest of France took 3,892 tons; the remainder was taken by Holland, Italy, and Germany.

Menado still exports a certain amount of native gold : 1,219 lb. in 1904. In the same year the city's imports attained a value of $f_{24}, 658$, and its exports a value of $£ 446,220$.

Tondano (10,592 inhabitants, of whom 35 are Europeans and 266 Chinese), the capital of the district of the same name, is situated to the north of the beautiful Lake of Tondano, at a height of 1,960 feet above the sea. Formerly Tondano was built upon piles on the beach of the lake : but the Dutch, having had the greatest difficulty in reducing it, judged it wise to move the town inland. To-day Tondano, which is almost entirely Christian, is surrounded by magnificent coffee plantations and superb forests. It is now so completely loyal to the Dutch rule that it was judged practicable to build there the school for the sons of native chiefs (School voor zonen van Inlandsche hoofden), in which the sons of the notables and princes of Celebes and the other Outer Possessions may obtain a general and professional education suited to their future rôle. The inhabitants of Tondano are 
either agriculturists or fishermen, their lake being full of fish of all species.

Amurang (2,945 inhabitants), built in the centre of a beautiful bay on the north-west coast of Celebes, and provided with a roadstead which affords safe anchorage in all winds and weathers, is extremely picturesque of aspect amidst its clumps of coco-palms. The steamers of the Koningklijke Paketvaart Maatschappij call at Amurang, and since it has had less to fear from the incursions of pirates, which were formerly its terror, despite a fortress, now in ruins, the town has commenced to revive.

Gorontalo (6,352 inhabitants, of whom I 45 are Europeans, 666 Chinese, and 327 Arabs), situated at the entrance to the great Gulf of Tomini, and at the confluence of the Boni and Bolango Rivers, is protected by Fort Massan and a small garrison. It is the seat of an Assistant-Residency. Despite its indifferent anchorage its export trade is increasing daily, its trade being chiefly in gums, copra, dammar, rattan, wax, dye-woods, tortoise-shell, and various sea-shells. The natives are nearly all Christians, and thoroughly docile. Unhappily, the population increases but slowly, on account of the unhealthiness of the site, the town being flooded several months in the year, whence constant outbreaks of fever.

Paleleh, although a district capital, has only 3,300 inhabitants; Taruna, the capital of the Sangir Islands, has 6,090, nearly all fishermen; Donggala, at the extremity of the long and narrow bay through which the Palu River flows into the Macassar Straits, will be a town of considerable importance when the isthmus, here 18 miles in width, which connects the northern and the southern portions of Celebes at this point, is pierced by a canal running from Palu to Parigi. When this new route enables vessels to go from Macassar and Boni to Menado without sailing right round the huge island, both praus and larger vessels will flock to Donggola. 


\section{CELEBES AND ITS DEPENDENCIES 337}

\section{VI.}

Celebes has all things needful to make it one of the most fortunate countries in the Indies : an exceptionally fertile soil and a rich subsoil; an excellent climate, bays and natural harbours as equally secure and numerous, and $a$ vigorous and intelligent race.

In 1907 the Sumalatei Mine furnished nearly 3 tons of silver $\left(6,6 \mathrm{r}_{5} \mathrm{lb}\right.$.) and $\mathrm{r}, \mathrm{I} 70 \mathrm{lb}$. of gold. At Menado the coffee grown by Europeans amounted to I,4I I piculs and the coffee grown by natives ("free cultures"-that is, of their own initiative) to 3,227 piculs ( $1,680 \mathrm{cwt}$. and 3,860 cwt., or 75 tons and 172 tons), while in the rest of Celebes 29 piculs were grown by Europeans and 23,469 by natives (or $34 \mathrm{cwt}$. and 28, 180 cwt.). Moreover, this coffee, which created a considerable trade in Macassar, the port of exportation to Java, took the first rank in the East Indies in point of quality, leaving the coffees of Java and Sumatra far behind.

Menado also produced 14,242 piculs ( $17,090 \mathrm{cwt}$.) of nutmegs and 1,900 piculs $(2,280 \mathrm{cwt}$.) of mace, while the rest of Celebes produced only 5,445 piculs (6,530 cwt.) of nutmeg and $\mathrm{I}, \mathrm{I} 76$ piculs ( $\mathrm{I}, 4 \mathrm{I} 3 \mathrm{cwt}$.) of mace.

Besides these results, which the State has succeeded in recording, but covered by no statistics, is the produce of the greater part of Celebes. The smallest village in Celebes drives an active trade in copra, rattan, waxes and gums and resins, oils and hides, and (in the case of the coast villages) dry fish and salt, beche de mer, and tortoise-shell.

It is enough to recall the fact that Macassar, which centralises a large proportion of this trade, though not all, exported in 1907 I6,030 piculs of coffee (I9,230 cwt.), 76, II9 piculs of rattan (91,342 cwt.), 90,949 piculs of copra (ro9, I40 cwt.) ; 2,29I piculs of pearl-shell or motherof-pearl (2,739 cwt.), I5,967 piculs of hides (I9, I6o cwt.), 7,0 3 piculs of nutmegs (8,4I4 cwt.), and 34I,393 piculs of copra $(409,670 \mathrm{cwt}$.) ; and that a rapid increase has been visible in the exportation of all these materials. 
For Celebes to become a really rich and prosperous country the first necessity is peace. The coasts are already practically pacified; but the country will never be completely and finally at peace until the Toradjas of the interior renounce their barbarous customs and commence to cultivate the soil. The greater part of Celebes is still virgin soil ; peace and order, once established, would enable the natives to break it up for cultivation, while the population, decimated by headhunting, would have an opportunity to recuperate itself. Such recuperation would be an innovation, and a very necessary one, for although there is abundance of fertile soil there is a serious lack of labour. There are good labourers on the coast, but their numbers are quite insufficient.

Lastly, Celebes has insufficient means of communication. There is a good road from Macassar to Boni and Maros in the south; another runs northward from Menado to Amurang and Tondano. These roads are certainly of great value, but they are as nothing compared with the area of Celebes. There remains the sea; but the windings of the coast make the coasting-trade a lengthy and at some seasons a somewhat risky business. For this reason, a canal cut through the isthmus of Palu would be of inestimable service.

The reclamation and civilisation of Celebes will be a stupendous task, but one that may end in magnificent results. Holland has already applied herself vigorously to her programme of development. 


\section{CHAPTER XVII}

\section{THE MOLUCCAS AND NEW GUINEA}

I. Physical geography of the Moluccas.-II. Their inhabitants.III. The Dutch in the Moluccas.-IV. Administrative divisions : (a) The Residency of Ternate and dependencies; (b) The Residency of Amboin.- $V$. The Residency of the West of New Guinea.-VI. The economic future of the Moluccas.

I.

ON the west the Moluccas ${ }^{\text {' }}$ are divided from Celebes by the Sea of Celebes. Eastward a mass of islands and islets, some of which are inhabited, connects them with New Guinea. The Philippine Sea washes them on the north, and the Sea of Banda on the south, while the Sea of Seram divides them into two distinct groups, of which the Dutch Government has made two Residencies. The Northern Moluccas form the "Residency of Ternate and its dependencies," and the Southern Moluccas form the "Residency of Amboin."

The Northern Moluccas, with their dependencies, have a total area of some 176,100 square miles, and a population of 108,900 inhabitants. The Southern Moluccas, with an area of 19,8 Io square miles, have a population of 299,000 .

"Little is known as to the origin of the name "Moluccas." The Portuguese called these islands the Maluco Islands, believing Maluco to be the name of their king as well. As in Arabic-the language of Islam, which had reached the Moluccas-the word for king is melek (plural muluk), and as each island had a king, old writers spoke of the Moluccas as "the Islands of the Kings." 
Both groups are essentially volcanic in character. The volcanoes of the northern group are far more active than those of the southern; the magnificent Mount Ternate, sung by the Portuguese poet Camoëns, being that most subject to eruptions. The Moluccas are the home of continual shakings and tremblings of the earth; the towns and villages are often littered with débris, in the midst of which the inhabitants are philosophically building new houses, neither the old buildings nor the new being particularly costly. The highest volcano in the Moluccas is on the little island of Tidore; its summit attains an altitude of 5,600 feet.

In islands of such limited area and irregular outline the rivers are naturally hardly worthy of notice. They have neither the width nor the length nor the abundance of the rivers of Java, Borneo, or Celebes, as, apart from their shortness, the rains are not heavy; yet the streams of the Moluccas, especially those of the southern group, are at all events numerous enough, and rich enough in rapids, falls, and little lakes to fertilise a soil already rich in volcanic humus, and to create landscapes of a wild and virgin beauty.

The climate of the Moluccas is much drier than that of Borneo; drier even than that of Celebes. In its freedom of perceptible moisture it recalls the climate of Australia; but this dry heat, tempered by the seabreeze, renders the islands extremely healthy.

The flora, which emphasises the peculiarity of tropical vegetation, in that it is far richer in foliage than in flowers, although the evidence of the hothouse often leads the inhabitant of the temperate zones to imagine the contrary, is, on the whole, more characteristic of Australia than of India; but the palm, the nutmeg, and the clove abound.

The fauna, like the flora, is reminiscent of Australia. The panther, the tiger, and the elephant are absent; but a number of marsupials occur. The glory of the fauna resides in the multitude of birds and butterflies, decked in the most brilliant of colours, which seem to vie 


\section{THE MOLUCCAS AND NEW GUINEA 341}

with one another to make one forget the scarcity of flowers.

II.

Although the total population of the Moluccas * is small, it is curiously mixed in character, owing to the isolation of its several divisions and the reputation of wealth which the islands have enjoyed from of old. The natives, obviously of the Malayo-Polynesian race, and forming a transitional phase between the Indonesians of Java, Sumatra, Borneo, and Celebes and the Papuans of New Guinea, have received the general denomination of Alfours, although they are not identical with the Alfours of Celebes. To say that a tribe of the Moluccas are Alfours is equivalent to saying that they are semi-savages.

These semi-savages present many points of difference, accordingly as they are dwellers on the coast or in the interior. In the Moluccas of the northern group many Malay and Bugis emigrants have settled on the coast, notably on Ternate and Tidore. These have intermarried with the women of the Alfours, and have founded a Mahomedan race of superior civilisation, which is found throughout all the lesser Moluccas, in Batjan and Kajoa, and on the southern coast of Halmahera. Beside these we must place the "Orang Serani," who profess a firm but much adulterated Christianity, and assert that they are the descendants of the Portuguese, the former masters of the country. These descendants of the "whites" are much darker of skin than the Malays or the Alfours ${ }^{2}$ but they speak a Malay dialect mixed with Portuguese words, pride themselves on a certain degree of civilisation, and, in order to mark their noble descent, always wear the black clothes and insignia re-

* Concerning the Moluccas, see K. Martin's Reisen in den Molukken, in Ambon, den Uliassern, Seran und Buru: (a) Eine Schildernng von Land und Leuten; (b) Geologischer Theil (Leyden, I894-1903, 4 vols., large $8 \mathrm{vo}$ ).

2 We observe the same phenomenon in many parts of the world; for instance, among the Portuguese half-breeds of Cambodia, and in the Malacca peninsula. 
served for chiefs. This does not prevent the majority of them from living idle and poverty-stricken lives.

It is only in the central parts of the islands-and especially in the northern part of Halmahera-that we find the true Alfours, who have remained animists, and whose civilisation is rudimentary. Nevertheless, their manners and morals are said to be pure and gentle; they are innocent of the barbarous rite of head-hunting, of the custom of enslavement in payment of debt (or at the most the slavery is only temporary, being limited to a term of ten years, and the debtor does not leave his own village, where, considering the solidarity of communal village life, it is not likely that his lot can be very hard).

Marriage is exogamic and patriarchal ; polygamy does not exist; nor may wives and daughters be sold to pay the debts of the husband, although the latter may become a slave to pay those of his wife.

The Alfours of Halmahera chiefly worship the spirits of evil, whom they seek to conciliate by offerings; and also the souls of their ancestors, whose survival they see in all things. They have a custom of slightly chipping or cracking any newly bought pots or vessels, which is probably observed in honour of their ancestors, with the idea of giving them their share.

We find, among the Alfours, even among those of the coast, who are converts to Islam, a singular ordeal, which is also practised by the Bahnars of Indo-China, in the same manner and in the same circumstances. When an Alfour is accused of any crime or offence-the offence is usually that of having "sent a doom," of having meddled with fate, and thus of having killed a fellow-villager-he may obtain an acquittal if he protest his innocence while drinking "the water of the sword"; ${ }^{\text {I }}$

× The Kings of Cambodia make all their officials drink "the water of oaths" upon assuming office, and also on their birthdays. This is consecrated water into which the king's arms have been dipped. In theory the perjured functionary should die as the result of the draught if he does not intend to keep his promise of fidelity as he drinks. 


\section{THE MOLUCCAS AND NEW GUINEA 343}

-that is, water contained in a bowl in which two swords have been crossed, a bullet having been thrown in first. In the event of perjury the offender will surely die.

The Alfours of the Southern Moluccas resemble the Papuans of New Guinea still more strongly than those of the northern group. Between the Alfours of Ceram and Amboin there are several strongly marked points of difference.

Amboin (Ambon), owing to the fact that Europeans and Malays have been established there for centuries on account of its trade in spices, is notable for a much higher standard of civilisation and comfort than that of the other islands of the Archipelago. In the south of the island Christianity is the prevalent religion; but the natives of the northern portion, who have not come under its influence, have embraced Islam.

In Ceram the Alfours of the seaboard are mostly Mahomedans, except those who live on that part of the island which faces Amboin, which is inhabited by the Orang Serani. These natives, who were converted to Catholicism by the Portuguese, only to be hustled into Protestantism by the Dutch, continue to mingle the two forms of religion with a naive and fervent eclecticism, and are especially proud of being Christians and "sons of whites." In the interior of the island the Alfours have remained barbarians, and are warlike and ferocious.

They do homage to spirits both good and evil, but especially to the latter; and they believe in the existence of a creative spirit, with whom they do not greatly concern themselves. Their priests are of the medicine-man type ; their religion consists in a number of superstitious practices, very often of a restrictive kind; it includes innumerable "taboos," and also sacrifices and offerings which are often entirely out of proportion to the modest possessions of the suppliant. The political power conceded to a few of the hereditary chiefs is inconsiderable.

Marriage, which is rigorously exogamic, and in which the woman is definitely adopted by the clan of her 
husband, necessitates the purchase of the wife, whose children belong to the clan and also to the husband. A widow should, if possible, remarry with a friend of the deceased, but at all events within the clan. Her fate is a happy one, compared with the general fate of other women of the Archipelago. Not only is she greatly respected by her husband; she is saved the heavy physical labour which elsewhere causes barrenness and premature old age. Although they hold quarrels, slavery, and usury in abomination, the Alfours of central Ceram must by no means be regarded as lambs: as witness the existence of head-hunting and of the kakehan. The kakehan is a secret society which groups the entire male population of Ceram about three chiefs, whose prescriptions they must blindly obey on pain of death. Its object is the maintenance of old usages against the influence of foreigners, and of Europeans in particular; and its members must help and succour one another at all times, but especially in time of war. The "cutting of heads" as trophies is an act greatly admired by members of the league. All affairs concerning religion and the social organism are discussed by the members of the league met in general assembly, the three chiefs presiding. Such meetings are held in the communal house of the league, which no woman may enter. There also they hold their banquets, and perform the ceremonial tattooing of warriors.

This league, as the agent of barbarism and revolt against the power of the Dutch, is naturally most carefully watched by the Dutch Government. ${ }^{\text {I }}$

In Buru, on the contrary, the Alfours are extremely docile. Those on the coast have mixed with the Malays; those of the interior are said to entertain a terror and a religious horror of the sea ; in their beautiful teak forests and their fertile plains they live a peaceful, agricultural life, cultivating their earth-nuts and sago-palms, and extracting oil of cajeput. They have a high reputation for loyalty and industry.

× See T. J. Bezemer, Door Inderlandsch Oost-Indië, p. 600. 


\section{THE MOLUCCAS AND NEW GUINEA 345}

Banka, which suffered so terribly of old from Dutch brutality, still owes to Holland the most defective side of its social organisation. It retains even to this day a group of perkeniers, $\mathbf{I}$ the descendants, after a period of nearly three hundred years, of those to whom the brutal Jan Coen distributed extensive holdings after having caused or permitted the massacre of numbers of inoffensive natives.

Their veins, at this late period, largely filled with native blood as the result of continual "crossing," the perkeniers form a kind of superior caste, which holds the native in contempt, and in matters of precedence ranks immediately below the island's few European officials. Next to them come the Christian natives, who were always treated as equals by the Company, and lastly, the common people; who, according to all observers, are far superior in morality, industrious energy and morality to the first two classes.

\section{III.}

The Southern Moluccas, being "spice islands" par excellence, were one of the most fruitful conquests of Portugal in the sixteenth century; and one of her possessions which Holland sought by all means in her power to wrest from the Portuguese at the end of the seventeenth century. She succeeded, and gained a source of wealth that appeared inexhaustible. For more than a century the spices of the Southern Moluccas yielded her a profit of 300 per cent.

The wealth of these islands was also the cause of some odious and abominable actions, such as are happily not common in her colonial history. To ensure that the superabundance of spice-bearing trees in Banda and

- From the Dutch perkere = "parcels, lots of land." These lots were distributed for the first time in 1627 by Jan Coen to various persons (perkeniers), who were required to plant them with nutmeg-trees, cultivate them, and sell the produce to the Company at a rate fixed by the latter. 
Amboin should not lower the prices, and in order to ensure itself in a systematic manner of the monopoly, the Company laid waste all the plantations of Banda and a portion of those of Amboin, forbidding the natives upon pain of death to preserve or replant them; and the death-penalty was declared also against any native who should be found attempting to sell the smallest parcel of spices to any foreign trader, who would himself be killed if captured. Moreover, agents extirpateurs-literally extirpating agents-were maintained in both islands, for the purpose of watching the plantations and of limiting them in the desired degree. The natives, on the other hand, were constrained to devote their time to cultivating and gathering the spices for the Company's benefit, with the result that they had no leisure to think of their own subsistence, and suffered from famine amidst the wealth they were producing for others; whence arose natural deceptions, revolts cruelly suppressed, and the rapid depopulation of Banda and Amboin. Fortunately for these unhappy folk the spice trade was ruined by foreign competition, and the Company failed. Finally a more equitable government was established, while Christianity brought them face to face with a less repugnant aspect of Western civilisation.

It is by means of Christianity that the greater part of these quiet and amiable populations have become the most dutiful and even (as in Amboin, for instance) the most loyal and affectionate subjects of the Dutch Government.

Installed in Ternate in 1607 , the Dutch had to proceed with greater circumspection in the Northern than in the Southern Moluccas, on account of the power of the Sultan of Ternate. Moreover, the inferior fertility of these islands could not ensure them the same enormous profits as those derived from the southern group. In the fifteenth and sixteenth centuries the Sultanate of Ternate won peculiar renown in Europe, and became enormously wealthy, by the sale of spices and by piracy. Holland was at first unable to benefit by the one, and had always a prime interest in suppressing the other. 
IV.

For administrative purposes the Moluccas are now divided into two Residencies.

The Northern Moluccas, to which we must add the Obi, and Sula, and Banggai Islands, the numerous groups between Halmahera and Dutch New Guinea, and the western portion of New Guinea itself, all go to form the Residency of Ternate and its dependencies (Ternate en Onderhoorigheden). Its capital is Ternate, and it includes the districts of Ternate, Labuha, Sanana, Galela, Banggai, Sakita, Manokuari, and Fakfak.

Ternate (Tarnati), the capital of the whole Residency and of the district of the same name, a town of 3,616 inhabitants, of whom 394 are Europeans, 721 Chinese, and 286 Arabs, is only the shadow of what it has been. It consists of the town proper, with its three wide parallel streets, connected by lanes which run between the kampongs of the Chinese, the Macassars, and the Christian natives, who as such are regarded as freemen and burghers (Inlandsche burgers). In these three streets are the public buildings; the Residency, the prison, the school, the church, and the Government stores and warehouses, all under the shadow of Fort Orange (Oranje), which was built in 1717 , and still contains a small garrison.

Next to the Macassar quarter are the lands of the Sultan, on which all the wealthy and notable natives and the princes are required to dwell. The palace itself is built on the top of a little hill ; it is a stone building, very large and handsome, provided with a verandah from which one obtains a splendid view of the sea. A wide lawn precedes the flight of thirty-four steps which lead up to the palace, which is a remarkably fine building as compared with the present decadence of Ternate. The sovereign has his own jetty and landing-stage, far removed from the common herd; but the new roadstead, which is so disposed as to avoid the fate of the old, which became 
blocked with sand, and formerly stretched as far as Fort Orange, has its entrance in front of the Residency. Despite its past, its healthy climate, and its proximity to Celebes and the Philippines, Ternate is visibly decaying ; it lives entirely by a purely local trade, principally with New Guinea. When the Americans are firmly and permanently established in the southern Philippines it is possible that a trade will spring up between these islands and the Moluccas, and awaken the port to renewed activity.

The district capitals seem to share in the somnolence of Ternate. Labuka $(7,529$ inhabitants) in the island of Batjan, despite the presence of a fort-Fort Barneveldt -a Protestant church, a native school, and a povertystricken Sultan, is only a handful of fishermen's kampongs. The only kampong which exhibits any activity or betrays any wealth is of course that of the Chinese.

Tidore (Tidori) is a Sultanate dependent on the Residency of Ternate, which includes a number of small islands-Matara, Marei, Filonga, Gebe, the Fau and Gag Islands, and the western portion of New Guinea as far as longitude $\mathrm{I}_{4} \mathrm{I}^{\circ}$ east of Paris.

Sanana, capital of the Sula Islands, 2 between Ternate and the Gulf of Tolo, is barely alive, despite a fine and secure roadstead off the island of Sulabesi. Galela, in the large but almost desert island of Halmahera or Gilolo, 3 has only I98 inhabitants, nearly all Mahomedans, who live partly on fish, partly on rice, sago, maize, \&c.

Banggai (Bangaai), containing 1,500 inhabitants, the capital of the islands of that name, all of which are

x Concerning the Residency of Ternate see F.S. A. de Clercq, Bijdragen tot de kennis der residentie Ternate (Leyden, $1890,8 \mathrm{vo}$ ).

2 The Sula Islands consist of a group of three large and a number of small islands belonging to the Sultanate of Ternate. The three large islands are Taliabu, Mangoli and Sulabesi. Lifumatola is the most notable of the smaller islands; numbers of swallows' nests are found there, which are gathered for the Sultan.

3 Or Djilolo, Djailolo. Gilolo is really the district of the western coast of the northern peninsula of the island of Halmahera, but the name has been wrongly extended to the entire island. 
inhabited, which is no slight merit in these seas of desert islands, and are dependent upon the Sultan of Ternate; Banggai, with its muddy paths, and its wretched wooden houses, is a poor village of fishermen and salt-workers. A dilapidated mosque and a rajah worthy of the mosque are not sufficient to increase its prestige. Sakita or Tobungku, on the eastern coast of Celebes, administered by a rajah and several chiefs, is the capital of a little State which has for a long time been a dependency of Ternate; Manokuari (II9 inhabitants), and Fakfaks (693 inhabitants), both district capitals of Western New Guinea, are principally of ethnographical and political interest; their economic value is merely rudimentary.

\section{V.}

The Residency of Amboin (residentie Amboina), which embraces the Moluccas of the South and their dependencies, is very much wealthier than that of Ternate and has very different prospects. It includes the following islands : Amboina, 1 Oma (Haruku), Honimoa (Saparua), Nusa Laut, Buru, Manipa, Kelang, Boano, Ambelan, Ceram, the Banda group, the Aru, Kei, and Tenimber Islands, Sera, Bubar, Leti, Moa, Leikor, Kisar, Roma, Damar, Wetar, \&c.

Amboin (Ambon), the capital of the Residency and of the island of Amboin, 2 contains 8,328 inhabitants, of whom 879 are Europeans, 539 Chinese, and 277 Arabs. The town still feels the benefit of the general prosperity which the spice plantations formerly brought

I Amboina, the name given to the island by the Portuguese, is undoubtedly derived through the Malay embon (embun, ambun), a dew or mist, from the native name Nasa Yapoono, "Isle of Mists." The Dutch have retained the form Amboina as applying to the Residency, while they habitually use the form Ambon in speaking of the island and its capital. In Malay the island is known as Pulau Embun.

2 Concerning the mineral wealth of Amboin see R. D. M. Verbeek's Descriptive giologique de lîle d'Ambon (Batavia, 1905, 8 vo, illustr., separate plates and atlas). 
to all ; in some quarters the houses of the natives, and especially those of the chiefs, are as spacious and as well furnished and decorated as ever, and the garments of both men and women, and their numerous trinkets of gold and silver, are visible proofs of an easy and comfortable existence.

Christianity, which is very general, has given the Amboinese a degree of civilisation greatly superior to that of the rest of the Moluccas. The climate is very healthy; the town, situated between Wai Tomo and Wai Gadjah, is of regular formation, clean, and a delight to the eyes. It is overlooked by the Nieuw-Victoria fort, which is built on the shore, and which protects the barracks and a considerable garrison; for Amboin is the seat of the military command of the Moluccas. The houses and offices of the Europeans are to the east and south of the port; near by is a fine Residency, the club, the church, the orphan asylum, the schools, and the prison. The native kampongs are distributed with less regularity, being scattered in almost all directions, although most are built fronting on the river. Amboin has been a free port since 1854 .

Saparua (2,354 inhabitants, of whom 299 are Europeans) situated on one of the islands in the Banda Sea, is a busy port protected by a small garrison, for in $18 I_{7}$ it was the theatre of a desperate and bloody revolt against the Dutch power. Since then Saparua has been completely pacified, and appears to be particularly loyal to Holland. Kajuli (526 inhabitants), and Tifu or Masaretei (543 inhabitants) are two district capitals on the island of Buru. Banda-Neira (4,130 inhabitants, of whom 677 are European and 306 Arab-there are only a few Chinese), whose name wakes the memory of the Portuguese, and the capital of the Banda group, is built on a site of marvellous beauty, which is often enhanced by the curious phenomenon of the Sea of Milk, a tract of water some miles from the shore, which at certain seasons covers the waves with a milk-white phosphoresence, due to the presence of myriads of tiny organisms. 


\section{THE MOLUCCAS AND NEW GUINEA 351}

Banda was the first of the Moluccas to have dealings with the Dutch (in 1599); and although it suffered greatly in consequence, it seems to have forgotten the past to-day.

Wahaai or Orang $(2,850$ inhabitants) in the island of Ceram or Serang is situated to the east of the Bay of Sawai. It possesses a small redoubt and a garrison. Tual (802 inhabitants), the capital of the Ewab or Kei Islands, is in a state of gradual development, thanks to the exportation, by Europeans, of building timber and ornamental hardwoods.

It has seemed best to attach the Residency of the South of New Guinea (Zuid-Nieuw-Guinea) to the Moluccas. The capital is Merauke ( 487 inhabitants); a place of no interest save to the ethnologist.

\section{VI.}

To sum up : except for spices and the plumage of the birds, $\mathbf{x}$ which are exported solely to Europe, the latter being in great demand on the French market in particular, and the subject of a long-established trade, the Moluccas have hitherto lived upon purely local resources : fish, swallows' nests, trepang, tortoise-shell, various kinds of hardwood, sago, \&c. Is the trade of these islands capable of expansion, and is it possible to improve the economic conditions of these islands? The reply should perhaps be different, accordingly as we consider the northern or the southern group.

The Northern Moluccas, sparsely populated and insufficiently cultivated, have no prospects worth mentioning, except that once an active and regular trade has been built up between Celebes and the pacified Philippines they may serve as a point of call, and may themselves take part in that trade. The Southern Moluccas, on the contrary, being better organised, more densely

- See T. Forest, senr. : Contributions ornithologiques de la NouvelleGuinée ou Paponasie a lindustrie de la mode in the Revue des Sciences naturelles et appliquées (Paris, 1894, 8vo). 
populated, and favoured with a better climate and a more fertile soil, may well enrich themselves further by the cultivation of spices, which at several points is now being undertaken by private individuals or companies, and the still more profitable cultivation of coffee. It is greatly to be desired that the natives should be awakened from their indolence by the public or private activity of the European planters. 


\section{CHAPTER XVIII}

\section{TIMOR AND ITS DEPENDENCIES-BALI AND LOMBOK}

I. The physical aspect of Timor and the character of its inhabitants.-II. The dependencies of Timor: Flores, Solor, Alor, Sawu, Sumba.-III. Administrative divisions of Timor and its dependencies.-IV. Bali : the island and its people.-V. Lombok : the island and its people.-VI. The establishment of the Dutch power in Bali and Lombok: the administrative divisions, and the future of the Residency.

\section{I.}

Celebes, the Moluccas, Dutch New Guinea and Borneo lie on the arc of a vast circle, one extremity of which, if produced, would pass through the centre of Sumatra. On another such arc, intersecting the former and of greater curvature, lie Sumatra, Java, and Dutch New Guinea; and on that portion of the arc between Java and New Guinea lie Timor and its dependencies, the Flores group, Bali, and Lombok.

The Residency of Timor and its dependencies (Timor en Onderhoorigheden) is divided into three districts :-

(a) Timor consists of the Dutch portion of the island of Timor, Alor, Sawu, Roti, and Semaru, and is divided into six sub-districts :-

I. West Timor, capital Kupang, and the islands Semau, Kera, Kambing Dilha, Tabuin, Burung, and Tikus; 2. Central Timor; 3. Belu; 4. Alor or Ombai, with the Pandai or Pantar Islands; 5. Sawu (Savu) and the small surrounding Islands; 6 . Roti and the adjacent islands. 
(b) Sumba (Tjendana-in Sanscrit chandana = "santal"), or Santal- or Sendal- or Sandal-wood Island (Sandelhout-Eiland).

(c) Flores, with the Adunara, Solor and Lomblem (Kawula) Islands.

With the exception of those to the east, these islands are commonly known as the Lesser Sunda Islands. ${ }^{x}$

Timor, or rather the western and most important portion of the island, has long been a bone of contention between Portugal and Holland. Holland, desirous of feeling herself mistress in her own house, after having consented to the greatest sacrifices that she might obtain the retirement of England from the Dutch Empire, made on several occasions the most tempting offers to the Portuguese, seeking to induce them to relinquish the portion of Timor which they retained. She was finally obliged to content herself with the treaty of delimitation signed in 1899 , which put an end to disputes, until then incessant, as to the frontier. ${ }^{2}$ Of a total area of II,230 square miles, supporting some 700,000 inhabitants, Holland obtained less than onehalf of the territory-namely, 5, I74 square miles-and about one-half of the inhabitants, with its dependencies, Dutch Timor has an area of about I8,000 square miles, and a population of 308,600 souls, of whom 249 are Europeans, and I,568 Chinese.

" Sunda is a geographical name, and does not signify "sound."

${ }^{2}$ A region concerning which all ethnographical and sociological information was wanting, the Portuguese portion of Timor is at the present moment the object of a searching inquiry. This has been undertaken by order of the Governor and at the suggestion of Senhor Osorio de Castro, President of the Civil Court of Dilli, who has undertaken the distribution of a series of questions, principally of a juridical or sociological nature. Senhor de Castro has also just published a most curious and interesting book, Flores de Coral (Dilli, I9Io, 8vo), a collection of poems, the Indonesian terms and local allusions being explained in long notes full of novel information due to personal observation. Such activity is an excellent symptom, and we may hope that Portuguese Timor will soon be as well known as the Dutch portion of the island. 


\section{TIMOR AND ITS DEPENDENCIES 355}

The island runs north-east by east and south-west by west, and is traversed by a range of mountains, which is wider on the Portuguese territory than in the western portion of the island. The highest summit in the island is 8,300 feet high ; the highest in the Dutch portion is 5,600 feet.

The streams of Timor are numerous and abundant; but during the period of the eastern monsoon-that is, from May to October-they are liable to dry up almost completely. The landscape, until then laughing and verdant, takes on a shrivelled and yellowish aspect that is positively painful to see. But the beneficent western monsoon, which blows from November to April, makes all things quicken and put on their livery of grêen as by enchantment; and the natives, who await this renewal of vital forces in condition comparable to that of their forests, greet it with cries of delight and honour it by festivities.

As a result of the desiccating, almost Australian climate of the dry monsoon, the climate and the seasons of Timor are infinitely more definite in their changes than those of Java, Sumatra, or Borneo, and some people are scarcely able to endure the dry and healthy yet excessive heat.

The fauna and flora of Timor recall Australia, resembling those of India hardly at all; the species are small, the forms grotesque. Timor possesses no elephant, no tiger, no wild cattle (bos sondiacus or banteng), and only one variety of monkey; but there are hosts of enormous bats, some dangerous snakes, and crocodiles, which are revered by the natives, at least in Kupang, the capital of Dutch Timor.

The Roti archipelago, capital Baa, presents similar physical characteristics. Little is known even to-day of the inhabitants of Timor; the long disputes between Portugal and Holland permitted them, between the two adversaries, to contrive to an almost complete independence, which their warlike nature has enabled them in a great measure to retain to this day. As far as we 
can judge they are Malayo-Polynesians, with frequent admixtures of Papuan blood, so that in type and culture they approximate to the Dyaks of Borneo. They are divided into a host of tribes, which on account of certain ethnological peculiarities, and their own statements, have often been regarded as peoples of different origin; but they are now by general agreement divided into the Timorese (Atoni Timor), who inhabit the south-west of the island; the Belonese (Ema Belo) of the centre and east of Timor, and the Kupangs (Atuli Kupang), who are settled in the ancient kingdom of Kupang and in the island Semau (Samao, Samau, Samauw). The largest group, that of the Belonese, claim to have come from the Moluccas. Many are to-day Christians, at least in name, and a certain number are Mahomedans; but in the interior they remain animists worshipping the Sun and the Moon his wife, and paying homage to certain trees and rocks, and to the souls of the dead, whom they greatly fear. A little grove or thicket near the village conceals the protecting god, with whom only the sorcerer-priest dares to hold speech.

Extremely superstitious, the Timorese spend a great deal in sacrifices to the divinities, these sacrifices including living animals; and they fetter their whole lives with a host of prohibitive measures analogous to the Polynesian tapu or taboo.

Nearly all the Timorese tattoo themselves and file the teeth. Although independent to a fault, they recognise almost everywhere the authority of a hereditary chief of divine origin, who is regarded as immortal : he does not die, but sleeps. His corpse is often exposed on the branches of a tree in an open coffin; or the wives of the deceased chief will keep his body, during the period of putrefaction, in a kneeling position; and only when the flesh has decayed and the remains are reduced to a mummified condition are they buried, facing the Sun, the chief's "father." With the chief are buried a portion of his goods and his clothing: formerly the mourners would cut the throats of several of his slaves 


\section{TIMOR AND ITS DEPENDENCIES 357}

above his tomb, so that he should not go unattended in the land of dreams; but to-day he has to content himself with a dog as companion and guide. After the dead man has been covered with honours and presents, there is no precaution which the mourners will not take to avoid awakening the soul of the sleeper, and to prevent his returning to his old home, there to wander about and torment the living who inhabit it.

During the long disputes between the Dutch and the Portuguese on the subject of Timor and the surrounding archipelagoes, the natives were constantly encouraged by the one party to resist the other, with the result that European influence and European rule have but a feeble foothold on Timor. The whole island is shared between a host of petty rajahs, turbulent and insular, hating strangers; and the Christians are by no means the least hostile. Especially is this true of the "black Christians," the descendants of Portuguese half-breeds, whose pride in their noble origin and their Western creed has often the result of making them as intractable as they are treacherous. Yet while Portugal, should she persist, out of a comprehensible pride in her brilliant past, in remaining in Timor, has neither the necessary resources nor any genuine desire to put her colony in order, the Dutch have been at work for some years on their portion of the island; creating wealth by reclaiming the soil, ensuring the obedience of her vassals, and suppressing the slave-trade in all directions. Although the Dutch portion of Timor has a less fertile soil than the northern portion, the Dutch are slowly transforming their portion of the island into a magnificent plantation of coffee, tobacco, and sugar-cane.

II.

The Flores, Solor and Alor groups, all of volcanic origin and full of smoking or extinct volcanoes, are strung out between Timor and Sumba, with the Sea of Flores on the one hand and the Sea of Sumba on the 
other. These islands also were the object of disputes between Portugal and Holland until I859, when they finally fell to Holland. Their populations, analogous to those of Timor and Sumba, but crossed on the coasts with Malay and Bugis blood, are partly Christian, partly Mahomedan, partly animist. Closed to all Europeans while the Company was still in power, lest passing vessels should take up cargoes of the wild cinnamon which abounds there, and which might compete with the cultivated product of the Company, and then, like so many shuttlecocks, tossed between Portugal and Holland-a fate which for some time delivered them from eitherthese groups of islands have formed a section of the East Indies which is one of the least civilised and least known of all.

Sumbawa, to the south of Flores and west of Timor, and Sumba, or Sandal-wood Island, are scarcely better known. In both these islands, however, and in the physical aspect of their inhabitants, there are visible traces of a Hindu occupation, although the natives have long since fallen back into animism; but an animism free from the barbarous practices to be found elsewhere.

Timor, first colonised by ir vaders from Ternate, remained subject to the latter until the coming of the Portuguese in I520. The Dutch arrived in I613.

\section{III.}

To-day the Dutch portion of Timor and its dependencies forms a Residency whose capital is Kupang $(3,773$ inhabitants, including Io6 Europeans, 468 Chinese, and I78 Arabs). Built facing on a fine anchorage, it would be an extremely agreeable town were it not for the torrid and unhealthy climate. It contains a well-built fort and a considerable garrison, for the rajahs of Kupang, secretly excited by the Portuguese, formerly gave the Dutch considerable trouble, so that at one time the Government had no less than 14,000 troops in the island.

These rajahs profess to be related to the crocodiles 
which infest the shores of the islands; and it is said that they formerly used to strengthen their family ties by a curious ceremony. Whenever one of them ascended the throne his subjects used to throw themselves into the water to do homage to the king's relatives, and the first crocodile to emerge, and thus to admit the relationship, received as a reward a wife, in the shape of a richly dressed virgin, whom he promptly devoured.

To-day Kupang is occupied chiefly in exporting coffee, sandal-wood, horses, fruits, pearl-shells, sharks' fins, trepang, swallows' nests, and tortoise-shell.

Baa (Baä, Namuda, or Namudale), containing r, 083 inhabitants, on the island of Roti, is the capital of the district formed by that island. It carries on a small export trade in fish, wood, and wax.

Waingapu ( 1 r, 069 inhabitants), the capital of a district including Sumba and Sawu, which formerly prospered largely by the slave-trade which the Dutch have suppressed, exports little to-day but excellent horses and sandal-wood, although the precious sandal-tree has disappeared from the coasts, and is now found only in the interior of the island of Sumba.

Larantuka, the capital of the district of Flores, Solor, and Alor $(4,663$ inhabitants), is in continual touch with Celebes, whence it imports all its manufactured goods; sending in return fish, tortoise-shell, and cinnamon, in place of the numerous slaves which it used to furnish, and by so doing largely depopulated itself and the surrounding islands.

The future of the Residency of Timor depends entirely upon its effective pacification and submission, which will allow the Dutch to reclaim the soil. The soil of Timor in particular is noted for its fertility even in the Indies.

IV.

With the Residency of Bali and Lombok we return to the heart of the Indo-Javanese civilisation, and it is not only by reason of the similitude of its geological structure 
and its orientation that Bali, in particular, has earned the name of Little Java.

The two islands are almost equal in size, and their joint area amounts to 4,050 square miles, or slightly more according to some. Their joint population amounts to 525,565, including II9 Europeans, I,807 Chinese, and I43 Arabs. The last census betrays a regrettable depopulation, similar to that which some twelve years ago affected all the East Indies excepting Java. In 1900, in fact, the inhabitants of Bali and Lombok numbered $1,039,300 .{ }^{x}$

Bali, separated from Java by the narrow Strait of Bali, is, like the larger island, essentially volcanic in character. Its highest peaks are Tabanan (7,500 feet), the base of which is pitted with little lakes; Gunung Agung, or the Peak of Bali (10,400 feet, and Batur (7,350 feet).

The coast, full of inlets, but bristling with reefs and shoals, is unsafe and even inaccessible for a portion of the year. Temukus is the only port which can be entered and left at any state of the tide and at any time of the year.

The streams, plentiful though they are, have no time, within the limits of Bali, to attain any useful amplitude, especially as a great part of the surface of Bali is occupied by the mountains. The climate is that of eastern Java : hot but healthy, excepting on the south coast, where the swamps of the coast are reeking with fevers.

On this account, and because of the absolute contempt of hygiene manifested by the inhabitants, Bali has for years been the prey of periodical epidemics of cholera and smallpox, which are at last diminishing, owing to the measures taken by the Dutch Government.

x Concerning Bali and Lombok see W. O. J. Nieuwenkamp, Bali en Lombok, Uitvoerige geïllustreerde reisherinneringen en studies omtrent land en volk, kunst en kunstnijverheid (Edam, 1906, 4to).-R. Friederich, "An Account of the Island of Bali," in "Miscellaneous Papers relating to Indo-China and the Malay Archipelago," Second series, vol. ii., pp. 69-200 (London, 1887, 2 vols., 8vo).-J. H. van Balen, Lombok, Landen Volk (Helder, I894, 8vo).-J. J. Ten Have, Het eiland Lombok en zijne bewoners (The Hague, I894, 8vo). 
$\therefore$

is 3

$y+\frac{1}{2}$

120

se

1.

$13 \div 2 x^{\circ}$

$2+0$

a

$+x$

ats

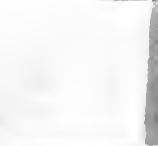

15.

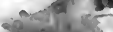

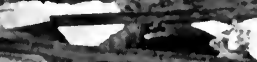
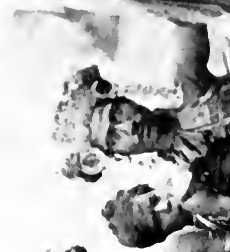

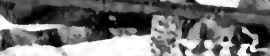

(v) 2

filinil $\rightarrow$

$\ln ^{2}=x^{2}-3$

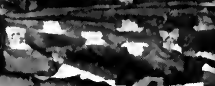

3

$+\infty$

ath
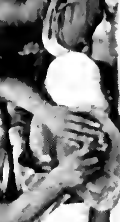

2).



- $0.100=$

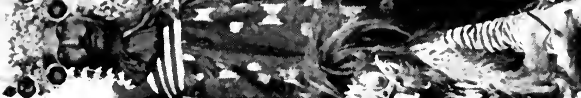

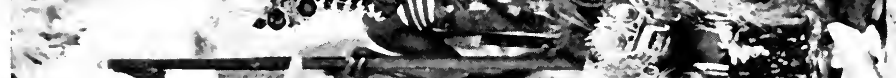

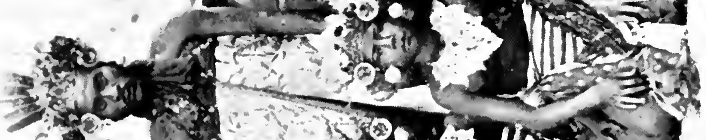

2
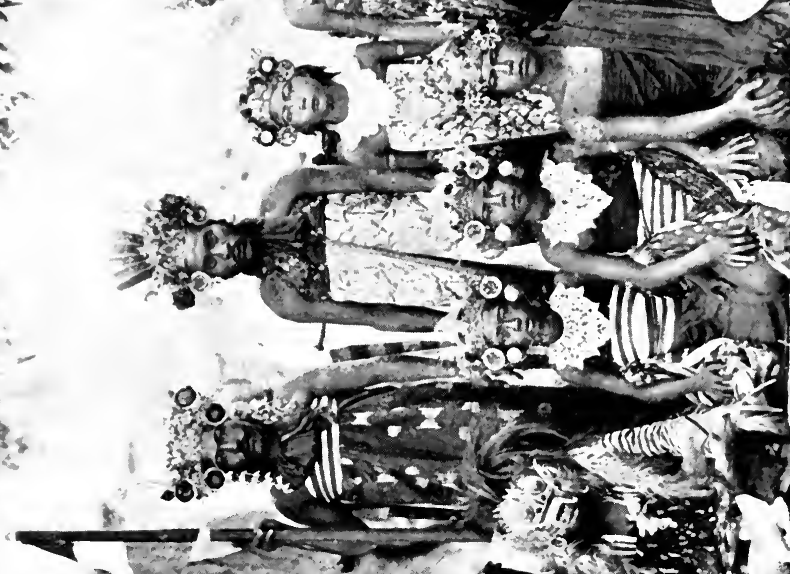

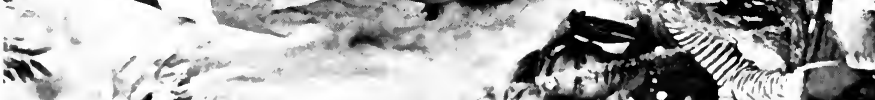

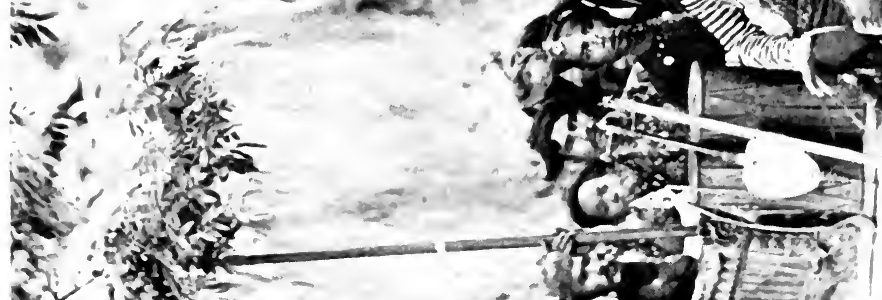

3.: 1 ist?

$\rightarrow x^{2}-x^{2}-\infty$

$5=2-20$

$4 t=21$.

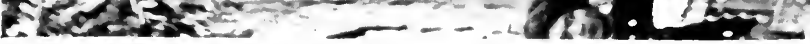



The flora and fauna of Bali are closely related to those of Java, and, like the latter, are half Indian, half Australian in character.

The island, thanks to the fertility of its soil and the frequent rains, has the aspect of a gigantic bouquet of verdure. There is, however, a lack or a scarcity of the larger forest trees; and although the teak-tree itself is present, Bali is obliged to import timber for constructive purposes. In compensation, the coco-palm, the origin of the preparation known as copra, and the lontar-palm are abundant.

The fauna is not so rich as that of Java : the rhinoceros and banteng no longer exist, but numbers of tigers roam the west and centre of the island; and the forests conceal many wild cats, and the musk-bearing chevrotain. The domestic animals-buffalo, wild cattle, horses, goats, pigs, \&c. - are the same as in Java.

The chief interest of Bali is archæological, and resides in the character of the inhabitants and their obstinate attachment to Hinduism after the lapse of centuries.

All efforts to convert them to Christianity or to Islam have hitherto failed, except among the very lowest classes, who are regarded as belonging to inferior races.

Bali, it seems, must have been visited at a very early period by the Hindus, who settled there and remained under the suzerainty of their compatriots at Madjapahit. Even to-day the majority of the Balinese proudly entitle themselves Wong Madjapahit (men of Madjapahit), in order to distinguish themselves from the Bali-aga or indigenous Balinese, who are dispersed over almost the whole of the island, and have not been subjected to Hindu influence.

After the fall of Madjapahit the element which had been converted to Hinduism, reinforced by the refugees from the Hindu empire, became still more arrogant and insular. To-day the population consists of the Wong Madjapahit, descendants of the aborigines and the IndoJavanese colonists who profess Hinduism; the Bali-aga, aborigines of a purer blood who have remained pagans, 
and on the coast the Balislam, natives crossed with Javanese and Madurese and converted to Islam.

Physically, the Wong Madjapahit are the finest and most handsome of these peoples. At once more robust and more slenderly built than the Javanese, whom they very closely resemble, they are also lighter in colour, and their eyes are keener; they have long arms and very narrow feet.

From the social point of view we find that Hinduism has endowed them with the oppressive caste system; a system which, in all that concerns people of Brahministic descent, is pitiless in its determination to maintain the purity of caste. But lately, if a Brahmin's daughter took a lover of inferior caste, she was put to death, and the lover, being sewn into a sack, was cast into the sea. The Dutch, wherever their authority reaches, have caused the substitution of banishment for this cruel punishment. They also prohibited sati or suttee; but when a prince or a Brahmin dies the family of his wife or wives move heaven and earth to evade the law, so that the wretched widows may enjoy the glory of burning themselves to death upon their husband's corpse.

Despite these practices, and a proud, bellicose temper, only too often excited to madness by the abuse of hemp (Cannabis indica), the Balinese are tolerant: they allow the lower classes to adopt Christianity or Islam, and the fact that they permit Brahmins to marry women of inferior caste without depriving the children of such a marriage of the caste of the father, is leading to a gradual levelling of social differences.

Externally the Balinese betray their Hinduism by abundant prayers and fasts of purification; by their respect for cow-dung and the five products of the cow, and their horror of beef and buffalo-meat. The only meat they eat is pork. Although they are Brahminists, and some even Buddhists, and although they erect effigies of the gods of the Hindu pantheon in their temples, it would be an exaggeration to speak of the Balinese as pure Hindus. Their religion is grafted on 
the animistic superstitions of the Malayo-Polynesian race, which are constantly showing through the newer cult, and which really form, under the Hindu ritual, their clearest and most definite beliefs.

Of the Hindu trinity, Shiva, with his sakti (wife or energy) Durga has become the supreme divinity of Bali : they have effaced Vishnu, Brahma, and their wives. Shiva, in the shape of Mahadeva, has his seat upon Gunung Agung, the highest summit of the island. Durga, in the capacity of a goddess whom the Hindus call Uma, "the Gracious," dwells in the Lake of Batur, at the foot of Mount Batur; whence her alternative name, Devi Danu, the Lady of the Lake; but as Kali and the goddess of death the Balinese represent her as a monstrous and hideous female; but she is chiefly honoured as the virgin Devi Seri-the goddess of agriculture-the Crri of the Hindus; the Ceres or Demeter of the Greeks and Romans. Agricultural rites, moreover, hold the most prominent place in the Balinese cult. The representations of Devi Seri in effigies of Chinese coins or kepengs sewn together are extremely popular. The old Polynesian gods or rabut sedana, to whom the Hindu gods are in reality everywhere subordinated, are also represented in the same way. All the temples have their special rabut sedana, not counting those reserved for Kali. At the back of the sanctuary a little house surmounted by from three to a dozen superimposed roofs, which is known as the Meru Mountain, shelters a couple of gods in kepengs; and the statues of the Hindu divinities, which are placed in the body of the temple, serve as guardians or rakshasas.

With the exception of Batara Baya (the Hindu Vayu) in whose honour some temples have been erected along the coast, the secondary gods of the Hindu pantheon are no longer the object of a special cult in Bali. Their statues are often encountered, but the people who give to all the general title of togog no longer distinguish their several characters. They hold by the rabut sedana guarded by Shiva, and the temples of the dead dedicated 
to Kali and Devi Seri the goddesses of the harvest, which are all that remain to them of their double past. ${ }^{x}$

V.

Lombok, the country of the Sasaks, to the east of Bali, from which it is separated by the Straits of Lombok, is less known than Bali, although it has been under the political domination of the latter since the eighteenth century.

Lombok, volcanic and mountainous like its neighbour, possesses in Rendjani or the Peak of Lombok (I2,290 feet) one of the most lofty and magnificent summits in all the Indies. The streams are as small as those of Bali, but so numerous that the eastern plains, where rice and coffee are the principal crops, are marvellously fertile. The climate recalls that of Bali ; the fauna and flora are more Australian than Indian.

The inhabitants of Lombok, the Sasaks, are all Mahomedans. They are not particularly fervent, nor have they many mosques; their religion consists principally in their being circumcised and refusing to eat pork. They eat no meat but beef : unlike their neighbours the Balinese, to whom the eating of beef would be sacrilege. The thousands of Balinese who have established their supremacy in Lombok and from the conquering caste treat their Sasak subjects with the most arrogant contempt.

The Balinese Rajah of Lombok reigns over a small portion of Bali also: namely, over the Government of Karangasem. He delegates his powers to a viceroy chosen from his own family.

The possessor of a capital little army, and an intelligent but extremely despotic ruler, the old sovereign of Lombok, who died only two years ago, was a very

× See C. M. Pleyte, Panthéon hindou-balinois in the Exposition universelle internationale de 1900 à Paris. Guide à travers la section des Indes Néerlandaises. Groupe xvii. (Colonisation), pp. 223-4. (The Hague, 1900, 8vo.) 
distinguished Asiatic sovereign. Thanks to a system of severe repression order reigned throughout all his possessions ; theft and adultery were punished by death, and the use of opium and games of chance by the bastinado. The Dutch Government alone was able to qualify his autocracy, without jeopardising such results of his policy as were of value.

\section{VI.}

Bali and Lombok were discovered in 1597 , by the brothers Houtman; but the extremely warlike nature of the inhabitants made their conquest a matter of great difficulty. Only in I743 did the Susuhunan of Surakarta cede his rights in Bali to the Dutch; but the island did not recognise the sovereignty of Holland until nearly a century later-in $184 \mathrm{I}$; and dangerous rebellion necessitated lengthy military expeditions in the years 1846 , 1848 , and 1849 . Even as lately as $18 \mathrm{r} \cap-1894$ the Dutch had to content themselves with the direct administration of the two Balinese provinces nearest to Java: namely, that of Djembrana and that of Buleleng or Singaradja. Over the other provinces-Bangli, Mengwi, Badung, Giaujar, Klunkung, Kerangasem-the Dutch had only a moral and little more than nominal influence. These provinces were governed by an alliance of rajahs who were absolute monarchs in their own dominions, and ready at a moment's notice to begin hostilities in the shape of an irregular campaign, a war of ambuscades and surprises, exceedingly dangerous to European troops on unknown ground, especially in a country infested with fever and covered by dense and treacherous vegetation.

The position of the Dutch in Lombok was no better. The arrogant Balinese, who forbade their subject Sasaks the right to bestride a horse upon their native island, looked with the blackest disfavour upon the irruption of powerful foreigners. The Dutch advanced prudently and adroitly, profiting by the complaints of the oppressed 
Sasaks or the lower-caste Balinese, and at need enforcing their representations by long and bloody campaigns.

In 1894 the military power of the princes of Lombok was finally broken by an expedition which cost General Michiels his life; the rajahs submitted and are now apparently loyal. But the princes of Bali were only defeated, and in 1908 another expedition had to be despatched to the latter island; and the wives of the rajahs, drunk with hemp or opium, have followed their lords into the field, and have flung themselves upon the bayonets of the Dutch soldiers rather than surrender to the victor. One cannot be certain that such scenes will never be repeated; for this stubborn race, despite the circle which is closing around it, appears to prefer death in freedom than life in subjection.

From the administrative point of view the Residency of Bali and Lombok forms three districts : the first has for capital the town of Singaradja $(8,727$ inhabitants, including 44 Europeans and 9I4 Chinese). This is the seat of the Dutch Resident; a huge overgrown village, with many native kampongs and fine public buildings. About two miles from Singaradja is Buleleng or Pabean Buleleng, a busy port with a population of Chinese, Arabs, Bugis, Madurese, and a few Armenians. Negara, the capital of the second district, has a population of $6,65^{\circ}$ only. Mataram, the capital of Lombok, formerly a very flourishing town, with Malay, Balinese, Bugis, Chinese, and Sasak kampongs, has to-day only three hundred inhabitants left. The inhabitants have left the towns, and are living on the territory of the rajahs, although the Dutch administration is everywhere doing its utmost to improve their lot.

The economic future of Bali and Lombok is necessarily bound up with that of Java. The best that can happen to either island is that it should one day be absorbed into the economic system of the larger island. The Balinese, who are poor sailors on account of the nature of their coasts, but excellent labourers, carvers, smiths, armourers, \&c., have, like the people of Lombok, every- 
thing to hope from the methodical cultivation of their unusually fertile soil ; when, instead of confining themselves to shipping copra and a few of their excellent horses, they would soon be able to export coffee, sugar, and tobacco of their own growing, and so open up a considerable trade with the outer world. 


\section{CONCLUSION}

WHAT will finally be the fate of Dutch colonisation in the islands of the East Indies? It seems that the past will answer for the future. The Dutch Indies, like all Asiatic colonies to-day, are tending towards autonomy ; but they are, for the moment, incapable of realising it unaided; nor could they do so with the help of any other nation of the Far East. They can attain independence only in the remote future, under the protection of the Dutch flag.

But even though the moral and intellectual qualities of the people of the Indian Archipelago, and of the Javanese and Malays in particular, may justify their hope of a freer future, it is very difficult to imagine that a common destiny could be shared by races so different, and ranking so unequally on the scale of civilisation, without either cohesion or unity. With all these peoples the political sense is very rudimentary. The Malays and Javanese were able to rise from the anarchical conception of semibarbarous tribes always at war to that of a host of autocracies, brutal and conquering powers; but not to the idea of a nationality, or even of a federation of states united by ethnological or linguistic affinities. This mental disability, which delivered them up to the Europeans, renders them still incapable of gaining freedom except at the cost of falling back into anarchy.

Thus the European theory that "the natives should be left to arrange matters between themselves" is simply puerile. The only way in which people "arrange" matters in any part of the world-but especially in the Far East-is, as history shows, by crushing the weak. The 
natives of Indo-China "arranged matters" by subjecting the Shans and the Cambodians to the brutal tyranny of the Annamites: the people of the Indian Archipelago "arranged matters" by means of Malay and Achinese invasions, chronic piracy, head-hunting, ritual murclers, incessant warfare and depopulation and mental degeneration on every side. To pretend that a European domination, even with its regrettable blunders and failures of justice, is not for the good of such peoples, is to deny the past, to deny the petition of the victims in favour of the complaint of the privileged despoiled of their privileges.

Could any great Asiatic nation do more for the Indies than Holland has done? The idea is inadmissible.

Since the Russo-Japanese War certain Gallic enthusiasts have been extolling in the Japanese the very qualities that they most deplore in European peoples : a warlike spirit, an ardent nationalism, a heroic and indefatigable ambition: and have suggested that Japan will rapidly become possessed of Indo-China, the Philippines, the East Indies, and even China. Even did the childlike candour of the French induce our Japanese allies, by such indirect invitations, to install themselves in French Indo-China, it is possible that China, America, and Germany would scarcely encourage their ambitions, and at need might quiet them. It would be as Utopianforgetting the lessons of history-to give all the "yellow" races of Asia and the "brown" races of the Archipelago to Japan in the name of vague racial affinities as it would be to suggest that Spain should be given to the Hungarians, because both Spaniards and Hungarians are Europeans.

What the Asiatics admire in Japan is that she has been able to assume the civilisation of the West. But it is permissible to believe that Europeans still retain the complete comprehension of their own civilisation, and are likely to initiate other nations with greater humanity. The brutal denationalisation of Corea proves as much; and it is certain that no Asiatic people is anxious to furnish a second example. 
The European balance of power makes it eminently desirable that the East Indies should remain the property of Holland rather than of England, Germany, the United States, or France.

Again, what do they not mean to the Dutch? The Dutch have for three centuries lived in the Indies, developed with the Indies; to-day they know them through and through, and love them as their most precious jewel, the very source of their wealth and greatness.

It is true that in the seventeenth and eighteenth centuries, and even in the first half of the nineteenth century, the Dutch administration was far from irreproachable; in which it resembles the administration of all other colonial powers.

We must recognise, too, that Holland confined herself to diverting to her own profit the system of abuses by which the local tyrants had lived before her arrival. In doing so she did what no moral and civilised nation should do ; but others have done worse. But as compensation for these undeniable errors, the Indies owe her not less undeniable benefits, even though the origin of those benefits was not always disinterested. The admirable economic development of the whole of Java, and of a great part of the whole Archipelago; the security of a strong and systematic organisation; a general humanisation of manners; the more and more effectual prevention of famines; the population of Java increased to ten times its original dimensions, and an increase of population throughout the islands: these are solid benefits.

We cannot accuse a country of unmixed cupidity, of a purely selfish exploitation, when the Government of that country spends more than $f_{1}, 000,000$ annually on the pensions of notables and the salaries of native officials, and more than $£ 280,000$ annually on the education of those very natives-far more for the benefit of agriculture than for the upkeep of repressive military force. How many colonial powers can boast of having done more, or even of having done as much? 


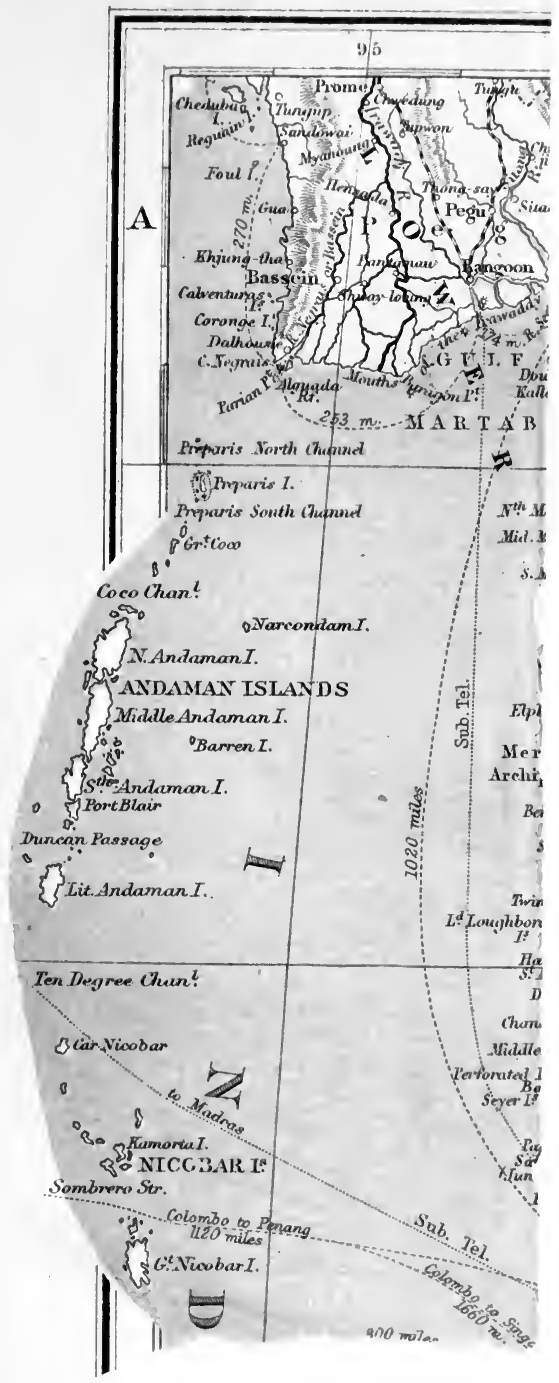



We see little Holland holding in subjection peoples who are beginning to be aware of their numerical strength. To gain their hearts, she has only to suppress the absurd disdain which certain colonists feel for the native; those imbecile insults and annoyances to which they would not dare to subject the meanest of their compatriots, and which the "browns" do not like any better than the "whites" because they have for centuries been compelled by force to endure them.

The native aristocracy, whose power over the people is already so great, are in all loyalty aspiring towards the knowledge and culture of the West. It would be exceedingly dangerous to wound them by a sullen hostility the moment they commence to produce individuals capable of equalling Europeans and capable of assimilation with them. Those who, in the Indies and elsewhere, can see in the brilliant disciple of to-day nothing but the possible rival of to-morrow, and in their dangerous jealousy repulse him and refuse their loyal collaboration, are most surely preparing the way for the eventual emancipation which they dread. If the Indies have need of Holland, Holland has an even greater need of her colonies, the source of her commercial stability and her political power.

Her character and a series of happy accidents have allowed her to play a part disproportionate to her size. The place which she won in Europe in the seventeenth and eighteenth centuries her colonies restored to her in the nineteenth century. In the possession of her splendid Indian empire she feels on a level with more powerful States; without them she would understand the bitterness of that saying of Leopold II. of Belgium: "It is such an infirmity for a country to be small!" This is why the Low Countries, whose courage and patriotism have long been famous, would shed the blood of their last soldier rather than abandon the Indies; and for this reason they feel each day more strongly the necessity of securing them by a civilisation of a wholly humane and civilising type. 


\section{INDEX}

Abrew, Antonio de, I2

Acheen, 288, 289, 295

Achinese, the, 266, 274-7

Achinese War, 153, 288

Adat, ro8-9, I4I, 208

Adjih Saka, 8

Administration, of Java, $189-203$; see Resident, Regent

Administrative Divisions, 57-100

Advisers for Native Affairs, $197-8$

Agriculture, II2, II3 ; coffee, I83 ; history of, 205 ; rice, $213-16$; coffee, 219-24; sugar, 224-8 ; tobacco, 228-3I ; tea, 23I-3 ; quinine, 233-5 ; indigo, 236-7 ; pepper, 238 ; opium, 238 ; agriculture in Sumatra, 303. See Exploitation, Land Tenure, Plantations, and chapters dealing with the lesser islands

Agricultural College, the, 212

Aji Saka, 9

Albuquerque, first Portuguese Viceroy, 12

Alexander VI., I2

Alfours, the, 34, 327, 329, 342

Almeida, 12

Aloun-aloun, ro8

Alor Islands, 357

Amboin, I2, 349-50

Amburawa, sinister history of, 68-9, 209

Amok, condition of, $3^{6-7}$

Amurang, 366

Anamba Islands, 28I

Angkor Wat, 72

Animism, 9-10

Anjer, destroyed by tidal wave, 261

Arabs, civilising influence of, 28, I 54 ; complaints against, $155-56$

Archæological Society of Djokjakarta, 73
Army, Dutch Colonial, 167-9

Asoka, 4

BALI, 359-67 ; Hinduism in, $362-3$; history, 365

Bamboo, 217

Bandjermasin, 320-1

Bandung, 64

Banjawangi, 98

Banjumas, 69

Banka, 28I-2 ; tin mines of, 300-I, 345

Banks, 246-7

Bataks, 34, 270-2

Batavia, 58-6I

Batik industry, $12 \mathrm{r}-3$

Bencoolen, 287, 289, 29r

Besuki, 87, 97

Billiton, $28 \mathrm{I}-2$; tin mines, $30 \mathrm{I}$

Birds, i 16

Blitar, 92

Borneo, area of, 26, 307 ; history, 308-9; geology, 309 ; rivers, 3 I0 ; climate, flora, fauna, 3II-I2 ; history, 3I7-I8; mines, 321

Boro-Budur, 7I-3

Brahminism, 8, I38

Brantas, Kali (River), 9I

Bridges, 249

Brooke, Rajah Sir James, 3I

Bruneï, 3I

Buddhism, 8, I38

Budget, the, 208

Bugis, the, 328-9

Buitenzorg, Botanical Institute and Government station, 62, 25I

CaBots, the, explorers, 14

Cabral, I2

Calicut, 12

Catholicism in Java, 138

Chancellor, founds the Russian Company, i4 
Cheribon (Tjirebon), 63

Chinese, the, 158 ; commercial habits, 159, 161-2 ; harshness of, 163 ; as colonists, 164 ; laws relating to, $165-6$

Chinese blood, admixture of, in Malay race, $\mathbf{1}_{34}, \mathrm{I}_{54}$

Christianity in Java, 140

Climate of Java, 52-3

Coco-palm and products, 216

Coffee, 183, 219-24, 303

College, Royal Preparatory, 200

Colonists, the Dutch, I68-88 ; houses of, 175-6; furniture, I77-8 ; food and clothing, I 78 $8 \mathrm{r}$; servants, 182 ; hospitality of, I83; social impermanence of, 185 ; preservation of the race, I 86

Columbus, II

Company of Distant Countries, 29

Company, Dutch East India, q.v.

Compulsory crops, 207-IO

Condiments, II 8

Coral reefs, meaning of, 2

Corvée, the, 207, 200-ro

Costume, native, I 23-5

Council of the Indies, 196, 200

Crops : rice, 213-16 ; maize, cocopalm, 276 ; fibre, 217 ; areca, 217 ; bamboo, 217 ; coffee, $219-$ 24 ; sugar, 224-8; tobacco, 228-3I ; tea, 23I-3; quinine, $233-5$; in Sumatra, 303

Crossing of races, $186-8$

Daendals, Marshal, I7-I8; his exploitation policy, I45 ; government of, $17 \mathrm{I}$, I9I ; road built by, 206 ; 248,284

Delft, Municipal Institute of, 201

Dekker, Edouard Douwes, I6

Deli, 286-7

Demak, history of, 67

Departments, Government, 196

Diamonds, 322

Dipo Negoro, rebel leader, 21

Djambi, 286, 293

Djember, 97

Djokjokarta, 82-3

Domestic animals, I I9-20

Drake, Sir Francis, I4
Dutch, arrival of, in the Indies, 29; seize Portuguese colonies, 30 ; policy of, I38 ; resume possession of Java, 192

Dutch East India Company, 138 ; bankruptcy of, I69; policy of, I69-17I ; replaced by Crown, I90, 285

Dutch, language, reserved for rulers, 42-4

Dyaks, 34, 312-17, 32 I

EAST INDIES, origin of, 2

Education, native, 2I, I44-53; demand for, I50-I ; budget of, I 53

Engineering works, 248-9

Engineers, practical, I86

Europeans in Java, I67-88 ; in the army, I67; other than Dutch, I72

Exploitation of the soil, early methods, 204-7 ; forced cultures, 207

Exports, 253

Fauna of Java, 35-6, II 5-20

Fisheries and fish, II6-18

Flores Islands, 347

Foreigners, census of, 154,167 ; regulations to be observed by, I $72-3$

Foreigners, Oriental, $155-66$

GaMes, I27

Gamelan, native orchestra, 127-8

Garut, 64-5

Gayos, the, 273-4

Generalities, 25-44

Geological structure of Archipelago, 32

Giri, 90-1

Gold, 297-300, 322

Gorontalo, 336

Governor-General, the, 195 ; powers of, I94; salary, 199

Grisei, 90-I

Gunung Guntur, 49

Hemp (Cannabis indica), abuse of, $36-7$

Hindus, invasion of, 4, 5, 8, 34; civilising influence of, 28,137

Hinduism in Bali, 362-3 
Historical sketch, $\mathrm{I}-24$

Holland, area and population, 25 ; Asiatic possessions, 25-6

Houtman, Cornelius, discovers route to India, 15,28

Huns, the, 4

Hunting, I I3

IMPORTS, 253

Indonesians, 33

Industries, native, II2 ; copra, 216 ; bamboo huts, 217 ; sugar, 2248 ; tobacco, 228-3I ; batik- and krees-making, 244 ; silk, 245

Islam, 28 ; introduction of, 137 , I4I

JAPANESE, the, I34; position in the Far East, I55, 166, 369

Java, history, I-24; area, 26 ; population, 27 ; geography, 4553 ; see Crops, Fisheries, Fauna

Javanese, the, in early times, 4,34 , IOI-35; their villages and agricultural pursuits, I05; houses, ro6; customs, ro8; family, ro9; marriage, IIO-II ; crops, III ; industries, II2 ; as workers, II3 ; their fisheries, II3-I8 ; industries, 1 20-5; dress, I23-5 ; village life, I25-6 ; amusements, I27 ; character and manners, I3I-4; culture, I35; mental abilities, I36-I 53 ; thirst for ideas, $147-5$ I

Javanese language, the, $38-40$, I37

Kalangs, customs of the, IO2

Kawi, ancient Javanese, 137

Kediri, 87, 91

Kedu, 70-1

Koningsplein, Batavia, 61

Korintji, 268

Krakatau, eruption of, 26I

Krawang, 63

Kudus, 68

Kupang, $35^{8}$

LABOUR, compulsory, 207-IO; free, 210

Lampong, Residency of, 289, 292

Lampongs, the, 37-42, 267, 284

Land, old forms of tenure, reformed by Raffles, 19, 208, 212, 247-8
Lebongs, the, 267

Lerne, de, 13

Leyden, Dr., 18

Leyden, University of, 200-I

Lombok, 359-67

Lura (loerah), headman, 195

MACASSAR, 33I

Macassars, the, 326,330

Madiun, Residency of, 86,98 , ro I

Madjapahit, empire of, 9,49

Madura, Residency of, 45, 72

Madurese, the, IO3-4

Magelang, 47

Mahomedan festivals, I4I-2. See Islam

Malang, 94

Malaria, of Tjilatjap, 46

Malay Archipelago, formation of, I-2 ; population 26

Malay language, $38-42$; low Malay, 40

Malays, probable origin of, 2-7 ; extraneous influences, 4 ; early legends, 4-33 ; elements of admixture, 34; appearance and qualities, $35-6$, IOI-3 ; of Sumatra, 266; of Menangkabau, 268-9, 270

Mantri, the, 195

Marching-cry of nomads, 5

Mataram, ancient empire of, 74

Mecca, 157

Meester Cornelis, 59

Menado, 334-5

Menangkabau, Malays of, 34, 268-9

Merapi, 69, 7I

Merauke, 356

Merbabu, 69, 7I

Mines and minerals, 242-3; in Sumatra, 297 ; in Banka, 300-1 ; in Borneo, 321

Minto, Lord, 18

Miscegenation, advantages and drawbacks of, $186-8$

Modjokerto, 90

Moluccas, the, 339, 345-9

Money, 252

Mongols, the, 4

Multatuli (E. Douwes Dekker), I6

Nassau, House of, 31

Native languages, $37-42$

"Native Question," the, 203 
Native races, 33-7, and under headings of various islands

Negritos, 33

New Guinea, Residency of, 35I

Niassais, the, $277-8$

Nomadic origin of Malays, legendary and probable, 6

Officials, Colonial, i89-203 ; examinations, 201 ; appointment, 202

Opium, abuse of, $36-7$

Orang Benua, 280

Orang-Ulu, 268

Orang Luba, 268

Orientals, see Foreigners

Outer Possessions, 27, 257

Pacific Continent, the submerged, 2

Pacific Islands, 2

Padang, 287, 289, 290

Padris, the, 287

Pajajaram, empire of, 9

Palembang, 285, 289, 292 ; petroleum in, 302

Pamekasan, 98

Pandopo, the, 106

Pangeran Adipati Mangku Negoro, 75, 79, 8I

Pangeran Adipati Paku Alam, 75, $79,8 \mathrm{I}$

Papua, see New Guinea

Papuans, 33

Pasangrahan, Government inn, 73

Pasuruan, 87, 92

Pekalongan, 65-6

Perkeniers, of Banka, the, 345

Petroleum, 243, 302

Philip II., annexes Portugal, 14, 29

Philologists, official, I97-8

Plantations and plantation life, I73; land tenure, I74; houses, I75-6; see Colonists

Polynesia, 2

Polos, the, 2

Pontianak, 3I8-19

Portugal, discovery of Indies by, 28

Portuguese, discoveries and arrival of, I I-I3

Posts and telegraphs, 25I

Prambanan, 83
Preangers, Residency of the, 64

Principalities, the, see Vorstenlanden

Pringitan, the, 106

Probolinggo, 93

Products, natural and other, 20439

Property, native system of, 212

Protection, 253

Purworedjo, 7I

Puwokarta, 63

QUININE, 233-5

Races, Native, 33-7

Raffles, Sir Stamford, 3, 17 ; Imperial and local policy of, 18 ; reforms, I9, I90; policy of, I9I, 29I

Railways, 249-50, 305-6

Raksha, Hindu demons, 4, 97

Rasaksa, Hindu demons, also name given to pre-Brahmin inhabitants of Java, 4, 6

Redjangs, the, 208

Regents, native, 193

Rembang, 85

Residencies of Java, 57-100 ; of Sumatra, 289

Residents, the, 194, 197

Revenue, 19

Rice, 213-16

Riouw Lingga, Archipelago of, 278-80, 296

Rivers of Java, 50-I

Roads, 249

Rubber, 300

Rulers, Native, roo ; pensions and salaries of, I93 ; titles, I93

Russo-Japanese War, effect of, $7,154-5,364$

Sá Francisco de, I3

Salatiga, 68

Salejer, 333

Salt, 244

Samarang, port of, 66 ; suburbs, 67

Sampang, 99

Sandal-wood Island, $35^{8}$

Sarong, the, I23

Sasaks, the, 364

Schools, I49-153

Sclo mangling (native Hindu shrines), 9I 
Serdang, 294-5

Shipping, 25I-6

Shiva, worship of, 96

Sindow, 7I

Sirih (betel), 107

Sitabondo, $97-8$

Slamettan, or banquet, I3I, I4I

Slavery, suppressed, I7I

Snakes, 46

Solo River, 86-7

Solor Islands, 357

State philologists, 197

Sugar, 224-8

Sukabumi, 64-5

Sultan, the, 75-6, 82-3

Sumatra, 257; climate, 259; volcanoes, 259-262 ; rivers, 262 ; climate, 265 ; flora and fauna, 265-6 ; inhabitants, $265-278$; languages, 282 ; history, 285-8 ; Residencies of, 289; minerals, 297 ; crops, 303-4 ; railways, 305

Sumatra, East Coast, 292, 294

Sumatra, West Coast, 306

Sumba, $35^{8}$

Sumbawa, $35^{8}$

Sumbing, $7 \mathbf{I}$

Sundanese, the, $34-5$, IOI-3

Surabaja, 87-90

Surakarta, 78,82

Susuhunan, the, $74-7,80-1$

Tandjong Priok, port of Batavia, 59-60

Tandjong Priok, capital of Riouw Lingga archipelago, 296

Tapanuli, 289, 29I

Tea, 23I-3

Teak, 240-2
Tenggris, the, 96

Ternate, 347

Tigers, 56

Timber, 240-2, 300

Timor, 3I, 353; Holland's endeavour to purchase, $388-9$

Tjandi Loro, 64

Tjandi Mendut, 83

Tjandi Sewu, 84

Tjilatjap, 69 ; malaria of, 70

Tobacco, 228-3I

Tondano, 335

Toradjas, the, 329

Tosari, sanatorium, 95

Trade, 253-4

Trading companies, 15

Tumpang, 97

VAN DEN BOSCH, system of cultivation, $207-8$

Vall den Lith, 209

Van Hoëvell, 209

Van Putte, 209

Vegetation, Javanese, 53-4

Venetians, 28

Veth, 219

Volcanoes, 32, 48-50

Vorstenlanden, 57 ; railway, 66 ; history, $74-6$; produce, $77-85$

WAR with England, I70; with France, I7 I

Waingapu, 359

Wayang, 127-130

Wedono, 195

Weltevreden, 59-60

Willoughby, attempts North. Eastern passage, 14

Wong Madjapahit, $36 \mathrm{I}$ 


\section{ROTTERDAM LLOYD \\ ROYAL MAIL LINE.}

The Direct Route to Sumatra and Fava

Fortnightly Passenger Service of Mail Steamers

Rotterdam and Southampton

Via LISBON, TANGIER, GIBRALTAR and MARSEILLES to EGYPT, CEYLON, SUMATRA and JAVA, and vice versa

Modern Steamers fitted with every comfort for

Eastern Travel; Excellent Cuisine; Single-berth

Rooms ; Marconi's Wireless and Submarine Signalling; Electric Laundries, \&c., \&c.

Through Tickets to all Ports in EAST INDIAN ARCHIPELAGO and to AUSTRALIA, STRAITS, CHINA, JAPAN, \&c., in connection with Regular Services of the Royal Packet S.N. Co. (K.P.M.)

\section{ROUND THE WORLD TOURS}

affording passengers an opportunity of making the trip from Padang to the magnificent Padang Highlands by one of the most interesting railroads in the world, and for Tours in the Island of Java APPLY FOR DESCRIPTIVE BOOKLETS

$A N$ IDEAL SIX WEEKS" TOUR COLOMBO, PADANG, BATAVIA, SINGAPORE, SABANG, COLOMBO

Commencing at any point in circle, ending at same point, in either direction, allowing break of journey and available six weeks

Tickets issued throughout the year at-1st class, £22 10s. ; 2nd Class, £16

SHORT SEA TRIPS IN THE MEDITERRANEAN.-The Company issue Tourist Tickets - all Sea, or combined Sea and Rail - throughout the year, at low fares. Ask for Handbook, and Descriptive Booklet.

Principal \{ ROTTERDAM : RUYS \& CO. (General Agents), 7 Veerhaven.

Agents.. $\{$ LONDON (Great Britain): ESCOMBE, McGRATH \& CO., 3 East India Avenue. and at Southampton, Glasgow, Manchester, Liverpool, Birmingham. Grimsby and Middlesbrough. London West End Agency : SEWELL \& CROWTHER, 21 Cockspur Street.

LISBON: E. George Succs., 8 Rua Bella da Rainha. TANGIER: Joel Lalaurie, Plage.

GIBRALTAR: London Coal Company.

PORT SAID, SUez: Port Said and Suez Coal Co., Ltd. COLOMBO: Aitken, Spence \& Co.

MARSEllzeS, Ruys \& Co., 5 Boulevard Dugommier.

BATAVIA, SAMARANG, SOURABAYA, Internationale Crediet and Handelsvereeniging, Rotterdam.

And all Offices of ROYAL PACKET S.M. CO. (K.P.M.), THOS. COOK \& SON, and Touplst Agencios 


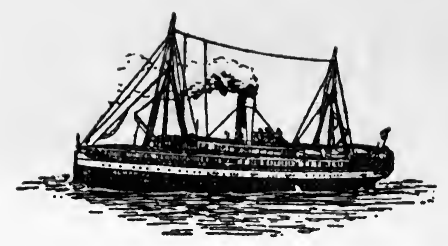

\section{Koninklyke Paketvaart Maatschappi]}

(Royal Packet Steam Navigation Company).

Royal Mail Service, under contract with the NetherlandsIndian Government between Singapore, Penang, and the principal Ports of the Netherlands-India-Archipelago, the loveliest Island scenery in the world.

Up-to-date Ist and and class passenger accommodation. All steamers are fitted with electric light, several with refrigerating plant, fans, \&c.

Numerous services carried on by a fleet of

54 Modern passenger Steamers specially built for the tropics 16 well-equipped cargo steamers, and

4 Stern-wheelers for river service.

By means of 46 regular services, 259 ports throughout the Netherlands-India Archipelago are connected with the outer world.

Monthly service from Java to Australian Ports as far as Melbourne, and vice versa.

Connection at Singapore with the mail steamers of the principal Steamship Companies.

For further particulars and time-table please apply to the Company's Head Office at Amsterdam, or to the Chief Agency at Batavia. Also at the Company's Agencies. 


\section{NEDERLAND ROYAL MAIL LINE}

(8toomvaart Maatechappi] Nederland).

This Company maintains Regular Fortnightly Mail Services from

\section{AMSTERDAM and SOUTHAMPTON}

Lisbon, Tangiers, Algiers, and Genoa to

EGYPT

SINGAPORE COLOMBO

SOURABAYA.

Connecting in SINGAPORE with Steamers for

SAIGON

CHINA
BANGKOK

and
SABANG

SAMARANG
BATAVIA

MANILA

JAPAN

Transshipment at BATAVIA for ports in Australasia.

Through tickets also issued to all ports in the Netherlands Indian Archipelago.

The steamers are first-class in every respect; fitted with Marconi Wireless Equipment, also submarine signals, and are recognised amongst the best-equipped liners sailing to the East. The comfortable passenger accommodation affords spacious cabins and many single berth rooms. The company's service and cuisine are unsurpassed.

The new twin-screw steamer Prinses Juliana ( 8,300 tons) which was launched in 1910 by Queen Wilhelmina, took her first sailing in October, 1910, and has proved a phenomenal success, being highly popular with travellers to the East. Another large twin-screw steamer will be launched in $191 \mathrm{I}$, and the fleet will be strengthened by other equally fine vessels adapted for the better class traffic between Europe and the Dutch East Indies.

\section{Delightful and Cheap Mediterranean Trips between Southampton and Genoa.}

\section{Round the World (via Java) Tours.}

For Full Particulars, Handbooks, and Fares, apply to the Head Offices of the Company, PRINS HENDRIKKADE, I59-160, Amsterdam; or in London to

\section{H. V. ELKINS, General Passenger Agent, 60 Haymarket, London, S.W.}




\section{THE SOUTH AMERICAN SERIES}

\section{Vol. I.-CHILE.}

By G. F. SCOTT ELLIOT, M.A., F.R.G.S., Author of "A Naturalist in Mid-Africa." With an Introduction by MARTIN HUME, a Map and 39 Illustrations.

"An exhaustive and interesting account, not only of the turbulent history of this country, but of the present conditions and seeming prospects, . . . and the characters of the Chileno and English and German colonists there."- Westminster Gazette.

\section{Vol. II.-PERU.}

By C. REGINALD ENOCK, F.R.G.S., Author of "The Andes and the Amazon." With an Introduction by MARTIN HUME, a Map and 72 Illustrations.

"An important work. . . . The writer possesses a quick eye and a keen intelligence ; is manysided in his interests, and on certain subjects speaks as an expert. The volume deals fully with the development of the country. . . . Illustrated by a large number of excellent photographs." -The Times.

\section{Vol. III.-MEXICO.}

By C. REGINALD ENOCK, F.R.G.S. With an Introduction by MARTIN HUME, a Map and 64 full-page Illustrations.

"Mr. Enock unites to a terse and vivid literary style the commercial instinct and trained observation of a shrewd man of affairs."-Aberdeen Free Press.

"Mr. Enock transmutes the hard material of ancient chronicles into gleaming romance ; he describes scenery with a poet's skill. Full of charm he makes his pages, alluring as a fairy tale, an epic stirring and virile."-Manchester City News.

\section{Vol. IV.-ARGENTINA.}

By W. A. HIRST. With an Introduction by MARTIN HUME, a Map and 64 Illustrations.

"The best and most comprehensive of recent works on the greatest and most progressive of the Republics of South America."-Manchester Guardian.

"A very interesting and trustworthy survey of the present conditions and prospects of the country."-Times.

\section{Vol. V.-BRAZIL.}

By PIERRE DENIS. With a Map and 36 Illustrations.

"It is a mine of information, arranged with all the lucidity of a Frenchman ; and in one case, in the long chapter devoted to the valorisation of coffee, the treatment deserves to be called masterly."-Globe.

\section{Vol. VI.-URUGUAY.}

By W. H. KOEBEL. With a Map and 55 Illustrations.

- "An expert's diagnosis of the present condition of Uruguay. . . . A document of the deepest interest."-Evening Standard. 


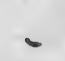$$
\text { - }
$$
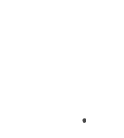

\section{.}

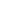





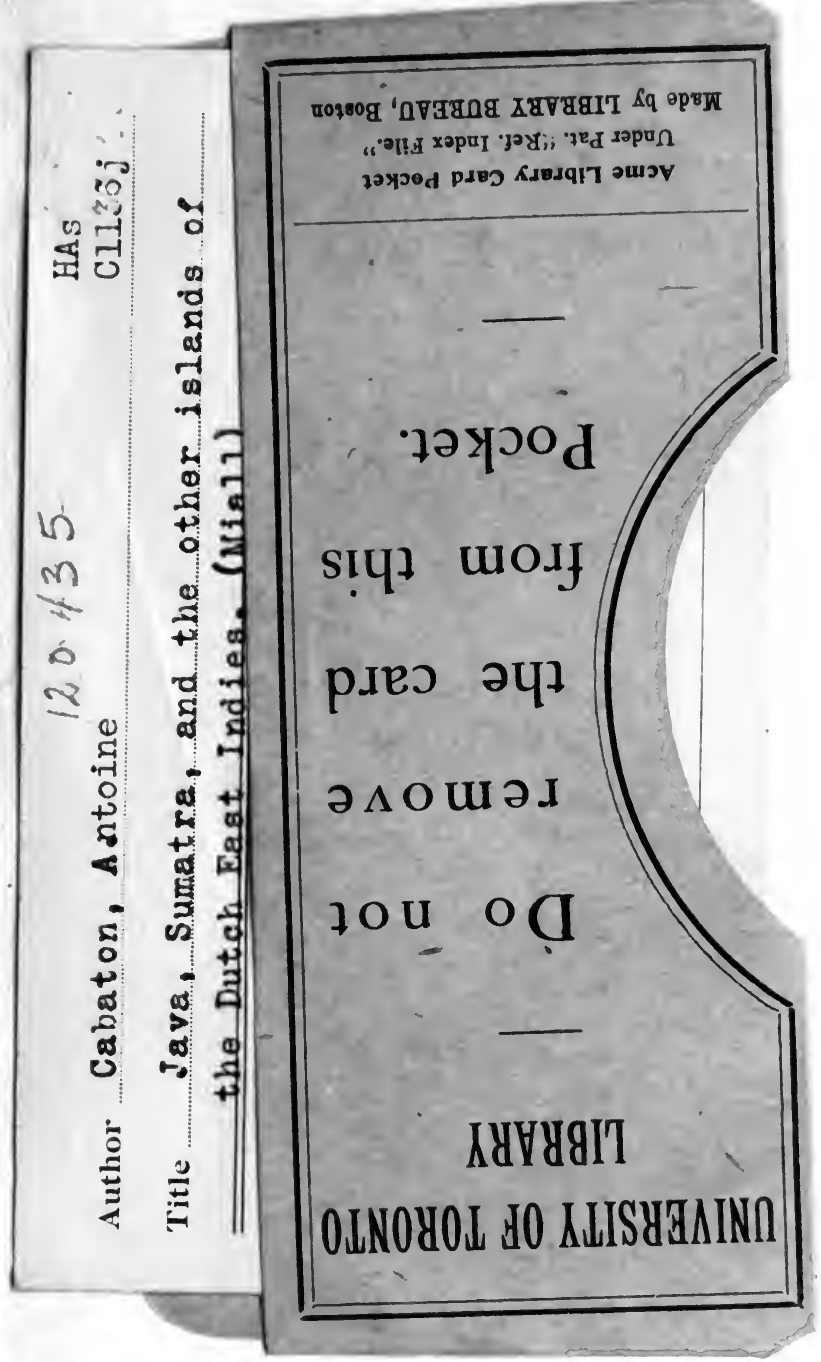


